\title{
Great Expectations: what shareholders and directors expect from New Zealand public company boards.
}

by

David Ware

A thesis submitted to the Victoria University of Wellington in fulfilment of the requirements for the degree of Doctor of Philosophy

Victoria University of Wellington

2016 


\section{Abstract}

One of the key roles of corporate boards is to decide how the cash generated by these companies is distributed, and through these decisions they influence the wealth of many in our society. But beyond this task what is expected of corporate boards? Although researchers have spent decades examining boards, a general consensus regarding the objectives and tasks that they should perform has yet to emerge. Using a combination of primary and secondary research, this study examines the expectations that shareholders and directors have of corporate boards in New Zealand and identifies some concordance between their views and some of the extant literature. These findings highlight the contingent nature of corporate governance and provide guidance to both practitioners and future researchers.

New Zealand public companies were selected for this study because their directors and shareholders remain open to sharing their views and experiences with external researchers. New Zealand uses a straightforward variant of the common Anglo-Saxon corporate governance model so there is some potential to generalise to other contexts. Developing the foundation for this research required refreshing and extending the extant research concerning aspects of the NZ commercial environment including company ownership and control, shareholder and director demographics, and the underlying commercial environment. Subsequently, a mixed methods approach was adopted for the core study which included conducting focus groups and surveys with both shareholders and directors. Data were also derived from secondary sources including, company annual shareholder meeting minutes, the Companies Office's records and the social media website Linkedin.

The research finds that while both directors' and shareholders' expectations of boards are broadly aligned, the expectations that both groups have of boards are heterogeneous in 
some key respects. Interestingly, the diversity of opinion that appears to exist within each of these groups tends to reflect the diversity that is apparent within the governance literature. Socio-economic factors including the influence of 'women on boards' lobby groups and company specific environmental factors such as a company's financial position were identified as some of the influences which contribute to this diversity of opinion.

Environmental factors not only appear to influence the opinions of directors and shareholders but also appear to influence other aspects of corporate governance such as the selection of directors, and the tasks that boards choose to perform. This suggests that a pragmatic rather than a doctrinal basis for this heterogeneity is applicable. So rather than boards adhering to a specific pre-established framework such as 'shareholder advocate' or 'company controller,' corporate boards appear willing to adjust their objectives and practices to meet the circumstances at hand. For researchers, these findings emphasise the importance of considering contextual factors when designing corporate governance research projects. They also highlight the importance of understanding stakeholder motivations when applying common governance theories. From a policy perspective, the findings reinforce the advantages of the 'comply or explain' approach to regulation and they add caution to making local and international best practice guidelines mandatory. 


\section{Acknowledgements}

This thesis has been a journey. Like any journey it's the unplanned, unscheduled, random bits that make the trip worthwhile - such as the thrill of 'rediscovering' the 1844 Joint Stock Act; or when, after hours and days and months, the dots would finally join and I'd discover something unique - eureka! - but it was only ever a moment, and, when it passed, that 'discovery' suddenly seemed so simple .... and so obvious. But that's what I love about research.

Umberto Eco knows about these things; he claims that a first thesis is like your first true love. Maybe. For me it's all been about the journey. But on this Eco and I agree: it is an experience to be cherished forever.

And my supervisors. Turning to Eco again, he says their role is to provoke the student into developing new ideas. Urs and Sally, you did all of that and so, so much more. Thank you both for your tolerance, and for your speed and professionalism.

Belinda thank you for indulging me, and thank you for your forbearance

Amelia, Madeline and Ben - this one is for you. 


\section{CONTENTS}

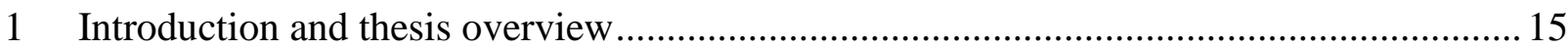

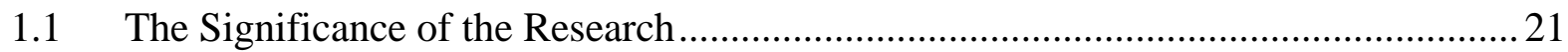

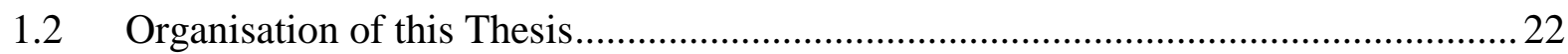

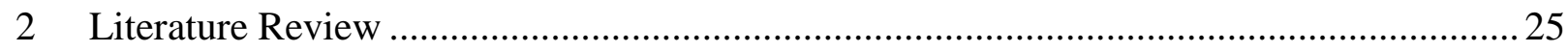

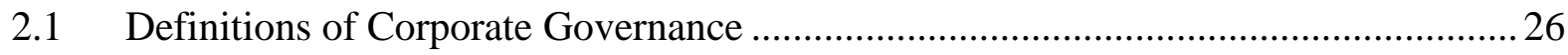

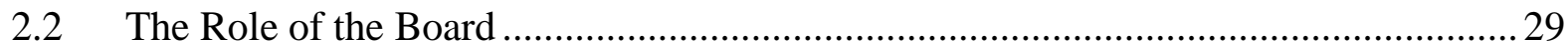

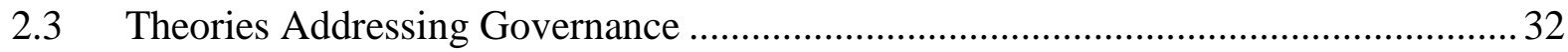

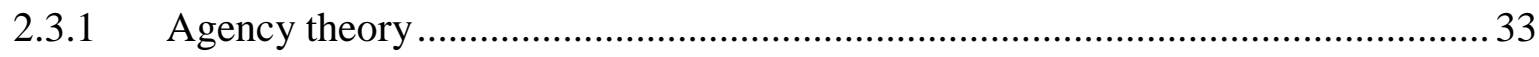

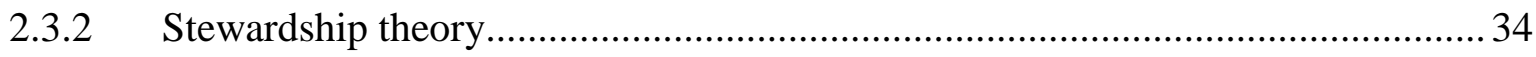

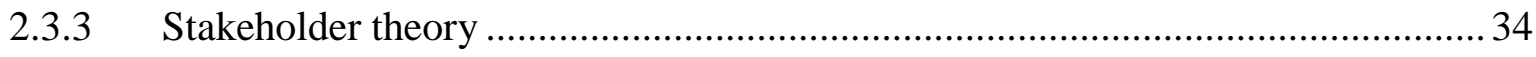

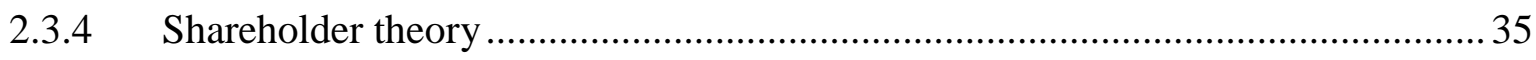

2.3.5 Summary of theories addressing governance ................................................. 35

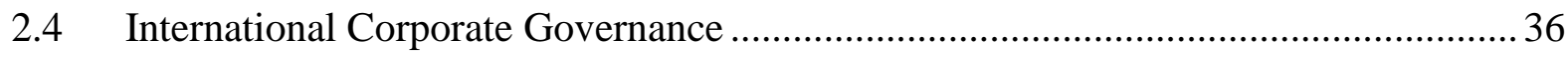

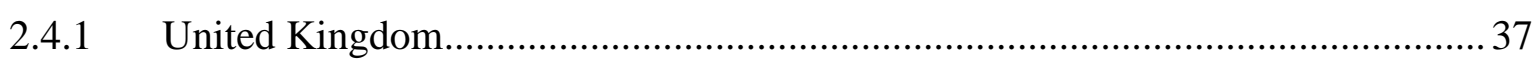

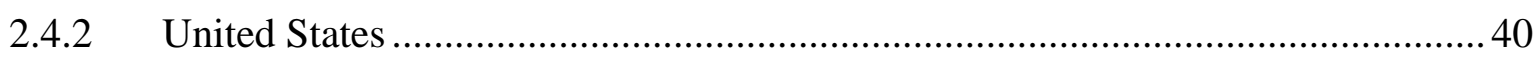

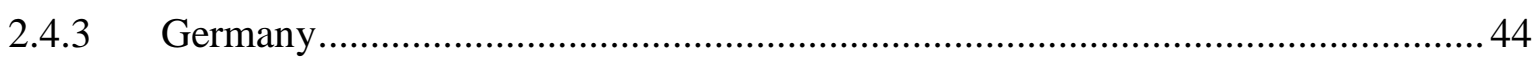

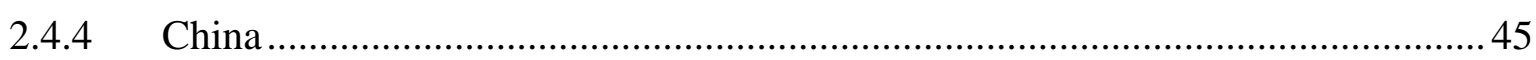

2.4.5 Summary of international corporate governance models ....................................4 47

2.5 Empirical Measures of Boards and the Implications for Stakeholder Expectations .... 48

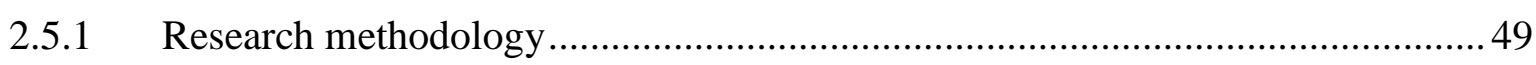

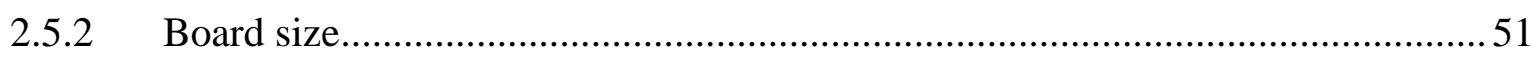

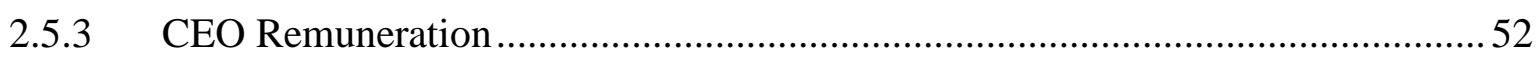

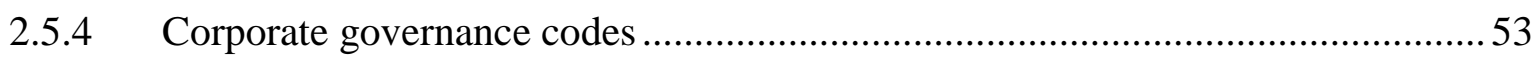

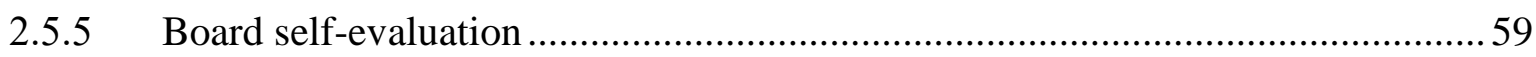

2.5.6 External corporate governance rating systems …............................................ 60

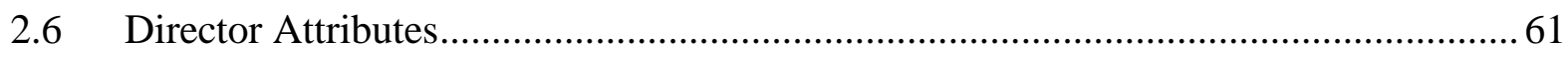

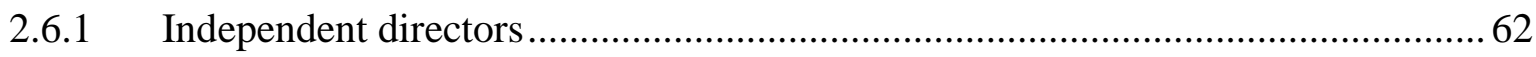

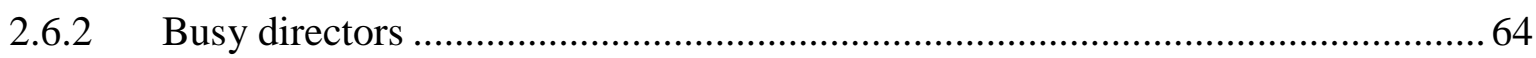

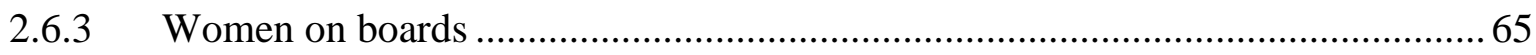

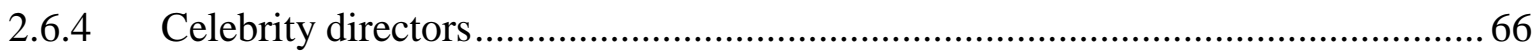

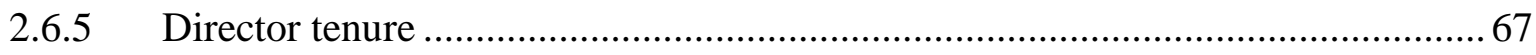

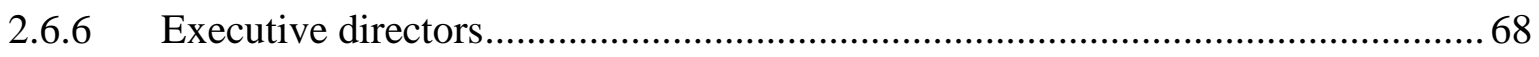

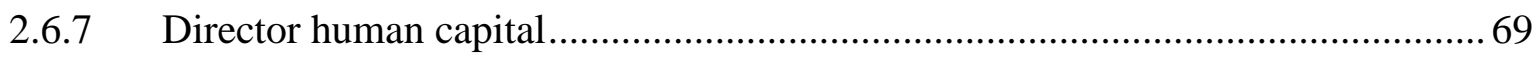




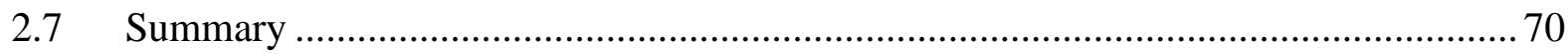

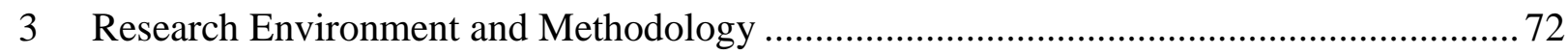

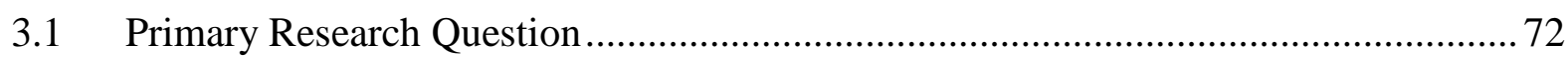

3.2 Addressing the Traditional Corporate Governance Research Limitations.................. 74

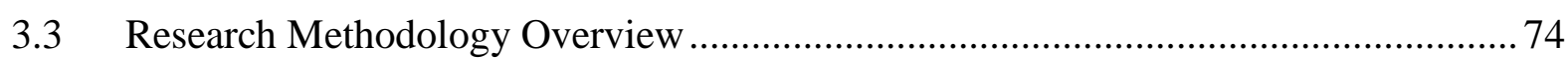

3.4 Director, Shareholder and Environmental Influences on the Research Methodology. 77

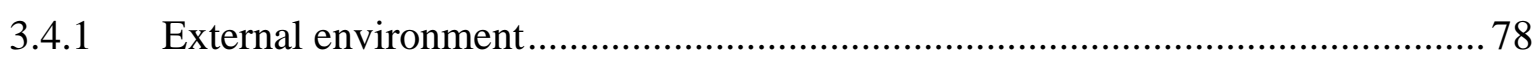

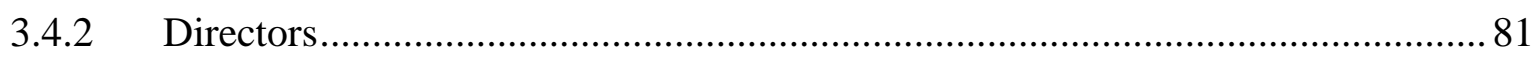

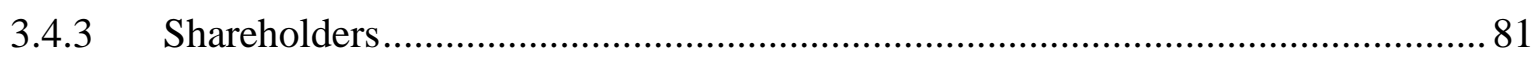

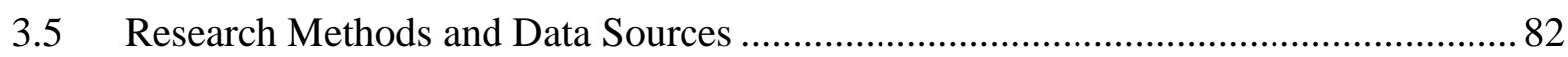

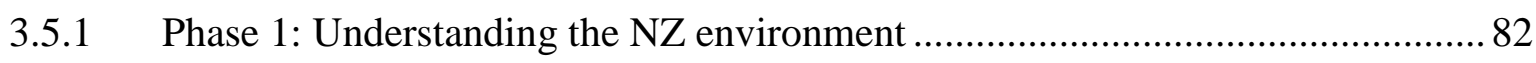

3.5.2 Phase 2: Director and shareholder focus groups ................................................ 88

3.5.3 Phase 3: Annual shareholder meeting minutes analysis ..................................... 90

3.5.4 Phase 4: Director and shareholder surveys ...................................................... 92

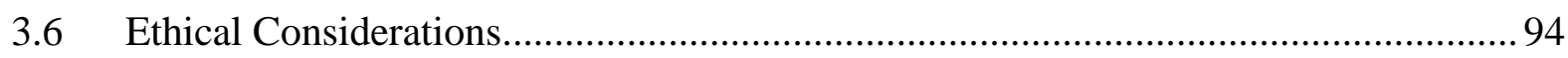

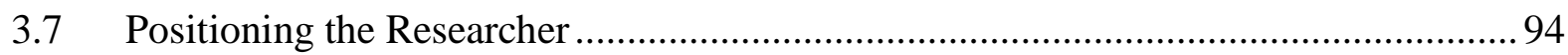

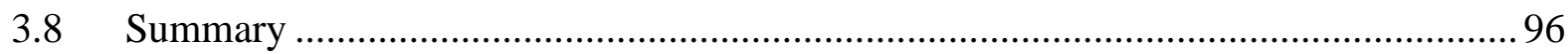

4 The NZ Corporate Governance Environment ............................................................ 98

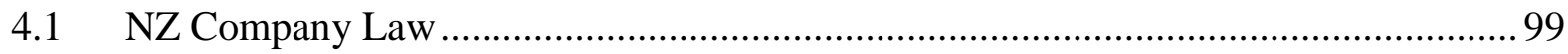

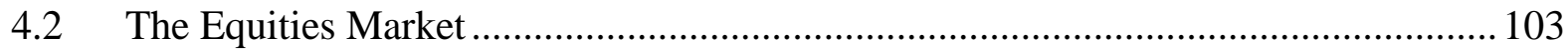

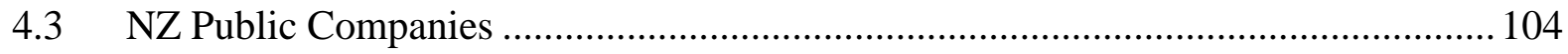

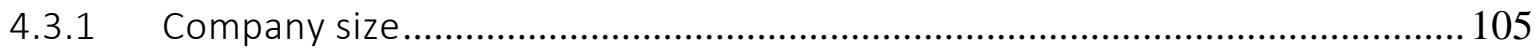

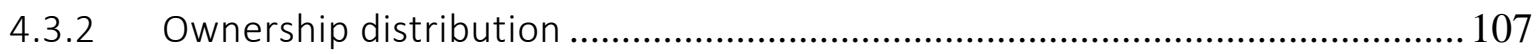

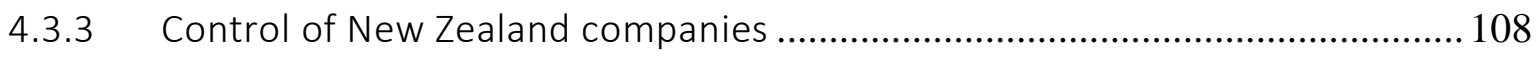

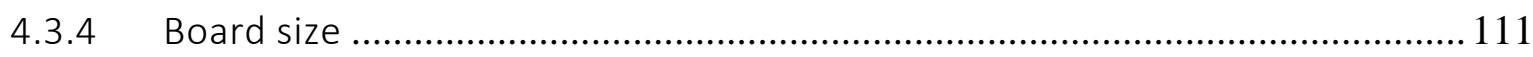

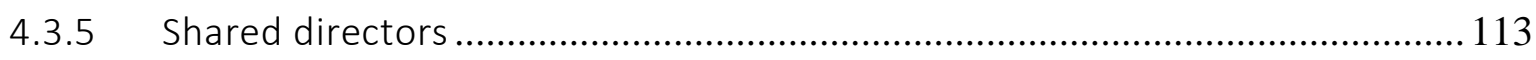

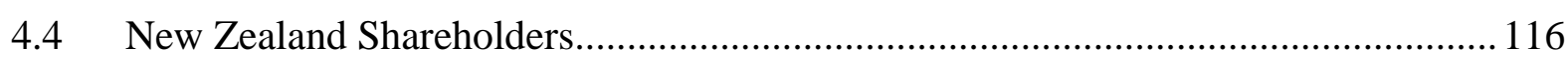

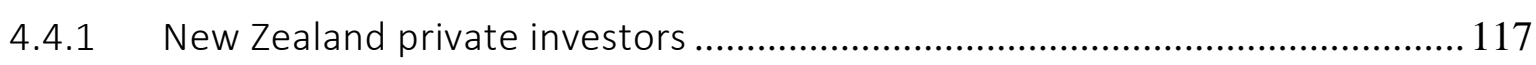

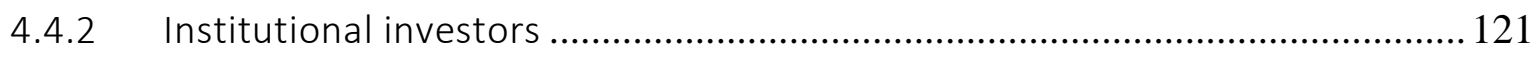

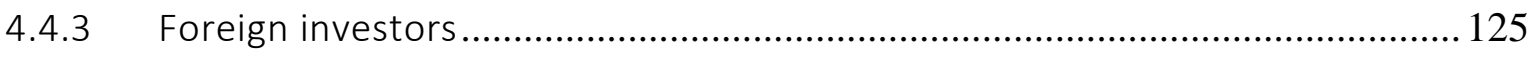

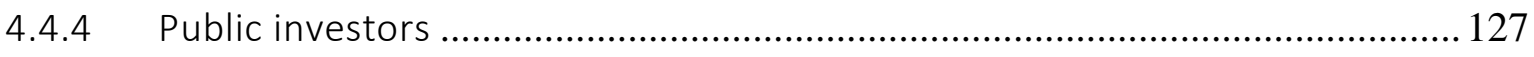

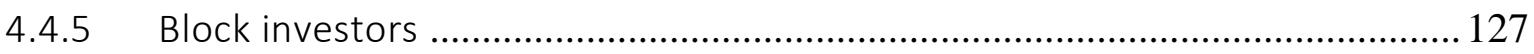

4.5 New Zealand Company Directors ...................................................................... 129

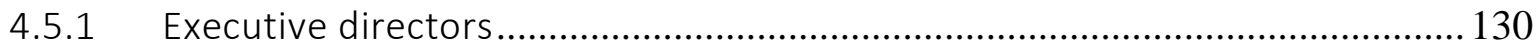

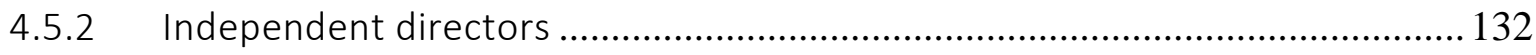




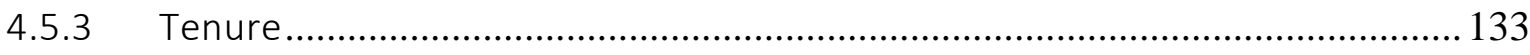

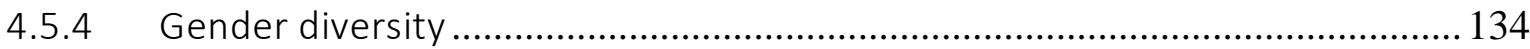

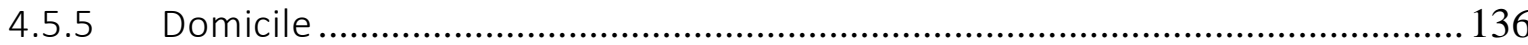

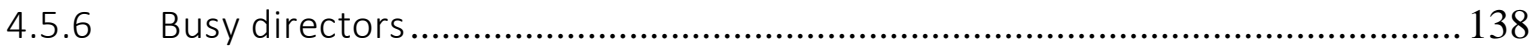

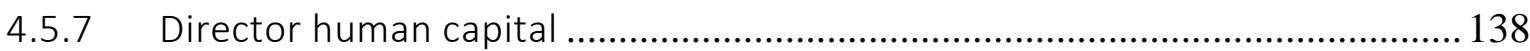

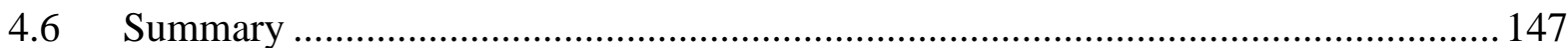

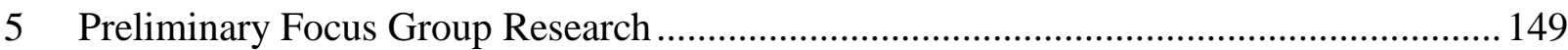

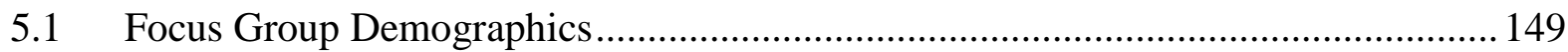

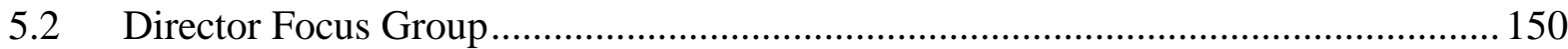

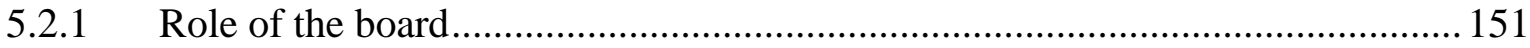

5.2.2 The relationship of the board with shareholders ............................................ 154

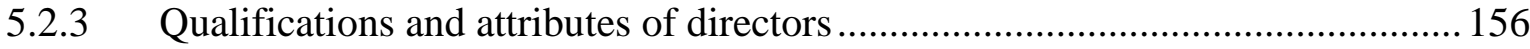

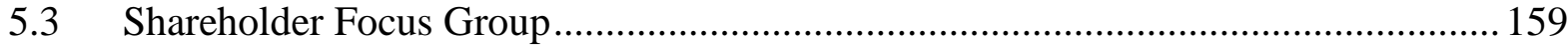

5.3.1 The importance of the board to shareholders................................................... 159

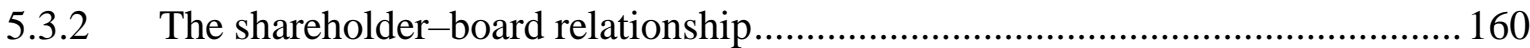

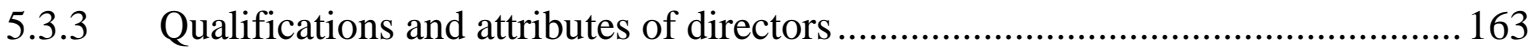

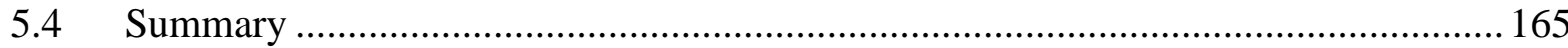

6 Analysis of Annual Shareholders' meeting Minutes ...................................................... 169

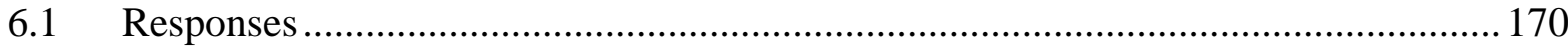

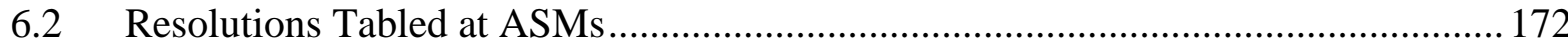

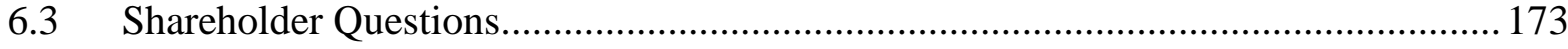

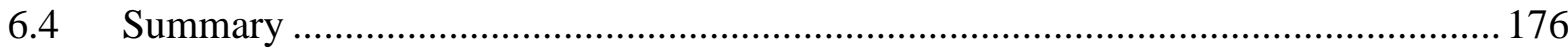

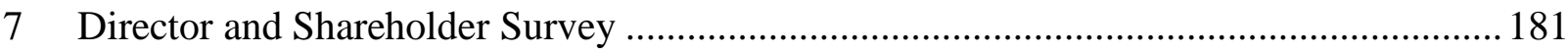

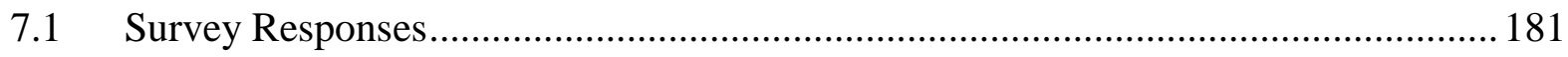

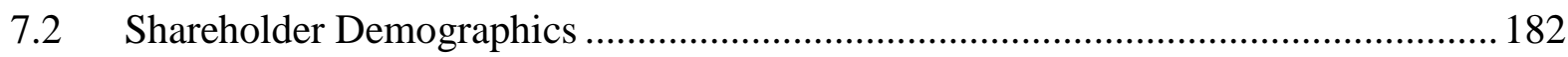

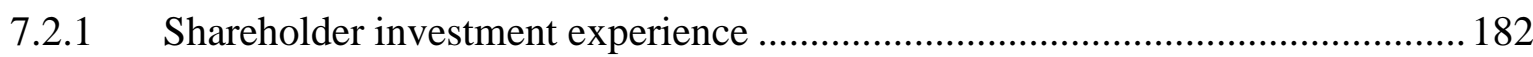

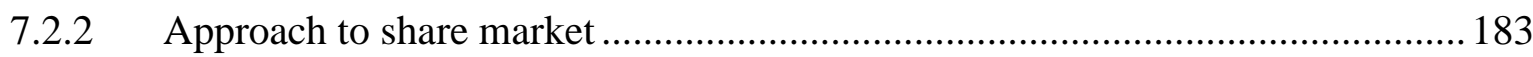

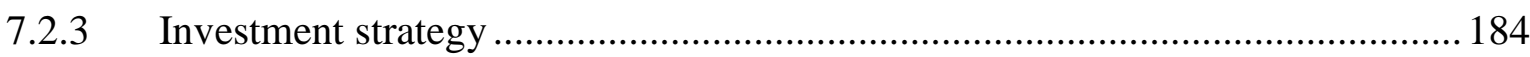

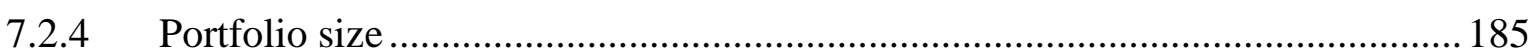

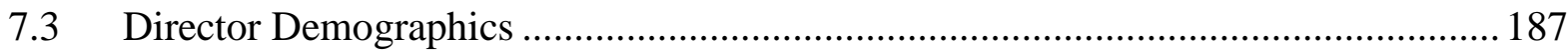

7.4 Directors and Shareholders' Opinions of Each Other ............................................. 187

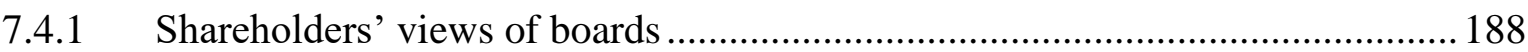

7.4.2 Shareholders' view of directors' performance in crisis .................................... 188

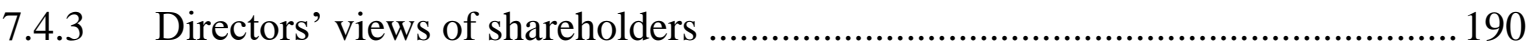

7.4.4 Shareholder and director views on director remuneration ................................ 191 


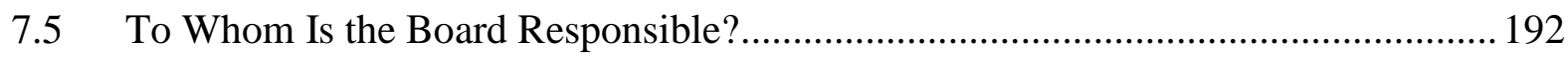

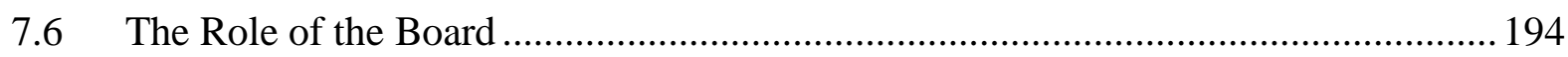

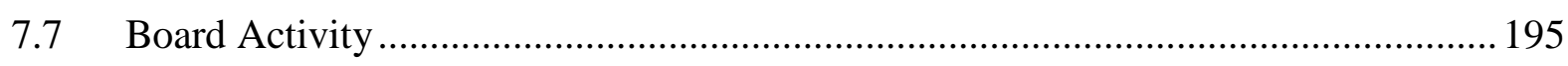

7.7.1 Tasks the board should perform when a company is trading profitably .............195

7.7.2 Tasks the board should perform when a company is under financial stress ....... 198

7.7.3 Changes in stakeholder expectations that occur when a company is under

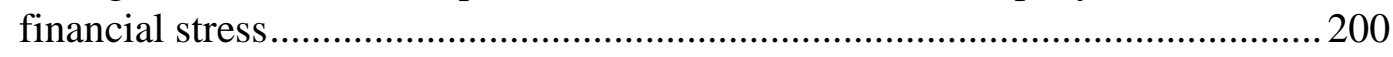

7.8 Board Shareholder Communication ..................................................................... 202

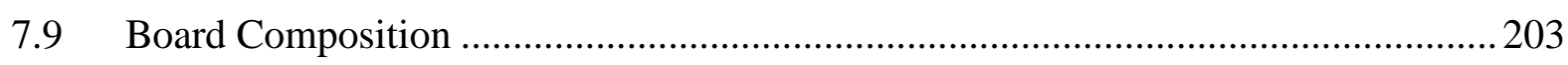

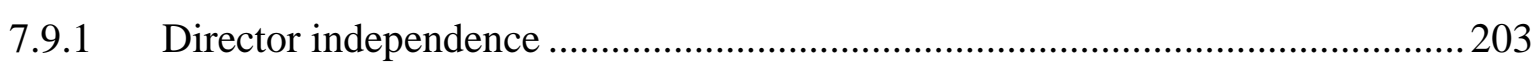

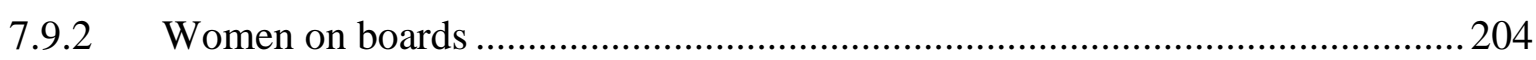

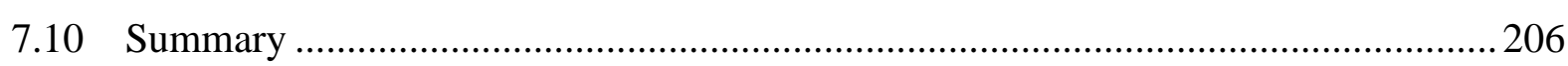

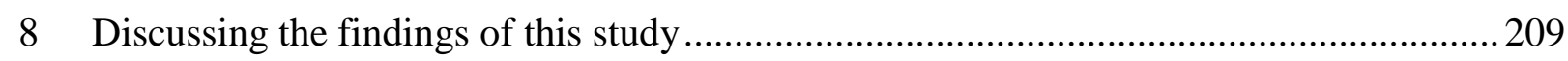

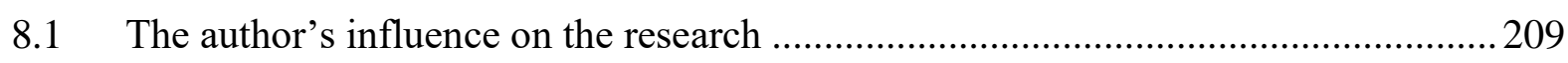

8.2 NZ Public Company Boards and the Environment in Which They Operate ............. 212

8.2.1 The New Zealand approach to corporate governance........................................212

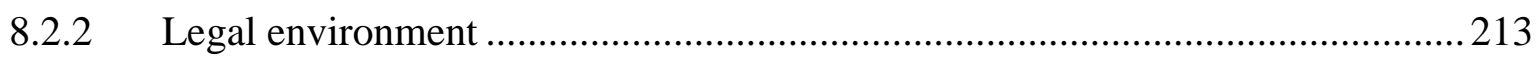

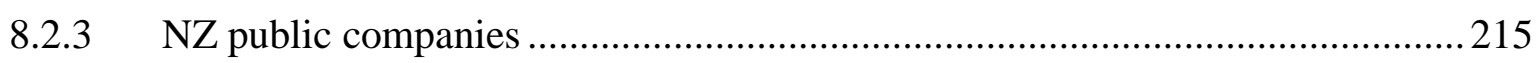

8.2.4 Political and social influences: the appointment of women directors..................216

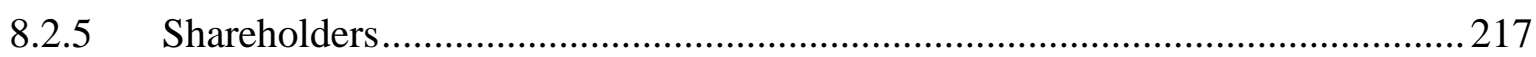

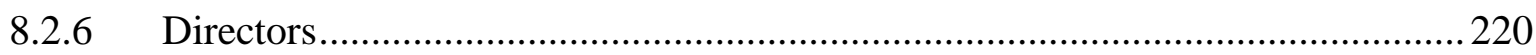

8.3 Director and Shareholder Expectations of Boards ...............................................223

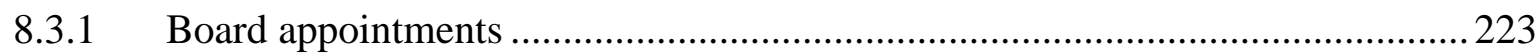

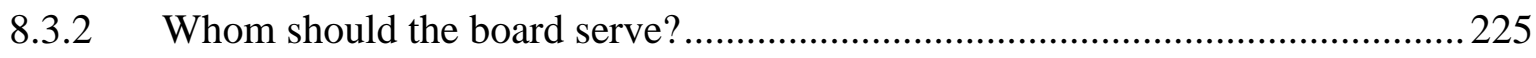

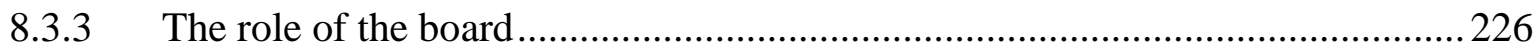

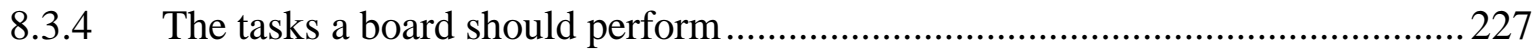

8.3.5 Boards' communication to shareholders..............................................................229

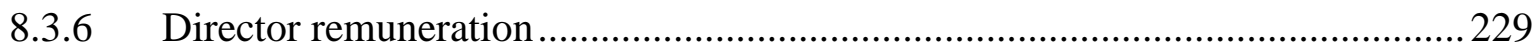

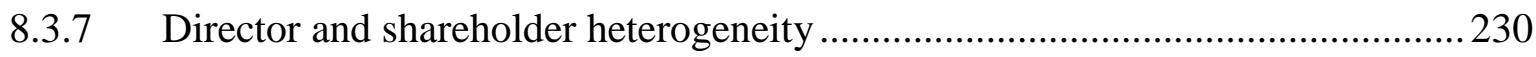

8.3.8 The dynamic nature of board and shareholder expectations ...............................233

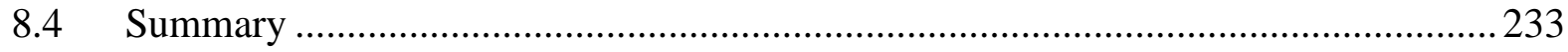

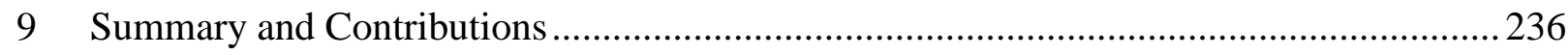

9.1 Key findings and their contribution to the extant literature ...................................236

9.1.1 Contribution to an understanding of the characteristics of New Zealand shareholders, directors and companies 
9.1.2 Acknowledgement of the diversity that exists in shareholders' and directors' expectations of boards and of governance ......................................................239

9.1.3 Highlighting the influence of environment on corporate governance ................239

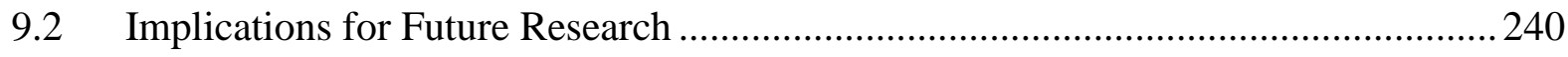

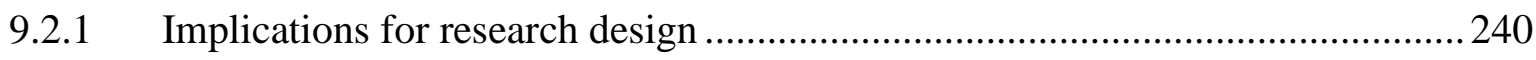

9.2.2 Reflections on popular corporate governance theories .................................... 241

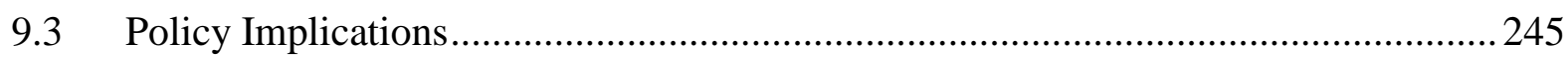

9.3.1 Improving investor confidence in boards ...................................................... 245

9.3.2 Maintaining a ‘comply or explain' approach to regulation ............................... 246

9.3.3 Corporate governance best practices ............................................................ 247

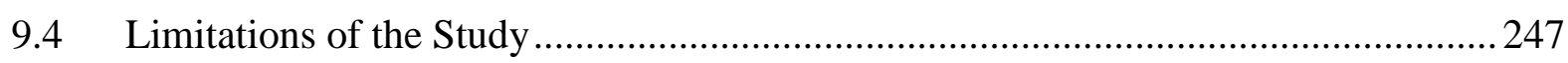

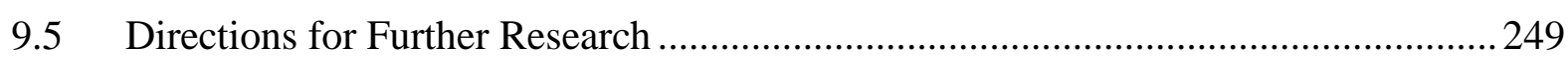

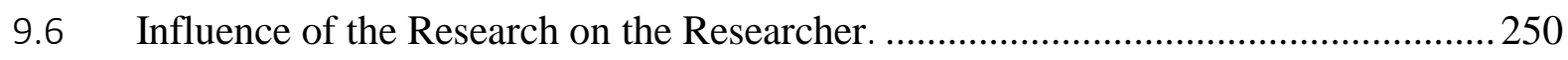

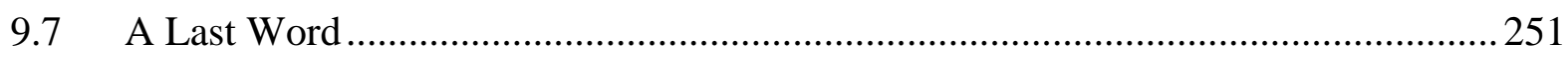

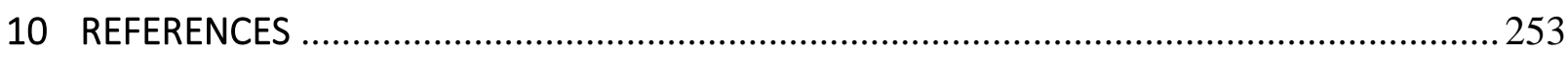

11 Appendix A. Average Time NZSX Shares are Held .................................................... 284

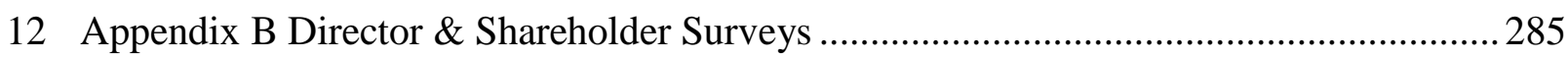

13 Appendix C Directors' and Shareholders' expectations of the tasks a board should perform

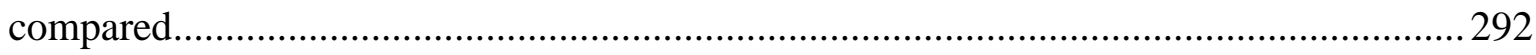

14 Appendix D Changes to Board Activity When Company is under Financial Stress ........294 


\section{TABLE OF TABLES}

Table

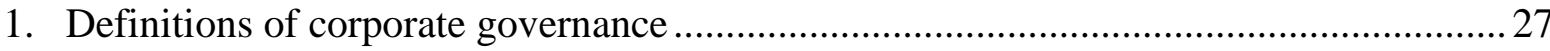

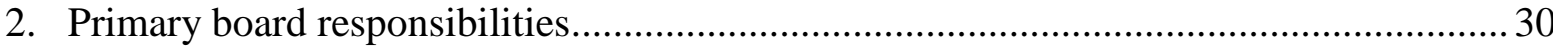

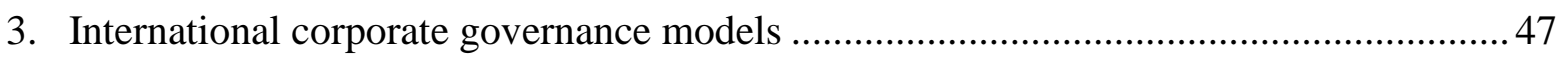

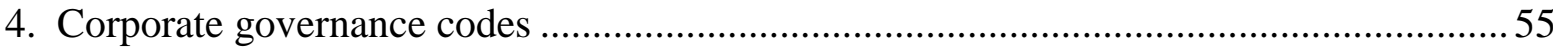

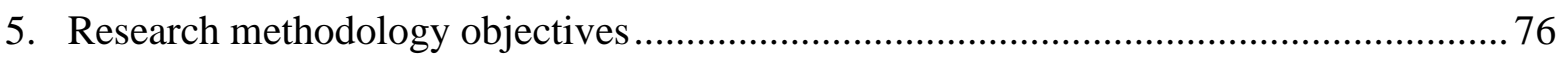

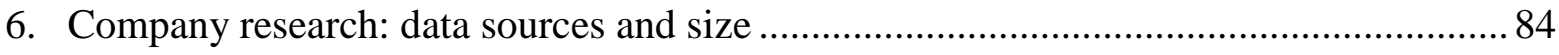

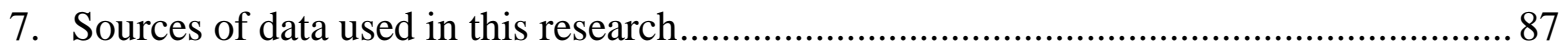

8. Market capitalisation of NZSX-listed companies .................................................. 105

9. Mean market capitalisation of NZSX-listed companies ........................................... 106

10. Distribution of shareholdings in NZSX-listed companies ...................................... 107

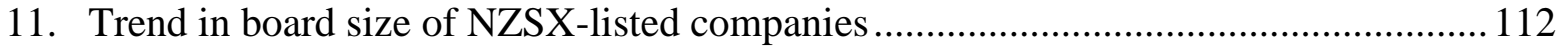

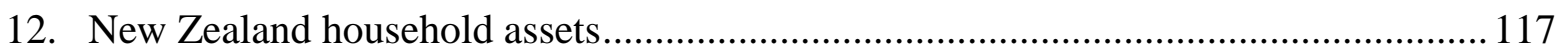

13. Trend in share of adult New Zealanders owning NZ equities.................................. 118

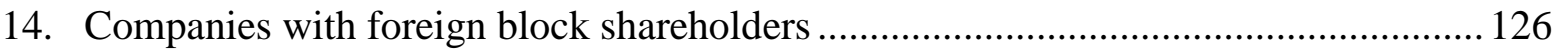

15. Distribution of NZSX block holding shareholders 2013 ....................................... 129

16. Share of executive directors on NZSX-listed company boards ................................. 131

17. Share of independent directors on NZSX-listed company boards ............................. 133

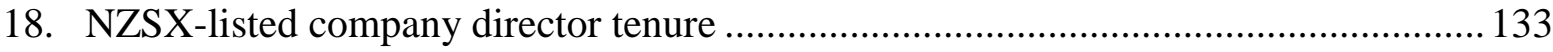

19. Trend in share of NZSX-listed company directors who have served more than 5

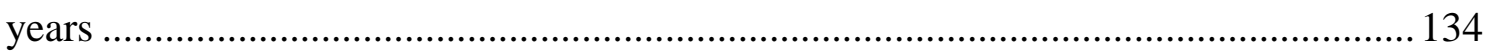

20. Trend in share of female directors of NZSX-listed companies.................................. 136

21. Domicile of directors of NZSX-listed companies 2013 _.......................................... 137

22. Share of NZSX-listed companies with an overseas based director (2013) ................. 137

23. Summary of NZSX directors who sit on multiple boards (2013) ............................. 138

24. 2013 board appointments: directors' human capital attributes ................................. 141

25. Comparison between the expertise of inside and independent directors of NZSX-listed companies

26. Comparison of the expertise of male and female directors of NZSX-listed companies 
Table

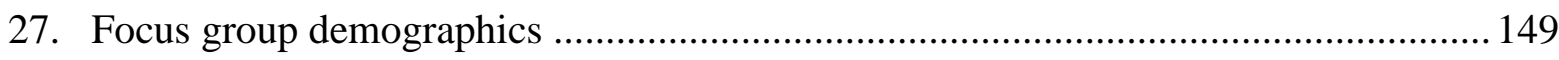

28. Summary of responses to ASM minutes survey …............................................. 170

29. ASM minutes survey respondents compared to a reference sample of companies ..... 171

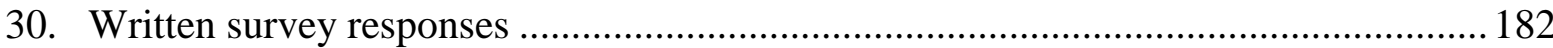

31. Number of years that shareholders have invested in NZX shares.............................. 183

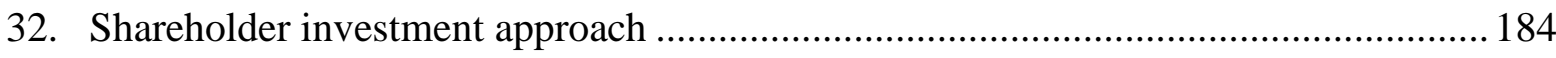

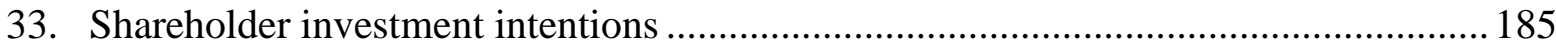

34. Number of companies in a shareholder's portfolio ................................................ 185

35. Years employed as an NZX-listed company director ................................................ 187

36. Shareholder opinions regarding director behaviour during a financial crisis ............. 189

37. Directors' views on how board responsibilities change in a financial crisis ................201

38. Directors of NZSX boards summarised (2013) ........................................................... 221

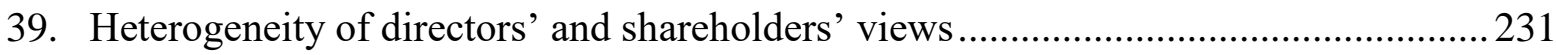

40. Heterogeneity of directors' and shareholders' views continued ...............................232

41. Matching corporate governance theory to ownership structure ..................................244

42. Directors' and shareholder' expectations of the tasks a board should perform when a

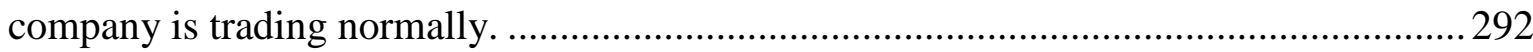

43. Directors' and shareholders' expectations of the tasks a board should perform when a company is under financial stress 293

44. Changes in director expectations based on financial state of corporation ..................294

45. Changes in shareholder expectations based on financial state of corporation .............295 


\section{TABLE OF FIGURES}

Figure

1. Conceptual model of the corporate governance environment........................................ 73

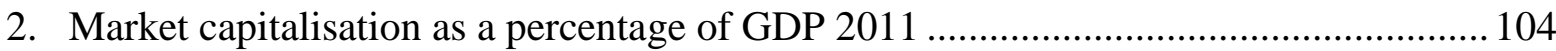

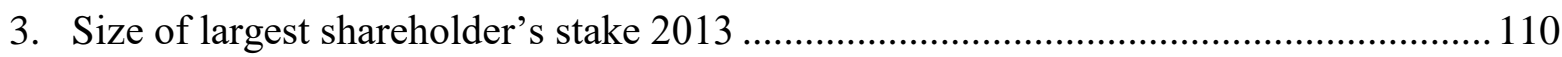

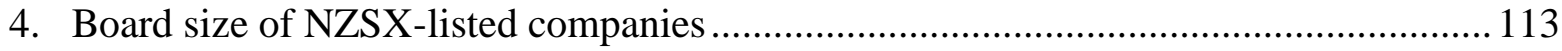

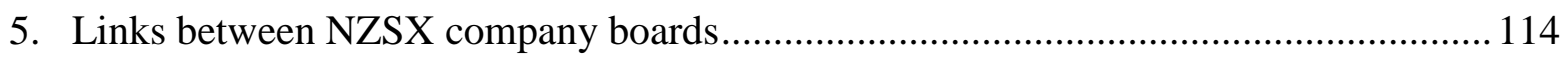

6. Map of board linkages between NZSX companies .................................................. 115

7. Private investment in New Zealand equities .............................................................. 119

8. Share of equities owned by foreign investors ..................................................... 125

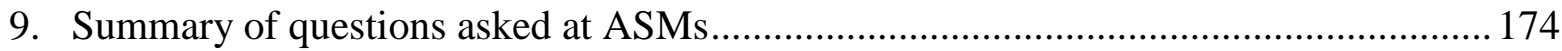

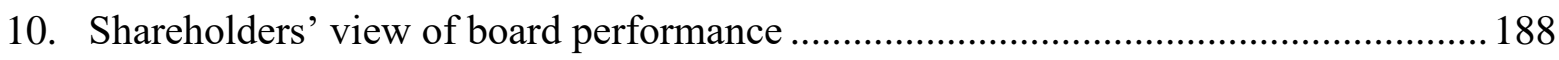

11. Director expectations of company performance ….................................................. 190

12. Shareholder and director views on director remuneration ....................................... 192

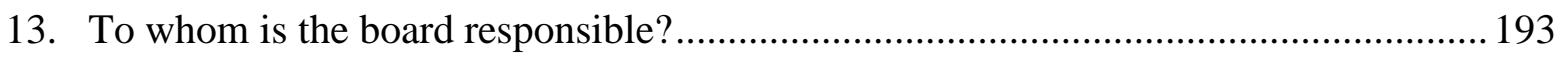

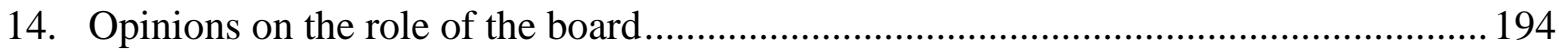

15. Views on board responsibilities when a company is trading normally ....................... 196

16. Views on board responsibilities when a company is under financial stress ................199

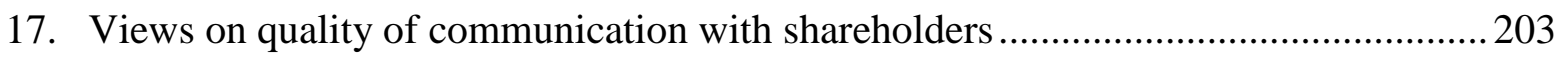

18. Views on the number of independent directors on a board.......................................2204

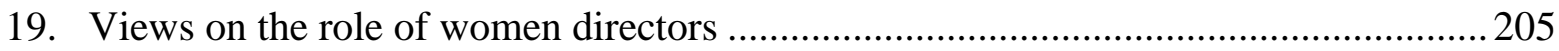

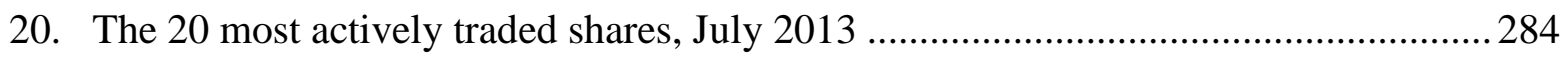


LIST OF ABBREVIATIONS

\begin{tabular}{|c|c|}
\hline Abbreviation & Definition \\
\hline $\mathrm{ACC}$ & Accident Compensation Commission \\
\hline AGM & Annual General Meeting (typically referred to as an ASM) \\
\hline ASM & Annual Shareholders' Meeting \\
\hline ASX & Australian Stock Exchange \\
\hline CalPERS & California Public Employees Retirement System \\
\hline CEO & Chief Executive Officer (not a board member) \\
\hline EVA & Economic Value Add \\
\hline FMA & Financial Markets Authority \\
\hline GAAP & Generally Accepted Accounting Principles \\
\hline GFC & Global Financial Crisis (2007-08) \\
\hline ICGN & International Corporate Governance Network \\
\hline IFRS & International Financial Reporting Standards \\
\hline IPO & Initial Public Offering \\
\hline ISS & International Shareholder Services \\
\hline LSE & London Stock Exchange \\
\hline MD & Managing Director (a CEO who is also a board member) \\
\hline NYX & New York Stock Exchange \\
\hline NZX & New Zealand Stock Exchange \\
\hline NZSX & The main board of the New Zealand Stock Exchange \\
\hline NZAX & The secondary (Alternate) board of the New Zealand Stock Exchange \\
\hline NZIoD & New Zealand Institute of Directors \\
\hline NZSC & New Zealand Securities Commission (replaced by FMA) \\
\hline $\mathrm{OSH}$ & Occupational Safety \& Health \\
\hline ROI & Return On Investment \\
\hline
\end{tabular}




\section{Abbreviation Definition}

ROAE Return On Assets Employed

SOX

Sarbanes-Oxley Act 2002

TIAA-CREF Teachers Insurance and Annuity Association - College Retirement Equities Fund 


\section{INTRODUCTION AND THESIS OVERVIEW}

It is corporate boards that determine one of the most important issues in our society: how the cash that flows from companies is distributed. So the decisions that corporate boards make directly or indirectly influence the wealth of shareholders, employees and company suppliers as well as their families and dependants (Gourevitch \& Shinn, 2009). But what is expected of these boards, to whom are they responsible and what decisions should they make? These are questions that currently do not have clear answers. In this thesis I take a first step towards answering the first of these questions by addressing the question: "What do New Zealand's shareholders and company directors expect from New Zealand's public company boards?" New Zealand is a mature market, and the country has adopted a variant of the classic AngloSaxon corporate governance model so this research also has international relevance.

The international literature on corporate governance leaves open a degree of latitude when addressing some of the fundamental questions of governance, such as, what tasks should a board perform and to whom is it responsible? (Petrovic, 2008). Furthermore, it is generally acknowledged that many of the theories that attempt to either describe or predict board behaviour are incomplete (Dalton, Daily, Certo \& Roengpitya, 2003). An added challenge to gaining an understanding of corporate governance is that research into many of its aspects fails to elicit repeatable results across multiple studies (Brickley \& Zimmerman, 2010). However, researchers generally agree that aspects of governance are jurisdiction specific and that the learning from one country cannot necessarily be applied to another without due consideration being given to the local environment (Davies \& Schlitzer, 2008). When conducting governance research an understanding of the local governance environment and how it differs from that described in international literature is required. Given this local aspect to corporate governance, questions regarding the expectations that New Zealand shareholders and directors have of their boards are best answered with primary research. 
New Zealand research in this area is scant (Ingley \& Van der Walt, 2005). Most of it predates the 2007-8 global financial crisis (GFC) and the subsequent changes to financial market regulations; these are events that in other jurisdictions, it has been argued, have changed board behaviour (Conyon, Judge \& Useem, 2011). Therefore my first research task was to review aspects of the New Zealand commercial environment, including the role of public companies in the national economy, their ownership and demographics (along with those of their shareholders and directors), and the legal and regulatory environment.

Governments and regulators have traditionally had relatively little involvement in defining the role, function and responsibilities of boards. Since its inception, corporate governance legislation in Anglo-Saxon jurisdictions has always treated boards with a light hand (Herrigel, 2006). Beyond mandating that companies form boards and perform a few basic activities, legislators have for the most part left it up to boards themselves to organise their affairs as they see fit. Indeed, at a fundamental level, little has changed since the first UK Companies Act was introduced (Joint Stock Act, 1844). Changes in law and regulation, where they have occurred, have generally happened in response to some real or perceived failure of the market. In the United States, for example, the Securities and Exchange Commission (SEC) was established as a direct result of the 1929 banking failure, which was the event that led to the Great Depression (Securities and Exchange Commission, 2014). More recently the Sarbanes-Oxley Act of 2002 (SOX) resulted from the high-profile failure of companies including Enron and WorldCom (Coates, 2007).

Stock exchanges, through their listing rules, have always mandated certain structural and procedural aspects of board activity for public companies, but they also leave most substantive issues to boards to address as they see fit (NYSE, 2010; NZX, 2013). Since the 1960s, stock exchanges, major institutional investors and others have attempted to exert some 
influence over board activities by promoting initiatives such as best practice codes, board selfevaluation schemes and board charters (Long, 2006; Gregory 2008). All of these initiatives have been designed in part to satiate investors' demands for increased protection from the actions of both boards and management (Davies \& Schlitzer, 2008). Overall the impact of these initiatives has been limited because compliance has generally been voluntary. Even when these initiatives have been made compulsory they have proved difficult to police effectively, leaving it to boards to decide what they will and will not implement. Given that boards are renowned for the secrecy surrounding their activities, (Leblanc \& Schwartz, 2007) they are able to reduce their obligations to simple box-ticking exercises if they so choose. Lord Halifax summed up the situation well when he said that 'the trouble with boards is that they mark their own exam papers' (Garratt, 2004). That this quote from Halifax, who died in 1959, is still relevant today is a small but telling illustration of how slowly change happens in the boardroom. There is evidence suggesting that this change occurs in waves triggered by economic crisis. Most recently, the GFC instigated a series of corporate failures which were in large part attributed to failures of governance. This, in turn, motivated investors worldwide to demand increased protection from the actions of both directors and management (Conyon et al., 2011). In the US, legislators responded by introducing the Dodd-Frank Act (2010), while in New Zealand the Securities Act received a major rewrite and the Financial Markets Authority was established (Securities Act 1978 reprint 1/2014; Financial Markets Authority Act 2011). In addition, clauses of the NZ Companies Act 1993 relating to directors' behaviour were tested in the courts for the first time. The overall effect of these events is that directors are now being held to a higher standard and appear more accountable for their actions than ever before. In exceptional cases a failure to meet standards has resulted in NZ directors being incarcerated (Bond, 2012).

Boards are also coming under pressure from other sources that are not traditionally associated with governance. For example, employees and unions have encouraged legislators to 
make directors accountable for company occupational safety and health issues, an area traditionally delegated to management (Bridges, 2014). And women's groups are demanding greater representation for women on boards (Branson, 2011). As in other aspects of society the internet and digital technologies are having an effect on governance. For example, in many industries digital technologies are changing the fundamental way that companies compete, and the challenge for their directors is to keep abreast of technological changes in order that they might provide useful advice to company managers; advising management is an activity that boards regularly engage in (Ong \& Wan, 2008). Overall these external pressures are likely to be changing the role of the board and the activities they perform and consequently what directors and shareholders expect of boards. This thesis examines how boards are responding to aspects of this new regulatory and commercial environment and the expectations that both directors and shareholders now place on them.

Shareholders feature prominently in theories surrounding governance; for example, the application of agency theory to governance generally casts shareholders as the principal in the principal-agent relationship that is central to this theory (Jensen \& Meckling, 1976). The question that arises, and has yet to be answered in the New Zealand context, is this: "do shareholders see themselves as owners who have contracted with directors to do their bidding and, if so, are boards worth the 'agency' cost?" Another common theory applied to governance is shareholder theory (Friedman, 1962), which is predicated on a set of assumptions about shareholder characteristics that are largely untested in the NZ environment. For example, the theory characterises shareholders as owners, but in practice this may not be the most appropriate definition. Issues such as these were first raised by Berle \& Means in their 1932 classic The Modern Corporation and Private Property, but have not been definitively answered in the context of twenty-first century New Zealand. 
The role of the shareholder in governance is set out in law (Companies Act 1993). When a company is trading normally, the most significant governance tasks that shareholders are called upon to perform are to elect the directors and to quiz them once a year at an annual shareholders' meeting (ASM). From time to time shareholders may also approve or decline certain major transactions (Companies Act 1993). But just as there is very little understanding of how well boards perform their role, there is also very little understanding of how well shareholders perform theirs. Do shareholders take seriously their responsibilities toward the companies in which they hold shares, and do they execute their responsibilities with due care or do they consider these tasks to be simply box-ticking exercises that require no serious consideration? These are important questions - the New York Stock Exchange (NYX), for example, recognises their significance when it reminds shareholders of their duties and responsibilities and encourages them to 'vote their shares in a thoughtful manner' (NYSE, 2010, p. 3). In the New Zealand context there is no comprehensive research into the role of shareholders in corporate governance. This thesis begins the process of addressing this lacuna in the literature by developing an understanding of the expectations of both directors and shareholders.

A brief example involving the UK-based confectionery manufacturer Cadbury provides a practical example of why these questions matter. There was a period when Cadbury was under threat of a hostile takeover by the US conglomerate Kraft. Its shares were trading at $£ 8.00$ and some hedge funds decided that there was $20 \mathrm{p}$ per share to be made if they purchased a strategic stake in the company. Their hunch proved correct: they purchased the shares and just weeks later achieved their objective by tipping the takeover in favour of Kraft (Bennedsen, 2014). In the opinion of Roger Carr, the former chairman of Cadbury, the fate of the 186-yearold, quintessentially British company was decided by a handful of shareholders who had owned their shares for just a few weeks and were interested only in a small, short-term gain. Carr is 
not alone when he states that he doesn't believe that this is how the fate of the company should have been decided (Bennedsen, 2014). The case clearly highlights the importance to boards, regulators and, indeed, investors themselves of understanding more about the nature and demographics of shareholders. If we are to progress our understanding of governance in New Zealand then it is important that we also progress our understanding of New Zealand shareholders.

Shareholders' and directors' expectations of governance may differ in certain circumstances. While little has been published about the nature of these differences, it is relatively easy to foresee situations whereby such differences could arise and cause considerable frictions between the groups. Returning to the Cadbury case, had it occurred in New Zealand, Carr would have been entitled to defend the takeover from Kraft if he believed that doing so was in the company's best interests. Such defensive action would have been against the wishes of the majority of shareholders, who were in favour of the takeover, and would have undoubtedly led to friction between the board and those shareholders.

Understanding the differences between each group's expectations, then, is clearly important not only from a practical perspective but also in order to develop a sound theoretical framework for governance. ${ }^{1}$

There is no question that public companies play a significant role in determining the wealth and quality of life for many in our society (Gourevitch \& Shin, 2009). Directors and shareholders alike are expected to contribute to this situation. Yet in spite of the importance of both the director and shareholder roles, sitting as they do at the heart of corporate governance,

\footnotetext{
${ }^{1} \mathrm{NZ}$ law allows directors to oppose a takeover that they believe to be not in the best interests of the company, whereas under UK law directors must follow the shareholders' directive. This highlights the importance of observing country-specific factors when utilising governance literature.
} 
very little is known of these groups and what they expect from corporate governance. Who are these shareholders and directors, what do they believe is their role in the governance, and what are their motivations? These are important questions that warrant further exploration - not only to place our understanding of corporate governance on a more empirical footing, but also because these groups play such an important role in our capitalist system. This thesis sets out to expose these questions as substantial and complex issues that do not lend themselves to simple 'sound bite' answers. Furthermore, it will be shown they cannot be satisfactorily answered if approached from a single perspective or with the use of a single tool, and that this is an area where opinions and perspectives may prove to be as important as hard facts. Rather, we need to approach the issues from multiple perspectives and conduct multiple pieces of research, and then use the results to triangulate towards a more complete understanding - as is the case with this research.

\subsection{The Significance of the Research}

New Zealand is a small market that has adopted a variant of the classic Anglo-Saxon corporate governance model. The advantage of conducting research in this environment is that good quality data are available and both directors and shareholders are relatively accessible. New Zealand boards have a lot of exposure to directors from other jurisdictions and the legal environment is not dissimilar to other Anglo-Saxon jurisdictions; consequently the research has the potential for international relevance.

The research is intended to contribute to the body of corporate governance literature in the following ways:

1. To provide a better understanding of the expectations that directors and shareholders hold of the purpose, goals and objectives of corporate governance in New Zealand. 
2. To elucidate any differences between shareholder and director expectations of New Zealand public company boards. The research is timely given that the issue is at the heart of a number of recent lawsuits, including the class action by shareholders of the failed carpet firm Feltex against their former directors (Underhill, 2012) and the case of the Crown vs former Justice Minister Douglas Graham (R vs Graham, 2012).

3. To provide some insight into the applicability of popular definitions and theories of corporate governance in the New Zealand context. This will be achieved by exploring how shareholders and directors approach corporate governance and what they expect boards to achieve.

4. To provide an up-to-date picture of the environment in which corporate governance in New Zealand operates. This understanding will provide future researchers with a more robust stepping-off point for their research into many aspects of New Zealand governance by clarifying some of the fundamental assumptions that researchers are currently forced to make due to a lack of evidence. It will also help researchers place learnings from New Zealand research in an international context.

Given that the research investigates an area seldom examined, it can be expected not only to provide a useful contribution to the literature but also to be of assistance to organisations such as the Institute of Directors, the New Zealand Stock Exchange (NZX), the Shareholders' Association and the Financial Markets Authority, all of whom have an active interest in this area.

\subsection{Organisation of this Thesis}

The remainder of the thesis is organised as follows. 
Chapter 2 reviews the relevant definitions and theories of corporate governance. It looks into some of the broader international literature surrounding corporate governance in order to provide a global context for the research. It compares and contrasts the basic definitions and common theories of governance, providing the working definitions that will be used throughout the thesis. It also discusses theories - namely agency, stewardship, stakeholder, and shareholder - that are commonly used to explain aspects of the board-stakeholder relationships. The governance practices of the US, UK and other key jurisdictions are then discussed, compared and contrasted to the NZ governance framework; this enables research drawn from these jurisdictions to be applied to the New Zealand context. Finally the chapter evaluates the literature surrounding a number of board performance and evaluation topics. These topics are reviewed because they touch on potentially contentious issues for both shareholders and directors and are therefore likely to influence the expectations of both parties.

Chapter 3 discusses the goals and objectives of the research and details the specific research questions that are addressed by this thesis. It outlines the overall approach to the research, and discusses the research methodologies that are adopted at each stage. Ethical considerations and data security issues are also addressed.

Chapter 4 examines the governance environment for New Zealand's public companies from the perspectives of shareholders, directors, the companies themselves and the legal environment. These sections examine some historic research that has been extended with 2013 data generated specifically for this research. In addition new research has been conducted drawing on data from secondary sources which investigates aspects and features of New Zealand companies, shareholders and directors that have not previously been researched.

Chapter 5 discusses some initial focus group research that was conducted to assess whether the research was addressing the issues that both shareholders and directors considered 
most influenced their expectations of the role of the board. The findings from this study's two principle pieces of research are then presented in Chapters 6 and 7. Chapter 6 presents the results of an analysis of the minutes from ASMs. These meetings are the only occasion on which most shareholders formally meet with the directors, so the minutes provide a unique record of the direct interaction between these two groups. Chapter 7 evaluates the survey responses that canvass the opinions of directors and shareholders towards boards.

Chapter 8 draws together the results from the individual research initiatives that are discussed in Chapters 4 to 7, and compares and contrasts these findings to identify common themes and highlight any anomalies or contradictions in the research. Chapter 9 presents the conclusions drawn from this research and summarises the contribution of the thesis to the overall body of literature. 


\section{LITERATURE REVIEW}

In this chapter, the literature relevant to the role of shareholders and directors in corporate governance is reviewed. The chapter defines the key terms and some of the popular theories used in the field. It also investigates international practices, and finally examines some of the literature relating to board performance and evaluation.

This review shows that there is no universally agreed definition for the term 'corporate governance', nor is there a consensus on the role of the board, and that this has the potential to create ambiguity and confusion. Because certain terms are central to this research, some of the many definitions in common use are examined and appropriate working definitions established. Four of the most popular theories that are applied to governance are examined, namely the agency, stewardship, stakeholder and shareholder theories. These theories outline different philosophical approaches to governance and they provide insights into shareholder and director behaviour and hence their expectations of boards. Because these theories are central to much of the published corporate governance research, an understanding of their strengths and limitations is required in order to interpret this research.

Corporate governance models vary from country to country (Davies \& Schlitzer, 2008; Agarwal, Erel, Stulz \& Williamson, 2007). The corporate governance models of four countries are examined: the US, UK, Germany and China. The US and the UK were selected because, like New Zealand, they are based on the Anglo-Saxon model of corporate governance and, as will be shown, are the source of much of the literature on which New Zealand research is based. However, as was shown with the Cadbury acquisition case discussed in Chapter 1, relatively subtle variations in these models can have major implications on the way corporate governance is practised, so it is important to understand the nuances of these environments before applying any conclusions to New Zealand. The German corporate governance model is 
discussed because it provides a contrasting model of governance and serves to highlight how even fundamental aspects of corporate governance can be approached in different ways. Finally, the Chinese corporate governance model is comparatively new, being based in part on what Chinese officials consider to be current international best practices, so it provides a useful contrasting reference point (Yang, Chi \& Young, 2011).

Literature examining board performance and evaluation is also reviewed. Because governance practices vary across jurisdictions, not all of this body of literature is necessarily relevant within the New Zealand context, so the research is confined to those topics that are considered likely to influence directors' and shareholders' expectations of boards. The topics discussed are: director independence, CEO remuneration, board size, corporate governance codes, board self-evaluation, and external corporate governance rating systems. Finally, attributes of the key protagonists - the directors themselves - are examined.

\subsection{Definitions of Corporate Governance}

The term 'corporate governance' is used frequently by researchers, commentators and practitioners, but, as the following table shows, it has no universally agreed definition. In practice, because the term is so commonly used it frequently goes undefined and has a takenfor-granted character. Table 1 shows a sample of the definitions used in the literature. 


\section{Table 1.}

Definitions of corporate governance

Definition

Author

If management is about running businesses, governance is (Tricker, 1984, p. 4) about seeing that it is run properly.

The system by which companies are directed and

(Cadbury, 1992, section

controlled.

The mechanisms which ensure that shareholders receive a

(Shleifer \& Vishny, 1996, return on their investment.

p. 737; Macey, 2008, p. 1)

The subset of a firm's contracts that help align the actions (Armstrong, Guay \&

and choices of managers with the interests of shareholders. Weber, 2010, p.181)

All the influences affecting the institutional processes, Turnbull, 1997, p. 183 including those for appointing the controllers and /or regulators, involved in organising the production and sale of goods and services.

The determination of the broad uses to which resources will (Daily, Dalton \& be deployed by the organisation and the resolution of Cannella, 2003, p. 371) conflicts among participants in organisations.

The system of checks and balances, both internal and (Solomon \& Solomon, external to companies, which ensure that companies 2004, p. 14)

discharge their accountability to all their stakeholders and act in a socially responsible way.

Thinking about strategic issues, rather than the operational day-to-day running of the business.

(NZ Institute of Directors, 2012)

This lack of a clear and unambiguous definition can be problematic. Each of the definitions outlined has a set of assumptions about what corporate governance is all about and what problems corporate governance is intended to solve. Therefore, the choice of definition 
influences the direction and interpretation of any subsequent debate and analysis, and it also has the potential to shape the views and opinions of directors and shareholders.

A theme that is central to most of these definitions is the concept that governance involves some degree of monitoring and control of the business operations. This theme is either specifically addressed in the definitions (e.g. Solomon \& Solomon, 2004; Cadbury, 1992; Donaldson, 1990), or is implied (e.g. Tricker, 1984). Beyond this theme differences of opinion emerge. The stakeholder theory versus shareholder theory debate, for instance, which essentially addresses the merits of placing either shareholders or all stakeholders at the locus of the enterprise, features in some of the definitions. For example Shleifer and Vishny (1996) favour shareholders, while Solomon and Solomon (2004) argue that governance should benefit all stakeholders. The scope of the definitions varies from the exceptionally broad to the very specific. Tricker (1984) considers that governance is about ensuring the business is run properly, which is an exceptionally broad definition, so broad as to the point of arguably being unusable. At the other extreme, the Daily et al. (2003) definition focuses on the two specific issues of resource allocation and conflict resolution; yet this is seemingly to the exclusion of all other activities, including those that are mandated by law, such as reporting to shareholders. The overlap between governance and strategy also creates ambiguity. The NZIoD (2012) essentially sees strategy and governance as almost being one and the same; others such as Cadbury (1992), Tricker (1984), and Daily et al. (2003) leave room in their definitions for some overlap between strategy and governance; while Turnbull (1997) and Shleifer and Vishny (1996) appear to see no implicit connection between the two.

Given the diversity that exists within the definitions of governance the opportunity exists for both shareholders and directors to choose a definition of governance that meets their needs and supports either their collective or their personal views and preferences. For example, 
shareholders may gravitate towards the Shleifer and Vishny definition, which focuses specifically on their needs, while directors may favour the NZIoD definition, which defines a far broader role for the board and seems to imply there is less accountability for its actions.

As stated previously the choice of definition influences the scope of any subsequent discussion. In the context of this research, it is necessary to use a broad definition that does not introduce significant biases or restrictions in terms of the scope of the governance activity or the party whom the activity is intended to benefit. Furthermore, the definition should not exclude any particular activity generally undertaken by boards, nor any of the common governance theories. In this context, none of the definitions discussed is entirely satisfactory as they all appear to introduce their own biases and restrictions on governance. In order to meet the requirements of this research a working definition has been developed, which is 'the relationship and interaction of the board with its environment'. This definition does not aim to exclude any of the themes identified in Table 1; furthermore, it delineates governance from operational management, thereby specifying a boundary on the role of governance. Lastly, this definition is not intended as an alternative to those outlined in Table 1; its purpose is simply to define the term and some boundaries for this research.

\subsection{The Role of the Board}

The role of the board is absolutely central to corporate governance. Although there is general agreement that the board's role must be defined, there appears again to be little consensus on the form this definition should take (Petrovic, 2008; Lipton \& Lorsch, 1992). Table 2 summarises the significant activities that underpin some of the more common definitions of the board's role. 


\section{Table 2}

Primary board responsibilities

Primary board responsibilities

Strategy, leadership, controlling management and reporting.

Shareholder advocate.

Directing, controlling and reporting.

Contingency approach; directors effectively define their own roles.

Monitoring, serving management, strategy and resource provision.

\section{Advocates}

Moltz, 1985, p. 87;

Cadbury, 1992, section 2.5;

OECD, 2004, p. 24.

Shleifer \& Vishny, 1996, p. 737;

Monks, 2001, p. 146;

OECD, 2004, p. 18;

Macey, 2008, p. 1.

Forbes \& Milliken, 1999, p. 492;

Aguilera, 2005, p. 42;

Nicholson \& Kiel, 2007, p. 10.

Blake, 1999, as cited in Long

2006, p. 548;

Huse, 2005, p. 68.

Ong \& Wan, 2008, p. 318.

Table 2 is not intended to be comprehensive, but to highlight themes common to many of the definitions of the role and activities of the board. It does, however, support the assertion that there is only limited consensus on the role of the board (Donaldson, 1990; Monks \& Minow, 1995). This lack of consensus has potential to influence stakeholder expectations. Shareholders, for example, may be attracted to Macey's (2008) definition, which makes their interests paramount, while directors may favour Cadbury's (1992) definition, which gives the board a more active role in defining the direction of the company.

One reason for this lack of consensus may be that the role of the board varies from enterprise to enterprise (Adams, Hermalin \& Weisbach, 2010). Another contributor to this ambiguity is created by different conceptualisations of the mix of the 'what' of the board role 
with the 'how' of the role (Nicholson \& Newton, 2010). The 'why' of the role may also contribute to this ambiguity. For example, Macey, a well-known shareholder advocate, sees the role of the board as simply ensuring that management serve shareholders (Macey, 2011, p. 1). Conversely Cadbury makes no reference to shareholders or returns to shareholders in his definition; instead, he sees the board as being responsible for setting the strategic direction of the company and providing leadership (Cadbury, 2010).

Cadbury's view - that boards take a leadership role and set strategy - is in practice more radical than it first appears because, as will be shown, NZ boards are dominated by independent directors. Independent directors, by definition, have little or no direct management experience of the company they govern. Because of this lack of hands-on experience it can be argued that they are not best equipped to develop strategy, and that a more appropriate role for the board may be to evaluate and monitor the strategy developed by management. Previous NZ research has provided some evidence that suggests that some directors support the Cadbury (2010) view, e.g. Northcott \& Smith, 2011 and Ingley \& Van der Walt, 2005. There is however, no research that I am aware of which examines the issue from a shareholder perspective which is a significant omission given the role of shareholders in governance.

Another stream of the literature considers that the role of the board is set by individual directors according to the circumstances (Blake, 1999; Huse, 2005), which include factors such as geography, industry type, ownership dispersion, firm size, business life cycle, and the tenure of the CEO. This contingent approach may appeal to some directors. New Zealand boards do, however, have obligations imposed on them from a variety of sources, including legislation and stock exchange regulations. These obligations play a largely non-negotiable part in defining the role of the board and therefore place some limitations on the contingent aspects of corporate 
governance. So in practice there are aspects of corporate governance which are not represented in this definition.

These examples show that there is a range of definitions for the role of the board that on face value appear to be more aligned with the interests of one stakeholder group than with another and therefore have the potential to bias the research. Eliminating any such bias from this research calls for a working definition for the role of the board that is sufficiently broad as to capture all of the tasks performed by boards and does not favour any particular stakeholder group. Based on these criteria the role of the board has been defined as 'to perform those activities necessary to meet the expectations of the key stakeholders and to meet its legal obligations'. This definition is not intended to be a general alternative to the definitions outlined in Table 2; rather it is simply a working definition that defines a boundary for this research.

\subsection{Theories Addressing Governance}

In this section, four of the theories that are most commonly used in a governance context are examined. Each is examined from the perspective of understanding shareholder and director attitudes and views of governance. Agency theory and stewardship theory are both descriptive/empirical and instrumental theories which are used to describe and explain how certain aspects of governance operate and to predict certain behaviours and outcomes. Shareholder theory and stakeholder theory, on the other hand, are predominantly normative theories that describe a philosophical approach to operating businesses. However, they are also on occasion used as descriptive/empirical theory to describe what is happening within an organisation (Donaldson \& Preston, 1995). While none of these theories attempts to explain governance as a whole, they all provide pointers towards the expectations that shareholders and directors have of boards. 


\subsubsection{Agency theory}

Agency theory was developed to help understand the problems that arise when one party (a principal) gets another party (an agent) to perform certain tasks. Agency theory makes some assumptions about the parties (self-interest, bounded rationality and risk aversion), and, based on these assumptions, it is used to examine the contract between two parties. From an agency theory perspective two problems can occur with this contractual arrangement: firstly the parties can have different, possibly conflicting objectives; and secondly, the parties can have a different appetite for risk (Jensen \& Meckling, 1976).

Agency theory is the most common theory that is used to explain corporate governance behaviours (Dalton et al., 2003). Indeed, a recent review of research into governance in leading US and international academic journals found that in 54\% of articles agency theory was employed as the main theoretical perspective (Gabrielsson \& Huse, 2004). The theory is used in a wide range of areas such as the role of independent directors (Aguilera, 2005), CEO remuneration (Gregory-Smith, 2011), board structure (Fauzi \& Locke, 2012), board size (Conyon \& Peck, 1998) and CEO duality (Boyd, 1995). However, meta-analysis of many of these types of studies has found little statistical evidence to support the veracity of the theory when applied to many of these issues (Dalton et al., 2003). While agency theory is criticised from a number of perspectives (Daily et al., 2003; Huse, Hoskisson, Zattoni \& Viganò, 2009), an underlying reason why the theory is not as insightful as would be expected, particularly given its popularity, is that the assumptions made about the principal and agent may not always be correct. Nonetheless, possibly because of the simplicity of the theory reducing, as it does, complex problems to just two parties and one contract, it continues to be used extensively in extant research (Daily et al., 2003). 


\subsubsection{Stewardship theory}

Stewardship theory can be considered as either a complement or an alternative to agency theory. Stewardship theory defines situations in which managers are not motivated by personal goals, but rather are stewards whose objectives and motives are aligned with those of their principals (Davis, Schoorman \& Donaldson, 1997; Sundaramurthy \& Lewis, 2003). The key difference between agency and stewardship theories is an assumption about human nature. Agency theory assumes that people are individualistic utility maximisers, while stewardship theory advocates that people self-actualise and achieve utility through organisational achievement (Davis Schoorman \& Donaldson, 1997). Stewardship theory proponents argue that if the CEO's objectives are aligned with the shareholders', then the fewer constraints imposed on the CEO the better.

Stewardship theory is subject to some of the same criticisms as agency theory, in that the assumptions regarding human nature underpinning the theory cannot be applied in all governance situations or across all jurisdictions. So with agency theory, we have a situation in which directors and shareholders can draw on a theory to justify contradictory positions on a wide range of corporate governance issues.

\subsubsection{Stakeholder theory}

The underlying principle of stakeholder theory is that companies exist not only for the benefit of shareholders, but for the benefit of all parties that have a stake in the organisation, and therefore no specific group of stakeholders or any individual party's interests should be placed above any of the others (Jensen, 2001). Stakeholder theory justifies this assertion by arguing that a firm cannot maximise value if it ignores the interests of its stakeholders (Jensen, 2001; Smith, 2003; Freeman \& Reed, 1983). A challenge with stakeholder theory is identifying and 
evaluating the needs of the large number of stakeholders that are involved with a modern corporation. This leads to the claim that, because stakeholder theory is encouraging boards to be accountable to all stakeholders, it is in effect making a board accountable to everyone, which is akin to being accountable to no one (Sternberg, 1997).

\subsubsection{Shareholder theory}

Shareholder theory asserts that the primary responsibility of a firm is to maximise the wealth of its shareholders (Friedman, 1962, p. 112). Advocates of the theory argue that because shareholders are the residual claimants on a firm's profits (profits being what's left after all other stakeholders have been satisfied), by default it takes into consideration the other stakeholders' needs. A criticism of shareholder theory is that it places too much emphasis on shareholder objectives and that these objectives may not always be in the best long-term interests of the company. For example, pressure from shareholders has led boards in the US to adopt shareholder wealth maximisation strategies, which in turn have led to a very short-term focus for companies and arguably created a culture of excessive risk taking (Lazonick \& O’Sullivan, 2000; Gamble \& Kelly, 2001).

\subsubsection{Summary of theories addressing governance}

The problem with the theories discussed in this section from a perspective of shareholder and director expectations is the lack of consistency between them. Applying the two normative theories, stakeholder and shareholder, to common governance issues can result in different outcomes. Similarly, using agency theory and stewardship theory to interpret corporate governance activity is likely to result in different and possibly contradictory interpretations of the activity. The impact can potentially be significant and, as will be shown in subsequent sections, these differences between theories can influence the interpretation of some 
fundamental aspects of governance including board accountability, board control, and CEO power. This apparent lack of consistency between theories also highlights the possibility that both shareholders and directors can disagree on various aspects of corporate governance and yet support their position by citing one of these established governance theories.

The differences in outcome that can occur when applying different theories to the same situation suggests that selecting the appropriate theory to apply is arguably as important as the application of the theory itself. One factor that may influence the appropriate selection of theory is the status of the external environment. The link between corporate governance practices and the broader organisational environment is not generally discussed in the classic treatise on these theories (e.g. Jensen, 2001; Eisenhardt, 1989). However, it has been postulated that the lack of consideration for this link is a limitation in these theories (Aguilera, Filatochev \& Jackson, 2008).

The mutually contradictory aspects of these theories highlight the importance of research such as this, which can assist in calibrating the theories against actual board experience and practice and can also explore the link between governance practices and the broader commercial environment.

\subsection{International Corporate Governance}

The practice of governance differs substantially from country to country. The legal framework, the extent to which governance is aligned with either stakeholders or shareholders, financial systems (e.g. bank versus market driven) and the political governance of the economy (e.g. state directed, associational, or market driven) along with societal and cultural values all influence the fundamental features of a country's governance system (Davies \& Schlitzer, 2008; Agarwal, et al., 2007). Therefore, in order to determine the applicability of international 
research to the New Zealand environment (and vice versa) it is important to understand the salient features of both the New Zealand environment and the relevant offshore counterparts. Because much of the governance research on which New Zealand research is based emanates from the US or the UK, the governance practices and environments of these countries are examined in some detail. In addition, a brief overview of the key features of Germany and China, whose governance practices differ significantly and therefore act as a useful contrast, are also included.

\subsubsection{United Kingdom}

The first example of a company that resembled the modern corporation with distinct shareholders and a board was the Russia Company, formed in 1553 in the UK (Todd, 1932). By the 19th century the advantages of this type of corporate structure had become widely apparent. Specifically, the unlimited life of the corporation, the transferability of ownership and the limited liability of the shareholders were well understood and this, combined with a need to raise large amounts of capital to execute many of the business opportunities that were then available, resulted in corporate structures becoming the preferred structure (Grant, 2003). In the 19th century the directors of a company were all shareholders in their own right and they generally worked full time in the company in senior executive positions (Todd, 1932). In addition to their executive duties, they also had some relatively minor responsibilities for monitoring their company performance and reporting on progress to the body of shareholders. These duties were specified in the UK Joint Stock Companies Acts of 1844 and 1854.

The 1844 Joint Stock Companies Act defined the substantial powers and responsibilities of both the directors and the shareholders. It states that the directors are responsible for actively managing the company and reporting to shareholders. Specifically the Act states that directors must: 
- conduct and manage the affairs of the company, and for that purpose enter into such contracts and to execute all such acts and deeds as the circumstances require;

- appoint and remove the secretary, clerks and servants, and appoint and remove other persons for special services as required;

- hold meetings periodically and from time to time as the concerns of the company shall require;

- appoint a chairman to preside over such meetings (Joint Stock Act 1844, p. 433).

During the course of the 19th century, board members progressively withdrew from the day-to-day management of the company, and consequentially the requirement to monitor management and report to shareholders increased (Todd, 1932). However, the UK government continued with a largely hands-off approach to governance, leaving shareholders to determine the rules, roles and responsibilities of the board through the company's articles of association. The current (1985) version of the UK Companies Act states, quite simply, that public companies require only two directors and that the board must perform certain administrative and reporting tasks. Those tasks appear, by the author's assessment, to be similar to those outlined in the 1844 Act. $^{2}$ In this environment a model of corporate governance has developed that is known as the Anglo-Saxon model. The underlying assumption of this model is the concept of market capitalism and that the idea that the purpose of a company is to serve its shareholders (Cernat, 2014). The model assumes that shareholder interests are best served by decentralization and self-regulation. This has led to an environment where ownership of public companies is widely dispersed and the stock exchange takes a prominent role in facilitating raising the capital (Cernat, 2014). Companies are structured with a single board, usually with

\footnotetext{
${ }^{2}$ Each UK and NZ Companies Act from 1844 has been compared to its predecessor and the significant inclusions and omissions from a corporate governance perspective have been noted. The details of this analysis are beyond the scope of this research and therefore have not been included.
} 
the roles of chairman and CEO separated, and employees play no role in the governance of the company (Cernat, 2014).

Even though the UK government has left corporate governance largely unregulated, it has arguably led the world down a path of governance reform by promoting best practices through a series of recommendations based on the findings of expert committees (Larcker \& Tayan, 2013). The findings of these committees have influenced not only UK corporate governance practices but also New Zealand governance practices, as will be shown. This approach of voluntary codes of practice that focus on the concepts and broad principles contrasts with the US practice, which relies heavily on detailed and specific regulations (Kane, 2012; Romano, 2004).

The Cadbury Report (1992) laid the fundamentals for empowering boards and limiting CEOs' influence over the board and decision making (Zalewska, 2013). Among the recommendations made were the separation of the chairman and the CEO, the appointment of a significant number of independent directors, an independent audit committee, reducing conflicts of interest between directors and the company, and improved financial reporting. To encourage compliance, the London Stock Exchange has incorporated many of the recommendations into its listing rules, but, rather than make compliance mandatory, it has adopted the 'comply or explain' approach, whereby issuers are required to either comply with the rules or explain the reasons for not doing so (London Stock Exchange, 2014). The report also led to the UK's first combined UK Corporate Governance Code (Financial Reporting Council, 2010). Despite the widespread adoption of the Cadbury Report there is scant evidence to suggest that these reforms have had any positive impact on company performance (Weir \& Laing, 2000). 
The Cadbury Report was followed by the Greenbury Report (Greenbury, 1995), which recommended independent remuneration subcommittees, and the Turnbull Report (Turnbull, 1999), which looked at risk management, and finally the Higgs Report (Higgs, 2003). The Higgs Report placed more emphasis and responsibility on independent directors and recommended board self-evaluation. Most of the recommendations of these reports have subsequently been incorporated into the Combined Code of Corporate Governance (Financial Reporting Council, 2010). Many of the issues raised, such as the role of independent directors, age limits on directors, and CEO remuneration, have been the subject of public and shareholder scrutiny (Brickley \& Zimmerman 2010; Sonnenfeld, 2004). The lack of evidence-based research to support many of the recommendations made in these reports appears not to have been an impediment to their incorporation into the combined code.

\subsubsection{United States}

The foundations of corporate governance in both the US and the UK are similar to those of New Zealand. Indeed, even today the laws of the three countries have much in common. However, a number of factors, including the size of companies, the spread of shareholders, the way the law has been interpreted, and the emphasis on regulation, have created a governance environment that is quite different to the New Zealand environment.

One of the early defining pieces of US case law was set by a case between a shareholder, Mr Dodge, and the Ford Motor Company. In this case the courts decided that: 'The directors of a corporation, and they alone, have the power to declare a dividend of the earnings of the corporation,' and that 'a business corporation is organised and carried on primarily for the profit of the stockholders. The powers of the directors are to be employed for that end.' (Dodge vs Ford Motor Co, 1919, p. 2). With this ruling the courts essentially defined 
where shareholders' powers ended and directors' powers began. It also placed shareholders in a privileged position above that of other stakeholders, a status that is not afforded to New Zealand shareholders (New Zealand Companies Act 1993). On the basis of the Dodge vs Ford ruling, directors secured almost unlimited power over their corporations. It was not until 1942 that shareholders could even put resolutions to a vote at a shareholder meeting; that right was enshrined in UK and NZ law nearly 100 years previously (Joint Stock Act 1844). Even today the process for getting a shareholder resolution tabled in the US is not straightforward because the rules of the Securities and Exchange Commission (SEC) allow directors to reject shareholder proposals for a wide variety of reasons (Grant, 2003). However, given the large number of shareholders that most US public companies have and the potential for proposals with narrow interests to be advanced, it is perhaps understandable that such constraints are in place. Proponents of the US governance model argue that a company is not a democracy and therefore democratic principles should not be applied. If investors object to the decisions that the directors are making then they can sell their shares (Thompson \& Edelman, 2009).

The stock market crash of 1929, in which the Dow Jones index fell from a high of 391 in September 1929 to a low of 41 in July 1932, led directly to the US establishing the SEC in 1934. The role of the SEC is to protect shareholders and it undertakes this by endeavouring to ensure that shareholders are kept fully informed, so that they may make rational decisions on the sale or purchase of their securities, and by ensuring that manipulative practices and false and misleading statements are prohibited. It achieves this largely by administering the 1933 and 1934 Securities Acts (one of which deals with new listings and the other secondary trading of shares (Grant, 2003). The SEC is also responsible for accounting standards, although it delegates the process of drafting standards to the Financial Accounting Standards Board (FASB), a not-for-profit organisation comprising experts from industry, accounting firms and academia. 
A curious feature of the US governance environment is the role that the State of Delaware plays in the registration and administration of public companies and the role its judiciary plays in settling commercial disputes. Over $63 \%$ of US companies are registered in Delaware (Larcker \& Tayan, 2013, p. 38). This situation had its origins in the early 1900s when New Jersey began imposing high taxes on corporations. Companies migrated to Delaware largely because its constitution requires a bipartisan judiciary, a structure unique to this state. Over time the Delaware courts have developed a reputation for fairness and speedy resolution in civil litigation. The state's company law has also influenced that of other US states; for example, in recent years Delaware has set standards of conduct for company directors in law, ensuring that the board's focus on processes is more than simply box-ticking exercises. The Delaware courts have a reputation for not second-guessing business decisions, which gives boards some confidence that their decisions will not be judged with the benefit of hindsight (Veasey \& Di Guglielmo, 2005).

Two key pieces of recent legislation have had a significant effect on the US corporate governance landscape. These are the Sarbanes-Oxley Act of 2002 (SOX) and the Dodd-Frank Financial Reform Act of 2010. SOX was introduced in the wake of accounting scandals and corporate failures that had brought down one of the US's largest companies (Enron) and the world's largest accounting firm (Arthur Andersen). The purpose of SOX was to restore investor confidence by improving the accuracy and reliability of corporate disclosures. From a governance perspective, some of the key provisions of the Act are making the CEO and CFO criminally liable for any misrepresentations in the company accounts, ensuring that the majority of audit committee members are independent directors and banning most personal loans to executives and directors. Opinion is divided over the effectiveness of the Act (Petra \& Loukatos, 2009; Linsley \& Linsley, 2008). 
From a governance perspective, the Dodd-Frank Act introduced three key reforms: say on pay, proxy access and increased disclosure. The say on pay amendment led to the SEC mandating that at least once every three years shareholders shall be entitled to vote in a nonbinding referendum to approve or reject the compensation of the company's executives. The increased proxy access enabled under Dodd-Frank makes a limited allowance for substantial, long-term shareholders to nominate directors (SEC, 2010, Rule 14a-11). Previously, nominating directors was virtually the sole domain of the board. By US standards, this is a radical change, one that had been under consideration by the SEC for some 30 years (Schapiro, 2010). Companies must also disclose more information in areas such as executive compensation, the independence of remuneration committee members, and the surrounding decision of whether or not to have an independent chairman. In spite of these increased powers shareholders in the US do not appear to be in a hurry to exercise them, given that the number of shareholder proposals submitted to Fortune 1500 companies has been declining year on year over the last five years. In 2007, 665 shareholder proposals were submitted, dropping to just 417 proposals in 2011 (Georgeson, 2011). Another key element of the US environment is that it has a very active market for corporate control. Quite simply, underperforming companies or companies with weak governance are likely to be acquired or merged with other businesses. This is considered a significant incentive for directors to maximise the short-term performance of their companies (Jensen, 1983; Jarrell, Brickley \& Netter, 1988).

From the perspective of director and shareholder expectations, key differences between the US corporate governance model and its New Zealand counterpart include: the size of US companies relative to New Zealand companies; the expectation that US firms place shareholder requirements ahead of those of other stakeholders; the greater power that is invested in US boards; and the active market for corporate control. 


\subsubsection{Germany}

The German corporate governance system provides an interesting alternative to the AngloSaxon type adopted by, among others, the US and UK. An examination of the German model is useful also in that it highlights and brings into sharp contrast some aspects of the NZ corporate governance model that might otherwise go unnoticed. It is also worth considering for no other reason than that some of the world's most successful and respected companies are listed on the German DAX stock market and are therefore required to comply with its rules (von Rosen, 2007).

Under German law companies are given less latitude than their Anglo-Saxon counterparts to define their own structure and rules. For example, German companies are required to have two boards. One is a supervisory board (Aufsichtsrat), which consists of nonexecutives who are elected annually by the shareholders, and is responsible for compliance issues, major financial decisions and approving the payment of dividends. This board is required by law to have a minimum of $33 \%$ employee representation when the company has more than 500 employees and 50\% employee representation when its employee numbers reach 2000. It is also common for supervisory boards to have representatives from German national banks and members of the company's founding family. The second board is the management board (Vorstand). This board is responsible for strategy, product development, and the operational aspects of the business (Larcker \& Tayan, 2011, p. 45). Notwithstanding that ownership of German companies is less fragmented than in the UK or US, given the influence of banks and employees, German shareholders have far less influence than their Anglo-Saxon counterparts (ibid.). 
In 2002 Germany introduced its first corporate governance code (Regierungskommission, 2015). The code, which draws on the OECD (Organisation for Economic Cooperation and Development) corporate governance code, appears to be a step towards aligning German corporate governance practices with OECD and European best practices. The code makes suggestions that the supervisory board create audit and risk management and remuneration committees. Questions are starting to arise around the composition of supervisory boards and this suggests a possible trend towards a more AngloSaxon-centric governance model over time (von Rosen, 2007).

So overall the German corporate governance model provides a sharp contrast to the Anglo-Saxon model. Given that many successful German companies operate under this regime it demonstrates that there is not necessarily a single best approach to corporate governance.

\subsubsection{China}

China is one of New Zealand's largest trading partners (Statistics NZ, 2013), and while its influence on NZ public companies is relatively small at this stage - there are only three directors of NZSX-listed companies who are domiciled in China, for example, (4.4.5) - it seems likely that trade links will continue to grow, so its influence will increase over time. The Chinese governance model is relatively new and reflects the country's partial transition to a capitalist economic system. Like the German model it also provides a useful contrast to the NZ model.

In 2001 it was estimated that the state controlled some $81 \%$ of shares in publicly listed companies in China. This control is achieved by holding some $9 \%$ of the shares directly and some $72 \%$ indirectly through pyramid share holdings (Yang et al., 2011). Different classes of shares are issued which can be traded on different exchanges in different currencies and by different people (e.g. Chinese nationals and others). Like Germany, China has adopted a two- 
tier board structure, with a supervisory board that reports to shareholders and a management board. Management are not represented on the supervisory board. One-third of the supervisory board must comprise independent directors. However, there is evidence to suggest that the market does not always consider these directors to be independent (Qui \& Yao, 2009). The precise role that banks play in the governance of Chinese companies is not well researched. In many cases the government is majority owner of both the corporations and the banks.

Furthermore, it has been argued that the government frequently places social and political objectives above financial objectives and this has led some commentators to assert that banks, because of their control, are not an effective monitor of company performance (Yang et al., 2011).

In 2002 China also established a corporate governance code that recommends audit nomination and remuneration committees aligned with international best practices. The code is based on the 'comply or explain' principle first introduced in the UK in the Cadbury Report (Cadbury, 1992). However, many companies appear to consider 'comply or explain' to be a loophole allowing them to legally opt out of the more arduous aspects of governance; very few Chinese companies have set up audit committees, for example (Yang et al, 2011). That said, the Chinese approach to corporate governance is changing, and some companies are incorporating features of the Anglo-Saxon governance model, such as independent audit and remuneration committees, into their practices. Change is largely being driven by the expectations of international investors, particularly when these companies list on European or US stock exchanges (Larcker \& Tayan, 2013, p. 52).

From a New Zealand perspective the Chinese model, like the German model, shows that approaches other than the Anglo-Saxon model can provide corporate governance that meets the requirements of key stakeholders. Evidence that some Chinese companies, like their 
German counterparts, are increasingly adopting aspects of the Anglo-Saxon governance model may also be significant as it may suggest a global trend towards a more common set of governance arrangements that are more closely aligned with the New Zealand approach to corporate governance.

\subsubsection{Summary of international corporate governance models}

Table 3 is the authors assessment of some of the key differences in international corporate governance models that have been discussed in the literature reviewed in this chapter, and for comparison purposes it introduces the New Zealand corporate governance model (which will be discussed in detail in Chapter 4).

\section{Table 3}

International corporate governance models

$\begin{array}{llllll} & \text { UK } & \text { US } & \text { Germany } & \text { China } & \text { NZ } \\ \begin{array}{l}\text { Ownership } \\ \text { fragmentation }\end{array} & \text { High } & \text { High } & \text { Low } & \text { Low } & \text { Moderate } \\ \text { Shareholder centric } & \text { Yes } & \text { Yes } & \text { No } & \text { No } & \text { Moderate } \\ \text { Board } & 1 \text { tier } & 1 \text { tier } & 2 \text { tier } & 2 \text { tier } & 1 \text { tier } \\ \text { Employee participation } & \text { No } & \text { No } & \text { Yes } & \text { No } & \text { No } \\ \text { Legal environment } & \text { Strong } & \text { Strong } & \text { Strong } & \text { Weak } & \text { Strong } \\ \text { Bank involvement } & \text { Low } & \text { Low } & \text { High } & \text { Unknown } & \text { Low } \\ \text { Takeover market } & \text { Moderate } & \text { High } & \text { Low } & \text { Low } & \text { Low } \\ \text { CEO duality } & \text { Low } & \text { Moderate } & \text { Nil } & \text { Low } & \text { Nil } \\ \text { Role of stock exchange } & \text { High } & \text { High } & \text { Low } & \text { Low } & \text { Moderate } \\ \text { Size of market } & \text { Large } & \text { Very large } & \text { Large } & \text { Very large } & \text { Tiny }\end{array}$

Table 3 highlights that, even at this very general level, material differences can be seen between the New Zealand governance model and those of other countries. This suggests that 
New Zealand shareholders and directors may behave differently and have different expectations of boards than their overseas counterparts. It also confirms findings (e.g. Davies \& Schlitzer, 2008; Agarwal et al., 2007) that it is important to understand the country-specific aspects of governance practices before applying learnings from other jurisdictions. Because most of the literature on corporate governance referred to in this and other New Zealand based research is sourced from either the US or the UK, differences between these three countries are particularly relevant to this research.

\subsection{Empirical Measures of Boards and the Implications for Stakeholder Expectations}

How boards organise themselves and what they choose to do is likely to influence both directors' and shareholders' expectations of boards. Stakeholders can influence board activity by controlling the size of the board (Boone, Casares Field, Karpoff, \& Raheja 2007) and by influencing board behaviour through corporate governance codes (Davies \& Schlitzer, 2008). Boards have been encouraged to evaluate their performance through self-evaluation processes (Long, 2006) and independent companies have been established in the US and elsewhere to evaluate board performance (Brown \& Caylor, 2004). However, before examining this literature it is first necessary to gain an appreciation of the strengths and weaknesses of the research methodologies that are frequently adopted for such research. This section first discusses the research methods commonly used for empirical research into board performance, then reviews some of the literature on each of these aspects of corporate governance in order to identify elements that are likely to influence shareholder and director expectations. The elements reviewed are: board size, corporate governance codes, board self-evaluation, and external corporate governance evaluation methodologies. 


\subsubsection{Research methodology}

A large body of literature has developed around the idea that company performance is linked to some easily measurable attribute either of the board or of directors themselves. The attributes frequently researched include: board size, CEO remuneration, director independence, and many of the other attributes that potentially influence shareholder and director expectations of boards. Studies tend to rely on easily accessible data and use a relatively standard 'black box' methodology (Gabrielsson \& Huse, 2004). A review of corporate governance research published in leading US and European journals found that $78 \%$ of the research published in the journals was based on this approach (ibid.). Because much of the research referred to in this and the following section is based on these methodologies it is important to understand how the research is conducted and its limitations.

These studies frequently consider the board to be a 'black box' (Gabrielsson \& Huse, 2004), and they look for a relationship between an input to this black box - which is typically some aspect of corporate governance that can be observed without interacting with the directors - and the output, which is some measure of overall company performance. This approach to governance research has the advantage of avoiding interaction with directors, an important consideration given that directors have a reputation for not only jealously guarding their privacy but also operating in near-complete secrecy, making it difficult to engage with them directly (Leblanc \& Schwartz, 2007). Inputs in these types of studies are generally any aspect of corporate governance in which data are freely available, with the size of boards, number of independent directors, and the gender of directors all being typical candidates. The output is typically a proxy for company performance and is generally a group of financial metrics such as ROI, ROAE, Tobin's Q and EVA (Petrovic, 2008). To test for a relationship between the input and output, regression analysis is performed and the results are generally explained in the context of one or more of the popular governance theories. The challenge with these research 
initiatives is that they fail to yield consistently repeatable results (Brickley \& Zimmerman, 2010; Johnson, Daily \& Ellstrand, 1996). Possible reasons for this include:

- Accounting measures. The validity of using basic accounting measures such as ROI and ROAE as a proxy for company performance has long been questioned from an economic standpoint (Chen \& Lee, 1995). Arguably a more fundamental weakness is that these accounting measures seldom reflect company performance as assessed by either shareholders or directors because they do not necessarily reflect the strategic objectives that the company has set. For example, technology companies in their start-up phase frequently drive towards market share even if it results in years of poor financial results.

- Closed system approach. These research initiatives treat the board as a closed system and fail to take into account the impact of external factors, such as economic influences, and shareholder influences on the actions of the board (Finkelstein \& Mooney, 2003). Much of this research still relies on Jensen and Meckling's (1976) application of agency theory (Gabrielsson \& Huse, 2004), which lends itself to considering corporate governance as a two-party closed system.

- Time frames. The research initiatives tend to measure the element of the board under investigation at the beginning of a year and the output (company financial performance) at the end of the year. Given the strategic and long-term nature of much board activity this might not always be the most appropriate time frame on which to measure performance. 
These 'black box' studies are also frequently criticised for failing to take into account the contingent nature of corporate governance (Aguilera \& Jackson, 2003). Indeed, Finkelston and Mooney (2003) and Gabrielsson \& Huse (2004) argue that this type of research does not yield strong research results or lead to robust governance practices. Therefore given these limitations some caution is required when extrapolating the results of such research to more general situations.

\subsubsection{Board size}

The size of the board is a metric that is likely to influence directors' views and expectations of boards more strongly than those of shareholders. From the directors' perspective, a board's size will affect the degree of influence they can exert over it and their ability to 'get things done' (Forbes \& Milliken, 1999). So the size of the board is likely to play a key part in influencing directors' expectations. Shareholders may also have an interest in board size because it is a criterion used by rating agencies who evaluate governance quality on behalf of shareholders (Donker \& Zahir, 2008).

Board size is frequently viewed as a trade-off between firm-specific benefits from the expertise that directors contribute and the cost of monitoring (Boone et al., 2007). However this trade-off may be specious, as the relationship between board size and company performance is one of the few areas where research has reasonably consistently shown a negative correlation across research studies: the larger the board, the weaker the company's performance (De Andres, Azofra \& Lopez, 2005; Eisenberg, Sundgren \& Wells, 1998, Guest 2009). However, there are exceptions and not all research has found this correlation (Conyon \& Peck, 1998; Chin, Vos \& Quin, 2004). 
Boone et al. (2007), in a comprehensive study into the board size of firms from their Initial Public Offering (IPO) through their first 10 years as listed companies, found that, while average board sizes slowly increased over time, this was influenced by economic considerations and by firm-specific issues, such as the power of the CEO and the strength of the management team. They therefore concluded that boards are tailored to meet their own unique environment.

\subsubsection{CEO Remuneration}

CEO remuneration has long been a contentious topic, with debates occurring in the popular press, at ASMs, and presumably within remuneration committees of boards themselves (Tosi, Werner, Katz \& Gomez-Mejia, 2000). Over the last two decades or so CEO salaries in many countries have risen substantially faster than median salaries and arguably faster than company returns (Thomas \& Watson, 2013). This has led to public and shareholder outcry, with much of the criticism being pointed at directors for approving such increases.

Shareholders argue that CEO remuneration is a proxy for management power and influence, and that directors who allow such salaries are captured by management and simply aren't doing their job (Boyer, 2005). While this may not necessarily be the case (Boyd, 1994), the outcry has been sufficient to motivate regulators in many countries including the UK, Australia and the US to introduce so-called 'say on pay' regulations, which give shareholders the right to vote on CEO remuneration (Thomas \& Watson, 2013). While these regulations seem to have been well received by shareholders, directors continue to argue that say on pay is an unnecessary intrusion into their area of responsibility (Bainbridge, 2008).

At the heart of the arguments regarding CEO remunerations is the relationship between the level of remuneration and company performance. International research has shown that in practice, on average, there is relatively little relationship between executive compensation and performance (Tosi et al., 2000). The limited amount of recent research conducted in New 
Zealand has reached a similar conclusion (Elayan, Lau \& Meyer, 2003). However it cannot be assumed from this research that financial incentives given to CEOs are not improving company performance. One possible explanation for the research not identifying the linkage is that the research may not consider the lag between when an incentive payment is made to a CEO and when the performance improvement is apparent. For example, if CEOs are rewarded for initiatives such as making acquisitions, opening new markets or launching new products, then the period in which the compensation is paid may not match the period in which the performance upswing occurs.

\subsubsection{Corporate governance codes}

Corporate governance codes are voluntary sets of principles, standards or best practices that are related to the internal governance of businesses. The codes themselves grew out of a desire to reduce the number of corporate scandals and failures (Davies \& Schlitzer, 2008). Today, guidelines are published by a variety of sources. In New Zealand probably the most wellknown example is the former Security Commission's Corporate Governance in New Zealand: Principles and Guidelines (2011), although the IoD (2012) and the NZX (2012) also publish codes. Many stock exchanges make adherence to a specific guideline a mandatory condition of listing (Gregory, 2008; ASX, 2007; NZX, 2012). Comparing codes highlights issues where shareholders and directors may disagree, as well as topics that they consider important.

Table 4 summarises the key issues addressed in codes developed by the following eight organisations: The New Zealand Securities Commission (NZSC), the New York Stock Exchange (NYX), the Australian Stock Exchange (ASX), the OECD, the United Nations (UN), the Teachers Insurance and Annuity Association - College Retirement Equities Fund (TIAA- 
CREF), the combined International Corporate Governance Network and California Public Employees Retirement System (ICGN/CalPERS), and General Motors (GM). 


\section{Table 4}

Corporate governance codes

\begin{tabular}{|c|c|c|c|c|c|c|c|c|}
\hline \multirow{2}{*}{$\begin{array}{l}\text { Affiliation } \\
\text { Author }\end{array}$} & \multicolumn{3}{|c|}{ Stock exchange } & \multicolumn{2}{|c|}{ Government } & \multicolumn{2}{|c|}{ Shareholder } & \multirow{2}{*}{$\begin{array}{l}\text { Co. } \\
\text { GM }\end{array}$} \\
\hline & NZSC & NYX & ASX & OECD & UN & $\begin{array}{l}\text { TIAA- } \\
\text { CREF }\end{array}$ & $\begin{array}{l}\text { ICGN/ } \\
\text { CaIPERS }\end{array}$ & \\
\hline \multicolumn{9}{|l|}{ Company objectives } \\
\hline Disclose objectives & & $\checkmark$ & & & $\checkmark$ & $\checkmark$ & $\checkmark$ & $\checkmark$ \\
\hline Formal charter & $\checkmark$ & & $\checkmark$ & & $\checkmark$ & & & $\checkmark$ \\
\hline \multicolumn{9}{|l|}{ Ethical standards } \\
\hline Conflicts of interest & $\checkmark$ & & & $\checkmark$ & $\checkmark$ & & & \\
\hline Fair dealing & $\checkmark$ & & & $\checkmark$ & & & & \\
\hline Legal responsibilities & $\checkmark$ & & $\checkmark$ & $\checkmark$ & & & $\checkmark$ & \\
\hline Independent judgment & & & & $\checkmark$ & & & & \\
\hline Confidentiality & & & & & & & & $\checkmark$ \\
\hline Fully informed & & & & $\checkmark$ & $\checkmark$ & & & $\checkmark$ \\
\hline Diversity policy & & & $\checkmark$ & & & & & \\
\hline Director loans & & & & & $\checkmark$ & $\checkmark$ & & $\checkmark$ \\
\hline Setting the ethical tone & $\checkmark$ & $\checkmark$ & $\checkmark$ & $\checkmark$ & $\checkmark$ & $\checkmark$ & $\checkmark$ & $\checkmark$ \\
\hline \multicolumn{9}{|l|}{ Board composition } \\
\hline Director appointment & $\checkmark$ & & & & & $\checkmark$ & $\checkmark$ & $\checkmark$ \\
\hline Director independence & $\checkmark$ & $\checkmark$ & $\checkmark$ & & $\checkmark$ & $\checkmark$ & $\checkmark$ & $\checkmark$ \\
\hline Independent chair & $\checkmark$ & & $\checkmark$ & & & $\checkmark$ & $\checkmark$ & \\
\hline Retirement age & & & & & & $\checkmark$ & & $\checkmark$ \\
\hline $\begin{array}{l}\text { Limit to number of } \\
\text { directorships }\end{array}$ & & & & & & $\checkmark$ & $\checkmark$ & $\checkmark$ \\
\hline No role for former CEO & & & & & & & & $\checkmark$ \\
\hline \multicolumn{9}{|l|}{ Board practice } \\
\hline $\begin{array}{l}\text { Attendance at board } \\
\text { meetings }\end{array}$ & & & & & & $\checkmark$ & $\checkmark$ & $\checkmark$ \\
\hline Role in strategy & $\checkmark$ & $\checkmark$ & & & & $\checkmark$ & $\checkmark$ & $\checkmark$ \\
\hline Board evaluation & $\checkmark$ & $\checkmark$ & $\checkmark$ & $\checkmark$ & $\checkmark$ & $\checkmark$ & $\checkmark$ & $\checkmark$ \\
\hline
\end{tabular}

For presentation purposes the codes have been grouped by the affiliation of their author, i.e. stock exchange, government body, shareholders and company. This highlights how the nature of the organisations promoting the code influences its content. Shareholder organisations 
emphasise board composition and board practice, government organisations focus on ethical issues, and stock exchanges tend to keep their codes to the minimum. The content of the codes themselves has been divided into four categories: company objectives, ethical standards, board composition and board practices. This table is not definitive and some of the codes address other issues, many of which are of particular importance to the sponsoring organisation; for example, the CalPERS code includes clauses requiring companies to report on greenhouse gas emissions.

This structure reveals some common themes across governance codes, including:

- Ethics. Each of the corporate governance codes reviewed in Table 4 specified that the board is responsible for setting the ethical standard and tone for the business. This highlights a gap between these stakeholders' expectations of boards and the corporate governance literature, given that none of the definitions of the boards' role identified in Table 2 consider setting an ethical standard to be a primary board responsibility.

- Board composition. With the exception of the OECD all the governance codes promoted the role of independent directors, and $50 \%$ of the codes (including the two US-based pension funds) also advocated independent chairs. This shows strong support for the concept of independence, notwithstanding the lack of evidence to support a tangible link between director independence and firm performance.

- Board practice. This is the area that is the least specified in the codes reviewed. This suggests that the codes' advocates are still keen for directors to have the freedom to set their practices to meet the challenges of their businesses as they 
see fit. The shareholder codes and most of the stock exchange codes single out strategy as an area that boards should focus on. These codes all propose that the role of the board is to review, approve and guide, but not to develop corporate strategy.

- Outliers. Some corporate governance codes are alone in highlighting certain areas of governance. The ASX is alone in advocating that companies establish a gender diversity policy and report annually on progress towards achieving this objective (ASX, 2007). Surprisingly neither the OECD nor the UN codes raise the issue of gender diversity. The OECD code is unique in not advocating that all directors should be able to exercise independent judgement on corporate affairs (OECD, 2004). The shareholder sponsored codes are mindful of the time commitment that being a director requires and recommend a limit to the number of directorships that an individual can hold.

The key point that Table 4 illustrates is that these organisations all have different expectations of boards. The table shows that these codes are like manifestos, in that they appear to be an attempt by the sponsoring organisation to exert a degree of compliance with their views over companies within their investment spheres. For example, companies that want to attract some of the US $\$ 370$ billion that the US-based TIAA-CREF have under management must adhere to their code. The TIAA-CREF code includes guidelines for environmental and social issues that are not often found in other codes, but which probably reflect the views of their clients (Gregory, 2008). The OECD (2004) and UN (2006) codes also reflect the nature of their sponsoring body, as both of these codes place a heavy emphasis on the legislative aspects of governance and ensuring a level playing field where shareholders' rights are respected. The NYX code appears to be written from a company directors' perspective; it is unique among the codes discussed in recognising that governance is not the sole domain of boards, and it 
emphasises the role and responsibilities of both shareholders and management in the overall governance process. NYX considers that 'the critical role of management in establishing proper governance has not been sufficiently recognised', and shareholders, it says, 'have the right, the responsibility and a long-term economic interest to vote their shares in a thoughtful manner' (NYX, 2010, p. 3). Another area where NYX is at odds with the other codes is that it cautions against having only one executive on the board; its concern is that boards with a sole executive may lack the required in-depth knowledge of the company (NYX, 2010). The GM code appears to be designed to attract as many investors as possible, presumably to ensure a strong share price. It incorporates some unusual and potentially provocative ideas; for example, in an uncontested appointment election a director must still receive $50 \%$ of votes cast or stand down. Directors must, after an initial period on the board, own a minimum of $\$ 300,000$ in GM shares. Presumably the idea behind this is that directors will have enough equity at risk to encourage hard work and entrepreneurship, but not so much as to drive them towards purely defensive strategies that favour equity preservation. The NZX has the most minimal code of all of those discussed (NZX 2012). It recommends that boards establish an ethics procedure, a series of subcommittees, and a relationship that is independent of management with the firm's auditors. It is difficult to see how this would in any way alter the behaviour of New Zealand's listed companies.

Overall these codes show some distinct differences in perspectives of different stakeholder groups and they highlight some of the issues that influence these stakeholder groups' expectations of boards. 


\subsubsection{Board self-evaluation}

Lord Halifax's observation on how British boards 'mark their own examination papers', noted in the introduction, predates the recent penchant for board evaluation, but his comment still holds true: boards continue to evaluate themselves. The concept of formal board self-evaluation has its origins in the wider debates of the 1990s that centred on how to improve overall corporate governance by making boards more effective, engaged and accountable (Long, 2006). The concept of board self-evaluation has since been incorporated in a number of corporate governance codes (Table 4). However, this push for board evaluation has been diluted somewhat by directors, who have generally resisted such demands and ensured that these guidelines and regulations stipulate only that some form of director self-evaluation process be performed (Long, 2006). The codes themselves do not specify the evaluation criteria, nor do they require the board to disclose the results of the evaluation, so it is difficult to tell how committed directors and boards are to this process.

Based on the adage 'you are what you measure' (Ariely, 2010), an examination of the central themes of these methodologies may provide an indication of the issues and features of boards that directors consider important and therefore influence their expectations of boards.

Some of the proposed methodologies for board self-evaluation are based on checklists (Kiel \& Nicholson, 2005; Kuprionis, 2011). For the most part these checklists focus on soft skills, such as leadership, teamwork and communications skills, rather than on easily measurable 'hard' outcomes, such as company financial performance and specific objectives. This raises a question: to what extent do directors consider themselves responsible for their company's financial performance? Others argue that a checklist approach is overly simplistic and fails to take into account the dynamics involved in the boardroom (Ingley \& Van der Walt, 2002; Huse, 2005). For those that don't favour checklists the Montreal Bank's director 
evaluation process is often cited as an exemplary model of evaluation, with its directors performing full 360-degree evaluations on each other (Comper, 2001). It is significant that the Montreal Bank's approach, like many of these checklist-style evaluation methodologies, also focuses on soft skills, rather than the more measurable 'hard' outcomes. A New Zealand selfevaluation tool that is an extension of the checklist approach was developed by Northcott and Smith (2011). Their tool is unusual among those published in that it places an emphasis on EVA, ROI and share price factor. Overall, the board self-evaluation methodologies suggest that directors' expectations of boards are influenced by the personal attributes of their fellow directors.

\subsubsection{External corporate governance rating systems}

Between comprehensive company reporting regimes, continuous disclosure requirements and myriad informal communications channels, such as investor newsletters and shareholder-driven internet forums, shareholders have access to a wide range of information from which to access the quality of governance of any particular company. In spite of, or perhaps because of, this abundance of information, in the US and elsewhere an industry has developed that supplies corporate governance rating data for publicly listed company boards. The largest governance rating firm, International Shareholder Services (ISS), assesses corporate governance practices by focusing on the following areas: board structure and composition, audit issues, charter and by-law provisions, laws of the state of incorporation, executive and director compensation, qualitative factors, director and officer share ownership, and director education (ISS, 2012). The effectiveness of the ISS ratings as a predictor of future equity value is debateable (Brown \& Caylor, 2004; Daines, Gow \& Larcker, 2009; Donker \& Zahir, 2008); however, given that investors pay for the data it may provide a pointer towards the characteristics that investors value in boards. 
ISS's methodology is based on eight key attributes that it credits with influencing the quality of corporate governance (Donker \& Zahir, 2008); the majority of New Zealand companies adopt the same position on most of the attributes, either because of regulation or due to convention. For example, all New Zealand companies have separated the functions of chairman and CEO. Two attributes that ISS includes in its evaluation methodology and which are relevant in the New Zealand context are the size of the board and the number of independent directors. It is possible therefore that these are two attributes that New Zealand shareholders consider important in their expectations of company boards.

\subsection{Director Attributes}

Given that boards are composed solely of directors it is likely that attributes of individual directors influence both shareholder and director expectations. For example, directors with a finance background are likely to have expectations regarding the board's involvement in financial matters. Although directors have been the subject of much research, there is little consensus on who makes a good board member (Johnson, Schnatterly \& Hill, 2013). This section examines several attributes of directors that are easily observed by both directors and shareholders and are therefore likely to influence their expectations of directors and boards. The attributes are: director independence, executive directors, busy directors, women directors, celebrity directors, director tenure, and director human capital. These attributes have also been comprehensively researched, arguably because they are easily measured (Gabrielsson \& Huse, 2004). 


\subsubsection{Independent directors}

'Independent directors are like bidets - no one knows what they are for but they add a touch of class.' So says former chairman of the BBC Michael Grade (Garratt, 2004 p. 69). While Grade's comment is somewhat facetious, the reality is that 'independent director' is another governance term that does not have a single or commonly held definition. Even within the narrow field of European corporate governance codes, there are some 37 unique definitions (Berghe \& Baelden, 2005). To further complicate the issue, terms such as 'independent', 'outside', 'non-executive' and 'non-employee director' are often used interchangeably. Choosing not to define the term can create other problems because not only is the term used in different ways but conclusions based on one assumed definition are often inappropriately applied in other contexts (Clarke, 2007).

At its simplest, an independent director is any director who is independent of management and is elected by the shareholders (Brudney, 1982). Another common concept of the independent directors is the director who acts in the public interest and is independent of everyone including management, major shareholders and anyone else with a material interest in the company. This is the definition that the NZX has adopted (NZX, 2013, section 1.6).

Regardless of the definition adopted, the main argument in favour of independent directors is that their presence on boards counterbalances the power of management and further protects shareholder interests by reducing the chances of damaging conflicts of interest both with management and with major shareholders and their board appointees (Crespí-Cladera \& Pascual-Fuster, 2014; NYSE, section 303A, 2012; Donaldson \& Davis, 1994). There are also arguments that because independent directors are less tied to management and their vision they are more inclined to make decisions that will increase shareholder value as measured by share price (Gordon, 2007). Others argue that independent directors are able to objectively evaluate 
senior management, review the business strategy and oversee the role of the auditors (Larcker \& Tayan, 2013, p. 143; Lipton \& Lorsch, 1992).

A weakness associated with the independent director concept is that, in practice, independent directors may not act in a truly independent manner. This is because a director with limited tenure who enjoys the role is likely to feel responsible to whoever appointed them (Clarke, 2007). It is also argued that social ties between independent directors and CEOs, can, for better or worse, limit the ability of independent directors to act truly independently (Westphal, 1999). To address this issue researchers increasingly are turning their attention to some of the 'softer' aspects of independence, and the term 'independence of mind' is entering the lexicon (Berghe \& Baelden, 2005).

In spite of the strong arguments in support of independent directors there is extensive evidence to show that there is, at best, no correlation between directors' independence and firm performance (Agarwal \& Knoeber, 1996; Bhagat \& Black 1998). Some researchers claim there is a negative correlation between independent directors and company performance (Donaldson \& Davis, 1994; Hossain, Prevost \& Rao, 2001; Gordon, 2007). A possible explanation for these disappointing findings can be traced back to Adam Smith, who argued that the lack of a director's financial commitment to a firm reduces their alignment with shareholder objectives (Smith, 1776). It can also be argued that, when faced with a risky but potentially lucrative opportunity, independent directors are unlikely to support the opportunity, irrespective of the objectives of the shareholders. This is because in this scenario they have little to gain financially but would be placing their most valuable asset, their reputations, at risk (Ong \& Wan, 2008).

Regardless of the actual value that independent directors add to the companies they serve, US shareholders certainly value independent directors. When analysing the impact on 
share price of the sudden death of independent directors, Nguyen \& Nielsen (2010) discovered that on receiving the news of such a death, the value of the firms associated with the recently departed director dropped by an average of $\$ 35 \mathrm{M}$.

\subsubsection{Busy directors}

The vast majority of directors sit on just one public company board (Larcker \& Tayan, 2013). Directors who sit on multiple boards are frequently referred to as 'busy directors'. Busy directors are seen as adding value to boards through their in-depth knowledge and experience of public company governance (Field, Lowry \& Mkrtchyan, 2013) and through their connectivity to other directors and executives (Kor \& Sundaramurthy, 2008). Others suggest that busyness certifies a director's ability; as the saying goes, 'if you want something done give it to a busy person' (Cashman, Gillan \& Jun, 2012). Busy directors are also seen to have limitations, as they are sometimes considered to be ineffective monitors of company performance (Fich \& Shivdasani, 2006).

Research into the effectiveness of busy directors on overall company performance has produced mixed results, with some research finding that busy directors have a positive effect on firm performance (Ferris, Jagannathan \& Pritchard, 2003), others finding that busy directors have a detrimental effect (Fich \& Shivdasani, 2006; Core, Holthausen \& Larcker, 1999), and some finding mixed results (Cashman et al., 2012; Field et al., 2013). Regardless of the actual impact that busy directors have on company performance it is likely that both directors and shareholders will have opinions on the impact of busy directors and hence it will influence their expectations of boards. 


\subsubsection{Women on boards}

Women tend to be under-represented on corporate boards worldwide. In a 2007 review of 42 countries, the number of women directors ranged from a high of $22 \%$ in Slovenia down to just $0.2 \%$ in Japan (Terjesen \& Singh, 2008). However, in many countries this is changing and the number of women directors is slowly increasing. In some countries the increase is being driven by government policy - for example, both Sweden and Norway have set minimum quotas for women on public company boards. Norway now mandates that a minimum of $40 \%$ of seats on corporate boards be held by women (Wang \& Kelan, 2013). The European Commission (EC) has recently followed the Norwegian lead; in November 2012 it set an objective (to be achieved by 2020 ) that $40 \%$ of non-executive directors of substantial public companies should be women. This is more than a simple act of appeasement or an aspirational target, as the EC proposal is backed by a requirement that member states apply sanctions to companies who do not achieve this minimum threshold (Sealy \& Vinnicombe, 2013). Pressure is also being applied to increase the number of women directors in many other western countries such as the US (Dobbin \& Jung, 2010). In New Zealand the Ministry of Women's Affairs is actively engaged in lobbying businesses to increase the number of women directors by sponsoring organisations such as Women on Boards. All this activity makes the presence of women on boards one of the most prominent issues currently within the corporate governance domain.

Given that the number of women on boards is increasing, an important questions is: "what is the likely impact of this increase on both board and company performance?" Unsurprisingly, the results are mixed, with some studies finding a positive link (Carter, D’Souza, Simkins \& Simpson, 2010) and others suggesting a negative impact on firm value (Adams \& Ferreira, 2010). There is also the suggestion that women are appointed to the boards of successful companies as 'tokens' (Burgess \& Tharenou, 2002). Increasingly the debate is 
moving away from finding a direct link between the gender of directors and firm performance towards behavioural differences between the way men and women operate in small group situations such as board meetings. The argument in favour of gender diversity revolves around the idea that it allows groups to come to better decisions more quickly (Nielsen \& Huse, 2010), while the opposing argument holds that gender differences can lead to conflict in small groups, which in turn leads to less effective decision making (Jackson, Josi \& Erhardt, 2003). There appears to be no obvious consensus emerging in this debate and it seems likely that it will continue for some time.

From a shareholder and director perspective an important question is: "why are women being appointed to boards?" Are women being appointed because of their ability to contribute to the board and the long-term success of the company or for other reasons? Given that there is no obvious link between company performance and the appointment of women it is possible that boards are aware of this and are looking for other benefits from women directors. One of the key non-financial benefits of having women on boards is their contribution to the company's reputation (Burke, 2003). It has also been argued that directors encourage the appointment of women because they believe that it will please institutional investors (Dobbin \& Jung, 2007). Given that in the US institutions control some $80 \%$ of shares and their institutional investors are active in governance such action would be both rational and understandable (Gillian \& Starks, 2000).

\subsubsection{Celebrity directors}

A celebrity in this context is a person who enjoys wide public recognition (Cardow \& Wilson, 2015). Celebrity directors have long been a feature of corporate boardrooms. It is argued that their appointment is seen as an endorsement of the future prospects of the company (Fich, 
2005). In the US it has been observed that the appointment of a celebrity to a board coincides with a jump in stock price and that this improved share price performance relative to companies that lack celebrity directors is maintained in the long run (Ferris, Kim, Nishikawa \& Unlu, 2011). This is curious given that most celebrities are not known for their business acumen. Ferris et al. assume that this improved performance could be attributed to celebrities making firms more visible, which in turn results in increased analyst coverage and increased institutional ownership, which, they argue, results in increased share prices. Celebrity directors can also endorse the company's product, which in turn can lead to greater sales.

An example of this in New Zealand is found in the publicly listed finance company Lombard. The founding directors included three former Ministers of the Crown, two of whom were likely ranked as some of the most trustworthy people in New Zealand, and the company relied on endorsements from these directors to sell their investment products. The strategy was, for a time, very successful, although the firm subsequently failed (Cardow \& Wilson, 2015). The failure of the Lombard finance company was attributed to a failure of governance and the board was subsequently convicted of a number of securities-related offences ( $R$ vs Graham, 2012). The court cases surrounding the failure have received widespread publicity in the mainstream media (Rutherford, 2012) and may therefore have influenced both directors' and shareholders' expectations of boards.

\subsubsection{Director tenure}

The duration of a directorship and the amount of time board members have served together are both metrics that are publicly available, and the question of what is an appropriate tenure for a director periodically arises in the popular press (Gaynor, 2014). As a result it is a topic that is likely to influence both directors' and shareholders' opinions of boards. 
There are advantages and disadvantages of boards serving together for a long time, as Forbes and Milliken (1999) have identified. As board members notch up time together, they can acquire a high degree of firm-specific knowledge, as well as a high degree of cohesiveness. This cohesiveness can also lead to a lower degree of cognitive conflict, because in working together the directors have developed a shared understanding of the challenges facing the company and the likely responses. Similar arguments are made around the tenure of individual directors. Those in favour of long-tenured directors suggest that they have greater engagement with the company because of their greater expertise and knowledge of the firm (Vafeas, 2003). Those against long-tenured directors claim they simply run out of new ideas and that, over time, directors become less demanding of management (Canavan, Jones \& Potter, 2004).

\subsubsection{Executive directors}

The relationship between management and the board is considered one of the key elements of corporate governance (Moltz, 1985, p. 87; Cadbury, 1992, section 2.5; OECD, 2004, p. 24). Executive directors are company employees who sit on the board (Fama \& Jensen, 1983). Initially all directors were also executives, but over time executive directors have progressively given way to independent directors. In the US, for example, the number of independent directors increased from $20 \%$ in 1950 to $75 \%$ by 2005 , largely as a result of executives being displaced (Gordon, 2007).

The arguments in favour of having executive management on the board are supported by those who favour the board taking a more active role in the affairs of the company (Cadbury, 1992, section 4.2). The arguments against having an executive presence on the board are led by those who see the board as primarily a control mechanism to protect shareholders from management opportunism (Macey, 2008). The presence or otherwise of executive 
directors can also be seen as a measure of the relative power between the board and management (Fama \& Jensen, 1983). One area where this manifests itself is in the appointment of new directors. Westphal \& Zajac (1995) observed that influential CEOs were able to persuade boards to appoint independent directors that were demographically similar to themselves. This, they observed, calls into question the commonly held assumption that independent directors are more likely to exhibit independent judgement in board decision making.

\subsubsection{Director human capital}

Human capital, from a governance perspective, comprises the personal skills and experiences that individual directors contribute to the board (Johnson et al., 2012). The literature acknowledges the influence that a director's background and experience can have over a company and its performance (Westphal \& Fredrickson, 2001), but, as with many of the other aspects of governance, multiple research studies seldom produce consistent results. Based on Singh, Terjesen \& Vinnicombe's (2008) taxonomy, the human capital of directors has been examined from the following perspectives: education, commercial and professional experience, and previous board experience.

\section{Education}

Education is thought to affect directors' decision making, and it is argued that advanced education is a starting point for the independent thinking that is required by directors (Singh et al., 2008). Some of the research linking directors' educational qualifications to company performance has failed to find a link (Daily \& Dalton, 1994); but in the case of independent directors, a positive link has been identified (Kim \& Lim, 2010). It is also possible, although not specifically identified within the literature, that advanced qualifications or qualifications 
from prestigious universities may add to a director's social capital, which in turn could influence both directors' and shareholders' expectations.

\section{Commercial and professional experience}

Previous industry experience, financial expertise, and experience as a CEO all have the potential to influence director and shareholder expectations of boards. For example, directors with these attributes may be considered to 'know what they are doing' from a shareholder perspective. Directors with previous industry experience have generally been found to benefit the companies they are associated with (Kor \& Sundaramurthy, 2008). Financial expertise has proved difficult to precisely define, so its boardroom benefits are not well understood (Johnson et al., 2012). However, in the US there has been a significant increase in the number of directors with a financial background, so presumably either directors or shareholders place a value upon it (Chhaochharia \& Grinstein, 2007). CEOs of outside firms are frequently appointed to boards. One of the key benefits they bring is a certification benefit for the appointing firm (Fahlenbrach, Low \& Stulz, 2010), which suggests that they influence shareholder expectations.

\section{Previous board experience}

The degree of governance experience that directors have acquired prior to joining their existing boards is not well understood, possibly because such data cannot be easily obtained. There is, however, evidence to suggest that previous governance experience is valued by both directors and shareholders alike. For example, companies listing on stock markets for the first time tend to appoint independent directors who have previous governance experience (Chahine, Filatotchev \& Zahra, 2011).

\subsection{Summary}


When examining the corporate governance literature discussed in this chapter as a whole, the central theme that emerges is that there is little conformity around most of the aspects of corporate governance investigated. The review has shown that there is little consensus regarding the purpose of corporate governance and of the role of the board. In the absence of general agreement, the literature very quickly forks into multiple paths. For example, the principal theories employed to either explain or predict corporate governance behaviour appear to be based on different underlying assumptions regarding the purpose of corporate governance. Different countries have adopted different approaches to corporate governance, which adds further complexity. Even those countries that have adopted a common approach, such as the Anglo-Saxon model, have been shown to exhibit significant differences in the way that they practise corporate governance. Within countries corporate governance practices further fragment, with different companies appearing to adopt different approaches to many aspects of corporate governance (Boone et al., 2007). This raises considerable challenges for researchers, who must select from the wide range of theories available in order to apply the most appropriate theory for any given situation. (Daily et al., 2003).

The open-system nature of corporate governance may contribute to this complexity as environmental factors outside of the immediate governance domain appear to influence governance practices (Aguilera et al., 2008). This raises the possibility that directors and shareholders who have different exposure to these environmental factors may have different expectations of boards. Although the literature reviewed does not yield clear insights into shareholders' and directors' views and expectations of boards, it has helped to illuminate factors that are of particular interest to shareholders and directors, and which may influence their expectations. 


\section{RESEARCH ENVIRONMENT AND METHODOLOGY}

This chapter presents the research question: “what do New Zealand's shareholders and company directors expect from New Zealand's public company boards?" and some supplementary questions. It then discusses why a traditional corporate governance research methodology would be unlikely to yield full answers to these questions, and hence the requirement for an alternative research methodology. The methodology employed is then discussed. Finally the ethical considerations and the limitations of the research are detailed.

\subsection{Primary Research Question}

The principal question the research seeks to answer is:

What do New Zealand's shareholders and company directors expect from New Zealand's public company boards?

The literature review (Chapter 2) has highlighted some important aspects within this question that must be taken into consideration when formulating an answer. Specifically the literature suggests that external environmental factors may have a significant influence on both shareholders' and directors' expectations of boards (Aguilera \& Jackson, 2003; Finkelstein \& Mooney, 2003). The opinions and expectations of shareholders and directors are likely to be aligned on some issues but not others. This can be illustrated graphically, as shown in Figure 1. 


\section{Figure 1}

Conceptual model of the corporate governance environment

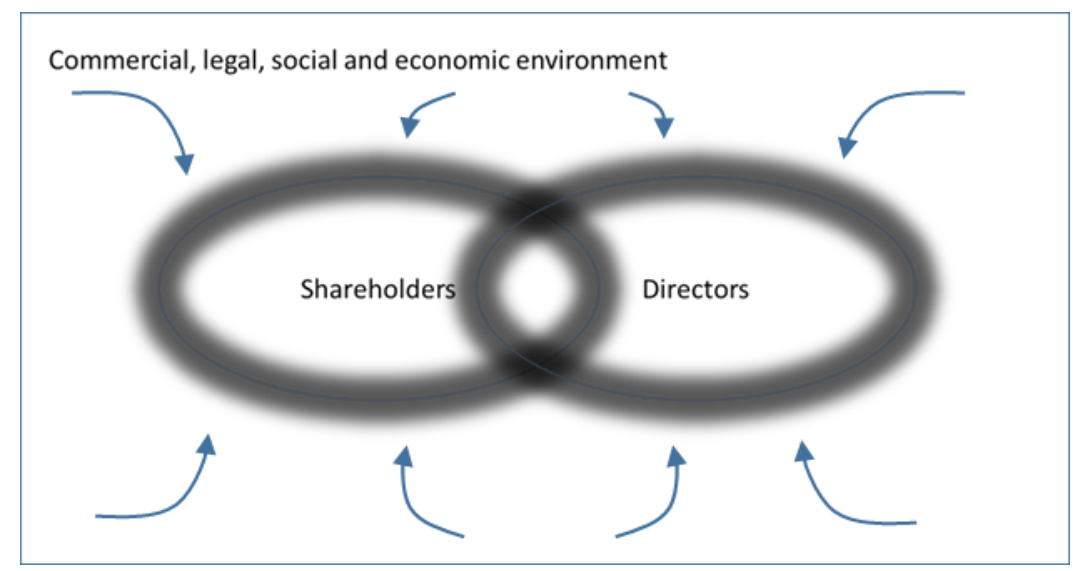

The rectangle represents the environment in which corporate governance is practised. One of the challenges of this research is to identify those environmental factors that might have a material impact on the behaviour of shareholders and directors and thus should be included within the rectangle, and to exclude those that don't. The fuzzy ellipses surrounding both shareholders and directors illustrate the potential lack of homogeneity within these groups. The research will also assess the degree of homogeneity that actually exists within these stakeholder groups; this is important because, as was shown by the Cadbury case study in Chapter 1 , differences between group members' expectations of boards can sometimes have serious consequences. Equally important is the extent to which there is conformity between the views of shareholders and directors, so the research will identify issues on which the two groups generally agree and issues on which they generally disagree.

In order to fully address the research question it is necessary to answer the following supplementary questions: 
1. How heterogeneous are the shareholders and directors in their expectations of NZ boards?

2. As groups, how homogeneous are shareholders in their expectations of boards, and how homogeneous are directors in theirs?

\subsection{Addressing the Traditional Corporate Governance Research Limitations}

As discussed in 2.5.1, the most common approach to corporate governance research is to treat the board as a 'black box', with inputs drawn from public data sources and outputs measured as financial performance metrics (Gabrielsson \& Huse, 2004). These ‘black box' studies, however, are not without their limitations as they are frequently criticised for failing to take into account the contingent nature of corporate governance or the influence of environmental factors on corporate governance (Aguilera \& Jackson, 2003; Finkelstein \& Mooney, 2003). The approach taken in this research has been designed to mitigate as much as practicable these limitations.

\subsection{Research Methodology Overview}

This research is exploratory in nature in that its objective is to gain an understanding of the expectations of shareholders and directors. Its intention is not to solve any specific problem or prove or disprove any particular theory. However, by gaining this understanding of shareholders and directors expectations evidence will be obtained that will likely support or refute elements of the current body of corporate governance literature. Because of the exploratory nature of the research it can be expected that the findings will also highlight areas where future, more conclusive research, may be required. In this respect, the research may also 
assist in determining future research design, sampling methodologies and data sources and collection methods (Singh, 2007, p.64).

A relativist ontology has been adopted for the research. This assumes that there are no universals and that truth is determined through a consensus between different viewpoints and that facts are dependent on the viewpoint of the observer (Easterby-Smith, Thorpe \& Jackson, 2008 p.62). This ontology has influenced the design of the research methodology in two ways. Firstly it has created a requirement for the research to capture the viewpoints of a wide a range of shareholders and directors from as many different perspectives as is possible, and secondly it has created a requirement to take into consideration the background, perspective and expectations of the author in respect to corporate governance (see 3.7). As will be shown in this section, these two requirements have added considerable complexity to the research methodology.

A relativist epistemology has also influenced the approach adopted. This epistemology has created a requirement for the research to be designed to ensure that the question is approached from multiple perspectives and to triangulate amongst the various perspectives in order to identify any consensus Easterby-Smith et. al. (2008 p.63). This has been achieved by developing a series of individual but complementary research initiatives many of which draw on different data sets and use different research techniques. Particular care was taken to ensure that, wherever possible, sufficiently large samples were collected to ensure that the results have credibility. Where small samples have been taken this has been clearly identified.

In order to obtain the wide range of perspectives required for this approach it was necessary to adopt a mixed methods approach. The fundamental principle of mixed methods research is to collect multiple data using different strategies, approaches, and methods and to do so in such a way as the resulting mixture or combination results in complementary strengths 
and non-overlapping weaknesses Johnson \& Turner (2003). The methods adopted include surveys, focus groups and content analysis of data derived from secondary sources.

The specific approach adopted for this research involves expanding on the traditional black box approach to take into consideration external environmental factors and by engaging directly with company directors. This is achieved by dividing the research into a series of linked phases. Table 5 provides a summary of the objectives of each phase of the methodology.

\section{Table 5}

Research methodology objectives

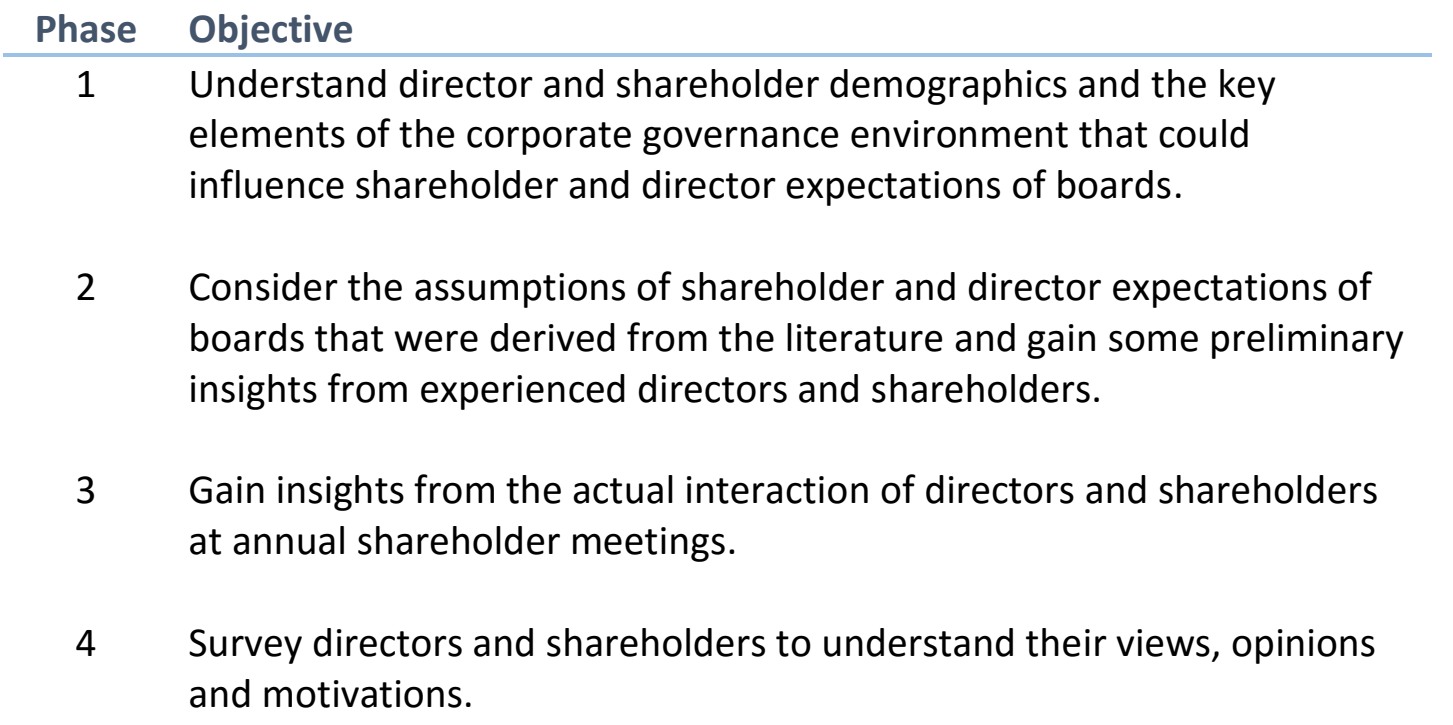

The phases as outlined in the table can be further explained as follows:

- Phase 1. Director and shareholder demographics, and an environmental assessment. This involves collecting data from a wide range of secondary sources including company annual reports, the companies office directors database, Reserve Bank statistics and NZX data in order to develop a basic understanding of shareholders, directors and the environment in which they 
operate. This is effectively treating the board as a 'black box' but enhancing the traditional methodology by using a far wider range of input data than are typically acquired in such research (Daily et al., 2003). This phase also takes into consideration some of the external environmental factors and some historic trends, as the additional data can assist in addressing Aguilera \& Jackson's (2003) criticism that such research fails to take into account the dynamic and contingent nature of corporate governance.

- Phase 2. Focus groups. Focus groups are conducted with shareholders and directors. The objective is developmental and the focus groups are conducted to ensure that the relevant issues are identified so that the Phase 4 written survey can address them in more detail.

- Phase 3. ASM minutes analysis. Evaluating direct interaction between shareholders and directors at company ASMs provides not only some unique insights into the question, but also more data to refine the content of the Phase 4 survey.

- Phase 4. Postal survey. Directors and shareholders were surveyed directly for their opinions.

\subsection{Director, Shareholder and Environmental Influences on the Research Methodology}

Before discussing the detailed approach to the research it is necessary to gain an understanding of the three key elements in the research: the environment, the shareholders, and the directors. Each presents challenges that must be considered when developing a research methodology 
capable of addressing the primary research question. This section addresses each of these factors.

\subsubsection{External environment}

There is a wide range of external factors with the potential to influence both shareholders' and directors' expectations, some of which have been previously identified in the international literature (e.g. Aguilera et al., 2008; Davies \& Schlitzer, 2008). This research will explicitly focus on the legal and commercial environments and on political and social trends from the wider community that appear to have an immediate and direct impact on directors' and shareholders' expectations of boards. Most of the factors were included because they have been identified in the international literature as potential influences on board behaviour. These influences are outlined below.

- Legal environment. Research has been conducted into the influence of the legal environment on various countries' corporate governance practices (La Porta, Lopez-de-Silanes \& Shleifer, 1999 and 2006). While there are numerous laws and regulations that affect the way boards operate, this research focuses primarily on company law, securities law and NZX listing rules. These laws and rules directly affect both shareholders and directors and therefore have a direct influence on their expectations of boards. One other law - the NZ Health and Safety in Employment Act 1992 - is considered, for two reasons. Firstly, it contains severe penalties, including incarceration, should directors not comply with certain clauses contained within it. Given the severity of the potential consequences for noncompliance, it is assumed that this Act would also influence director behaviour. Secondly, the Act is comparatively new and it 
therefore provides an insight into how quickly boards respond to outside influences.

- Commercial environment. Aspects of the commercial environment have been shown to influence board behaviour, for example, the market for corporate control (Jarrell et al., 1988) and the role of the banking sector (Rosen, 2007). They are likely to influence NZ shareholders and directors and so have been considered in this research.

- Political and social influences. Directors are subject to the broad political and social influences and trends from outside of the boardroom. Two issues will be considered: the role of women on boards and the role of overseas-based directors. The role of women is considered because, as was shown in section 2.6.3, this is the main social and political factor currently influencing board behaviour in New Zealand. The role of overseas investment in general is a topic that is currently being debated in the broader community (Raziq \& Perry, 2012), but to date this debate has not included the role of overseas directors in New Zealand's public companies. Including the topic will provide an opportunity to lead the debate and to contribute to an area that has not been previously researched in New Zealand.

- Company issues. Some characteristics of the companies themselves may influence the way boards operate and the expectations of both shareholders and directors. For example, the size of a company will influence the amount of resources that can be dedicated to the boards and to the qualifications and experience of the directors that the company can attract. Probably the most significant factor influencing director and shareholder expectations is the degree 
to which ownership of a company is dispersed and control is centralised, as identified by Berle \& Means (1932). Current data on the ownership and control of New Zealand companies is not available, so it was necessary to undertake some fresh research in this area.

A number of other external influences were considered for inclusion in the research. Most prominent among these is the influence of the Institute of Directors and the Shareholders' Association. In the course of this research meetings were held with the CEO of the IoD, the policy director of the Ministry of Women's Affairs, and the chair of the Wellington branch of the Shareholders' Association. Based on these meetings it was decided that insufficient resources were available to fully assess the indirect impact that these groups have on shareholders and directors.

Other environmental issues, such as the role of Maori investment companies and the role of government as an investor in public companies, were considered for inclusion in this research, but after an initial assessment were excluded. Maori companies were excluded because there are very few public company directors who identify themselves as Maori and attempts to track Maori investment in public companies proved unsuccessful. The government as an investor was not considered because of resource constraints and because, until the recent listing of several electricity companies, their direct participation in NZX-listed companies was relatively small. The one exception to this is the Accident Compensation Commission (ACC), which in practice acts in the same manner as other institutional investors (ACC, 2014). The government superannuation fund invests in the NZX equities indirectly through other institutional investors. 


\subsubsection{Directors}

Company directors are a challenging subject for any research, not least because researchers have found it almost impossible to observe boards in action (Daily et al., 2003). Indeed, even obtaining opinions directly from directors has proved difficult for many researchers (Leblanc \& Schwartz, 2007). As a result, most research focuses on the following demographic factors, which have been shown to likely influence directors' expectations of boards and governance (Van der Walt \& Ingley, 2003). These are: the number of directors (Reedy, Locke \& Scrimgeour, 2010), their experience (Goldfinch, 2004), their independence (Clarke, 2007), and the number of boards that each director sits on (Larcker \& Tayan, 2013). Research has also been conducted into directors' personal opinions and attitudes and expectations of boards; the techniques that were adopted to research these aspects and to overcome the access issues raised by Leblanc and Schwartz are outlined in section 3.5.1.

\subsubsection{Shareholders}

From a research methodology perspective the biggest challenges that New Zealand public company shareholders present is their diversity. Shareholders likely range from individuals with small investments and limited investment experience through to multinational corporations with highly experienced investment specialists and substantial portfolios. Chiu and Monin interviewed some New Zealand fund managers to gain their perspective on corporate governance (Chiu \& Monin, 2003) to my knowledge this is the only research that has been conducted regarding the expectations that any New Zealand shareholders have of any aspect of corporate governance. No research appears to have been conducted into the expectations of individual shareholders so there are no precedents on which to base this aspect of the research. The approach taken to identify a sample of this population and collect data regarding their expectations of boards is outlined in the following section. 


\subsection{Research Methods and Data Sources}

As shown in Table 5 the research is divided into four distinct phases: (1) understanding the New Zealand environment, (2) developmental focus groups, (3) ASM minute analysis, and (4) written surveys. This section discusses each of the phases, including the specific approach adopted, the reasons that certain factors were included and others excluded, and the limitations of each phase.

\subsubsection{Phase 1: Understanding the NZ environment}

While some data on shareholders and some key environmental factors such as the regulatory environment are available, the literature regarding director, and company demographics is incomplete. The objective of this phase of the research is to improve this situation so that the subsequent phases can be based on a thorough foundation. By drawing on data from a wide range of secondary sources such as company annual reports and stock exchange announcements, the Companies Office director database and the social media site Linkedin a more comprehensive and up to date view of the New Zealand public company environment is developed than is currently available. Some of the existing literature is updated and refreshed with recent data and new research is conducted to fill the key gaps that exist within this literature. Wherever practicable the existing research has adopted the same methodologies to allow long-term trends to be analysed.

\section{NZX companies}

A review of the literature showed four features of companies that have potential to influence directors' and shareholders' expectations of boards. These are ownership distribution and shareholder control, both of which were first flagged by Berle \& Means (1932), as well as board size (Koerniadi, Krishnamurti \&Tourani-Rad, 2014) and shared directors (Kor \& 
Sundaramurthy, 2008). Company size was not identified within the literature as a possible influence, but it has been included in this analysis because it may possibly influence the resources available to dedicate to shareholder communication and also influence the quality of directors. It is possible that other demographic features of NZ companies could influence director and shareholder expectations of boards, but, due to resource constraints and a lack of compelling evidence to justify their inclusion, no other features were included.

The approach to data collection and analysis for company-specific factors is as follows. The primary source of data for NZX-listed companies was the NZX website (NZX.com) and company annual reports. The reports were all sourced from company websites. All such information was collected in December 2013. The annual reports were the most current available at that date and all of those analysed had financial years that ended in 2013. Wherever possible, data were collected on all 112 companies. However, in some cases the sheer volume of data required to analyse all 112 companies was beyond the scope of available resources. In these situations, detailed data were collected for analysis from a randomly sampled subset of 40 companies. The sample size of 40 met the requirements of both the resources available to collect the data and the need for a sufficiently large sample to ensure an appropriate degree of confidence in the results of statistical tests employed (O'Leary 2010). The NZAX companies have been excluded from this analysis because of the market's relatively small size (its capitalisation is less than $1 \%$ of that of the main board) and because companies listed on this board are subject to less demanding rules than those on the main board. Table 6 summarises the approach to this section of the research. 


\section{Table 6}

Company research: data sources and size

\begin{tabular}{lll} 
& Data source & Sample size \\
\hline Company size & NZX website & 112 \\
Ownership distribution & Company annual reports & 40 \\
Control & Company annual reports & 40 \\
Board size & Company annual reports & 112 \\
Shared directors & Companies Office director database & 112
\end{tabular}

- Company size. Market capitalisation data were collected from the NZX website in December 2013 and some basic descriptive statistics produced.

- Ownership distribution. A premise of this research is that the greater the level of investment a shareholder has in a company, the more interested they are likely to be in the governance practices of the firm (Berle \& Means, 1932). Accordingly it is important to understand the distribution of share ownership. Previous studies (Hossain et al., 2001; Fox, Walker \& Pekmezovic, 2012) have focused on ownership distribution purely from a company control point of view and have not considered the potential influence that minority shareholders can have on board practices. They have not collected basic demographic data on shareholders, such as the number of shareholders and the size of their holdings, so their findings cannot be used as a starting point for this component of the research. The approach adopted involved taking a random sample of 40 of the 112 NZX main board companies and collating the shareholder distribution data published in their 2013 annual reports.

- Control. Previous studies of ownership of New Zealand listed companies have focused solely on the largest companies (Fox et al., 2012; La Porta et al., 1999) and have used a 
classification scheme that is not reflective of current business practices and has a number of weaknesses. For example, it is unclear if they have correctly accounted for custodial services companies. In addition, they do not differentiate between private, government and institutional shareholders who, as will be shown, all have different voting behaviours and exert different levels of control, which are not necessarily in proportion to their shareholding. To overcome these and other related limitations, fresh research was undertaken. The methodology adopted was to select a random sample of 40 NZX-listed companies and collect data from their 2013 statutory declarations. When considering these shareholders an adjustment was made to the statutory declaration data to exclude minor shareholdings held in aggregate by custodial services companies. This is because these organisations simply hold shares on behalf of other entities and they do not participate actively in the governance process. The data were then collated, and finally the controlling shareholders were identified and segmented by type (government, institution or private investor) and classified according to influence using Maume and Walker's (2012) taxonomy.

- Board size. Boyle and Ji’s (2011) data covering the period 1995 and 2011 were updated using data from the Companies Office director database. Data on all 112 NZX main board companies were obtained.

- Shared directors. The Companies Office director database provides data on every director, including information on every public company board of which they are a member. These data were collected and a network analysis performed to better understand the linkages between company boards. 


\section{Directors}

A review of the literature showed six demographic features of directors that have potential to influence directors' and shareholders' expectations of boards. These are executive directors and independent directors (Fama \& Jensen, 1983), director tenure (Mitchell, Fortmann \& Weiss, 2013), gender diversity (Fauzi \& Locke, 2012), busy directors (Kor \& Sundaramurthy, 2008) and director experience (Goldfinch, 2004). Where directors are domiciled was also included. While this is not currently an issue for New Zealand directors and shareholders, the issue of overseas investment in New Zealand is a contentious topic (Raziq \& Perry, 2012) and the debate may move to company boards, hence its inclusion. Other demographic features may influence shareholder and director expectations of boards, but resource constraints and a lack of compelling evidence restricted the research to these six features.

The primary source of data for directors was the New Zealand Companies Office director database (www.business.govt.nz/companies) and company annual reports. These reports were all sourced from company websites. All such information was collected in December 2013. The annual reports were the most current available at that date and all of those analysed had financial years that ended in 2013. Table 7 summarises the approach to these elements of the research. 


\section{Table 7}

Sources of data used in this research

\begin{tabular}{llc} 
& Data source & $\begin{array}{l}\text { Sample } \\
\text { size }\end{array}$ \\
\hline Executive directors & Company annual reports & 175 \\
Independent directors & Company annual reports & 417 \\
Tenure & Companies Office director database & 567 \\
Gender diversity & Companies Office director database & 567 \\
Domicile & Companies Office director database & 565 \\
Busy directors & Companies Office director database & 567 \\
Director human capital & Company websites, Linkedin, NZX website & 76
\end{tabular}

The specific methodologies adopted for each element of this research are discussed as follows:

- Independent and executive directors. Companies are obliged to lodge statutory declarations with NZX stating which directors are independent. These data were collected in December 2013 and the results collated. Executive directors were identified from information published in company annual reports at the same time.

- Tenure and gender diversity. This information was obtained from the Companies Office director database. A limitation of this data source is that it only shows current directorships. There is no information on previous positions held, so it is not possible to calculate a director's total experience as a public company director. However, this shortfall has been addressed in part in Phase 3 of the research. Data on all 567 directors serving as directors of companies listed on the main board of the NZX in December 2013 were collected and basic descriptive statistics produced. 
- Domicile. The research into directors' domicile involved collecting director addresses from the Companies Office director database and collating the data. Data on all but two of the 567 directors serving on the boards of NZX-listed companies in December 2013 were collected and collated. In spite of a legal obligation for directors to disclose their addresses the two directors had chosen not to and were therefore excluded from the analysis. To the author's knowledge, this data has not previously been collated and published.

- Busy directors. Data were also sourced from the Companies Office director database and analysed to show the number of directors holding multiple board seats. Data on all 567 directors were analysed.

- Human capital. This research uses publicly available data to understand the backgrounds and experience of all directors appointed in 2013. Data on 10 human capital characteristics were collected using a taxonomy based on that employed by Singh, Terjesen \& Vinnicombe (2008), and the data were collected from sources including company annual reports, media releases, and the social media website Linkedin.

\subsubsection{Phase 2: Director and shareholder focus groups}

Before conducting comprehensive surveys of both directors and shareholders it was intended to conduct focus groups with experienced directors, shareholders and institutional investors. Focus groups are a methodology which has proven to be useful for understanding topics from a specific populations' perspective and are useful for gaining a perspective of issues not generally addressed in the literature (Asbury,1995). Focus groups are therefore suited to this phase of the research which has a developmental objective. The purpose of this phase was to 
tease out the key issues, to ensure that the concepts being examined were relevant, and to identify any other issues or factors that either shareholders or directors considered significant when considering their expectations of boards; and, to ensure that the subsequent research initiatives were positioned appropriately in terms of the topics covered, the language used and the depth to which issues were probed. To overcome the reluctance of many directors to discuss boardroom activity (Leblanc \& Schwartz, 2007), it was decided to approach five very senior directors, all of whom have been chairmen of NZX20-listed companies, and four of whom were approaching retirement. It was assumed that directors at this phase in their careers may be more inclined to discuss these issues than younger, less experienced directors. Contact was made through an intermediary (himself a former chairman of a very large New Zealand company) who vouched for the researcher. A similar approach was adopted in an attempt to conduct a focus group for key executives within institutional shareholders, but it proved unsuccessful as the CEOs were reluctant to be interviewed, either as part of a focus group or individually. A second focus group was conducted with six individual shareholders. In this case contact was made directly with the shareholders, who were identified by the Shareholders' Association based on the following criteria: experience in investing, amount invested, gender, general commercial experience.

Both the focus groups and the interviews followed the same process. Firstly group members were asked for their comments on a series of questions on topics that the literature review suggested may influence their expectations of boards, and then a round table discussion tackled the broader board and shareholder issues. There was no shortage of comment or debate in either focus group and both continued for over three hours. Recordings of the focus groups were transcribed and some basic content analysis was performed to highlight the key themes along the lines described by Cavana, Delahaye \& Sekaran (2001, pp. 171-175). The results of 
this analysis along with the literature review were then used as inputs to Phase 4 of the research, the director and shareholder surveys.

\subsubsection{Phase 3: Annual shareholder meeting minutes analysis}

Annual shareholder meetings (ASMs) are the one instance where directors are legally obliged to meet with shareholders to discuss the affairs of the company (Companies Act 1993, section 120). Minutes of these meetings are taken but they are not circulated to shareholders and the board is not required to ratify them at the following meeting, so for the most part they are unscrutinised by shareholders. There is no obligation for companies to divulge the contents of these minutes to anyone other than shareholders, although, as will be shown, a few companies do publish them on their websites. The contents of these minutes provide a unique perspective on the director-shareholder relationship because they often record questions that shareholders raise regarding the performance of the board, as well as the directors' responses. The minutes also record details of any motions raised and they frequently record the votes cast in favour and against such motions. This provides further information on the degree to which shareholders participate in the governance role and the degree to which they are satisfied with certain aspects of the directors' performance. The author is not aware of any such analysis of ASM minutes being conducted previously in New Zealand.

The methodology adopted for this phase is as follows:

1. Data collection. The company secretaries of all 112 listed companies were approached for copies of ASM minutes from their last three meetings.

2. Validity check. In order to ensure that the sample companies were indicative of the market as a whole, comparisons were made between those companies that provided 
minutes and a reference sample of NZX companies. The size of the largest shareholder, market capitalisation, number of shareholders, and board size of the two samples were compared. These features were selected because they were considered to have the potential to influence the decision to provide copies of their ASM minutes. In each case a t-test was conducted to check for variance between the companies who provided their minutes and a reference sample of companies. The reference sample consisted of either the entire market, when evaluating the board size and market capitalisation, or a selection of 40 companies selected at random for the remainder of this analysis. A threshold of $p<0.05$ was set to determine the significance of any variations.

3. Analysis of questions asked by shareholders. All of the questions asked by shareholders that were recorded in the minutes were collected, manually coded and grouped in line with the content methodology analysis proposed by Cavana et al. (2001). The content analysis methodology is a "systematic replicable technique for comprising many words of text into fewer content categories, based on explicit rules of coding"' (Stemler, 2001). The coding was performed manually because it required a comprehensive understanding of the content of the minutes. The categories selected were derived from the data itself, and include company strategy, reporting, risk and operations. In total the questions were grouped into 12 categories.

4. Analysis of votes cast. The results of all votes cast at the meetings were collated and summarised. They were also analysed according to the nominating party (either the board or a shareholder) to see if there were significant differences in the outcome depending on who proposed the motion. 


\subsubsection{Phase 4: Director and shareholder surveys}

This section of the research consisted of two surveys: one targeting directors and the other shareholders. The director survey was sent to 400 NZX main board directors and the shareholder survey was sent to 1083 individual shareholders, whose names and addresses had been sourced from a public company share registry. Sample sizes were determined by budget and resource constraints. A large share of the director population was sampled because it was assumed that directors would be less likely to respond to the survey. To increase the probability of directors responding, the survey omitted personal questions such as gender, director status (inside or outside), and anything that may identify the company/ies of which they are a director. This led directly to a limitation of the survey: because directors were not asked to reveal the boards they are associated with it was not possible to determine the degree of heterogeneity within individual boards.

The surveys consisted mostly of questions requiring closed responses, and were constructed so that most of the data could be recorded using either nominal or ordinal scales to simplify analysis and to allow for comparisons between the results of the two surveys. There were also opportunities for respondents to add free-form comments. These comments were collated and later used to reinforce the themes identified in the numeric data. The questions were based around the following four areas:

1. Qualifying. These questions ensured respondents were qualified to answer the survey and to provide data for further detailed segment analysis.

2. Roles and responsibilities of the board. These questions evaluated opinions regarding board responsibilities and priorities. This is an area that had previously been explored by Ingley \& Van der Walt (2005) from a director perspective. However, that research was not restricted to public company directors, and it occurred before the global financial crisis and 
the subsequent changes in legislation. Furthermore, it did not examine in detail the tasks that directors are expected to perform. This survey therefore extends and updates Ingley \& Van der Walt's research from a public company perspective by examining shareholders' views as well as directors, and by investigating the role of the public company director in more detail. For example, it considers the role of the director when the company is trading normally and the role of the board when the company is under financial stress.

3. Governance theories. These questions were designed to assess if respondents are more favourably disposed towards agency or stewardship theory or to stakeholder or shareholder theory.

4. Topical issues that may cause friction. These were issues that had been identified as being topical, either through their frequent discussion in the popular press or because they were issues raised by shareholders and directors in the focus group research phase of the project as potential points of difference, either between directors and shareholders, or within these groups themselves. The specific issues examined included the role of women, CEO remuneration, dividend policy, and board-shareholder communication.

Numerous sets of guidelines and checklists exist to assist with questionnaire development; Fowler (2009), Schwartz (1999) and the US General Accounting Office (1993) were used as reference points. A cognitive interviewing approach was adopted for refining and testing the survey. The surveys were first laboratory-tested and then field-tested with a small group of directors and shareholders, with refinements made incrementally as required, in line with the process outlined by Beatty \& Willis (2007). The data analysis was performed in two stages: first the results from each of the director and shareholder surveys were collated and analysed separately; next, a comparison was made between the two groups. Chi-squared tests were performed to test for variations between segments, and in line with traditional governance 
research practices a significance threshold of $p<0.05$ was set (Nuzzo, 2014). Industry-specific data were not collected, because there is no evidence from either the literature review or the preliminary focus groups to suggest that board practices or director and shareholder expectations vary by sector or industry.

\subsection{Ethical Considerations}

The research did not present any significant ethical challenges. Approval for the research was sought and received from Victoria University of Wellington's Ethics Committee and the research fully conformed to its guidelines. The research also conformed to Tolich \& Davidson's five key ethical principles (2011, pp. 155-157). The focus group participants were fully briefed, and all signed consent forms. No issues were raised subsequent to the research. The identities of the individuals and the companies discussed remain confidential. The postal surveys were anonymous and the responses cannot be linked to the individuals who were sent the survey. All of the other research was based on publicly available data and therefore raised no ethical issues.

Because confidentiality was very important, issues such as who has access to the data, where it is stored, and how and when it is disposed of were of paramount importance. The UK Data Archives policies on data management have been adopted in this regard (van den Eynden et al., 2011).

\subsection{Positioning the Researcher}

A relativist ontology has been adopted for this research which acknowledges that the background of the researcher has the potential to influence what has been observed (O'Leary, 
2010) and this has been considered in the design of the methodology. Specifically my background as the managing director of an NZX-listed company has been taken into consideration and has influenced both the design of the research methodology and its implementation. Potentially this background has advantages when interacting with other directors and with company representatives such as company secretaries, as I am viewed as an insider, and this may have allowed access to individuals and data that would not normally be accessible to researchers. Unfortunately this background also has disadvantages, particularly in interactions with shareholders and other stakeholder groups. For example, during preliminary discussions with representatives from some lobby groups it became apparent that I was being treated as a director who needed to be 'sold' to rather than as a researcher. I therefore concluded that I could not conduct effective interviews with these groups and so this element was not included in the final research methodology. The focus groups were the formal, face-toface component of the research and they were used sparingly to assess the breadth and variety of views rather than to form the primary component of the research. When conducting these focus groups particular care was taken to reduce the possibility of researcher bias - for example, the sessions were conducted on neutral ground, and effort was made to ensure that the research conformed to the guidelines outlined by O'Leary (2010), such as ensuring the researcher acted as a facilitator and moderator and not a participant. Throughout the research the results of individual research elements were triangulated and cross-referenced with other elements to identify common themes and highlight potential anomalies in the results that could have arisen due to researcher influence, such as discussion at focus groups that emphasised the researcher's own company and circumstances. 


\subsection{Summary}

The principal question that this research is intended to answer is: 'What do New Zealand's shareholders and company directors expect from New Zealand public company boards?' To address this question, the research considered three elements - directors, shareholders, and the environment in which they operate - and conducted a series of individual research initiatives, each of which focused on some aspect of these elements. The results of these individual research initiatives were then compared and contrasted to obtain an overall answer.

The research itself comprised four individual phases. Phase 1 was designed to update some demographic data such as board gender diversity, foreign ownership and director tenure. It also fills in gaps not previously researched such as the contribution of director human capital to boards. This provides a comprehensive foundation for the subsequent phases of the research. Phase 2 involved conducting two focus groups, one with experienced directors and the other with experienced shareholders. These focus groups were intended to ensure that the subsequent phases of the research addressed relevant issues. Phase 3 involved analysing the minutes from company ASMs. This provides a unique perspective on the interaction of the two stakeholder groups. Finally, Phase 4 involved conducting written surveys to obtain the views of shareholders and directors directly.

The research has been approached from a post-positive perspective, with particular attention being paid to the researcher's background, and care was taken to ensure that every aspect of the research complied with VUW Ethics Committee research guidelines.

The main limitation of the research was the inability to obtain primary data from institutional investors. As will be shown in Chapter 4, institutional investors play a significant role in the New Zealand market and their reluctance to participate directly in this research has limited its overall scope. This has been partially mitigated by obtaining data from secondary 
sources. Resource limitations also influenced the scope of the research, specifically restricting to 40 the number of companies whose ownership and shareholdings were analysed, and limiting the size of the postal shareholder surveys. The samples are, however, of sufficient size to allow statistically sound inferences to be drawn from the data. Overall the research methodology adopted is comprehensive and in drawing on data from multiple independent sources is robust enough to minimise any impact of these limitations. The following chapters outline the results of this research and provide an answer to the question, "what do directors and shareholders expect from NZ public company boards?" 


\section{THE NZ CORPORATE GOVERNANCE ENVIRONMENT}

It has long been recognised that certain structural aspects of a country's commercial environment strongly influence corporate governance practices (Shleifer \& Vishny, 1996; Aguilera \& Jackson, 2003). Therefore it is important to gain an understanding of the New Zealand environment in order to appreciate how it can influence shareholders' and directors' expectations of boards. In recent years the $\mathrm{NZ}$ commercial environment has gone through a period of significant change, most notably the impact of the 2007-8 global financial crisis on company performance. This has led to a hardening of the courts' attitude towards recalcitrant directors, the introduction of the Financial Markets Authority, and an influx of new listings to the NZSX. As a result of these changes, some of the literature on the structure of the NZ public company market is now outdated.

This chapter examines the New Zealand corporate governance environment in order to identify features that have the potential to shape or influence shareholders' and directors' expectations of New Zealand boards. Five specific elements are examined beginning with the legal environment which is addressed by reviewing the current literature. The equities market, the companies listed on the NZSX, and the characteristics of shareholders and of directors are all then reviewed. The literature on each of these elements is reviewed and, as will be shown, was found to be incomplete or outdated. To address this issue, wherever possible, the existing research was updated with more recent data; this ensures that any effects of the recent changes in the environment are captured, and it also allows longer-term trends to be identified. This updating has been necessary when considering aspects of the environment such as: company market capitalisations, board size, the share of executive, independent and female directors, and director tenure. The literature review also highlighted some areas of relevance to directors' and shareholders' expectations of boards where research had either not previously been conducted or was incomplete. In these cases new research was conducted, to include research into the 
distribution of shareholdings, the control of public companies, the linkages between company directors, and an analysis of the intellectual capital that directors contribute to boards. The chapter concludes by summarising the overall NZ corporate governance environment and highlighting the key trends and factors which are likely to influence both directors and shareholders expectations of boards.

\subsection{NZ Company Law}

Until 1993 all New Zealand company law was derived directly from UK company law and is therefore firmly based on the Anglo-Saxon corporate governance model (Cernat, 2014). The British acts were simply incorporated with a few minor changes to reflect New Zealand's status, first as a colony and later as a dominion. In 1993 New Zealand adopted its first truly 'home grown' Act. The Act was introduced in the aftermath of the 1987 stock market crash, an event that had a considerable impact on the psyche and financial well-being of many New Zealanders. In July 1987 , over $40 \%$ of the country's adult population owned shares and by 18 September the market had risen $600 \%$ since 1982 to an all-time high. Then on 20 October, a drop in the US equity markets triggered a collapse that resulted in a drop of over $40 \%$ in the value of the equities market over the following 10 months. Of the 309 companies listed on the NZX in 1987 only 140 remained by 1993 (Grant, 1997). This was the most significant event to date for the New Zealand Share Market; it quite probably influenced the legislators drafting the Act, and it may be the reason that the 1993 NZ Companies Act arguably sets higher standards for director behaviour than either the US (Delaware) or UK acts of the time.

From a director perspective, the 1993 Act sets some clear guidelines for director responsibilities and behaviour. Section 128 states that: 'The business and affairs of the company must be managed by, or under direct supervision of the board of the company' 
(Companies Act, 1993, p. 113). By including this section in the Act, the legislators have quite clearly established that responsibility for the company and its actions sits squarely with the directors and the board. The Act also provides some boundaries for board and director behaviour; it states, for instance, that 'to act in good faith and in the best interests of the company and when exercising their powers, directors must exercise the care and diligence and skill that a reasonable director would exercise in similar circumstances' (ibid., p. 121). This is essentially defining a statutory safe harbour for directors and boards. Provided that directors adhere to these guidelines they will not be personally liable to the company or to the shareholders. This is a substantial raising of the bar, in terms of the behaviour that is required in order for a director to avoid personal liability, as it replaces the previous moral standard for director liability with an objective standard. Some argue that this move to an objective standard makes New Zealand companies more risk averse, a trait that they see as undesirable (Gillman \& Hogan, 1999).

'To act in good faith and in the best interests of the company' is a significant philosophical shift for boards that requires further discussion, given that it arguably moves New Zealand from a shareholder-centric model of governance to a stakeholder-centric model. Although previous versions of the Act were silent on the question of who the board is responsible to, it is reasonable to conclude that prior to this Act directors assumed they were responsible to the shareholders. This is because the shareholders appoint directors, and it is the shareholders who had typically been considered for all practical intents and purposes the company's owners. In effect the 1993 Act decrees that, although shareholders have certain rights, ultimately they are simply another stakeholder group and as such should not be afforded any special consideration. The directors must ensure that the company's interests are the priority. The Act therefore creates an environment where directors are appointed by shareholders but are responsible to the company. Situations can, and do, arise that place 
directors in conflict with shareholders. For example, in the situation where a company holds a large cash reserve, directors may choose to retain the cash while shareholders may prefer that it be returned to them. The conflict occurs because the shareholders, on whom the directors must rely for their appointment, have a short-term objective (cash in the pocket), which may be different to the longer-term objectives of the company.

The Act also acknowledges the complexity of modern business in that it allows directors to rely on reports and the advice of experts. This was recently tested in a dispute between shareholders and directors of the former carpet maker Feltex. Some 800 shareholders joined together in a class action against the directors (Stewart, 2012); subsequently a case was taken by the Ministry of Economic Development against five of the former Feltex directors. The case hinged on whether it was reasonable for Feltex directors to rely on expert advice from an external accounting firm even though one of the directors was a former chair of New Zealand's accounting standards body. The court felt that it was reasonable for the directors to rely on the advice they received, and they were acquitted. This case also highlights an example of directors and shareholders having different expectations of the role of the board (MohdSulaiman, 2013).

Like British and US law, New Zealand law leaves the task of setting most of the rules of the company to the directors and shareholders. In New Zealand, these rules are recorded in the company's constitution. The NZX listing rules provide some constraints on what can be included in company constitutions; for example, so-called poison pill or anti-takeover clauses cannot be included (NZX, 2013).

The regulatory environment governing the issuing of securities to the public has changed substantially in recent years. The Securities Act 1978, which is the underlying law in this area, underwent a substantial revision in 2009 (Securities Regulations, 2009). The new Act 
increased the penalties for behaviours such as making false or misleading statements or false trading. These actions are now criminal offences punishable by fines up to $\$ 1 \mathrm{M}$ or five years' imprisonment. In addition to firmer regulations, the Financial Markets Authority (FMA) was established to enforce them. The FMA's main objective is to promote and facilitate the development of fair, efficient and transparent financial markets (FMA, 2014), and its establishment marked a major shift in the way securities law is implemented in New Zealand. Prior to the FMA era the issuing of securities, such as shares in public companies and bonds, was overseen by the Securities Commission. The Securities Commission oversaw an enforcement regime that relied largely on private enforcement, and because the Commission did not have the power to enforce securities law directly in a timely and effective way, NZ was considered by international standards to provide a low level of protection for investors (La Porta et al, 2006). With the introduction of the FMA enforcement has now moved from a private to a public regime, with the FMA actively prosecuting directors and others for alleged breaches of securities law. However, civil remedies also remain available (Securities Regulations, 2009). The impact of this new environment on director and shareholder behaviour has yet to be researched, and there is moreover a view that the regulatory environment still requires fine tuning, so it may be some time before the ultimate impact of these regulations on shareholders' and directors' expectations of boards can be determined (Maume \& Walker, 2013).

The NZX has adopted a continuous disclosure regime which obligates companies to disclose anything that could potentially influence a company's share price as soon as the company is aware it (NZX, 2013, section 10). The objective of this policy is to eliminate insider trading by ensuring that all shareholders have access to share price and other potentially share price-sensitive information at the same time. 


\subsection{The Equities Market}

The size and importance of the equities market relative to the overall economy likely influences the general public's and legislators' attitudes towards public companies and their governance. This section briefly discusses the place of the equities market within the overall New Zealand economic environment.

The New Zealand stock exchange consists of two boards: a main board, the NZSX, and a secondary board, the NZAX. The NZSX has 112 companies listed and there are a further 19 on the NZAX board. This is similar in scale to the Belgian stock exchange, which has 131 companies listed, but is dwarfed by the Australian market with 2153 companies and London with 2455. In September 2013 the market capitalisation of NZX-listed companies was $\$ 81.6 B$, or approximately 37.5\% of GDP (NZX, September 2013; Reserve Bank, September 2013). As Figure 2 shows, the New Zealand share market plays a relatively small part in the economy when compared to some other advanced economies. Recently the contribution of the NZ stock market has grown from a low of $31 \%$ of GDP in 2011 to $37.5 \%$ of GDP, largely as a result of the listing of a number of SOEs on the NZSX and a surge in NZ equity prices. However, the longer-term trend suggests that the gap between the contribution of the New Zealand share market to the economy relative to other advanced countries is widening. In 1996 the NZ market was $56 \%$ of GDP and the Australian market $68 \%$; some market analysts expect that in the longer term Australia's stock market will continued to grow in importance while New Zealand's will decline (Doyle \& Cheong, 2011). 


\section{Figure 2}

Market capitalisation as a percentage of GDP 2011

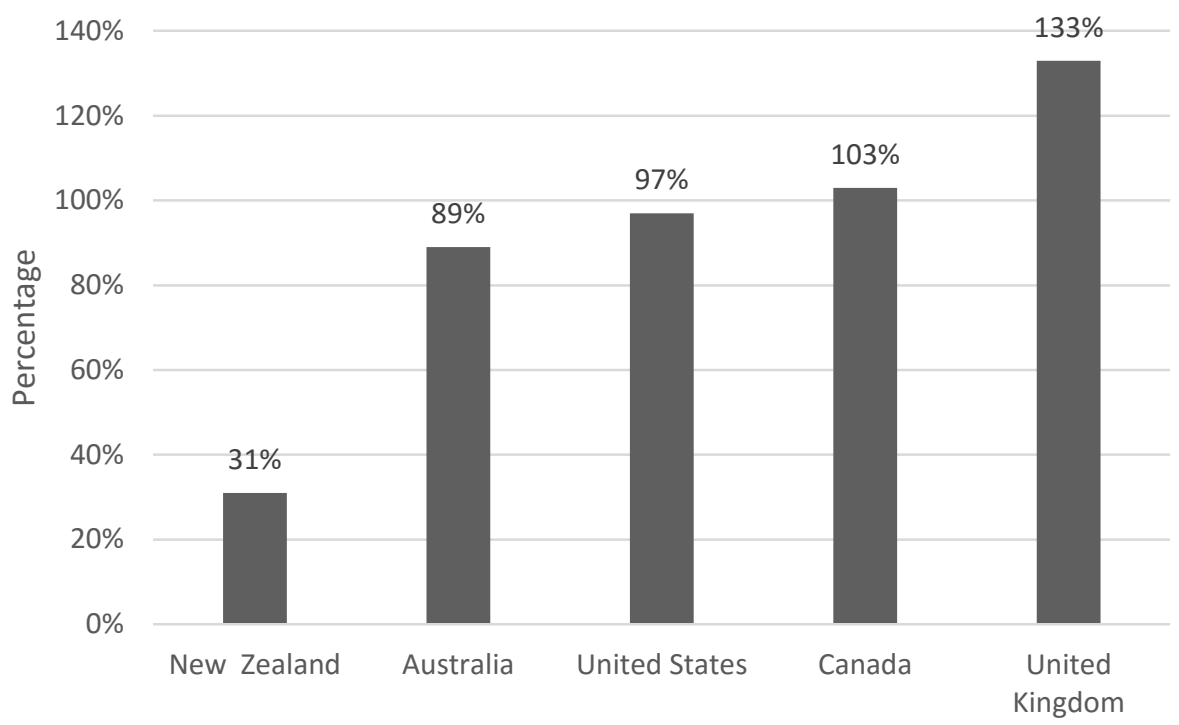

Source: Doyle \& Cheong (2011).

Another reference point for the relative unimportance of the NZX is the residential housing market; residential housing is a popular investment for New Zealanders and likely competes with NZX equities for New Zealanders' investment dollars. The retail value of all residential homes in New Zealand is estimated at $\$ 689 \mathrm{~B}$, over eight times the combined market capitalisation of all NZX equities (Reserve Bank, September 2013). This suggests that, for most New Zealanders, investment in local equities is not a major contributor to their total net worth, and this is a factor that may influence their attitude towards NZX-listed companies and their boards.

\subsection{NZ Public Companies}

This section examines the companies listed on the NZSX market. Berle and Means (1932) first identified that the size of companies, the distribution of their ownership, and who controls them 
are all factors that influence board behaviour, so these aspects of NZ public companies are now discussed. The size of company boards (Forbes \& Milliken, 1999) and the sharing of directors between companies (Johnson et al., 2012) have also been shown to potentially influence board behaviour and hence director and shareholder expectations of boards, so these features of NZ companies are also discussed.

\subsubsection{Company size}

Table 8 summarises the market capitalisation of companies listed on the NZX main board as at December 2013.

\section{Table 8}

Market capitalisation of NZSX-listed companies

\begin{tabular}{lrrrrr}
\multicolumn{7}{c}{ Market capitalisation (\$M) } \\
Size & $<100$ & $100-500$ & 1000 & 2000 & $>2000$ \\
& 41 & 34 & 13 & 13 & 10 \\
\hline Number of companies & 37 & 31 & 12 & 12 & 9
\end{tabular}

The mean market capitalisation is $\$ 680 \mathrm{M}$ and the median market capitalisation is approximately $\$ 229 \mathrm{M}$. This table shows that the NZX is dominated by a large number of relatively small businesses. Smaller companies have fewer resources to dedicate to investorrelated activities and this may well influence both director and shareholder expectations of boards. 
Table 9 shows the trend in the mean market capitalisation of companies from 1995 to 2013, expressed in 2013 dollars. ${ }^{3}$

\section{Table 9}

Mean market capitalisation of NZSX-listed companies

Company market capitalisation (2013 \$M)

\begin{tabular}{lrrr} 
Year & 1995 & 2010 & 2013 \\
\hline Mean & 696 & 611 & 680 \\
Median & 102 & 123 & 229 \\
Sample size & 86 & 117 & 112
\end{tabular}

Source: 1995 and 2010 data from Boyle \& Ji (2011) 2013 data from NZX December 2013.

As Table 9 shows, the market has remained relatively static since 1995 . However, the median market capitalisation has jumped substantially in 2013, possibly as a result of a number of large state-owned enterprises (SOEs) listing on the stock market and a meteoric rise in market capitalisation of some IT companies. Overall, however, the picture is of a market that is essentially static, which reinforces the view that NZ company owners and investors are somewhat ambivalent toward the NZX. A consequence of having small companies listed in the exchange with low liquidity is that it is not economically attractive for brokering groups to research these companies. ${ }^{4}$ As will be shown in section 7.2, many investors are reluctant to invest in firms without the benefit of research, and this further reduces their liquidity.

\footnotetext{
${ }^{3}$ Adjusted using the Reserve Bank's Inflation Calculator http://www.rbnz.govt.nz/monetary_policy/inflation_calculator/.
}

\footnotetext{
${ }^{4}$ Forsyth Barr, one of New Zealand's largest retail share broking firms, conducts research on just 68 of the 112 listed companies (Forsyth Barr, 2015).
} 


\subsubsection{Ownership distribution}

One of the key issues defining and shaping the overall governance process and the relationship between shareholders and directors is the degree to which ownership is dispersed and control is centralised. The issue was first addressed in a US context by Berle and Means (1932) and it is their assumptions around these parameters that have underpinned much of the theory and literature on governance ever since. More recently, research has been conducted into the distribution of ownership of NZ companies.

In order to develop an indication of how widely distributed ownership is among NZSXlisted companies a random sample of 40 companies was taken and the statutory shareholding information that is disclosed in their 2013 annual reports was analysed. Table 10 summarises the results.

\section{Table 10}

Distribution of shareholdings in NZSX-listed companies

\section{Shareholding distribution}

\begin{tabular}{lrrrrr} 
& & & $5001-$ & $10,001-$ & \\
Size of holding & $1-1000$ & $1001-5000$ & 10,000 & 100,000 & $100,000+$ \\
\hline Proportion of shareholders (\%) & 27.6 & 40.2 & 13.9 & 17.0 & 1.3 \\
Proportion of shares held (\%) & 0.9 & 4.4 & 4.3 & 13.4 & 77.0 \\
Average number of shareholders & 3028 & 4411 & 1521 & 1870 & 141
\end{tabular}

Sample size: 40 companies.

\footnotetext{
${ }^{5}$ The divisions selected match those used by companies in their annual reports.
} 
Of the 40 companies sampled, the total number of shareholders in each company ranged from 846 to 49,646 with an average shareholding of 10,971 and a median of 6152 . The small median once again highlights that a large number of small companies is listed on the NZSX.

Furthermore, in 38 of the 40 companies surveyed at least $50 \%$ of the shares were held by $2 \%$ of the shareholders. Conversely $77 \%$ of shareholders own just $9.5 \%$ of the shares. This highlights the relatively significant power of a few individual shareholders and is likely to influence director behaviour and attitudes towards shareholders.

\subsubsection{Control of New Zealand companies}

From a governance perspective the answer to the question 'What level of shareholding constitutes control?' does not have a single numerical answer. To have total control over all aspects of a NZ company requires a 75\% super majority (Companies Act, 1993). However, from a practical perspective it is generally agreed that a $20 \%$ shareholding is sufficient for effective control of a publicly listed company, and in certain circumstances $10 \%$ may be sufficient (La Porta et al., 1999). Investment bankers Goldman Sachs consider shareholdings of $10-20 \%$ to be 'strategic' shareholdings that are significant enough to influence the direction of a company (Maume \& Walker, 2012).

To determine the level of control shareholders can exert over New Zealand companies, again the same sample of 40 companies has been analysed using the cut-off points of $10 \%$ and $20 \%$ as references. The analysis looks back one level of ownership - so, for example, where a block of shares is owned by a company, the ownership of this and any subsequent companies in the chain has not been traced to determine the ultimate ownership of the share parcel. Although attempts at such analysis have been made in the past (La Porta et al., 1999; Cameron, 2007), such analysis is of limited value for two reasons: firstly it cannot account for any agreements and undertakings between shareholders to block vote their individual shareholdings, and 
secondly there are situations where a strategic or controlling shareholder such as an institution or government entity may, as a matter of policy or simple expediency, choose to not actively participate in the governance of the company in which it holds shares unless an extraordinary event occurs (Tan \& Keeper, 2008; Ingley \& Van der Walt, 2004). So in practice it is impossible to precisely quantify the level of control shareholders have over boards or the situations where they would choose to exercise this control.

Using the same sample of 40 companies, the statutory shareholding information that is disclosed in their 2013 annual reports was analysed to identify the largest shareholder. Figure 3 shows the percentage of the company's shares that the largest shareholder holds and the nature of the shareholder (i.e. private investor, institutional investor or public entity). Public entities are government-owned bodies. 


\section{Figure 3}

Size of largest shareholder's stake 2013

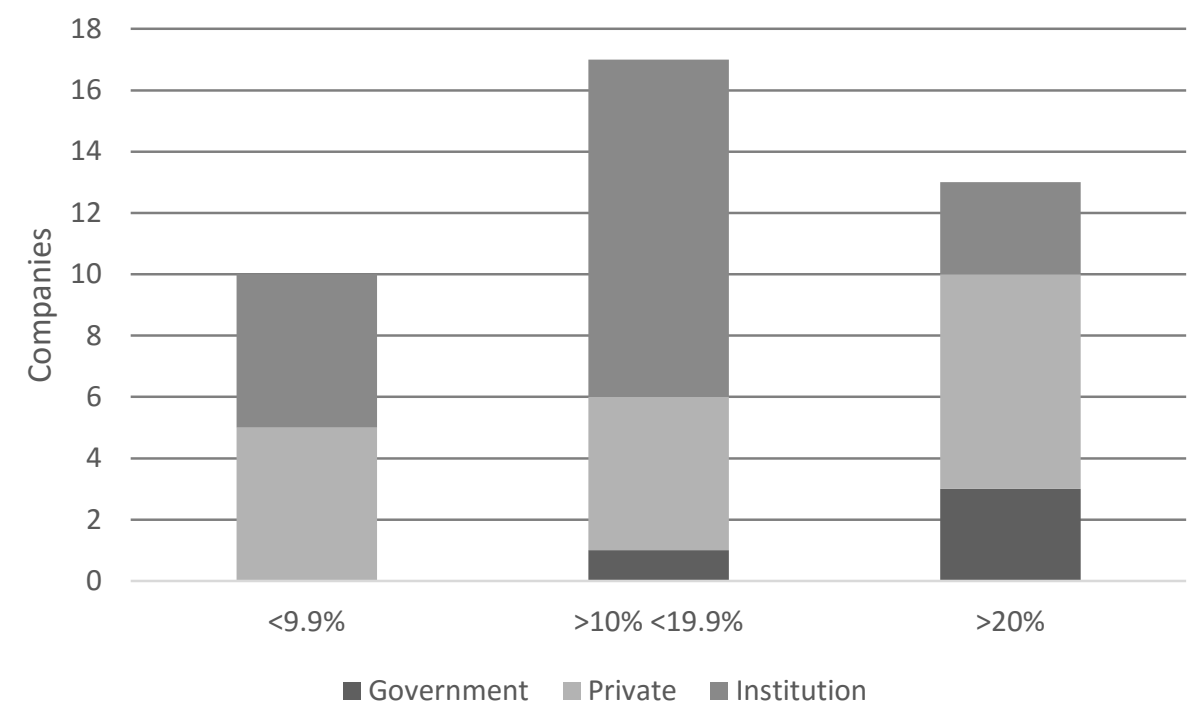

The chart highlights the importance of institutions in the governance process. Not only are institutions the largest or even the controlling shareholder in a substantial number of companies (19 of 40), but their position towards the head of so many share registers places them in a strong position to shape the broader governance agenda in New Zealand. How they choose to exercise this influence is discussed later in this chapter. In 27 of the 40 companies sampled the largest shareholder has a shareholding of less than $20 \%$ of the total shares on offer, which suggests that in a significant number of New Zealand's public companies no individual shareholder has practical control of the enterprise. This is the situation that so concerned Adam Smith (1776) and which has underpinned much of the thinking on governance practices from Berle and Means (1932) to Jensen and Meckling (1976), and through to the present day. This is significant from the perspective of both shareholders' and directors' expectations of boards, as there is some evidence to suggest that NZ companies with large block shareholders outperform those with more dispersed shareholdings (Boone, Colombage \& Gunasekarage, 2011; Bhabra, 
2007). Also, as will be shown in section 4.4.4, large block shareholders have more ability and incentive to monitor the performance of both the company and its governance structures and to take action when performance is unsatisfactory, suggesting that the size of shareholding may influence shareholders' expectations of boards.

From a director perspective the lack of a controlling shareholder clearly removes a substantial constraint on behaviour. The threat of being taken over by another company (commonly referred to the market for corporate control) is considered a strong external control mechanism on management and boards alike (Jensen, 1983). Quite simply, the threat of being seen as the steward of underperforming assets and ultimately losing one's job is seen as a strong incentive to perform. However, NZX-listed companies are seldom the targets of takeover bids either friendly or hostile (although 2013 was an exception, with two friendly takeovers occurring and one unsuccessful hostile takeover attempt). There are a number of factors that make takeovers in general (and hostile takeovers in particular) more difficult in the New Zealand environment. These include the impact of the 1993 Takeovers Act and the practice of staggered board appointments (Marshall \& Anderson, 2009; Adams et al., 2010). It therefore appears unlikely that the threat of takeover is a significant constraint on the behaviour of New Zealand boards.

\subsubsection{Board size}

The size of a company's board is a topic that has been researched regularly in the governance literature both internationally and in New Zealand (Reedy et al., 2010; Koerniadi, et al., 2013), perhaps because it is such an easy metric to collect. The relationship between board size and company performance has been well documented and is shown to be tenuous at best (Reedy et al., 2010). Koerniadi et al. (2013) claim that larger New Zealand boards are more risk averse than smaller boards. This assertion is based on the assumption that the variations in share 
returns are a proxy for board propensity for risk taking. Although Koerniadi et al. suggest some possible reasons for this they do not assert that there is a causal relationship between board size and propensity for risk taking. However, their research, and much of the other research in this area, uses the traditional 'black box' methodology discussed in section 3.2 and therefore is subject to the criticism raised by Gabrielsson \& Huse (2003).

The average size of New Zealand public company boards has been reasonably static since at least 1995, as Table 11 shows.

\section{Table 11}

Trend in board size of NZSX-listed companies

\begin{tabular}{lrrr} 
& Board size \\
& 1995 & 2010 & 2013 \\
\hline Mean & 6.6 & 5.9 & 6 \\
Median & 6 & 6 & 6 \\
Sample size & 86 & 117 & 112
\end{tabular}

Source: 1995 and 2010 data from Boyle \& Ji (2011), 2013 data from NZX company websites Dec 2013.

The number of directors on NZSX-listed companies ranges from three to 12. Figure 4 summarises the distribution in December 2013. 


\section{Figure 4}

Board size of NZSX-listed companies

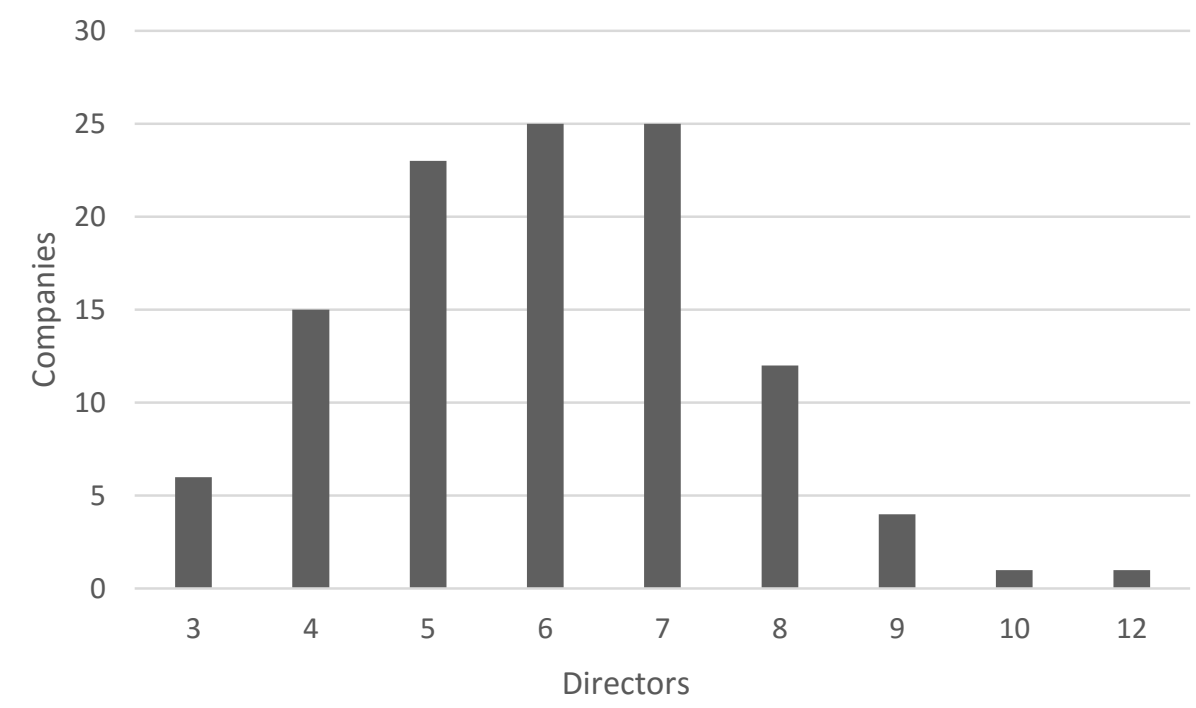

Source: Derived from the Companies Office director database (Companies Office, 2013).

There is a correlation $(\mathrm{r}=0.398)$ between the size of a company as measured by market capitalisation and the number of directors, suggesting that companies with a larger market capitalisation tend to have larger boards. This is consistent with findings from other jurisdictions (Yermack, 1996; Boone et al., 2007).

\subsubsection{Shared directors}

Some directors sit on the boards of several NZSX companies. A company director who serves on the board of two NZSX companies creates a link between the two companies. Figure 5 shows the frequency of such links between NZSX companies. 


\section{Figure 5}

Links between NZSX company boards

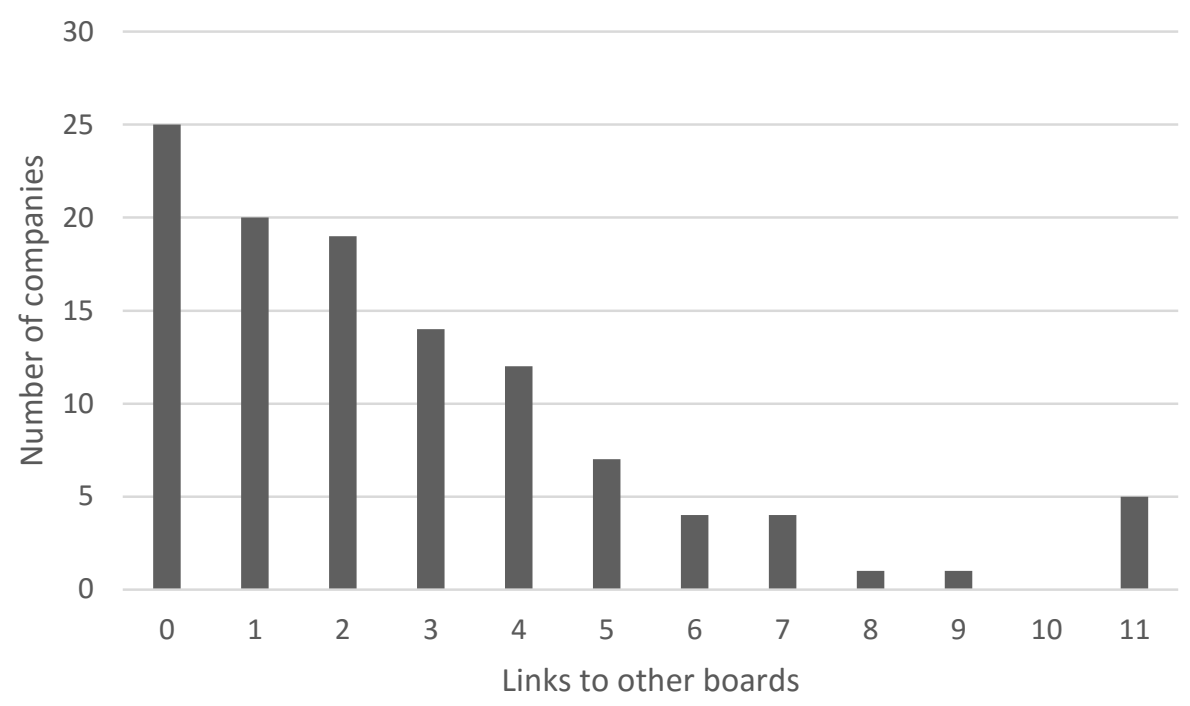

Figure 5 shows that 87 of the 112 NZSX companies (78\%) have such links to one or more other public companies. Directors who sit on multiple NZSX boards can act as a conduit to provide more, newer, and potentially more valuable information from outside the company. Because NZX directors are not obliged to be members of the Institute of Directors or to attend any formal training or seminars, this passing of ideas between boards may play a significant role in influencing the behaviour and expectations of all NZX directors; it may also create some homogeneity between directors.

As will be shown in section 6.1, directors frequently recruit many of their fellow directors. By examining these director links between boards it is possible to gain some insights into the attributes that directors value in their peers. Figure 6 maps all of the director links between NZSX companies as at December 2013. The squares represent individual companies and are identified by their ticker symbol; the lines between the companies represent the director links between the companies. Unlinked companies appear at the left-hand margin of the figure. 


\section{Figure 6}

Map of board linkages between NZSX companies

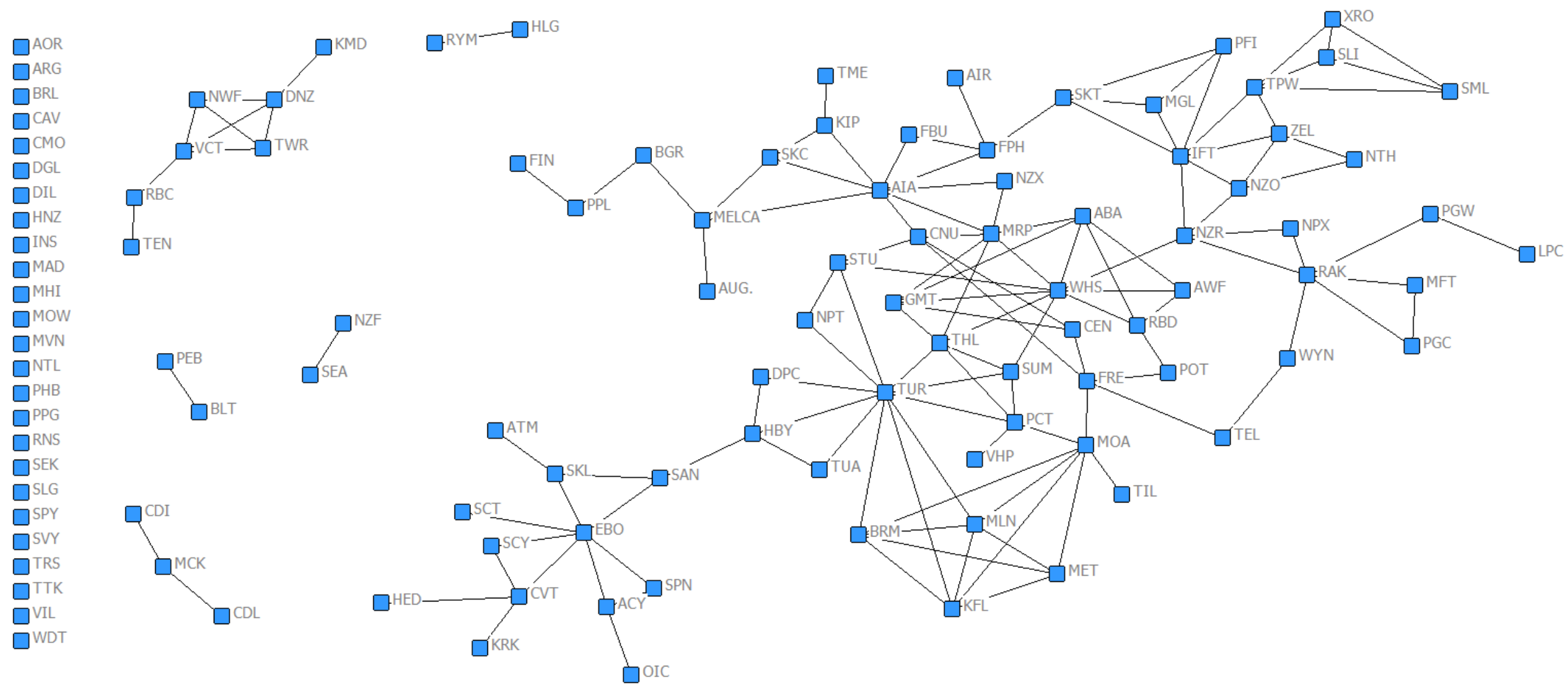

Note: codes are NZSX ticker abbreviations for company names. 
An analysis of these links shows the following:

- Links are seldom between complementary businesses. For example, there are few manufacturer-distributor linkages. This suggests that the prime reason for the links is not to build financial or trading relationship between companies. This is in contrast to the German governance model, where financiers are frequently represented on company boards (Larcker \& Tayan, 2011, p. 45).

- Links are seldom within the same industry. A large number of links between companies in the same industry would suggest that boards valued directors with unique industryspecific knowledge. Because few such links exist, there is unlikely to be a shortage of directors with an appropriate level of industry-specific knowledge.

- Shared directors maybe enhance the human and social capital of boards. The human capital of a board can be enhanced by shared directors' expertise in governance and their ability to share ideas from other boards (Kor \& Sundaramurthy, 2008). Social capital may likewise be enhanced as shared directors can be seen as a source of prestige for companies (Kim \& Cannella, 2008).

\subsection{New Zealand Shareholders}

This section provides an overview of investors in the New Zealand share market. To assist with the analysis the investors have been segmented into four groups, each with unique characteristics that, as will be shown, can influence their relationship with boards and directors. The groups are private investors, institutional investors, foreign investors and public investors. A second segmentation is also conducted which examines block shareholders. Block shareholders comprise any shareholder that holds $5 \%$ or more of the shares in any NZSX company. 


\subsubsection{New Zealand private investors}

The author is not aware of any research that directly addresses the role and behaviour of private investors in New Zealand. 'Private investor' is another of those governance terms that are in such common use that they are seldom defined. Farrar (2008, p. 179) defines such investors simply as 'individuals'. In the context of this research, private investors are considered to be any individuals who have chosen to invest either personally or via a trust or a company structure, but not as a part of a managed fund or superannuation fund, directly in instruments listed on the NZSX.

The New Zealand public, from whom private investors are drawn, have a range of investment options. Table 12 shows an estimate of the average NZ household's assets and the distribution of these assets among major investment categories. This table should be viewed as an estimate only, as making an accurate assessment of these assets is problematic (Briggs, 2012).

\section{Table 12}

New Zealand household assets

Average NZ Household Assets

\begin{tabular}{lrr} 
& Value (\$) & Share (\%) \\
\hline Property & 452,535 & 79 \\
Kiwi Saver/superannuation & 52,000 & 9 \\
Term deposit/term investment & 40,000 & 7 \\
Shares & 16,000 & 3 \\
Unit trust/managed fund & 9,000 & 2 \\
Total & 569,535 & 100
\end{tabular}

Sources: Quotable Value (2014); Colmar Brunton (2013). 
The table shows that New Zealanders choose to invest the vast majority of their funds in property.

Direct investment in the equities accounted for just 3\% of total household assets.

Table 13 shows an estimate of the proportion of NZ adults aged 18 or over who invest in NZX-listed equities.

\section{Table 13}

Trend in share of adult New Zealanders owning NZ equities

Share of NZ adult population owning NZ equities

\begin{tabular}{lrrr} 
& 2005 & 2009 & 2013 \\
\hline Shares (\%) & 21 & 22 & 16 \\
Bonds (\%) & - & - & 13 \\
Unit trust/managed fund (\%) & 15 & 11 & 9 \\
Sample size & 856 & 850 & 852
\end{tabular}

Source: Colmar Brunton (2013).

Combining date from tables 12 and 13 suggests that the average New Zealander who invests in the share market has a portfolio valued at approximately $\$ 100,000 .{ }^{6}$ As Table 13 shows, the number of private investors who directly participate in the stock market is declining. Colmar Brunton (2013) attributes the decline in share ownership between 2009 and 2013 to a change in the wording of the survey question that they asked in their 2013 survey of investors. However, it should also be noted that a similar decline has been observed in Australia, where direct share ownership has dropped from 39\% in 2010 to 34\% in 2012 (ASX, 2012). When viewed collectively, tables 12 and 13 show

\footnotetext{
${ }^{6}$ The average investment in shares is $\$ 16,000$ (Table 12, p.112), and $16 \%$ of the population hold shares (Table 13, p. 113 ), so the average shareholding is $\$ 16,000 / 0.16=\$ 100,000$.
} 
that direct investment in shares is not a principal repository of wealth for the vast majority of New Zealanders and that it may be becoming still less important. This suggests that there is little financial incentive for most New Zealanders to actively participate in any corporate governance activity.

Figure 7 shows that NZ private investors have consistently favoured direct investment over indirect investment by a ratio of $2: 1$. The graph also gives an indication of elasticity of investment in the NZ share market, as well as investors' willingness to exit the market when the economy turns down and re-enter when it turns up (2008 and 2009 were years when equity prices slumped).

\section{Figure 7}

Private investment in New Zealand equities

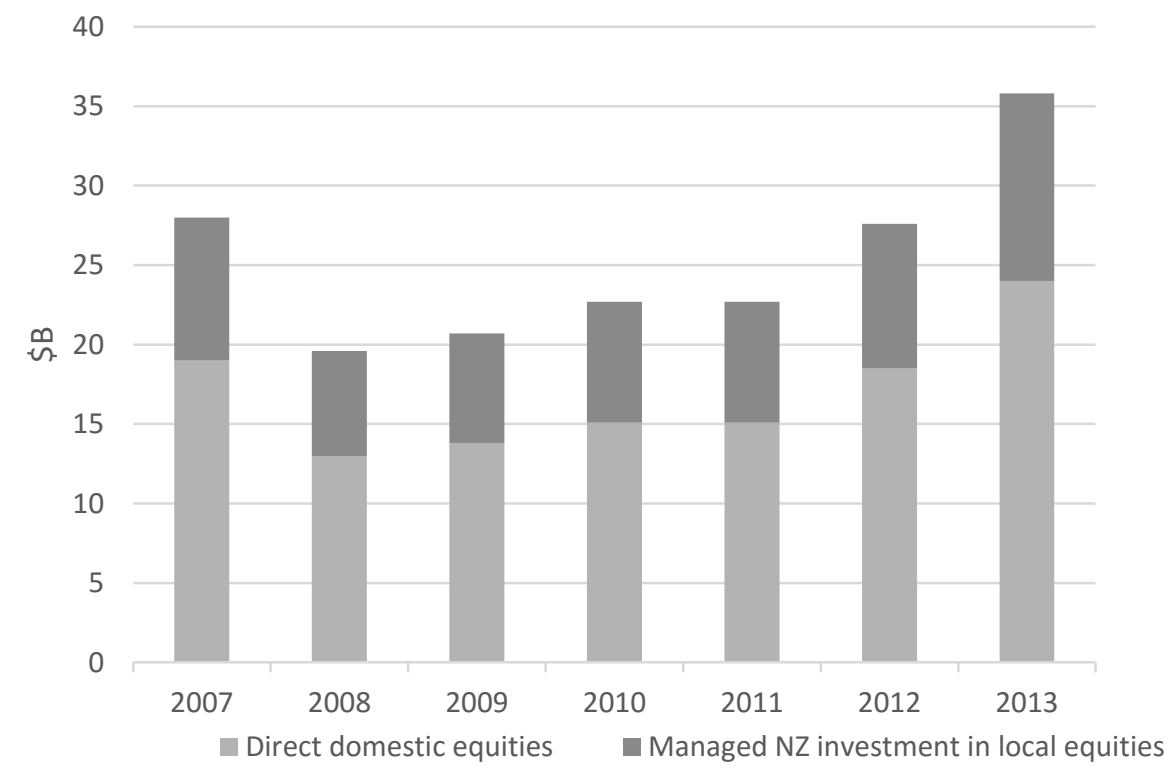

Source: Reserve Bank (2014).

Very little has been published on the profile of New Zealand private investors. Statistics published by the Financial Literacy and Retirement Commission show that share owners are most likely to have high finance knowledge and share many of the following attributes: they own their own home 
in a trust, have personal income of greater than $\$ 100,000$, have a net worth of more than $\$ 600,000$, are tertiary educated, are over 45 years old, and are twice as likely to be male than female (Colmar Brunton, 2013). These are broadly similar characteristics to Australian private investors. In Australia share ownership is most common among the tertiary-educated higher income households, with share ownership peaking among males in the 65-74 age bracket (ASX, 2011).

The ASX (2011) has analysed the behaviour of Australian private investors and has segmented them into four roughly equal categories based on their behaviour. While caution should be taken in extrapolating the Australian experience to New Zealand, the ASX research nonetheless provides a useful framework for considering private investor behaviour. The four categories are:

- Self-reliant dabblers ( $22 \%$ of current direct shareholding owners). Those within this segment have limited knowledge of the share market, and while they are keen to find out more, they note that shares would never be a major part of their investment portfolio. They believe that share market success is more about luck in timing and enjoy managing their investments.

- Informed diligents ( $22 \%$ of current direct shareholding owners). These investors are knowledgeable and reasonably skilled in the share market. They enjoy managing their investments, but they also rely on expert advice to shape their decisions and are highly disciplined. They share a level of excitement about the share market challenge.

- Confident traders (25\% of current direct shareholding owners). Like the informed diligents, those within this segment are the most knowledgeable, skilled and confident investors, tending to buy/sell shares independently. They enjoy managing their investments and are the segment most excited about the share market challenge. Confident traders are fairly disciplined and are mostly self-directed, relying on their own gut feel. 
- Unsure delegators (31\% of current direct shareholding owners). Categorised by their lack of knowledge of the share market, unsure delegators rely on the advice of experts for investment decisions. Of all the segments, they are the ones most likely to find the share market confusing and do not find the share market an exciting challenge. This is now the largest of the current direct private investor segments.

This segmentation suggests that a significant proportion of private investors may lack the confidence or motivation to participate in the governance process. It also suggests that there is a group of shareholders who simply trade shares and who are unlikely under normal circumstances to have any interest in actively engaging in the governance processes of the companies in which they hold shares.

\subsubsection{Institutional investors}

The term 'institutional investor' is largely undefined in the New Zealand context. Farrar (2008), who approaches governance primarily from a legal perspective, defines it as a broad term that 'encompasses pension and superannuation funds, investment companies, mutual funds and unit trusts, insurance companies, banks and charitable foundations. It also includes funds managers who are professionals managing investments on behalf of other institutional investors.' (Farrar, 2008, p. 179.) Although banks and charitable foundations do from time to time perform functions more commonly associated with institutional investors, Farrar's definition is potentially misleading as it creates ambiguity around the role of banks and investment companies in the governance process. Therefore for the purpose of this research, institutional investors are defined as those professional organisations that manage life insurance policyholders' funds, superannuation funds, unit trusts, group investment funds and all other funds on their own and their clients' behalf, and invest a 
proportion of those funds in equities listed on the NZSX. This definition is broadly in line with the segmentation used by the Reserve Bank (2014).

In June 2011, it was estimated that fund managers controlled $47.5 \%$ of the shares in the New Zealand equity market (Doyle \& Cheong, 2011). Because of their size, geographic location and knowledge, New Zealand institutional investors can play a unique and active role in the corporate governance process. However, their position can create conflicts of interest. The conflicts arise because institutions are effectively caught between the interests of their own investors - who typically require short-term capital gain - and the interests of the companies in which they invest. The companies they invest in mostly view short-term capital gain as unsustainable and detrimental to their business in the long run. An argument has been made that because of this conflict of interest, institutions are unable to effectively participate in the governance process to the extent required to effectively monitor and enforce governance standards (Ingley \& Van der Walt, 2004; Tan \& Keeper, 2008). In practice most institutions appear to be reasonably pragmatic in their approach to governance; using their own research and their informal networks with directors they tend to form their own opinions on governance practices, and use these opinions to make their decisions, which may include actively participating in governance processes of individual companies should they consider it necessary (Chiu \& Monin, 2003). The major ways an institution can influence governance processes are as follows:

- Institution as a board participant. Occasionally an institution will take a block holding in a company and appoint a nominee director to the board who will actively participate in the governance process on behalf of the institution. ${ }^{7}$ However, in general this is not the preferred approach as most institutional investors believe that having nominees on boards

\footnotetext{
${ }^{7}$ Brian Gaynor of Milford Asset Management was on the board of Turners' Car Auctions until 2014, for example.
} 
creates a conflict of interest. Many also consider that governing companies is not their core skill, and that their core business is making investment decisions, not running companies (Chiu \& Monin, 2003).

- Block shareholder. Institutions frequently hold stakes of greater than $5 \%$ of total company equity. In the sample of 40 companies previously discussed, $24(60 \%)$ had a NZ institution holding a stake of $5 \%$ or more. Stakes of this size are harder to accumulate or sell than smaller stakes and are presumably more important than smaller stakes for the institutions concerned. As a result those institutions with block holdings have a strong incentive to monitor the quality of governance. This may explain why firms with such shareholders have superior financial performance relative to firms with other block shareholders (Boone et al., 2011).

- $\quad$ Active trader. Many institutions actively manage funds either on their own account or on behalf of their clients. It is also probable that the majority of trades on the NZX are computer-driven 'algorithmic trades' initiated by institutional investors. While this topic has not been discussed in the New Zealand literature, institutional investors approached by the author acknowledged that this trading occurs, but refused to discuss the details. Further evidence of such trading has been found in an analysis of trading volumes shown in Appendix C. Through these trades institutions can influence short-term share prices, although the degree and scope of influence are unknown. However, there is some suggestion that this trading has been used to manipulate share prices (New Zealand Super Fund, 2015).

- Broker. Many of the institutions that provide share-broking services also provide much of the advice that private investors use to make their investment decisions (Colmar Brunton, 2013). One method of providing this advice is through research brochures that institutions 
publish. These brochures provide an analysis of the company's recent performance, future prospects, and a recommendation to investors to buy, sell or hold the shares.

- Lobbyist. Institutional investors have unique access to CEOs, chairmen, and other key players in the governance process (Chiu \& Monin, 2003). CEOs, senior management and directors generally meet formally with a number of institutions several times a year. In addition it is not uncommon for these parties to meet informally at social events. So institutions have ample opportunity to make their views known to directors and management if they so choose. Equally there is evidence that directors informally 'sound out' key institutions before they raise potentially controversial issues with the shareholders as a whole (Chiu \& Monin, 2003). This is in contrast to the majority of private investors, who generally do not have the opportunity to communicate personally with either management or directors.

- Index-linked investor. Many institutional investors sell investment products to their customers which are tied to certain market indices. As a result, institutional investment decisions are made by following the market, rather than the performance of individual companies. In these circumstances institutional investors would appear to have little incentive to act as owners and participate in governance (Lipton \& Lorsch, 1992).

The institutional investment community in New Zealand is quite small; most of the key players know each other and meet regularly at events such as company briefings. Institutions occasionally work together to lobby boards when they wish to influence the governance process (Chiu \& Monin, 2003). 


\subsubsection{Foreign investors}

Foreign ownership is a feature of share markets in all developed countries. As Figure 8 shows, foreign ownership in the NZ market is at a moderate level relative to some other developed countries.

\section{Figure 8}

Share of equities owned by foreign investors

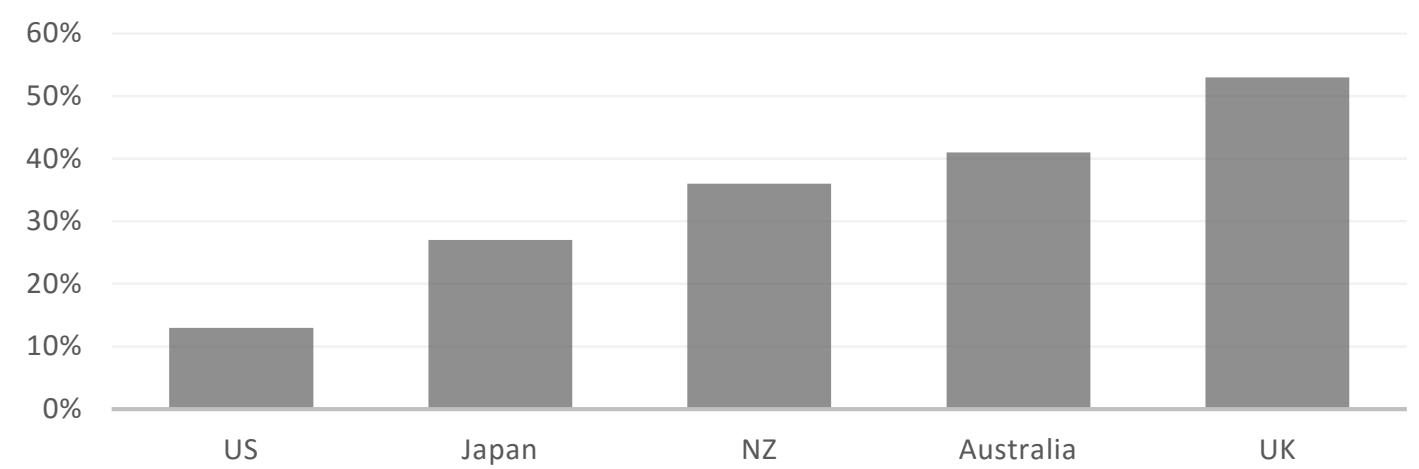

Source: Doyle \& Cheong (2011).

The foreign-owned share of the New Zealand equities market has been declining steadily. In 1997 approximately $60 \%$ of the NZ equities market was owned by foreign investors, and by 2011 this had dropped to 36\% (Doyle \& Cheong, 2011). Precise data on the level and nature of foreign ownership are difficult to derive because companies are not obliged to track or report on levels of foreign ownership. Overseas-based institutional investors make up the vast majority of foreign investment in the NZX (Doyle \& Cheong, 2011). From the statutory shareholder information published in annual reports it is possible to identify foreign owners with a greater than $5 \%$ share of a company. An analysis of the sample 40 companies identified 11 companies where overseas investors held a strategic stake of at least $10 \%$. Of these investments nine were held by institutional 
investors and two by private investors. None of the institutional investors held a stake greater than $19.9 \%$ of the total equity. Table 14 shows New Zealand companies with foreign block shareholders.

\section{Table 14}

Companies with foreign block shareholders

\begin{tabular}{lrlrl} 
& $\begin{array}{r}\text { Market cap } \\
\text { Company }\end{array}$ & $\begin{array}{l}\text { Shares on } \\
\text { issue }\end{array}$ & $\begin{array}{l}\text { Shares traded } \\
\text { in July '13 }\end{array}$ & $\begin{array}{l}\text { Percentage of } \\
\text { total shares } \\
\text { traded in July '13 }\end{array}$ \\
\hline DNZ Property & 455,376 & $\mathbf{2 9 3 , 7 9 1 , 1 3 5}$ & $155,675,168$ & $53 \%$ \\
Ebos & $1,363,920$ & $147,610,382$ & $39,997,650$ & $27 \%$ \\
Fisher and Paykel Healthcare & $1,979,848$ & $546,838,267$ & $590,283,078$ & $108 \%$ \\
Fletcher Building & $6,410,807$ & $687,854,788$ & $884,001,558$ & $129 \%$ \\
Kiwi Income Property Trust & $1,111,800$ & $1,006,153,978$ & $399,218,930$ & $40 \%$ \\
Metlifecare & 958,206 & $210,594,691$ & $73,754,362$ & $35 \%$ \\
Nuplex & 665,703 & $198,125,827$ & $197,893,080$ & $100 \%$ \\
Sealegs & 53,342 & $1,481,733,227$ & $9,928,270$ & $1 \%$ \\
Telecom & $4,104,209$ & $1,822,303,137$ & $3,124,057,288$ & $171 \%$ \\
Tenon & 85,398 & $65,690,681$ & $2,627,240$ & $4 \%$ \\
Xero & $4,208,608$ & $127,523,561$ & $29,924,422$ & $\mathbf{2 3 \%}$ \\
Market average & $\mathbf{6 8 0 , 7 0 4}$ & $\mathbf{2 9 9 , 3 5 7 , 0 3 9}$ & $\mathbf{5 0 0 , 6 6 9 , 1 8 6}$ & $\mathbf{1 6 7 \%}$ \\
Median & $\mathbf{2 2 7 9 0 2}$ & $\mathbf{1 5 3 , 9 9 7 , 2 8 6}$ & $\mathbf{1 5 5 , 6 7 5 , 1 6 8}$ & $\mathbf{1 0 1 \%}$
\end{tabular}

Note: Companies with foreign private block holders are shown in italics; all other companies have foreign institutional investors.

Several researchers have observed that in other jurisdictions foreign institutional investors tend to take minority stakes in companies that are actively traded (Douma, George and Kabir 2006;

Dahlquist \& Robertsson, 2001; Ferreira \& Matos, 2008). Table 14 also shows the shares traded in these companies in July 2013. Although representing only a one-month snapshot, these data are broadly consistent with observations by Douma et al., (2006) and suggest that, in general, foreign institutions may adopt a similar strategy when investing in New Zealand public companies as they do elsewhere in the world. However, no research appears to have been specifically conducted into the aspirations and behaviours of overseas-based equity investors. 
From a governance perspective foreign investors can be seen as a catalyst for introducing international practices to New Zealand governance. For example, the International Financial Reporting Standards (IFRS) were adopted primarily because Australia (the biggest foreign investor in NZ) made the decision to adopt this standard (Bradbury \& Van Zij1, 2006).

\subsubsection{Public investors}

Public investors are shareholders who are ultimately controlled by either local or national government. There are some behaviours frequently observed within the group that suggest that they are different to other block holders in the way they approach corporate governance. For example, they tend to be very long-term investors and any decision to sell their holdings is generally signalled publically well in advance of the actual sale (Huang, Watson \& Chen, 2013). It is also argued that government is a poor block shareholder because of its preference for social and political goals as opposed to profit maximisation, and because it uses its influence to appoint directors and senior managers based on political affiliations rather than commercial ability (Boone et al., 2011). Others, however, have found that in cases where companies are partially privatised and the government remains a substantial shareholder (as has happened recently with electricity companies in New Zealand), there has been a positive impact on the efficiency and profitability of the companies concerned (Gupta, 2005).

\subsubsection{Block investors}

Block holders have been identified as playing a key role in the internal governance process (Shleifer \& Vishny, 1996). Block holders are defined as entities that hold a 5\% or greater stake in an NZXlisted company (Securities Markets Act 1988). As shareholding size increases, the ability to influence the board of the company increases (Maume \& Walker, 2012) and, because of the small 
size of the NZ market, the ability to quickly sell the shareholding and exit the company decreases. This factor may give block holders stronger incentives to monitor and influence governance processes. Therefore the size and number of block shareholders have the potential to influence shareholder and director expectations of boards.

With regard to the influence that a block shareholder can have over a firm, shareholding thresholds of $10 \%$ and $20 \%$ are considered significant. A $10 \%$ shareholding is given to be the minimum threshold for a strategic stake in a firm. This is the approximate level of shareholding that an individual shareholder must have in order to influence the board. A $20 \%$ shareholding is widely considered to be a sufficient shareholding to control a public company (Maume \& Walker, 2012). A controlling shareholder has the ability to appoint or replace directors and so may be more inclined to direct a board, whereas a shareholder with a strategic stake lacks this ability and must adopt other strategies to influence a board. The presence of a controlling shareholder has been found to be associated with higher shareholder valuations (Yeh, 2005). In New Zealand, Bhabra (2007) has found evidence that the relationship between company performance and insider ownership is nonlinear, with a negative relationship for block holdings of between $14 \%$ and $40 \%$ and a positive relationship outside of these ranges.

Block holders can be further segmented into investor groups discussed previously in this chapter, i.e. private investors, institutional investors and public entities. It is likely that investors in each of these groups have common interests and motivations which differ from those of the other groups (Boone et al., 2011). However, precisely what these interests and motivations are has yet to be fully established.

Table 15, based on a survey of 40 companies, segments block shareholders by the size of their shareholding, their investor type (private, institutional, or public) and their location (NZ based or international). 


\section{Table 15}

Distribution of NZSX block holding shareholders 2013

\begin{tabular}{l|rrr|rrr} 
& \multicolumn{3}{|c|}{ NZ } & \multicolumn{3}{|c}{ International } \\
Block size & $\begin{array}{r}\text { Private } \\
\text { investors }\end{array}$ & $\begin{array}{rlrr}\text { Institutional } \\
\text { investors }\end{array}$ & $\begin{array}{r}\text { Public } \\
\text { investors }\end{array}$ & $\begin{array}{r}\text { Private } \\
\text { investors }\end{array}$ & $\begin{array}{r}\text { Institutional } \\
\text { investors }\end{array}$ & $\begin{array}{r}\text { Public } \\
\text { investors }\end{array}$ \\
\hline $5-9.9 \%$ & $30 \%$ & $48 \%$ & $3 \%$ & $5 \%$ & $15 \%$ & $0 \%$ \\
$10-19.9 \%$ & $13 \%$ & $18 \%$ & $3 \%$ & $3 \%$ & $18 \%$ & $0 \%$ \\
$20 \%+$ & $15 \%$ & $5 \%$ & $8 \%$ & $5 \%$ & $3 \%$ & $0 \%$ \\
Totals & $\mathbf{5 8 \%}$ & $\mathbf{7 1 \%}$ & $\mathbf{1 4 \%}$ & $\mathbf{1 3} \%$ & $\mathbf{3 5 \%}$ & $\mathbf{0} \%$
\end{tabular}

Sample size: 40 companies.

The table highlights some structural aspects of the NZ market that may influence shareholder and directors expectations of boards. Thirty-six per cent of companies reviewed have a controlling shareholder, so it is difficult to make any generalisations about the influence of shareholders across the NZSX market. Seventy per cent of companies reviewed have at least one New Zealand institution on their register holding at least $5 \%$ of the available shares. Unlike private block holders, who often appear to be long-term holders, these shareholders are likely to trade their shareholdings. This places institutions in a hugely influential position because by increasing or decreasing their shareholding they can influence the share price and hence the cost of the company's capital. Therefore how they engage with companies has a major influence on governance in New Zealand and on shareholders' and directors' expectations of boards.

\subsection{New Zealand Company Directors}

The question of what are the appropriate attributes and qualifications for directors has been debated long and hard. Adam Smith raises the subject in his classic The Wealth of Nations (1776), and the specific issue that he raised (director-shareholder alignment) is still debated today. Both the 
government, through the Companies Act 1993, and NZX, through its listing rules, have set minimum qualifications for directors (NZX, 2013). The Institute of Directors also has a desire to set higher minimum standards and certification for directors (which could only be achieved by attending their courses and paying the requisite fees).

The qualifications and attributes of NZ directors constitute an area that has been researched extensively in the past (Boyle \& Ji, 1995; Orr, Emanuel \& Wong, 2005). The research has generally focused on specific measurable attributes, such as director independence, tenure, gender, and workload. This section updates some of the previous research in order to show trends from 1995 through to 2013. In addition to updating previous research, some new research has been conducted that examines directors' human capital contribution to boards and their country of residence. The research into human capital is included because it has been identified as a key element enabling boards to perform their functions, yet has been little researched (Kor \& Sundaramurthy, 2008). The country of residence research is included because there is general debate around the globalisation of $\mathrm{NZ}$ business and this research presents an opportunity to lead the debate in an area not previously researched.

\subsubsection{Executive directors}

In New Zealand the number of executives who sit on boards is declining. Table 16 shows the percentage of companies with the CEO on the board and the percentage of all NZSX-listed company board seats occupied by all executives (including CEOs). 


\section{Table 16}

Share of executive directors on NZSX-listed company boards

\section{Executive Directors}

\begin{tabular}{lrrr} 
Year & 1995 & 2010 & 2013 \\
\hline Companies with CEO on board & $64 \%$ & $67 \%$ & $63 \%$ \\
Executive share of total directors & $22 \%$ & $17 \%$ & $12 \%$ \\
Sample size & 86 & 117 & 112
\end{tabular}

Source: 1995 and 2010 data from Boyle \& Ji (2011). 2013 data sourced from NZX company website.

Approximately two-thirds of NZSX companies have appointed the CEO to the board; this ratio has remained relatively constant since 1995 . However, over the same period the total number of executives on boards has declined by almost half, showing that executives other than CEOs have become less common on boards. In 2013 there were 10 executives on boards who were not the CEO of their respective company, and of these 10 , nine were either substantial shareholders in their own right or had close ties with a substantial shareholder. It would appear, then, that executives other than CEOs can no longer hold a seat on the board by virtue of their position within the company. This is a significant trend as it suggests that the gap between management and governance is continuing to widen and that management is likely to be having less influence over the governance process. This change has occurred without any significant public debate, which suggests that the change has been driven by directors themselves. Given that almost all directors are appointed with an endorsement from the existing board, it may also suggest that independent directors are exerting more control over boards (with Table 16 showing that they are occupying a larger proportion of the available board seats). 
There are no longer any NZSX-listed companies with a CEO who also holds the position of chairman of the board. This conforms to the Security Commission (2011) best practice guidelines. However, it contrasts with the situation in the US, where it is not uncommon for an individual to fill the roles of both CEO and chairman - which highlights another example of how governance practices can differ between Anglo-Saxon jurisdictions (Larcker \& Tayan, 2011, p. 132).

\subsubsection{Independent directors}

The NZX defines an independent director as a director who is not an executive of the company and who does not have any direct or indirect interest or relationship that could reasonably influence, in a material way, the director's decisions in relation to the company (NZX, rule 3.3.1c, 2013). Directors who do not meet this requirement are referred to as inside directors. In New Zealand the debate around the value and role of independent directors reached its zenith in 2003, when the NZX introduced a requirement that a company appoint a minimum of two independent directors, or, if there are eight or more directors, one-third must be independent (NZX, rule 3.3.1c, 2013). This change seemed to satisfy shareholders as the debate in the popular press abated shortly after this decision. However, subsequent research shows that in New Zealand large numbers of independent directors on boards are detrimental to company performance (Goldfinch, 2004; Orr et al., 2005; Koerniadi \& Tourani-Rad, 2012).

Table 17 shows that the overall percentage of independent directors on NZSX-listed company boards jumped between 1995 and 2010; this was probably a consequence of the NZX rule change. While the overall number of independent directors has remained constant since 2010 the percentage of boards that have a majority of independent directors has continued to increase. At the extreme there are now six companies which have completely independent boards. This trend shows that boards are increasingly weakening or breaking their direct ties with major shareholders. It is a 
significant trend, because as these ties break, the gap between shareholders and the business widens and many of the issues first identified in the US by Berle \& Means (1932) become more apparent.

\section{Table 17}

Share of independent directors on NZSX-listed company boards

\section{Independent Directors}

\begin{tabular}{lrrr} 
Year & 1995 & 2010 & 2013 \\
\hline Independent directors & $55 \%$ & $62 \%$ & $62 \%$ \\
Independent majority & $46 \%$ & $63 \%$ & $75 \%$ \\
Sample size & 59 & 115 & 112
\end{tabular}

Source: 1995 and 2010 data from Boyle \& Ji (2011), 2013 data is from NZX website December 2013.

\subsubsection{Tenure}

The length of time directors serve on a board is an issue that is of concern to directors and shareholders alike (Mitchell et al., 2013). NZX listing rules require that directors other than the managing director must present themselves for re-election every three years; however, neither company law nor the NZX places a limit on the number of times a director can stand for re-election. A review of the constitutions and board charters of the sample 40 NZX companies previously discussed did not identify any company that limited opportunities for re-election. Table 18 shows the distribution of tenure of all NZSX directors as at November 2013.

\section{Table 18}

NZSX-listed company director tenure

\section{Years since appointment}

\begin{tabular}{lrrrrrr} 
Years served & $<3$ & $3-7$ & $8-12$ & $13-17$ & $18-21$ & $>22$ \\
\hline Number of directors & 251 & 227 & 124 & 23 & 43 & 3 \\
Share & $37 \%$ & $34 \%$ & $18 \%$ & $3 \%$ & $6 \%$ & $0 \%$
\end{tabular}


Across all NZX-listed companies, the sitting directors have served on their current company boards for an average of 6.0 years, with the median term served 4.1 years.

Australian companies with independent directors who have served for more than five years have been shown to have a superior ROE compared to those boards with less experienced directors, according to Mitchell et al., (2013), who suggest this could indicate that corporate memory and experience can enhance returns. Table 19 shows the trend in director tenure since 1995.

\section{Table 19}

Trend in share of NZSX-listed company directors who have served more than 5 years

\begin{tabular}{lrrr} 
& 1995 & 2010 & 2013 \\
\hline Number of directors (\% share) & 34 & 56 & 43 \\
Sample size (companies) & 86 & 117 & 112
\end{tabular}

Source: 1995 and 2010 data from Boyle \& Ji (2011).

As Table 19 shows, the share of long-serving directors has declined between 2010 and 2013. One possible, although unsubstantiated, explanation for this decline is that it is related to the GFC and the hardened regulatory environment, along with the ensuing negative publicity that public company directors received. Experienced directors may simply have decided the risk of remaining a public company director outweighed the benefits.

\subsubsection{Gender diversity}

Gender diversity is currently one of the most discussed aspects of New Zealand corporate governance. Articles on the subject regularly appear in the popular press; organisations have been established specifically to promote women on boards (The 25\% Group and Women on Boards NZ), 
and the government has adopted an affirmative policy (Ministry of Women, 2014). NZX has recently mandated that companies report on the number of women on their board (NZX 2013). A number of public company directors have publicly stated their support for increasing the number of women on boards and, as will be shown, the issue is regularly raised by shareholders at company ASMs. Almost all of the public discussion on the topic supports appointing more women to boards. Researchers have, however, found scant evidence to suggest that gender mix has a material influence on the performance of New Zealand boards (Van der Walt \& Ingley, 2003; Van der, Walt Ingley, Shergill \& Townsend, 2006). In fact Fauzi \& Locke (2012) found that in the companies they reviewed, those with a higher proportion of women on boards had a poorer financial performance than those with fewer or no women. These findings arguably reflect as much on the methodology employed as on the performance of the boards themselves, given that the research uses a traditional black box style methodology and is therefore subject to the limitations outlined by Aguilera and Jackson (2003) and Finkelstein and Mooney (2003).

In 2013, 87 (13\%) of New Zealand's public company directors were women. As Table 20 shows, the number of boards with at least one female director has been progressively increasing over the period from 1995 to 2013. 


\section{Table 20}

Trend in share of female directors of NZSX-listed companies

\begin{tabular}{lrrr} 
& 1995 & 2010 & 2013 \\
\hline $\begin{array}{lrrr}\text { Boards with at least one female } \\
\text { director }\end{array}$ & 10 & 40 & 59 \\
Share (\%) & 11.6 & 34.2 & 52.7 \\
Sample size & 86 & 117 & 112
\end{tabular}

Source: 1995 and 2010 data from Boyle \& Ji (2011).

The mean size of an all-male board is 5.5 (Std. Dev. 1.49) members, and the mean size of boards that include female directors is 6.4 (Std. Dev. 1.66). An ANOVA test shows that this difference is statistically significant $(\mathrm{t}$-statistic $=5.003)$. One possible explanation for this larger size is that some boards are responding to external pressure by increasing the size of their board to facilitate a female director.

\subsubsection{Domicile}

An issue that does not yet feature in the literature on New Zealand governance, but is starting to be discussed in the popular press, is the potential benefit to companies of having directors based overseas (Gaynor, 2011; Rural News, 2011). The argument in favour of overseas directors is that they bring a different perspective to business, and they potentially have networks that can assist the company in specific international markets (Adams et al., 2010). Research from other jurisdictions suggests that there may also be downsides to companies hiring overseas directors; these include poor board meeting attendance records, a tendency to over-remunerate CEOs, and a higher likelihood of financial misreporting (Masulis, Wang \& Xie, 2012). Table 21 shows where New Zealand's public company directors are based. 


\section{Table 21}

Domicile of directors of NZSX-listed companies 2013

\begin{tabular}{lrr} 
& Directors & Share \\
\hline New Zealand & 535 & $80 \%$ \\
Australia & 81 & $12 \%$ \\
Other offshore locations & 56 & $8 \%$ \\
Total & 672 & $100 \%$ \\
Sample size & 112 &
\end{tabular}

As Table 21 shows, approximately $20 \%$ of New Zealand's company directors are based overseas, with the majority being located in Australia. These overseas-based directors are widely distributed throughout NZ listed companies and, as Table 22 shows, over half (54\%) of all NZSX-listed companies now have at least one director based overseas. However, it should also be noted that not all of the international directors are recruited for their offshore experience, as a significant number appear to be appointed primarily as nominees of substantial offshore block shareholders.

\section{Table 22}

Share of NZSX-listed companies with an overseas based director (2013)

\begin{tabular}{lrr} 
& Companies & \% of NZSX \\
\hline Any international director & 61 & 54 \\
Australian directors & 45 & 40 \\
Other international directors & 29 & 26 \\
Sample size & 112 &
\end{tabular}

Note: some companies have both Australian and other international directors. 
Ten companies ( $9 \%$ of the total) have a majority of their directors based offshore - a review of their board charters does not suggest any systemic differences in their governance practices relative to companies with New Zealand-based shareholders.

\subsubsection{Busy directors}

Directors who sit on multiple boards can provide valuable experience and prestige to companies, but their workload can also result in less rigorous monitoring and control (Boyle \& Ji, 2011). In New Zealand, 568 directors fill the 672 board seats of NZSX-listed company boards, with 71 directors (13\%) sitting on two or more boards. By comparison the US has some 29,000 public company directors, $17 \%$ of whom sit on two or more boards (Larcker \& Tayan, 2013, pp. 151-154). This suggests that New Zealand directors are not overly busy relative to their US counterparts - a sentiment confirmed by Boyle \& Ji (2011). However, some New Zealand directors also sit on private company boards, so in practice they may be busier than these statistics suggest. Table 23 shows how many NZSX-listed company boards NZSX directors sit on.

\section{Table 23}

Summary of NZSX directors who sit on multiple boards (2013)

\begin{tabular}{lrrrrr} 
Number of boards & 1 & 2 & 3 & 4 & 5 \\
\hline Directors & 496 & 46 & 17 & 7 & 1 \\
Share (\%) & 87 & 8 & 3 & 1 & 0 \\
Sample size & 567 & & & &
\end{tabular}

Source: NZ Companies Office Database

\subsubsection{Director human capital}

The human capital that individual directors contribute to the board appears to be an important factor in determining shareholder and director expectations of boards. This may be because directors' human capital has been shown to affect company performance (Westphal \& Fredrickson, 2001). 
The issue is discussed in the New Zealand literature, where the importance of director human capital is acknowledged and concerns are raised regarding the availability of suitably qualified directors (Goldfinch, 2004; Van der Walt \& Ingley, 2003). Furthermore, most companies choose to publish director biographies in their annual reports, an action which suggests that both shareholders and directors value the human capital directors contribute to the board. To the author's knowledge comprehensive research into the background of NZSX directors has not previously been conducted.

To examine the human capital that directors contribute to boards, the backgrounds of all directors appointed to NZX main board companies in 2013 were examined. The directors were identified from data on the Companies Office director database. Data were compiled from the following public sources: company annual reports, NZX notifications, the Companies Office website, company websites, and the social networking site Linkedin. All data was taken 'at face value' and was not cross-checked with other sources to confirm its veracity. The variables selected were based on a taxonomy used by Singh et al., (2008). The following attributes were selected for analysis:

- Academic qualifications. These were drawn from the data on academic qualifications that directors chose to share publicly.

- Commercial experience. This is based on the most senior commercial position the directors claim to have held. Partners in law or accountancy firms have been included in the general manager category, given the blend of commercial and professional expertise required by these roles.

- Professional experience. This includes any experience in the commercial profession in which the director claims to have practised. Financial professional experience includes accounting, auditing and investment banking. Legal experience has also been defined quite broadly and is not confined to commercial law; so this category 
includes any director who claims to have any type of legal practice in their background.

- International experience. This is categorised as having had senior management experience based outside of New Zealand.

- Prior public board experience. This can include experience as a director of a company listed on any bourse.

- Celebrity status. Celebrity directors command a degree of public fascination in the mainstream media and some may have been appointed to the position of director primarily for this reason rather than for their commercial prowess and experience; ex-politicians have featured in this category in the past.

- Industry experience. This comprises senior management experience based outside of New Zealand.

- Domicile. This is based on the home addresses of directors as recorded in the NZ Companies Office database.

Two segmentation analyses were performed on the data, one comparing the characteristics of inside directors with independent directors and the other comparing male directors with female directors. As will be shown, these segmentation analyses provide further insights into the expectations that directors and shareholders have of boards.

The 2013 directors

In 2013 a total of 79 directors were appointed to NZSX boards. Three of these new appointments resigned within the year and have been omitted from the analysis. Another director has chosen not to reveal anything of his background other than that he is an investor, so he too has 
been omitted from the analysis. The remaining 75 board appointments have all been analysed.

Collectively these directors fill $11 \%$ of the total NZSX board seats.

It is important to appreciate that data were only collected from directors who were appointed in 2013. These directors have been appointed after a period where there has been widespread concern over the actions and behaviours of some directors (Cardow \& Wilson, 2015) and some substantial change in the regulatory environment (see section 4.1). When the US share markets went through a similar phase, board composition changed (Linck, Netter \& Yang, 2008). It is therefore possible that a change has occurred in the composition of New Zealand boards, so some caution must be applied when drawing conclusions about the entire population of directors from these data. However, what can be determined from the data is some insights into the attributes that directors currently value in their peers.

\section{Results}

Table 24 summarises the findings.

\section{Table 24}

2013 board appointments: directors' human capital attributes

\begin{tabular}{|c|c|c|c|c|c|c|c|c|}
\hline \multicolumn{3}{|c|}{ Academic qualifications } & \multicolumn{3}{|c|}{ Commercial experience } & \multicolumn{3}{|c|}{ Professional experience } \\
\hline & & & CEO & 42 & $56 \%$ & Finance & 36 & $48 \%$ \\
\hline Postgraduate & 28 & $37 \%$ & GM & 9 & $12 \%$ & Legal & 13 & $17 \%$ \\
\hline Bachelor & 17 & $23 \%$ & Senior executive & 23 & $31 \%$ & Other & 26 & $35 \%$ \\
\hline No information & 30 & $40 \%$ & No information & 1 & $1 \%$ & No information & 0 & $0 \%$ \\
\hline Total & 75 & $100 \%$ & Total & 75 & $100 \%$ & Total & 75 & $100 \%$ \\
\hline \multicolumn{3}{|c|}{ International experience } & \multicolumn{3}{|c|}{ Prior public board experience } & \multicolumn{3}{|c|}{ Celebrity director } \\
\hline Yes & 48 & $64 \%$ & Yes & 30 & $40 \%$ & Yes & 0 & $0 \%$ \\
\hline No Information & 27 & $36 \%$ & No Information & 45 & $60 \%$ & No & 75 & $100 \%$ \\
\hline Total & 75 & $100 \%$ & Total & 75 & $100 \%$ & Total & 75 & $100 \%$ \\
\hline \multicolumn{3}{|c|}{ Industry experience } & \multicolumn{3}{|c|}{ Based overseas } & & & \\
\hline Yes & 47 & $63 \%$ & Yes & 13 & $17 \%$ & & & \\
\hline No & 28 & $37 \%$ & No & 62 & $83 \%$ & & & \\
\hline Total & 75 & $100 \%$ & Total & 75 & $100 \%$ & & & \\
\hline
\end{tabular}


The directors appointed in 2013 were very highly qualified, with $37 \%$ claiming postgraduate qualifications. Overall $60 \%$ of directors claimed a university qualification compared to $20.8 \%$ of the general population (Statistics NZ, 2013). While it is difficult to infer much from these statistics directly, as will be shown in subsequent sections, when the sample is segmented significant differences appear in the qualifications of some segments. These directors had extensive commercial experience, with over half claiming a prior CEO position. No current CEOs of NZSX companies were appointed to the boards of other listed companies that year. In the US CEOs are regularly appointed to the boards of other companies; this is because of the certification effect that CEOs bring to the appointing firm (Fahlenbrach et al., 2010) and their ability to increase growth (Fich, 2005). No celebrity directors were appointed in 2013. One event in particular may have had a strong influence on this outcome: the high-profile court case involving two former justice ministers turned company directors (Cardow \& Wilson, 2015), and the ensuing publicity, may have led boards to conclude that political celebrities no longer add credibility to companies. International experience appears to be highly regarded by boards, with $64 \%$ of the directors asserting international experience at a senior management level, making it the most prevalent feature analysed. International experience also features prominently in directors' résumés and in press releases regarding directorial appointments, which suggests that it is considered prestigious and adds to directors' reputations. Sixty-three per cent of directors surveyed had prior experience in the same industry, suggesting that directors also place a high value on prior industry experience.

\section{Inside and independent director comparison}

Inside directors were identified either by being reported as such in their company annual reports or in notices filed on the NZX website (NZX.com). There is evidence to suggest that independent directors are usually nominated by the CEO and fellow board members (Shivdasani \& Yermack, 1999; Westphal \& Zajac, 1995), while inside directors are generally nominated by one or more substantial shareholders. So by comparing the attributes of inside and independent directors 
insights could be gleaned into the relative importance that major shareholders and directors place on these attributes. Table 25 show this comparison; chi-square tests were performed to test the significance of any differences between the segments. Where the difference between the two groups is considered significant $(\mathrm{p}<0.05)$, the chi-square result is highlighted in bold.

\section{Table 25}

Comparison between the expertise of inside and independent directors of NZSX-listed companies

$$
\begin{array}{rrrr}
\text { Inside Independent } & \text { Inside } & \text { Independent } & \text { Chi test } \\
& (\%) & (\%) & (p)
\end{array}
$$

\section{Academic qualifications}

\begin{tabular}{rrrrrr} 
Postgraduate & 12 & 16 & $57 \%$ & $30 \%$ & $\mathbf{0 . 0 2 7}$ \\
Bachelor & 3 & 14 & $14 \%$ & $26 \%$ & $\mathbf{0 . 0 0 7}$ \\
No information & 6 & 24 & $29 \%$ & $44 \%$ & \\
\cline { 2 - 5 } Total & 21 & 54 & $100 \%$ & $100 \%$ &
\end{tabular}

Commercial experience

\begin{tabular}{rrrrrr} 
CEO & 12 & 30 & $57 \%$ & $56 \%$ & 0.901 \\
GM & 3 & 6 & $14 \%$ & $11 \%$ & 0.704 \\
Senior executive & 6 & 17 & $29 \%$ & $31 \%$ & 0.806 \\
No information & 0 & 1 & $0 \%$ & $2 \%$ & \\
\cline { 2 - 5 } Total & 21 & 54 & $100 \%$ & $100 \%$ &
\end{tabular}

\section{Professional experience}

\begin{tabular}{rrrrrr} 
Finance & 9 & 27 & $43 \%$ & $50 \%$ & 0.578 \\
Legal & 3 & 10 & $14 \%$ & $19 \%$ & 0.664 \\
Other & 9 & 17 & $43 \%$ & $31 \%$ & \\
\cline { 2 - 5 } Total & 21 & 54 & $100 \%$ & $100 \%$ &
\end{tabular}

Previous public board experience

\begin{tabular}{rrrrr} 
Yes & 6 & 24 & $29 \%$ & $44 \%$ \\
No Information & 15 & 30 & $71 \%$ & $56 \%$ \\
\cline { 2 - 5 } Total & 21 & 54 & $100 \%$ & $100 \%$
\end{tabular}

International experience

\begin{tabular}{rrrrr} 
Yes & 17 & 31 & $81 \%$ & $57 \%$ \\
No Information & 4 & 23 & $19 \%$ & $43 \%$ \\
\cline { 2 - 5 } Total & 21 & 54 & $100 \%$ & $100 \%$
\end{tabular}

\section{Based overseas}

\begin{tabular}{rrrrr} 
Yes & 7 & 6 & $33 \%$ & $11 \%$ \\
No & 14 & 48 & $67 \%$ & $89 \%$ \\
\cline { 2 - 5 } Total & 21 & 54 & $100 \%$ & $100 \%$
\end{tabular}

Industry experience

\begin{tabular}{rrrrr} 
Yes & 17 & 30 & $77 \%$ & $52 \%$ \\
No & 4 & 24 & $33 \%$ & $48 \%$ \\
\cline { 2 - 5 } Total & 21 & 54 & $100 \%$ & $100 \%$
\end{tabular}

0.208

0.056

0.022

0.004 
Table 25 suggests that there are significant differences between independent and inside directors in terms of their academic qualifications, location, and previous industry experience. Inside directors tend to be higher qualified than internal directors. Fifty-seven per cent of the inside directors sampled hold postgraduate qualifications compared to $30 \%$ of independent directors. Inside directors also appear to have stronger international links than independent directors. Thirty-three per cent of internal directors surveyed are based overseas compared to $11 \%$ of independent directors. A possible explanation for this is that many overseas-based investors prefer to have a representative on the board of companies in which they hold a significant investment. Inside directors are also more likely to have industry experience. There does not appear to be any significant difference between inside and independent directors in terms of their commercial and professional experience or their previous board experience. This suggests that both major shareholders and directors place similar value on these attributes.

\section{Gender comparison}

As discussed in section 4.5.4 the appointment of female directors to boards is a regularly debated corporate governance topic. Comparing the attributes of male and female directors will show if boards have chosen to compromise on any of these attributes in order to recruit women directors. This comparison therefore provides evidence that will either support or refute the claim that there is a shortage of suitably qualified women (Whittaker, 2012). Table 26 compares gender attributes of directors. 


\section{Table 26}

Comparison of the expertise of male and female directors of NZSX-listed companies

\begin{tabular}{|c|c|c|c|c|c|}
\hline & Male & Female & Male & Female & Chi Test (p) \\
\hline \multicolumn{6}{|c|}{ Academic qualifications } \\
\hline Postgraduate & 20 & 8 & $34 \%$ & $47 \%$ & 0.346 \\
\hline Bachelor & 13 & 4 & $22 \%$ & $24 \%$ & 0.923 \\
\hline No information & 25 & 5 & $43 \%$ & $29 \%$ & \\
\hline Total & 58 & 17 & $100 \%$ & $100 \%$ & \\
\hline \multicolumn{6}{|c|}{ Commercial experience } \\
\hline CEO & 33 & 9 & $57 \%$ & $53 \%$ & 0.059 \\
\hline GM & 7 & 2 & $12 \%$ & $12 \%$ & 0.972 \\
\hline Senior executive & 17 & 6 & $29 \%$ & $35 \%$ & 0.638 \\
\hline No information & 1 & 0 & $2 \%$ & $0 \%$ & \\
\hline Total & 58 & 17 & $100 \%$ & $100 \%$ & \\
\hline \multicolumn{6}{|c|}{ Professional experience } \\
\hline Finance & 33 & 3 & $57 \%$ & $18 \%$ & 0.004 \\
\hline Legal & 8 & 5 & $14 \%$ & $29 \%$ & 0.135 \\
\hline Other & 17 & 9 & $29 \%$ & $53 \%$ & \\
\hline Total & 58 & 17 & $100 \%$ & $100 \%$ & \\
\hline \multicolumn{6}{|c|}{ Previous public board experience } \\
\hline Yes & 21 & 9 & $36 \%$ & $53 \%$ & 0.216 \\
\hline No information & 37 & 8 & $64 \%$ & $47 \%$ & \\
\hline Total & 58 & 17 & $100 \%$ & $100 \%$ & \\
\hline \multicolumn{6}{|c|}{ International experience } \\
\hline Yes & 38 & 10 & $66 \%$ & $59 \%$ & 0.613 \\
\hline No information & 20 & 7 & $34 \%$ & $41 \%$ & \\
\hline Total & 58 & 17 & $100 \%$ & $100 \%$ & \\
\hline \multicolumn{6}{|l|}{ Based overseas } \\
\hline Yes & 10 & 3 & $17 \%$ & $18 \%$ & 0.969 \\
\hline No & 48 & 14 & $83 \%$ & $82 \%$ & \\
\hline Total & 58 & 17 & $100 \%$ & $100 \%$ & \\
\hline \multicolumn{6}{|l|}{ Director status } \\
\hline Inside & 18 & 1 & $31 \%$ & $6 \%$ & 0.036 \\
\hline Independent & 40 & 16 & $69 \%$ & $94 \%$ & \\
\hline total & 58 & 17 & $100 \%$ & $100 \%$ & \\
\hline
\end{tabular}

The table shows that, overall, the women who were appointed to boards in 2013 were as qualified and experienced as their male counterparts. This is similar to the findings of Singh et al., (2008), who conducted like research in the UK. There are two areas where there is a statistically significant difference between the attributes of male and female directors. First, $57 \%$ of male directors have a 
finance background, versus $18 \%$ of women directors. This is a curious finding given that women hold $28 \%$ of the CFO positions in NZ (Grant Thornton, 2012), so it can be reasonably assumed there is a large pool of prospective candidates with this experience from which directors could be drawn. The second area where there is a significant difference is in the appointment of independent directors: women comprised $30 \%$ of independent directors but only $5 \%$ of inside directors. As discussed previously there is evidence to suggest that CEOs and directors influence the appointment of independent directors (Shivdasani \& Yermack, 1999; Westphal \& Zajac, 1995), while inside directors are generally nominated by one or more substantial shareholders, so this suggests a significant difference in the actions of these two groups. This in turn may suggest that directors and major shareholders have different expectations with respect to the role of women on boards.

\section{Discussion}

Most directors appointed in 2013 had either a finance background or were former CEOs; most had international experience or lived offshore; and postgraduate degrees are also common. Men outnumber women about four to one and almost all female directors are independent. The cohort also has extensive commercial experience.

That over half the directors appointed stated that they had previously held a CEO position is significant. The CEO-board relationship is considered key to the overall success of the governance process (Kakabadse, Kakabadse \& Barratt, 2006). So having board members who have previously served as CEOs could be considered an advantage by other directors, as not only will these board members be able to empathise and advise the CEO from a position of experience but, as 'poachers turned game keepers', they are well positioned to control any managerial opportunism that may arise (Shen, 2003). And from a shareholder perspective, having former CEOs on boards could also be seen as significant because many former CEOs have a public reputation linked to the companies they formerly managed, so they can be seen as endorsing the company's future prospects (Fich, 2005; Ong \& Wan, 2008). 
Forty per cent of directors surveyed stated that they had previous listed company board experience. From this data it is unclear if boards specifically recruit for directors with this experience or if previous board experience is an incidental factor in general recruitment. However, a compelling reason for boards to appoint directors with strong public company governance experience is that the costs associated with being penalised if they do not comply with some governance regulations is substantial. This is a significant risk for directors as both the New Zealand Market Disciplinary Tribunal (2013) and the Financial Markets Authority (2014) reported an increasing number of compliance-related cases. Of the 28 directors lacking industry experience, all but one has prior experience as a public company director. Given that the other attributes that these directors possess (such as financial market experience) are not in short supply, this is circumstantial evidence that directors specifically appoint directors with previous board experience.

While the attributes discussed in this section undoubtedly influence director selection, it is quite probable that they are not the only criteria; and indeed other factors, such as the personal networks that directors bring and their relationships with existing board members, may also influence appointments (Stevenson \& Radin, 2009).

\subsection{Summary}

Overall there is a trend for boards to be more independent from both management and shareholders. In most companies management is now represented by a single director, the CEO, and a full $75 \%$ of NZSX boards are controlled by independent directors. Shareholder influence is also limited because in many companies shareholdings are fragmented, and institutions that are usually among the largest shareholders are reluctant to get involved in day-to-day governance matters (Chui \& Monin, 2003). So overall many companies are operating in an environment where the traditional influence of shareholders and management, two of the key stakeholder groups, has declined. Boards therefore are less accountable and have the potential to become self-perpetuating in that board members 
frequently appoint their successors, a trend that has been observed elsewhere (Berle \& Means, 1932; Cadbury, 2002, p. 68). While this trend may benefit the company in terms of maintaining company values (see 5.1.1), it also has some disadvantages, as the board can become disconnected from the realities of the business (NYX, 2010).

Boards are also tending towards the best practice guidelines proposed by the OECD (2004) and the Securities Commission (2011), among others. However, it is important to note that these changes in and of themselves do not imply any particular shift in behaviour from boards. For example, there is an expectation that the chairman will oversee the process of hiring, firing, evaluating, and compensating the CEO (Jensen, 1993). Quite how effective an independent chairman would be in performing this function on a board that includes, say, the company's founder or principle shareholder is a matter for conjecture. In addition there is no conclusive evidence to suggest that these factors influence overall company performance (Leblanc, 2004). Nonetheless, from the perspective of this research the findings are important as they are issues that can influence both shareholders' and directors' perceptions of boards. 


\section{PRELIMINARY FOCUS GROUP RESEARCH}

Before commencing detailed field research two small focus group exercises were conducted. Their objective was twofold: first, to ensure that the subsequent research focused on the appropriate issues; and second, to ensure that the subsequent research initiatives were best positioned in terms of the topics covered, the language used and the depth to which issues were probed. Because only two focus groups were conducted and because of the exploratory nature of this phase of the research, insufficient data was collected from which to extrapolate the findings to the broader NZX governance environment, nonetheless the two focus groups are sufficient to meet the objectives specified and to provide the contextualised insights required at this phase of the research.

\subsection{Focus Group Demographics}

Table 27 summarises the demographics of the two focus group participants.

\section{Table 27}

Focus group demographics

$\begin{array}{lccll} & \text { Participants } & \text { Gender } & \text { Experience } & \text { Comments } \\ \begin{array}{l}\text { Director } \\ \text { Focus Group }\end{array} & 5 & \text { All male } & \text { All 25 years }+ & \begin{array}{l}\text { All directors have board experience with multiple } \\ \text { NZX-listed companies and } 4 \text { have chaired NZX10 } \\ \text { companies }\end{array} \\ \begin{array}{l}\text { Shareholder } \\ \text { Focus Group }\end{array} & 6 & \begin{array}{l}4 \times \text { male } \\ 2 \times \text { female }\end{array} & 5-35 \text { years } & \begin{array}{l}\text { The experience of the group ranged from new to } \\ \text { the market and making small investments to very } \\ \text { experienced and using their investments as their } \\ \text { prime source of income. }\end{array}\end{array}$

As discussed in section 3.5.2, an objective for the director focus group was to invite directors who were exceptionally well experienced and who were approaching the end of their careers to participate. It was considered that such directors would be more inclined to discuss issues candidly 
than their more junior colleagues. This objective was met, as the directors who participated had all directed or chaired some of New Zealand's largest firms including banks, insurance companies, property companies, and an airline. An objective of the shareholder focus group was to invite shareholders with a broad range of experience. The shareholder focus group consisted of six members, five of whom were experienced shareholders with 20 or more years of experience in investing in NZX-listed companies. The sixth member had invested in NZX companies for five years. One focus group member was also a member of the Shareholders' Association board and another was a high net worth individual, who stated that his primary source of income was his NZX share investments. Two of the focus group members were women. The focus group therefore achieved its demographic objective of drawing on investors with a diverse range of skills and experience that are broadly representative of the wider private investor population and that approximated the shareholder segments identified by ASX (2011) as discussed in 4.4.1. Both focus groups were conducted in a relaxed environment over lunch in July and August 2014. The following sections discuss the findings from each of the focus group.

\subsection{Director Focus Group}

Directors are generally reluctant to discuss the details of boardroom activity (Leblanc \& Schwartz, 2007), and so it proved with these focus group interviews. The interviewer quickly established rapport with the interviewees and the focus group was conducted in a congenial atmosphere with no shortage of discussion. However, the researcher found that maintaining control over the discussion and getting direct answers to probing questions proved challenging. This was attributed to the experience of the interviewees, who all proved to be adept at politely steering conversation away from potentially controversial subjects. The result was that although the three hours of interview and discussion provided less formal data than had been anticipated, some interesting and important 
themes that I had not previously been considered were identified. Most significant amongst these themes was the importance and influence of government shareholders.

One of the key themes that underpinned all of the discussion was that the fundamental approach to governance varies between companies and this makes it difficult to generalise about many aspects of corporate governance. For example. when considering the role of governance one director stated 'there is a difference between companies that are $51 \%$ [owned] by one shareholder, and other companies' (Director 1). When considering the role of shareholders another director considered that, 'I have in my head the desire to treat all shareholders equally and I strictly adhere to that, but there are times when that changes, like in capital raisings' (Director 2). Approaches to governance practices also vary as the following two examples illustrate: when considering board self-assessment one director noted; 'the models that you can see, some have a lot of variation in them, some have peer assessment ... but a lot of boards hate it with a passion' (Director 3), and on reporting, another director stated; 'reporting is quite variable and it's difficult to say that an average company reports well or not' (Director 4). These differences, in both the approach to governance and governance practices between companies, are consistent with the views of Huse and others who found similar variations, which they attribute to the impact of environmental factors (Huse, 2005; Aguilera \& Jackson, 2003).

The focus group discussion was based around three major themes: the role of the board, the relationship of the board with shareholders, and the directors' views on director qualifications and attributes.

\subsubsection{Role of the board}

There was agreement between all focus group members that the role of the board is primarily to focus on activities that advance the long-term interests of the company. The directors were of the 
opinion that, to a large extent, they were the only group who had the long-term interests of the company at heart, given that management and most shareholders have short-term objectives. The following quote summarises their views on management:

'Executive staff are interested only in the short term and the board will decide best practice for the company long term' (Director 3).

The directors were of the opinion that analysts from institutional investors encourage this thinking in management.

'There is too much reporting going on and it interferes with shareholder relationships and executive pay; [too much] "short-term-ism" - they all want a good quarterly result and it may be terribly against the interest of the company,' opined Director 4.

Another said that 'shareholders and the analysts changed executive behaviours and that's what led to the GFC' (Director 1). Maintaining this long-term perspective, the directors noted, brought them into conflict with both management and shareholders from time to time.

'Management, my colleagues, they pay homage to analysts, try to get them to talk about other things, they come back to analysts all the time,' said Director 1.

And from director 3:

'At an AGM a hand goes up and says, "Can't you increase dividends?” And that places you in a difficult position when you have a $51 \%$ shareholder looking for growth who is prepared to forgo short-term dividends' (Director 3).

As with most other points raised there was an acknowledgement that the role and priorities of a board can change from company to company and that over time, as the following quote 
illustrates, 'shareholders are important, but they may, at some stages, be a bit less important than customers' (Director 1).

The focus group directors made statements that supported a stakeholder theory rather than shareholder theory approach to governance as the following example illustrates:

'Treat your staff and customers as shareholders. If you only go after shareholder value it will wreck the company' (Director 2).

The directors all acknowledged that not all New Zealand company directors shared their views, and they each cited some examples of boards that were seen to have adopted a shareholdercentric approach to governance. A strongly shareholder-centric approach to governance, the directors all agreed, often resulted increasing the short-term share price, albeit potentially at the cost of the underlying long-term value of the firm.

The directors interviewed all consider that the role of the board includes setting and upholding the companies' values, a function they consider to be absolutely fundamental to the longterm success of the company, as the following quote illustrates:

'A company that values the brand and staff can actually make it, they are a company' (Director 2);

and from another director:

'The thing about values is you never, ever get offside with a customer, you treat them like one of the family, so suddenly you get productivity, you get people wanting to work for you, and it's interesting.' (Director 3).

Recent examples of finance company failures and product recalls were cited as examples of boards and companies failing to adhere to their core values. This emphasis on the role of the board 
in establishing the company culture is a feature of governance that is not identified as a primary responsibility of the board in any of the definitions summarised in Table 2 (p. 30).

The financial metric that most directors considered to be the key measure of company progress and success was a progressive increase in dividend, rather than increases in share price or any accounting metric. However, this view was not universally accepted by all directors. As one said,

'If you haven't got the cash to start with you certainly don't want to start borrowing to pay dividends, so I don't see that it comes down to those sort of discrete measures' (Director 1)

However, as none of the directors advocated using either traditional accounting measures or share price as yardsticks to measure company success their comments support the arguments outlined in section 2.5.1, i.e. that there is a disconnect between the measures that boards and academics use to measure company performance.

\subsubsection{The relationship of the board with shareholders}

The directors interviewed do not consider shareholders to be owners of the company in anything other than a legal or abstract way, as the following discussion shows:

'Well are they [shareholders] owners? This is a big debate.' (Director 4)

'Well, legally they own the shares - that's a philosophical answer.' (Director 1)

'Thinking about who owns a company doesn't get us very far.' (Director 1)

From a practical perspective the directors considered shareholders to be one of a number of stakeholder groups who, along with customers, employees, and debt funders, have certain rights and obligations that need to be satisfied while the board pursues its ultimate goal of maintaining the best interests of the company. The Director focus group participants' perspective is therefore very much 
in line with the objectives of the 1993 Companies Act. There was, however, an acknowledgement that the relationship between shareholders and the board is dynamic, and that it changes over time depending on factors such as the environment that a company is facing and the blend of shareholders and debt providers. For example, when considering technology start-up companies, which are characterised by high growth and high risk, one director suggested that 'shareholders should simply be considered unsecured creditors' (Director 2). Another director, however, was less dismissive of shareholders in these companies, arguing 'priorities may shift from time to time, but I reckon the shareholders are important'.

It was apparent from the discussion that the directors interviewed do not consider all shareholders to be equal, and that they notionally segment shareholders into separate groups and adopt different strategies for interacting with each group. The groups identified were private or retail shareholders, institutional shareholders, government, and majority shareholders. There was universal agreement that on occasion the different segments will have different goals and objectives creating challenges for boards. This is amply illustrated by the earlier quote about shareholders petitioning for an increase in dividends; and, in a discussion about a company where the government holds the majority of the shares: 'The retail shareholders, they really don't count in the big scheme of things; you might think that they do but they don't act on the information they are getting. The AGMs seem to be farcical, because [the shareholders] come along and don't ask that many penetrative questions' (Director 4).

Capital raising is an activity where the focus group directors believe boards sometimes treat shareholders differently - mainly by giving preference to large or institutional shareholders. Favouring large shareholders in these circumstance was seen as expedient, but the practice did not meet with the full approval of the focus group members, mainly because of the potential to damage other shareholder relationships. To quote one director, 
'One classic was Singapore Airlines holding in Air New Zealand; historically, that's quite a good case study where a particular shareholder demanded a better deal than the others were going to get, and that led to a lot of unease and distrust and the culture of the company really suffered as a consequence' (Director 3).

Another director commented:

'A company that I chaired had a deeply discounted offering to our shareholders and ninety per cent was taken up, the ten per cent was taken by the broker, who then exposed those shares, which affected the market, and I . . . feel unhappy about it. Directors get influenced by easy money and maybe don't keep shareholders at the top of their minds' (Director 1).

\subsubsection{Qualifications and attributes of directors}

The directors who participated in the focus group all had firm opinions regarding the overall composition of the board and the skills and attributes that individual directors require. When considering overall board composition, issues such as loyalty to the company, professionalism and an understanding of the legal obligations of a director were simply 'taken as read' and did not warrant discussion. The element that was considered most worthy of discussion was diversity of thinking and approach. To quote one director,

'The whole reason for having a board is to get a wide range of perspectives and then to get a collective view. If you didn't need a collective view then you would only need one person' (Director 1).

A potential diversity of views was seen as an important feature of modern boards. To provoke a debate regarding diversity I proffered a provocative statement: 'the best people to appoint new directors are the existing directors?' This elicited the following responses: 
'I disagree.' (Director 1)

'I disagree.' (Director 3)

'I don't agree. I don't think that's what it takes to get diversity, and diversity is something boards need; you don't want everyone looking the same, or being from an accounting background ...' (Director 2)

'Go to a reputable searcher and give them the criteria and then get a whole lot of sensible recommendations. Instead of saying - oh gosh, he is a nice chap.'

(Director 1)

This suggests that these directors consider diversity to be a key attribute of boards and that they are prepared to recruit outside of their immediate social circles in order to obtain this diversity.

The second most important consideration was ensuring that directors actively participated in all board activities. To quote one director, 'People that don't contribute are an absolute nightmare' (Director 1). The focus group directors had all sat on boards with directors who would only participate in discussions related to their specialist subject and all of them expressed their frustration with such directors. As one director stated,

'That's why I emphasise diversity; I mean, if you want an expert on something, you hire them' (Director 1).

However, there wasn't a complete consensus, as the following interchange illustrates. 'I find ex-CEOs the worst ... they want to report on everything - a report on that and a report on the other thing, just taking up bloody time, and they want to manage the company.' (Director 2)

'That's right, but by the same token, having been a CEO is, I think a really helpful piece of background in some of this work - well, a lot of this work.' (Director 1) 
When considering the personal attributes of directors, emphasis was placed on general skills, such as being a team player, having proven experience and general commercial acumen, rather than on specific professional skills. It was also agreed that directors need to engage with the businesses they are governing and to understand them in some detail, something that they felt was lacking with many New Zealand directors. To quote one interviewee,

'I am a firm believer that with directors they need to understand the business, they can't just turn up every month and sit in a helicopter unless they know what the business is all about' (Director 4).

It was agreed by all the directors that specialist directors who did not have these broad 'commercial' skills did not benefit boards. As one director stated, 'If you need specialist expertise you can hire it for the job in hand' (Director 1). And from another director:

'If you are stuck with a director who is a lawyer or accountant they feel obliged to use their expert knowledge and that goes against them contributing a wider perspective' (Director 4).

The directors interviewed were acutely aware of their personal reputations and the value that these reputations bring to the companies they are associated with. Given that two of the participants had knighthoods, this is perhaps unsurprising; nonetheless all of the participants were of the opinion that the personal reputation of directors is one of the strongest influences in shaping director behaviour. In response to the interviewer's question 'What makes directors care about the companies they govern given that the financial incentives aren't significant?' one director replied: 'All directors value their reputation, and that's where the care naturally comes in' (Director 1). 


\subsection{Shareholder Focus Group}

The shareholder focus group session was divided into two parts: the first consisted of a series of prepared questions which were delivered in a semi-structured manner, and the second involved an open discussion across a wide range of governance issues. The key topics discussed were: the importance of the board to shareholders, the relationship between the board and shareholders, and the qualifications and attributes of board members. It was apparent from early on in the focus group that some of the members had quite different expectations of boards, as can be inferred from some of the quotes following.

\subsubsection{The importance of the board to shareholders}

The focus group members were asked how important they considered the board to be, and to what degree the board featured in their decision to invest in particular companies. When making investment decisions none of the focus group members placed governance or anything related to the board in their top three criteria. While there were differences of opinion between focus group members over the criteria they use to select companies to invest in, there was unanimous agreement that management, financial strength, product and brand were all more important than the quality of the board. In fact for several focus group members the board did not feature at all in their investment criteria. As one said:

'I'm thinking about a board for the first time, which is kind of embarrassing because I've been investing in public companies for twenty years or more' (Shareholder 1).

Another focus group member was equally dismissive of boards:

'They are not really driving the company and they are not working for the company, they are almost peripheral' (Shareholder 4). 
Others were, however, more aware of boards and their function:

'I want to know whether the board just meets once a month or once a quarter. I am quite interested in whether they have subcommittees and I am also quite interested in what the backgrounds are of the board members and whether their various relationships can be used to leverage the company that they are a board member of' (Shareholder 3).

\subsubsection{The shareholder-board relationship}

The relationship that shareholders have with companies and their boards was explored. The focus group members approached the relationships that they have with the companies they hold shares in from the perspectives of either company owners, passive investors or speculators. The following quote is indicative of those shareholders who consider themselves company owners:

'I will email a company and say, I like the way you do such and such' (Shareholder 3),

and the following is indicative of those who consider themselves passive investors;

'I have no influence in a large company I buy shares in, so I can't see myself as an owner; I see myself as an investor who is free to come and go. If I am an owner I am not free to come and go and that is a different mind-set' (Shareholder 4).

While the focus group members acknowledged that they primarily considered themselves to be either owners or passive investors, they also acknowledged that from time to time they also consider themselves to be speculators;

'She made quite a lot of money on these ... shares [but] didn't even know what the name of the company was, [she was] just doing day trading' (Shareholder 4). 
There was acknowledgement that shareholders sometimes change their strategy from company to company - for example, a shareholder may consider themselves as an owner of one company but as a speculator in another - and it is possible their expectations of company boards may change as a result.

None of the shareholders interviewed appeared to have a clear expectations regarding the role of the board is, as the following quotes illustrate.

'The expectation is that the directors must work in the interests of company; it's just a conflict of interest that shareholders can hire and fire them' (Shareholder 5).

'They have a sort of oversight role and I can imagine it being almost peripheral to the company because how you really control a company is by [appointing] somebody to run the company' (Shareholder 3).

'I want to think that your board are thinking into the future and I am not convinced that they are' (Shareholder 6).

'Do you actually need a board? Never actually having thought much about them . . I was thinking ... are they just a sort of a thing that exists through some kind of inertia and that you have to have a board but they don't actually do very much, and how about we just get rid of boards?' (Shareholder 1) 
The focus group members' responses show that they do not consider the board to be a core function essential to the operation of the company. For example, they did not raise the issue of the role of the board in strategy formation; their consensus was that the CEO and management 'drive' the company, as the following quotes illustrate:

'The value creation side is in management'(Shareholder 4).

'Management of the company matters, in my mind; I don't actually pay a lot of attention to the board' (Shareholder 2).

'These directors, they get their $\$ 50,000$ for attending a few meetings, they're not really driving the company, and they are not working for the company' (Shareholder 3).

The role of the board in capital raising led to a debate regarding the role of directors in the recent finance company failures. The focus group members all attributed these finance company failures to failure of governance rather than of management:

'With the finance companies, the directors ... forgot that they actually represented investors - they went off into their own little bubble (Shareholder 1).'

was a typical comment. It was apparent from the discussion that the focus group shareholders consider that the success of the company can be attributed to the CEO and the management team, but any failure is the responsibility of the board. This view is consistent with that of the directors interviewed, one of whom stated,

'Shareholders don't worry about boards until something goes wrong and then when it does [go wrong] these days they look to the board to blame and to sue' (Director 1). 


\subsubsection{Qualifications and attributes of directors}

When considering the qualifications and attributes of directors, focus group members placed importance on the public profile of the directors, the number of boards they sit on, gender diversity, and the depth of their personal networks. Academic and professional qualifications were not discussed.

Opinions were divided regarding the value that high profile directors bring to boards, as these quotes illustrate:

'Follow the investors [i.e. directors] is absolutely valid; if you want to coat-tail on what he is doing then that is fine.' (Shareholder 4).

NZ [is] such a small country, you can select the people that you have something against but I, I generally don't, it's not a criterion for me, I am more of a quantitative analysis person.'(Shareholder 5).

'I think there [are a few] old school people running around and the way that people do business has moved; a lot of these people are still stuck in the eighties and the nineties' (Shareholder 6).

There was similar disagreement over the merits of directors sitting on multiple boards. Some argued that this was beneficial in that 'New Zealand is a small country and we need to spread it around', and others argued that those directors who sit on multiple boards spread themselves too thinly:

'There are some people like [name], who is on every single board, and . . I have said, well I am not buying that because how can you possibly be on the board of twenty different companies?' (Shareholder 3) 
Diversity was considered an important issue. However, for most of the focus group members the term appeared to be shorthand for 'gender diversity', as this was the only form of diversity discussed.

'The arguments used for women on the boards is they have such different networks and such a different way of looking at things that you actually bring something very different to the board, which may at times be unpleasant because it makes you think in another way’ (Shareholder 5).

'If you read all the research that has been done about [women on boards], the benefit is much better-performing boards. And it was something like $11 \%$ - it was definitely significant, and ... measured by dollars and cents' (Shareholder 3)

During this conversation, body language changed (arms were crossed) and the tone of conversation became more formal. It quickly became apparent that this was a controversial and divisive subject that generated a strong emotional response from some focus group members, so the topic was dropped.

The value of directors' personal networks were considered, with some focus group members seeing these as a potential source of business and a competitive advantage for the company. Others were less confident, believing that directors simply networked between themselves and were not especially 'in touch' with customers or suppliers. The following quotes are indicative of the views expressed:

'Networks are quite important often in business and I think a board can play a role in facilitating business' (Shareholder 6).

'Using networks is pertinent and it's one of the things that I would hope that the board would bring to the table, individual directors would bring to the table' (Shareholder 4). 
'These directors all belong to a similar network, not lots of networks,' (Shareholder 6).

'At the annual meeting last year we were saying goodbye to the other director and he said they lived next door to each other, well come on, where is the breadth of networks?' (Shareholder 3).

Independence was not an attribute that was specifically raised by any of the focus group members. They did, however, categorise directors as either good or bad, and the following quote went unchallenged: 'the media, show us the baddies but the baddies we know, people like [name] did not read his papers [and so] he shouldn't be a director.'

Some of the focus group members were concerned about the role of institutional investors, who they viewed as breaking the communication between boards and shareholders, to the detriment of individual shareholders. The following quote sums up the sentiment:

'There is a cold hand going through the market over the last couple of decades, it's because we have seen the growth of the institutional investor. If you step through a fund manager and then you step down to someone who is invested in funds, you have got a breakage in the line of communication.'(Shareholder 4).

Not all focus group members shared this view and some stated that they had not previously considered the role of institutional investors in the market.

\subsection{Summary}

The focus group research achieved its objective of identifying key issues that likely influence directors and shareholders expectations of governance and providing direction for the positioning of the subsequent research. Specifically the research provides an indication of: the overall understanding that experienced shareholders and directors have of corporate governance, how they 
approach the subject, the issues that they consider to be most important and topical, and the areas where differences in expectations may exist between shareholders and directors.

The results further suggest that directors and shareholders have quite different opinions on the role of corporate governance in general and they also appear to have different expectations of both boards and directors. The directors interviewed all considered that their role involves focusing on strategic issues and ensuring the long-term positioning of the company, and is central to its overall success. These views are broadly consistent with previous NZ research in this area (Northcott \& Smith, 2011; Ingley \& Van der Walt, 2005). The shareholder focus group members, on the other hand, all consider that boards are largely peripheral to the success of the company and that their role is primarily to ensure that the CEO and management stay on target. Both groups agree that in the event of a corporate failure board members will be called to account.

The directors interviewed exhibited views and opinions that were broadly consistent with a stakeholder-centric approach to governance. For example, they were unequivocal in their view that the role of the board was primarily to look after the interests of the company (and by implication all stakeholders) rather than just the interests of shareholders, although they also acknowledged that not all NZ directors share their views. The shareholders were less definitive in their views and opinions, and appeared to fluctuate between holding a shareholder-centric view of governance and a stakeholder-centric view depending on the issue being discussed. While most of the shareholders stated that they believed the primary role of the board was to represent shareholders, there was also a pragmatic acceptance that this did not always occur and that on occasion directors prioritised the needs of other parties (such as their own).

There was no discussion in either focus group which suggested a real or implied principle/agent arrangement between shareholders and directors that is required as a prerequisite for the application of agency theory. For example, the shareholders' relationship with boards was 
portrayed as largely passive and reactive, which is not consistent with the behaviours expected of a principal in a principal-agent relationship. Rather than considering the board to be their agent, shareholders for the most part appeared to view it as though it is an appendage to the body of the company with a somewhat unclear role. This perspective does not appear to easily reconcile with any of the governance theories outlined in section 2.3 .

Both directors and shareholders hold clear views on who should be appointed to boards. Given the different relationships that directors and shareholders have with boards, it was to be expected that the two groups would value different attributes, and this proved to be the case. Directors, who must work with each other, understandably value attributes such as teamwork and individual participation, and because most board activity is not visible to shareholders these are not attributes that shareholders would naturally consider. For their part, shareholders focused on the public profile of directors and the issue of diversity within the board. Diversity is in fact an important consideration for both shareholders and directors. The directors defined it as 'diversity of thought' and considered this to be an important attribute that could be achieved by appointing directors from differing backgrounds and different experience outside the existing directors' social circles. The shareholders interviewed were more inclined to consider diversity from a purely gender perspective.

The directors interviewed acknowledged that they treat some groups of shareholders differently, large shareholders can receive preferential treatment over small shareholders in capital raisings for example. Directors and some shareholders appeared to be concerned about the role of institutional shareholders and their potential influence on companies which may lead to this group of shareholders receiving different treatment from boards. The directors were concerned, too, about the influence of analysts; in particular they felt analysts encouraged management to focus on shortterm objectives and the company share prices, possibly to the long-term detriment of the company. 
Some shareholders were concerned that institutional investors acted as a barrier between shareholders and the companies in which they were investing. 


\section{ANALYSIS OF ANNUAL SHAREHOLDERS' MEETING MINUTES}

Once a year directors are required by law to hold an annual shareholder meeting (ASM) to discuss the affairs of the company (Companies Act 1993, section 120). It is the only time the board is legally obliged to meet shareholders. These meetings have been a feature of public companies since their inception (Joint Stock Companies Act Schedule A, 1844). At ASMs directors are appointed, annual reports are tabled and directors are authorised to appoint auditors and set their remuneration. The meetings are also used by the board to report to shareholders on the company's performance, outline their future plans and gain approval from shareholders on various matters. For most shareholders these meetings are also the only opportunity they have to directly engage with their board. Because shareholders are the only stakeholder group with a legal right to participate in ASMs, they are therefore the only group with a guaranteed opportunity to express its views directly to the board. This places them in a unique position relative to other stakeholders as it is likely that the feedback that the board receives at these meetings can somewhat influence director behaviour.

Analysing the minutes of these meetings, and in particular the questions raised by shareholders, therefore provides unique insights into not only the concerns and motivations of shareholders but also the relationship between the board and shareholders. While the analysis of company annual reports has been previously conducted (Ahmed \& Courtis, 1999), to the best of the author's knowledge no analysis of ASM minutes has previously been published in New Zealand. Although the meetings themselves are for the most part public and it is not uncommon for the press and members of the Shareholders' Association to be in attendance, some companies were very reluctant to disclose their minutes. This is entirely within their rights, as there is no legal obligation for companies to disclose the minutes of these meetings to anyone other than shareholders. However, given that the NZX's continuous disclosure requirements obligate companies to disclose anything of a material nature (NZX, 2013, section 10), the minutes themselves cannot contain 
confidential information that is material to the company share price, so it is difficult to understand the desire to keep these minutes confidential.

\subsection{Responses}

As discussed in 3.5.3 a written request was sent to the company secretaries of all 112 listed companies for copies of the minutes from their last three ASMs. While a few companies publish their ASM minutes on their websites many companies would only release their minutes after a lengthy dialogue over precisely how the information would be used and after verifying the researcher's credentials. Even after these discussions five companies simply refused to release their minutes. Table 28 summarises company responses.

\section{Table 28}

Summary of responses to ASM minutes survey

\begin{tabular}{lrr} 
& Companies & Share \\
\hline Provided minutes & 30 & $27 \%$ \\
Declined to participate & 5 & $4 \%$ \\
No response received & 77 & $69 \%$ \\
Total & 112 & $100 \%$
\end{tabular}

To determine if the companies who provided their minutes were indicative of the overall market some comparisons were made between the companies who responded and a reference sample of 30 companies that was selected from the companies discussed in section 3.4.2. Table 29 summarises the attributes that were compared and the results of this comparison. 


\section{Table 29}

ASM minutes survey respondents compared to a reference sample of companies

\begin{tabular}{crrr} 
& $\begin{array}{c}\text { Survey } \\
\text { respondents }\end{array}$ & $\begin{array}{r}\text { Reference } \\
\text { sample }\end{array}$ & T-test (p) \\
\hline $\begin{array}{c}\text { Board size } \\
\text { Number of respondents }\end{array}$ & 30 & 112 & \\
Average board size & 6.0 & 6.6 & 1.718 \\
Number of shareholders & & & \\
Number of respondents & 29 & 40 & \\
Average shareholders & 14,768 & 10,971 & 0.157 \\
Market capitalisation & & & \\
Number of respondents & 30 & 112 & \\
Average market cap. & $\$ 277 \mathrm{M}$ & $\$ 229 \mathrm{M}$ & $1.533^{8}$ \\
Size of largest shareholding & & & \\
$<10 \%$ & 8 & 10 & 0.875 \\
$>10 \%$, & 13 & 17 & 0.944 \\
$<20 \%$ & 10 & 13 & 0.824 \\
$>20 \%$ & & &
\end{tabular}

This table shows that no statistically significant differences exist (at a 5\% threshold) between the survey respondents and those of the reference sample with respect to the size of their company boards, their market capitalisation and the size of their largest shareholder; this suggests that the data received from the respondents is likely to be indicative of the market as a whole.

From these minutes, details of the results of the votes cast and questions asked by shareholders have been analysed. Voting has been summarised by the originator of the resolution (shareholder or board), the outcome (successful or unsuccessful) and, in the cases where the details

\footnotetext{
${ }^{8}$ Note: Market capitalisation data has been normalised using a natural logarithmic scale.
} 
of the votes cast were published, the percentage of votes for and against. Questions asked by shareholders have been grouped by topic and summarised.

The 30 companies that responded contributed a total of 65 sets of minutes for meetings held between 2010 and 2013.

Based on the shareholder attendance figures published in the ASM minutes, attendance levels at the ASMs analysed was less than $4 \%$ of the total shareholders. Given that the average shareholding is valued at approximately \$5,300 (4.3.1), this finding supports Berle and Means' (1932) observations regarding the rational of shareholder apathy: it may not be an effective use of shareholders' time to attend such meetings.

\subsection{Resolutions Tabled at ASMs}

A summary of the resolutions proposed at these 65 ASMs shows that:

- All resolutions proposed by the board were passed. Voting was either by a show of hands or by a poll. Where a poll was called, all board-proposed resolutions were passed with a majority of at least $86 \%$ of the votes cast.

- All resolutions proposed by shareholders failed. There were just four resolutions proposed by shareholders and all four were for the nomination of directors.

- All directors nominated by the board were appointed. In most cases these directors were elected by a simple show of hands. In 18 cases, however, a poll was conducted and the results published; in these cases the directors were typically elected with a majority in excess of $99 \%$, with the lowest majority being $96.2 \%$. 
- Share options or other equity incentive schemes for CEOs are the most controversial resolutions. Although all such resolutions put at these ASMs were passed, when polls were taken and the results published, the votes in favour dropped to as low as $86 \%$.

- Resolutions concerning the appointment of auditors and setting their remuneration were always approved and there was no instance of an auditor being challenged or their reappointment.

These findings show that directors are firmly in control of the proceedings, given that, regardless of the discussion, their position on issues was always adopted. This suggests that shareholders who strongly dissent may simply sell their shares and exit the company ahead of ASMs as suggested by Thompson, Edelman \& Paul ( 2009) .

\subsection{Shareholder Questions}

The questions raised by shareholders at ASMs and recorded in the minutes were analysed to identify common themes and issues. The level of detail recorded in the minutes varied considerably from company to company. Five companies (who collectively contributed 10 sets of minutes) have adopted a practice of not recording shareholders' questions in their minutes. This practice is acceptable as neither the Companies Act nor the NZX has any specific requirements regarding the level of detail that should be recorded in the minutes. Furthermore, there is no record in any of the minutes of any shareholder challenging this practice, so it seems likely that both directors and shareholders accept it. A review of those companies did not find any common theme either within their annual reports or in the media that would explain such a practice, so it may simply be company policy or a practice that has become established over time. At a further five ASMs no questions were raised - again for no obvious reason. 
Research on ASMs is sparse (Catasús \& Johed, 2007) and the author is unaware of any other research that has analysed questions asked at ASMs so it was necessary to develop a classification scheme. This was achieved by multiple readings of the minutes and determining logical categories from the content itself. Full readings of the minutes were necessary because the context in which questions were asked sometimes influenced the category to which the questions were assigned. The 50 sets of minutes where shareholders' questions were recorded contained a total of 309 questions. Once analysed the questions were grouped into twelve categories. Figure 9 summarises these results.

\section{Figure 9}

Summary of questions asked at ASMs

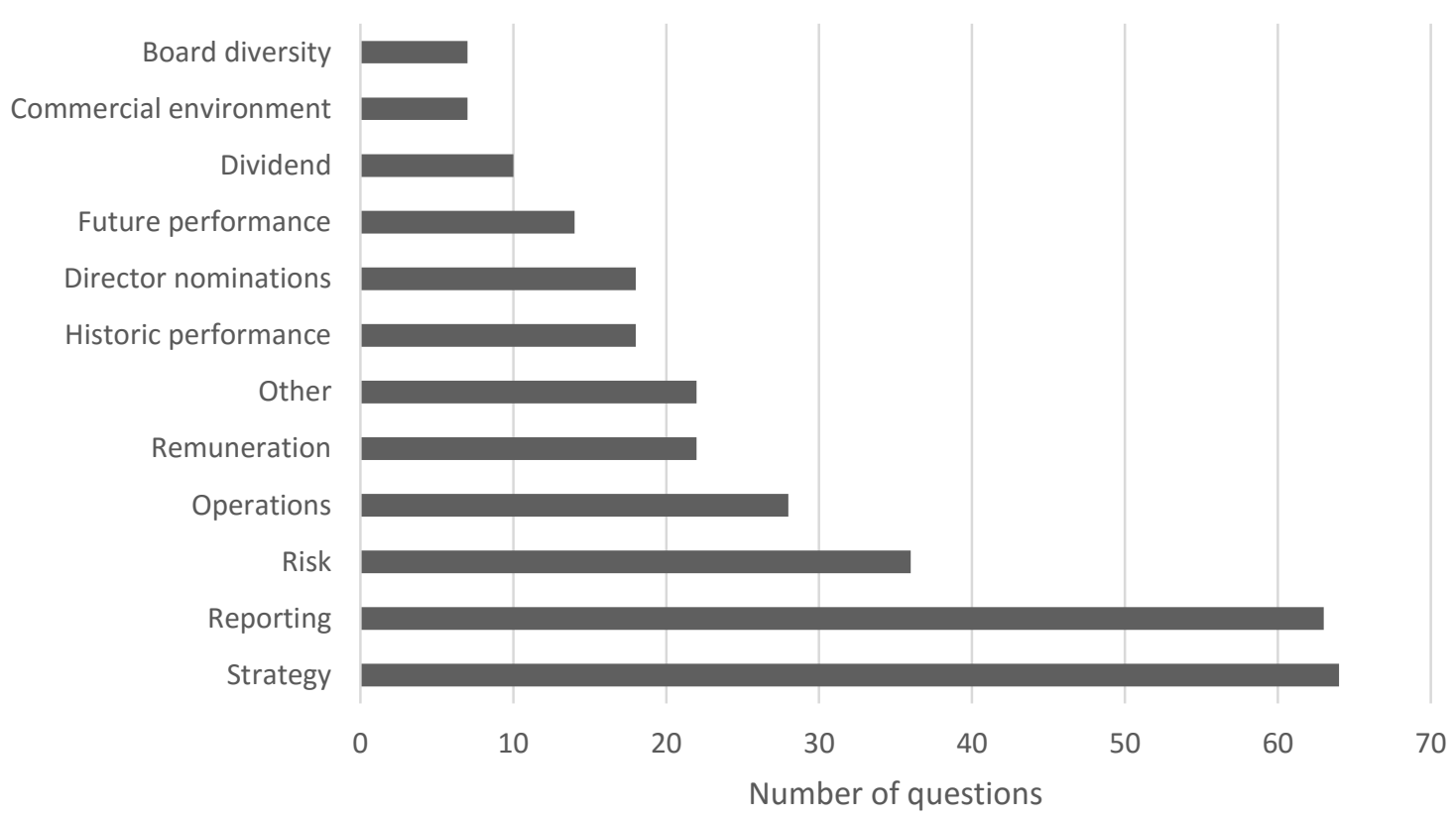

A definition of each of the categories follows:

1. Strategy: questions relating to the companies' underlying business model and potential changes to it. Questions about potential acquisitions and divestments and the degree of focus on the core business operations are included in this category. 
2. Reporting: questions arising from information presented in the annual report or other company communications. The majority of these questions concerned clarifying information presented in the financial section of the annual reports.

3. Risk: factors external to the company that may affect future earnings, such as earthquakes or exchange rate variations. Many of these questions were centred on earthquake preparedness.

4. Operations: any issues around the day-to-day performance and operation of the company, including production, sales, marketing and quality. Some of these questions were couched in financial terms, such as 'why are admin expenses rising faster than sales?', while other questions focused on a specific aspect of the business, such as 'what is the real benefit of the new logo?'

5. Historic performance: these were questions requiring explanations for the company's overall historic performance or explanations for specific actions that the company has taken. Common themes included shareholders requesting an explanation for a decline in their company's share price, and questions surrounding the performance of specific assets or individual business units.

6. Commercial environment: the general economic environment and the overall performance of the industry sector and markets in which the company operates.

7. Director nominations: questions relating to the backgrounds of board nominees, and questions around the director nomination process. 
8. Remuneration: these questions focused on director, $\mathrm{CEO}$ and senior executive remuneration; no questions were asked relating to general employee remuneration levels. Shareholders appear very keen to link director and executive remuneration to either share performance or overall company performance, and when a company's performance was poor, shareholders frequently raised objections to proposed increases in directors' fees. Shareholders also frequently questioned payments made to directors other than their standard director's fees.

9. Board diversity: these questions related to the appointment of women to either the board or senior executive positions.

10. Future performance: these questions related to the expected future performance of the company or the share price.

11. Dividend: questions around either the sustainability of the current dividend policy or the likelihood that the dividend will be increased.

12. Other: this category covers miscellaneous questions on a wide range of topics, including meeting process issues, the intentions of other shareholders, and oddities such as 'should we erect a memorial to Sir Keith Park?'

\subsection{Summary}

ASMs are intended to have three principal functions, informing shareholders about financial performance, gaining consent for certain decisions outside of management discretion and acting as a forum for discussion between shareholders and the board (Strätling, 2003). The analysis of these 
minutes suggests that most ASMs, superficially at least, meet these objectives. However the low shareholder participation and the lack of probing questions asked at these meetings also point to the ritual nature of these meetings that has been noted by Catasús and Johed (2006) and others.

The minutes show that boards are firmly in control and that directors consider it their responsibility to inform shareholders rather than seek direction from them; shareholders, for their part, are generally content. That the board is firmly in control is reinforced by the finding that all resolutions proposed by the board were passed with substantial majorities, and the question analysis, which showed that very few hostile questions were raised at any meeting - even at the meetings of companies that were underperforming and were probably not meeting most shareholders' expectations. The overall impression of contentment among shareholders may be attributed to two factors. Firstly, small investors who are unhappy with the performance of either the company or the directors may have simply followed the 'Wall Street rule' (Thompson, Edelman \& Paul, 2009) and sold their shares ahead of the ASM; and secondly, an accord on any controversial issues is most likely reached between the board and major shareholders before the meeting agenda is set (Chiu \& Monin, 2003; Strätling 2003). These agreements are probably made because it is not in the interests of major shareholders or directors for influential shareholders to express negative opinions regarding the company in public. Such comments have the potential to adversely affect the share price.

A close relationship between major shareholders and the board can also be inferred from the director nomination process. In the minutes of the meetings analysed, all of the non-executive inside directors nominated by boards were appointed. These directors, by definition, have an association with a substantial shareholder, so it is reasonable to conclude that some dialogue occurred between these shareholders and the board before the nominations were made. Independent directors nominated by the board were also appointed, and conversely all shareholder-nominated directors were rejected. This suggests that boards have a strong influence over the appointment process and 
lends support to the observation that boards can become self-perpetuating, in that existing directors appoint their successors (Cadbury, 2002).

What is also apparent from these minutes is that there is no evidence to suggest that shareholders are interested in anything other than the financial aspects of their investment. For example, no questions were asked regarding issues such as corporate social responsibility, company environmental policies, employee welfare, the company's role in the wider community, or triple bottom lines - topics which all feature in the corporate governance literature. Whether this is truly indicative of shareholder sentiment is open to conjecture, as it is possible that given the limited time available for questions and the formality of the proceedings shareholders may feel obliged to restrict their questions to issues related to the economic performance of the company.

The area that is most likely to generate negative comments from shareholders is executive and director remuneration and incentive payments, even though in most cases the dollar amounts involved were quite small relative to the profits generated by the companies concerned. The following quote recorded in a company's ASM minutes is indicative of shareholder sentiment '[name $]$ stated that he supported the resolution and looked forward to an increase in dividends of the same proportion as the increase in directors' fees.' Although resolutions regarding remuneration were all passed, in the cases where polls were taken the majorities were always lower than for any of the other resolutions passed.

For the most part the questions raised by shareholders appear considered and demonstrate a reasonable degree of understanding of the company, with the exception being companies with a mass-market retail aspect to their business: in these cases a number of questions are raised that would be more appropriately directed at a store manager.

Communications with shareholders is considered to be one of the key functions of the board (OECD, 2004; Higgs, 2003). These minutes suggest that those shareholders who attend ASMs are 
generally happy with the quality of the communication that they receive from the company via the ASM and annual reports, although one in five of the questions raised were around reporting. In the majority of cases these questions touched on financial matters and could have been answered by a close reading of the company's annual report.

One stream of corporate governance literature (Forbes \& Milliken, 1999; Nicholson \& Kiel, 2007; Aguilera, 2005) considers that the role of the board includes setting the direction of the company, controlling management, and reporting to shareholders; analysis of these minutes suggests that boards perform all of these functions. That all resolutions regarding executive remuneration were passed with substantial majorities suggests that NZ boards do exert a reasonable level of control over management. A critical reading of chairmans' speeches that were included within the ASM minutes demonstrated that these chairmen (or whoever wrote their speeches) have a good understanding of their company's strategy and direction. However, this analysis did not give insights into how companies develop their strategy or the role of the board in this process.

Agency theory considers that the primary role of the board is to control management on behalf of the shareholders. While the minutes indicate that the boards do exert some control over management, they do not per se provide firm evidence to support the assumption that the board is working on behalf of shareholders. While an argument could be made that the high level of acceptance of all of the resolutions proposed by the boards suggests that boards are working on behalf of shareholders, other equally plausible explanations for this outcome could be made, such as Berle and Means' shareholder rational apathy argument (1932, p. 74). In this respect it should also be noted that shareholder-proposed resolutions were rejected, while all of those proposed by the board were passed with very substantial majorities. The analysis does not provide any information that suggests that either directors or shareholders favour stakeholder theory or shareholder theory. 
In summary, this analysis of company ASM minutes suggests that companies are meeting both their obligations to shareholders as required under the 1993 Companies Act and, in general they are also meeting shareholder expectations. Where they are not meeting shareholder expectations the problems are confined to specific company-related issues and are not indicative of systemic problems with governance. The minutes suggest that directors have an expectation that they control the firm and that their task is to inform shareholders, not to receive guidance and direction from them. The analysis therefore calls into question one of the fundamental assumptions underpinning agency theory, specifically that directors are agents for shareholders. The significant apparent influence that directors have over the appointment of new directors is apparent from the review of directors appointment resolutions. This finding lends support to Cadbury's (2002) observation that boards can become self-perpetuating. Overall the analysis of the ASM minutes has supported many of the comments from the shareholders and directors focus groups. So ASMs, appear to be a mechanism which reinforces rather than defines directors', and shareholders', expectations of boards. 


\section{DIRECTOR AND SHAREHOLDER SURVEY}

This chapter discusses the results of the two postal surveys that were conducted, one with directors and the other with private shareholders. The objective was to obtain a broad cross-section of these stakeholder groups' views and expectations of NZX-listed company boards. Surveys were selected as the mechanism to collect the data because they have the advantage of being able to obtain the opinions of a large segment of the population in a consistent and structured manner (O'Leary, 2010). Data were collected on the profiles of shareholders and directors, their opinions of each other, and their views regarding the roles and responsibilities of the board.

A comprehensive survey of a sample of all New Zealand directors was conducted by Van der Walt and Ingley (2005) in 2003. That survey investigated the tasks that a board should perform, the board's influence on corporate activity, and the perceived competence of non-executive directors. This survey revisits some of these themes to obtain a more up-to-date view of directors' opinions and attitudes and extends the research in some important new directions. Specifically it examines the views and opinions of shareholders, and it investigates how expectations of the board change in response to a change in the environment.

The chapter firstly examines the survey responses and shareholder and director demographics. The opinions that directors and shareholders hold of their opposite party are then outlined and this is followed by an examination of both shareholders and directors opinions regarding key aspects of corporate governance. This includes their expectations regarding: the role of the board; board activity, board shareholder communication, and board composition.

\subsection{Survey Responses}

The survey was conducted over a two-month period from June 2014. Table 30 shows the size of the surveys and the responses. 


\section{Table 30}

Written survey responses

\begin{tabular}{rrr} 
& Director & Shareholder \\
\hline Less & & 1083 \\
Returned to sender or not filled in & 11 & 35 \\
Net sent out & 389 & 1049 \\
Surveys returned and analysed & 130 & 374 \\
Surveys returned after analysis & 12 & 8 \\
Response rate & $37 \%$ & $36 \%$
\end{tabular}

To encourage directors to respond, any questions that might identify respondents were excluded from the questionnaire. This approach may have contributed to the high (37\%) response rate, which compares favourably to the $17 \%$ that was achieved in the 2003 director survey (Ingley \& Van der Walt, 2005).

\subsection{Shareholder Demographics}

Some basic demographic data were collected on shareholders in order to gain insights into their approach to the share market and their experience investing in NZX-listed companies, as these factors were considered likely to influence their expectations of boards. The areas investigated were: years investing in NZX shares, investment approach and strategy, and size of portfolio.

\subsubsection{Shareholder investment experience}

Shareholders were asked to disclose the number of years they have invested in the NZ share market; Table 31 summarises their responses. 


\section{Table 31}

Number of years that shareholders have invested in NZX shares

\begin{tabular}{rrrrrrr} 
Years & $1-10$ & $11-20$ & $21-30$ & $31-40$ & $41-50$ & $50+$ \\
\hline Shareholders & 52 & 89 & 93 & 64 & 56 & 17 \\
Percentage & $14 \%$ & $24 \%$ & $25 \%$ & $17 \%$ & $15 \%$ & $5 \%$
\end{tabular}

Total responses: 371 .

The average time that respondents have invested in the share market is 28.8 years. As the table shows, a number of investors have participated in the market for over 50 years. One respondent noted that he had spent a pleasant couple of hours answering the survey together with his shareholding father, who is 100 . While centenarians were clearly the exception, this profile does suggest that investors who invest directly in shares tend to be older people, many of whom have likely retired from full-time employment. This suggests that they may have more time, and incentive (due to their greater dependence on passive income), to devote to their investments and potentially to the affairs of the businesses that they own shares in, should they so choose.

\subsubsection{Approach to share market}

Shareholders were asked to assess their investment approach on a scale that was broadly in line with the behavioural categorisations used by the ASX in their analysis of Australian retail shareholders (ASX, 2011). The results are summarised in Table 32. 


\section{Table 32}

Shareholder investment approach

Responses

Percentage

I don't take the share market too seriously - I invest occasionally and for fun.

9 $2 \%$

I am not experienced, I rely on brokers or other experts to select almost all my shares for me.

41 $11 \%$

I am reasonably knowledgeable and I often rely on advice from brokers or other experts.

I know what I am doing and I buy and sell shares regularly.

Total

\begin{tabular}{rr}
73 & $20 \%$ \\
\hline 368 & $100 \%$
\end{tabular}

In addition, the survey results do not show any significant correlation between years investing and investment approach (Pearson's $r=0.02$ ). This suggests that shareholders do not necessarily start by having a 'dabble' and then progress to using a broker, and then on to making their own investment decisions. It also highlights the influence that institutions have with private investors, as $67 \%$ of investors surveyed state that they often rely on the advice of brokers or other experts.

\subsubsection{Investment strategy}

The possibility that a shareholder's investment strategy influences their approach to governance and their expectations of boards was considered. For example, it was postulated that investors who plan to hold shares for a long period of time may be more inclined to participate in the governance process than shareholders who trade shares frequently and hold them for only a short period. Table 33 shows the investment intentions of shareholders surveyed. 


\section{Table 33}

Shareholder investment intentions

\begin{tabular}{rrr} 
& Responses & Share \\
\hline To hold shares less than a year & 5 & $1 \%$ \\
Own shares more than a year & 308 & $83 \%$ \\
No set plan & 59 & $16 \%$ \\
\cline { 2 - 3 } Totals & 372 & $100 \%$
\end{tabular}

Table 33 shows that only $1 \%$ of the shareholders responding claimed to adopt short-term trading strategies, limiting the inferences that can be made regarding their participation in the governance process.

\subsubsection{Portfolio size}

The number of companies in which an investor holds shares may be a significant metric when considering shareholder expectations of boards. This is because the larger the portfolio, the less time the shareholder is likely to have to devote to the affairs of each company. Table 34 summarises the number of individual company shares that the respondents reported holding in their portfolio.

\section{Table 34}

Number of companies in a shareholder's portfolio

\begin{tabular}{rrrrrr} 
Companies & $1-10$ & $11-20$ & $21-30$ & $31-40$ & $40+$ \\
\hline Investors & 94 & 164 & 68 & 30 & 11 \\
Share & $26 \%$ & $45 \%$ & $19 \%$ & $8 \%$ & $3 \%$
\end{tabular}

Total responses: 371 . 
The average number of companies in which respondents held shares is 19 . Given that the average share portfolio is valued at $\$ 100,000$ (4.4.1), this implies that the average value of a shareholding in an individual company is around $\$ 5,300$ - a small percentage of most investors' total net worth. If shareholders are to participate in the governance process and exercise their votes in a thoughtful manner, then a certain amount of research into the affairs of the company will be required on the 'shareholders' part'. It is possible therefore that the large number of companies that many shareholders invest in, and the small value of the average shareholding, contribute jointly to the relatively low turnout at most ASMs and the low participation in governance matters generally. As stated earlier, it may simply not be an economically attractive use of many shareholders' time. This may therefore influence their expectations of boards and also lead to rational apathy. Given that most investors do not actively participate in the governance process, many presumably rely on major shareholders and institutions to participate in the governance process on their behalf, a tactic sometimes referred to as freeloading (Rock, 1990).

An analysis of trading volumes of all NZSX companies in August 2013 showed that the average length of time a share was held was 39 days. ${ }^{9}$ This is in sharp contrast to the findings of this research, which suggests that most individual shareholders plan to hold their shares for a year or longer. It implies that the majority of the trading is not initiated by individual shareholders but rather can most likely be attributed to algorithmic trading by institutional investors. This is potentially a significant difference in behaviour between institutional and individual investors, and has the potential to influence their attitudes to governance.

\footnotetext{
${ }^{9}$ Trading volumes for each company were provided by NZX. Average holding time was derived by dividing shares issues by volume traded.
} 


\subsection{Director Demographics}

Directors were asked how long they had been a director of an NZX-listed company. Table 35 summarises the responses.

\section{Table 35}

Years employed as an NZX-listed company director

\begin{tabular}{rrrrrrr}
\hline Years & $1-5$ & $6-10$ & $11-15$ & $16-20$ & $21-25$ & $25+$ \\
Directors & 36 & 38 & 18 & 23 & 4 & 8 \\
Share & $28 \%$ & $30 \%$ & $14 \%$ & $18 \%$ & $3 \%$ & $6 \%$
\end{tabular}

Total responses: 127.

Of those directors who responded to the survey, the average time they had served on an NZX company board was 11.4 years. Given that the average NZX director has sat on his/her current board for 6.0 years (Table 18 p.133), this suggests that many directors have careers that span multiple companies. It also shows that on average the directors who responded to the survey are very experienced.

\subsection{Directors and Shareholders' Opinions of Each Other}

In order to develop an insight into the overall relationship between shareholders and boards, both directors and shareholders were asked a series of questions regarding their opinions of each other. Shareholders were asked to rate overall board performance and directors' behaviour when a company is in crisis, and to share their views on director remuneration. Directors were asked if shareholders' expectations of returns from their NZX investments were reasonable. 


\subsubsection{Shareholders' views of boards}

Shareholders were asked how they viewed the overall performance of NZX-listed company boards in general; their responses are summarised in Figure 10.

\section{Figure 10}

Shareholders' view of board performance

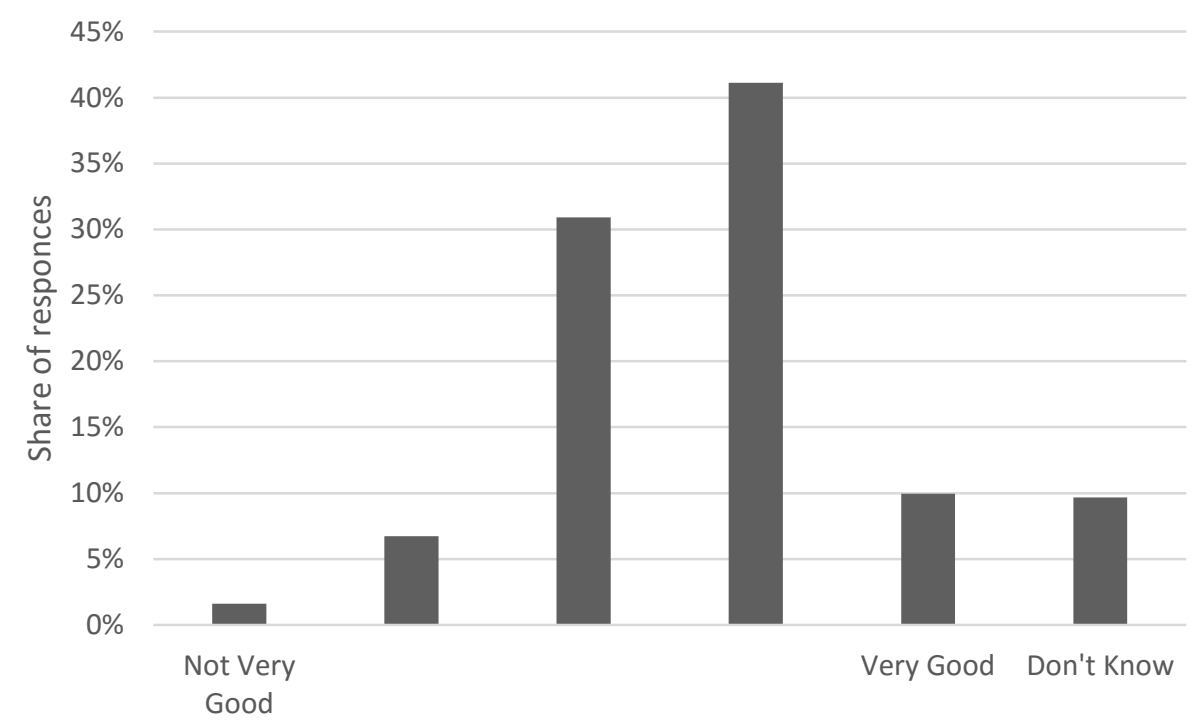

Total responses: 372 .

Figure 10 shows that overall shareholders think that boards perform well. Although shareholders are generally happy with board performance, $10 \%$ of those who responded indicated that they did not know if boards performed well; some of these respondents noted that the variability between boards' performance made it impossible to generalise across the entire market.

\subsubsection{Shareholders' view of directors' performance in crisis}

Shareholders were also asked about director behaviour when a company is in financial crisis; table 36 shows the results. 


\section{Table 36}

Shareholder opinions regarding director behaviour during a financial crisis

\begin{tabular}{|c|c|c|}
\hline $\begin{array}{l}\text { When a company is in financial crisis } \mathrm{w} \\
\text { do directors put first? }\end{array}$ & se in & ests \\
\hline Their own & 95 & $27 \%$ \\
\hline The company's & 148 & $43 \%$ \\
\hline All shareholders & 62 & $18 \%$ \\
\hline Institutional shareholders & 19 & $5 \%$ \\
\hline Employees & 4 & $1 \%$ \\
\hline Other & 4 & $1 \%$ \\
\hline Don't know & 14 & $4 \%$ \\
\hline Total & 346 & $100 \%$ \\
\hline
\end{tabular}

Fewer than half (43\%) of shareholder respondents considered that the board would follow the Companies Act (1993) and place the company's interests first. Over one-quarter of shareholders surveyed believed that in time of financial crisis, directors put their own interests above those of the company and shareholders. Many shareholders are clearly not happy with this situation and the following quote from one survey respondent sums up this sentiment: 'Board members should be held accountable in failing companies. Feltex directors, etc., get a cosy life as if nothing had happened. They should be stripped of all their assets - even those in their wives' names.' Other shareholders are more pragmatic: as another survey respondent observed, 'some go up, some go down, some directors are untruthful, and that's business'. A further 5\% consider that institutional shareholders' interests will be placed to the fore. This, together with the $27 \%$ of shareholders who consider that directors will place their own interests first, suggests a high degree of cynicism amongst the shareholder respondents. Only $18 \%$ of respondents considered that the company would 
put shareholders' interests first - this suggests that most respondents don't expect boards to act in a shareholder-centric way and it calls into question the applicability of some of the definitions of corporate governance in the New Zealand environment. For example, it is difficult to reconcile this finding with Armstrong, Guay and Weber's definition of corporate governance as 'the subset of a firm's contracts that help align the actions and choices of managers with the interests of shareholders' (2010, p. 181), or with the view of Shleifer and Vishny (1996), Monks (2001) and Macey (2008) that the primary board responsibility is to be the shareholders' advocate.

\subsubsection{Directors' views of shareholders}

Directors were asked if, in their opinion, NZX-listed companies delivered fair risk-adjusted returns. They were also asked if they considered that shareholders' expectations of returns from NZX-listed companies were realistic. Comparing the answers to these two questions gives an indication of how demanding directors believe shareholders are. Figure 11 summarises their responses.

\section{Figure 11}

Director expectations of company performance

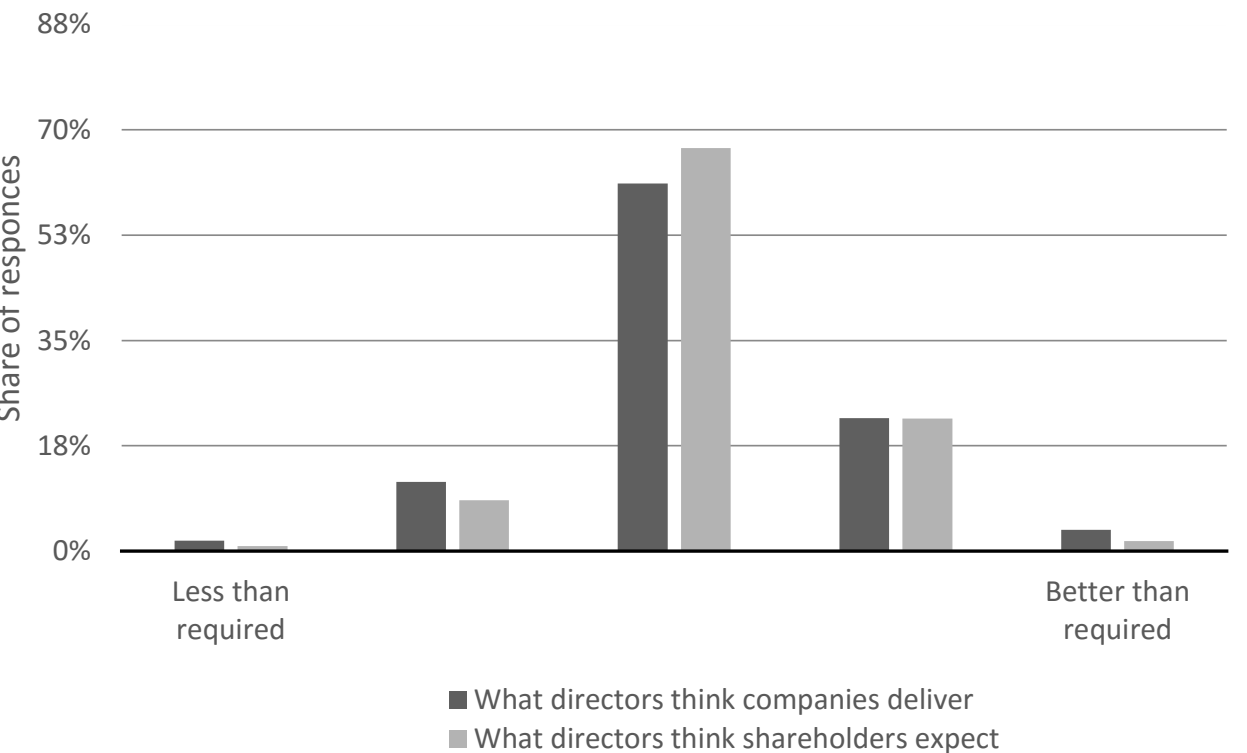


Figure 11 shows that the directors surveyed believe their expectations of company performance closely aligns with shareholders' expectations. Eighty-seven per cent of directors surveyed believe that NZX company financial returns meet or exceed expectations. These directors are also of the opinion that these returns meet or exceed $91 \%$ of shareholders' expectations. A single-factor ANOVA confirms that the difference between directors' expectations of company performance and what they believe shareholders expect is not significant $(\mathrm{p}=0.263)$. The chart therefore suggests that in general, directors believe most companies deliver adequate financial performance and this is what shareholders expect.

Some have argued that it is pressure from shareholders to produce ever-increasing returns that has encouraged many overseas boards to adopt short-term shareholder value maximisation strategies and arguably to adopt a culture of excessive risk taking (Lazonick \& O'Sullivan, 2000; Gamble \& Kelly, 2001). This finding suggests that NZ directors believe that they are meeting shareholders' expectations, which suggests that NZ directors are not subject to the same shareholder pressure as many of their counterparts in the US and the UK. This is potentially a significant difference between New Zealand shareholders' and directors' expectations of boards and their UK and US counterparts. It is also likely to influence director behaviour, and hence both directors' and shareholders' expectations of boards.

\subsubsection{Shareholder and director views on director remuneration}

Shareholders have access to director remuneration data via the statutory disclosures in annual reports, and, as will be shown in 7.7.1, many of the directors surveyed also have clear views on the roles and responsibilities of directors (and hence on the workloads of boards). As Figure 11 shows, there is a distinct difference of opinion between directors and shareholders regarding the appropriate level of director remuneration. 


\section{Figure 12}

Shareholder and director views on director remuneration

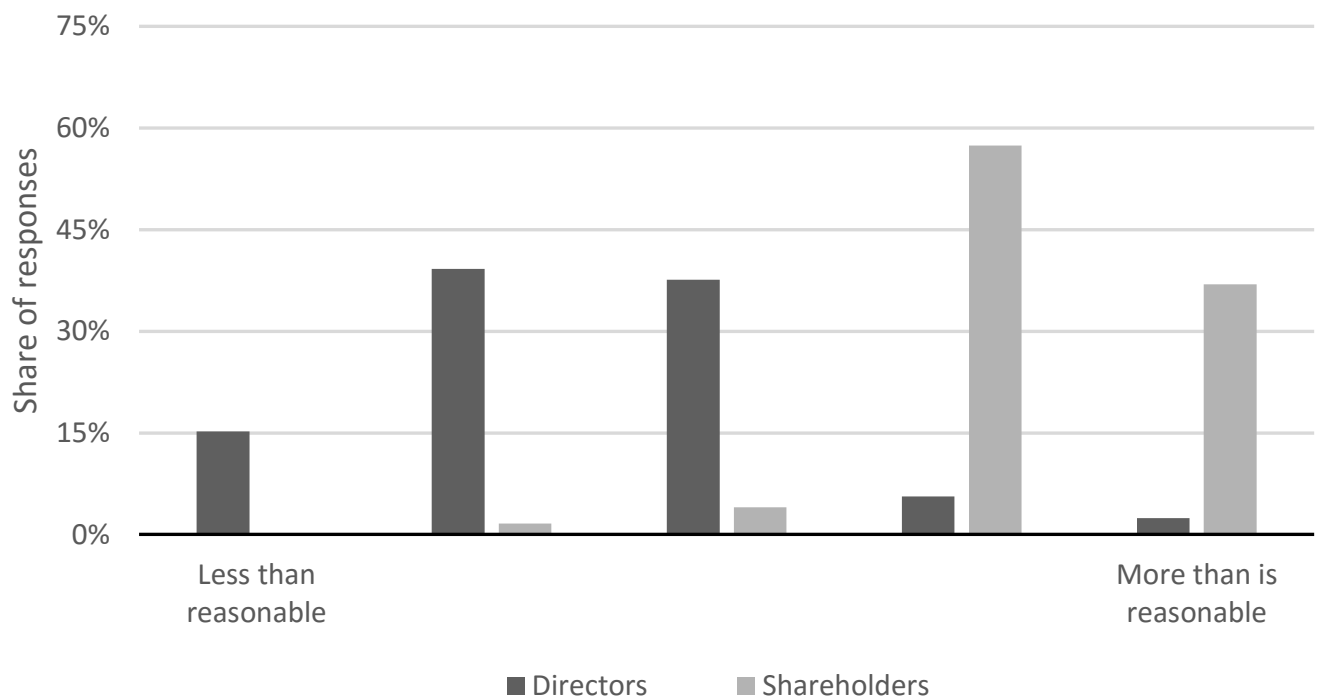

Most directors surveyed (54\%) considered they are under-remunerated, but just $2 \%$ of shareholders surveyed share this sentiment. Conversely, $94 \%$ of shareholders consider that directors are overpaid while just $8 \%$ of directors consider that they are over-remunerated $(\mathrm{T}$ statistic $=14.03)$.

\subsection{To Whom Is the Board Responsible?}

Most of the definitions of corporate governance that are shown in Table 1 imply that boards are responsible to shareholders, to the company, or to all stakeholders. In order to determine which of these parties New Zealand shareholders and directors favour, the survey asked the following question: 'In your opinion, in practice, to whom is the board responsible?' Figure 13 summarises the results. 


\section{Figure 13}

To whom is the board responsible?

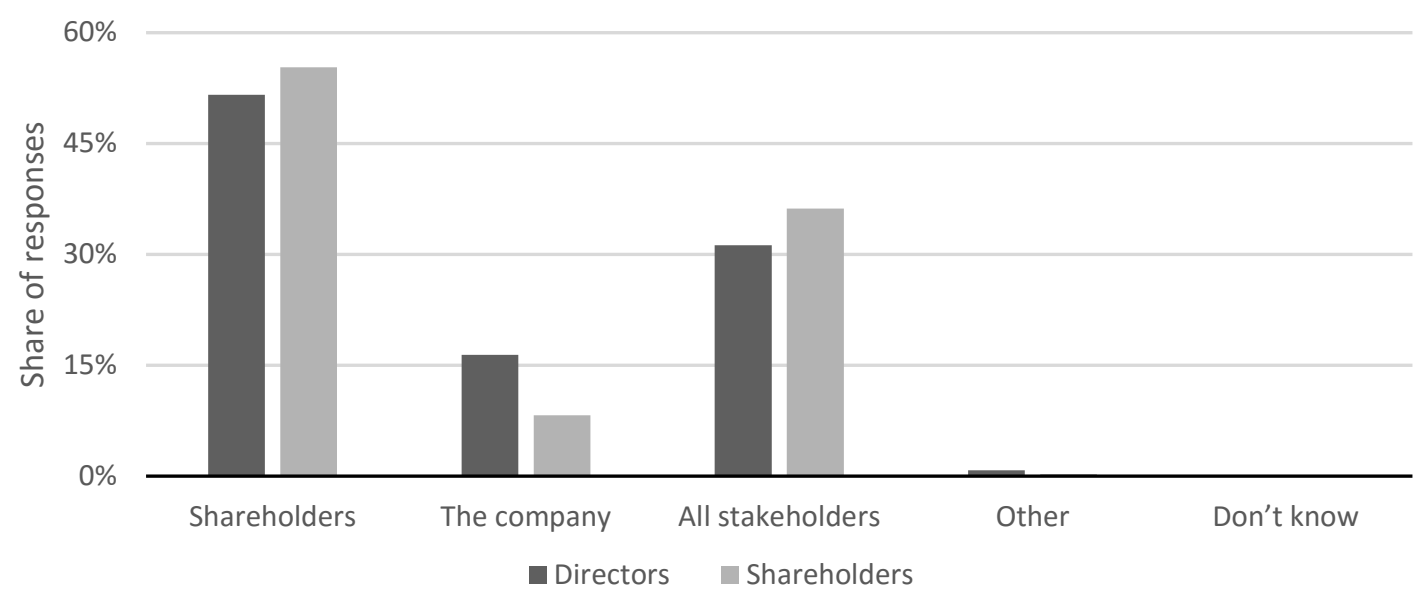

Just over half of shareholders and directors surveyed believe that the board is primarily responsible to shareholders and about a third of respondents considered that the board is responsible to all stakeholders. There is a small but statistically significant difference between the views of shareholders and directors surveyed at a $5 \%$ threshold $(\mathrm{p}=0.052)$. That the opinions of both directors and shareholders are split in this way suggests a split between a shareholder-centric approach to governance and a stakeholder-centric approach. Such a split is not unique to New Zealand, as similar debates regarding the merits of these two approaches are occurring in many countries (Vinten, 2001).

A significant minority of the directors surveyed (16\%) and the shareholders surveyed (8\%) believe that the board is responsible to the company. This cohort of respondents is maybe influenced by the Companies Act, which mandates that directors must act in the best interests of the company (1993, section 131). Further, the low figure for directors suggests the majority of directors hold personal views that are at odds with the law in this respect. 


\subsection{The Role of the Board}

Before examining the tasks a board should perform, both directors and shareholders were asked to consider the overall role of the board. The options selected were distilled from the literature discussed in section 2.2 and from the focus group discussions. Figure 14 summarises the responses.

\section{Figure 14}

Opinions on the role of the board

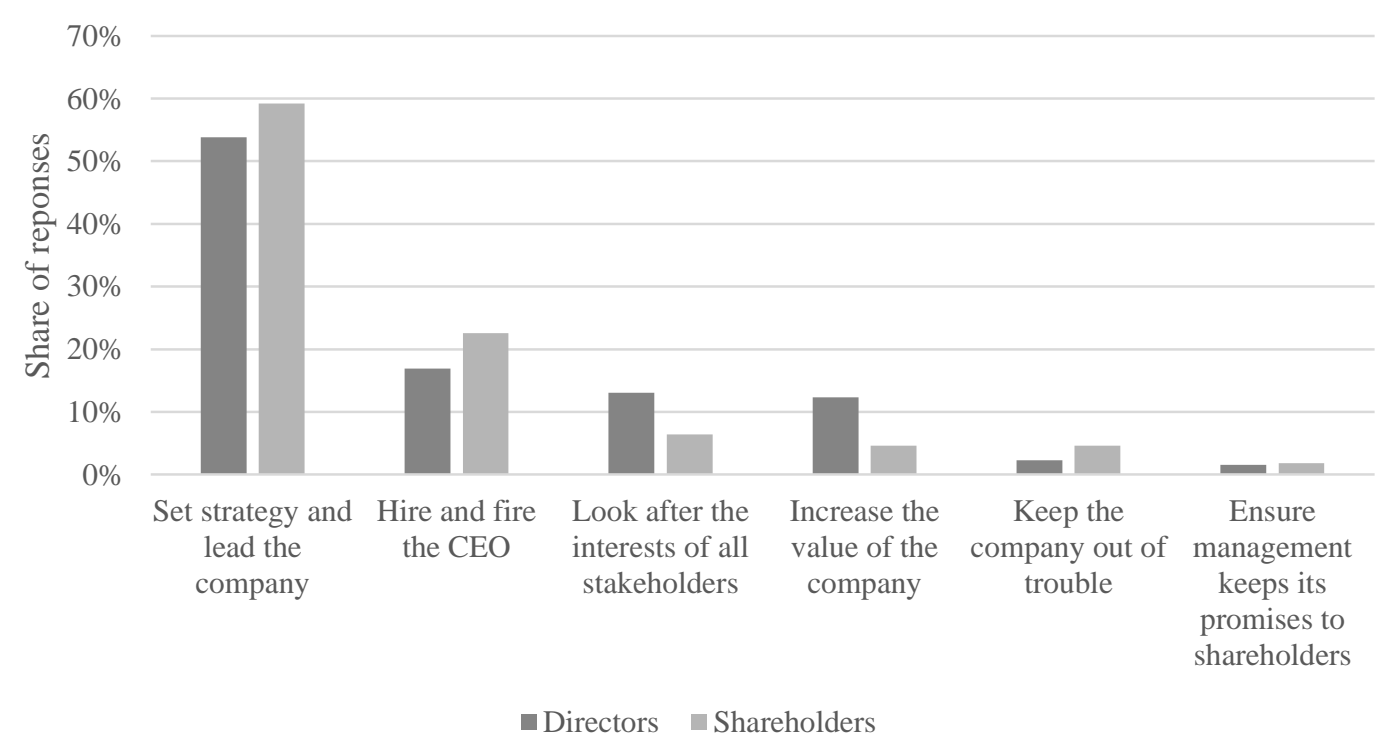

Figure 14 shows that there is no clear consensus on the role of the board. This lack of agreement has not gone unnoticed by survey respondents, and the following quote from a director is indicative of their sentiments: 'The role of public company directors and the extent of their responsibilities is not well understood by the public, including many shareholders. This gives rise to dissatisfactions in some quarters, with matters such as director remuneration.' This lack of a consensus on the role of the board reflects the different definitions of the role of the board outlined in the literature and as detailed in Table 2 (p.30). Figure 14 also shows that there is no statistically significant difference (at a 5\% threshold) between the responses of directors and shareholders (Chi-square test $p=0.005$ ). 


\subsection{Board Activity}

What boards choose to do and how they choose to act is likely to influence directors' and shareholders' perceptions of boards. From time to time differences of opinion arise between shareholders and directors over which tasks are the responsibility of the board and which are the responsibility of management. On occasion these differences have become the central issue in highprofile court cases (e.g. R vs Graham, 2012).

The survey asked respondents to consider which tasks a board should perform and which tasks should be delegated to management. They were presented with two scenarios: one in which a company was trading normally, and a second when the company was under financial stress. Two scenarios were considered because a body of literature suggests that governance practices change in response to environmental factors (Huse, 2005; Aguilera \& Jackson, 2003), and financial stress was considered a simple environmental change that was sure to gain board attention.

\subsubsection{Tasks the board should perform when a company is trading profitably}

The shareholders and directors surveyed were presented with a range of tasks and were asked to indicate who they believed should be responsible for performing them when a company was trading profitably. The options were: the board, management, joint board and management, don't know, and no preference. Figure 15 shows the share of respondents who consider that either directors on their own, or directors in conjunction with management, should be responsible for performing the range of tasks. Table 41 in Appendix C (p. 292) summarises the full results. 


\section{Figure 15}

Views on board responsibilities when a company is trading normally

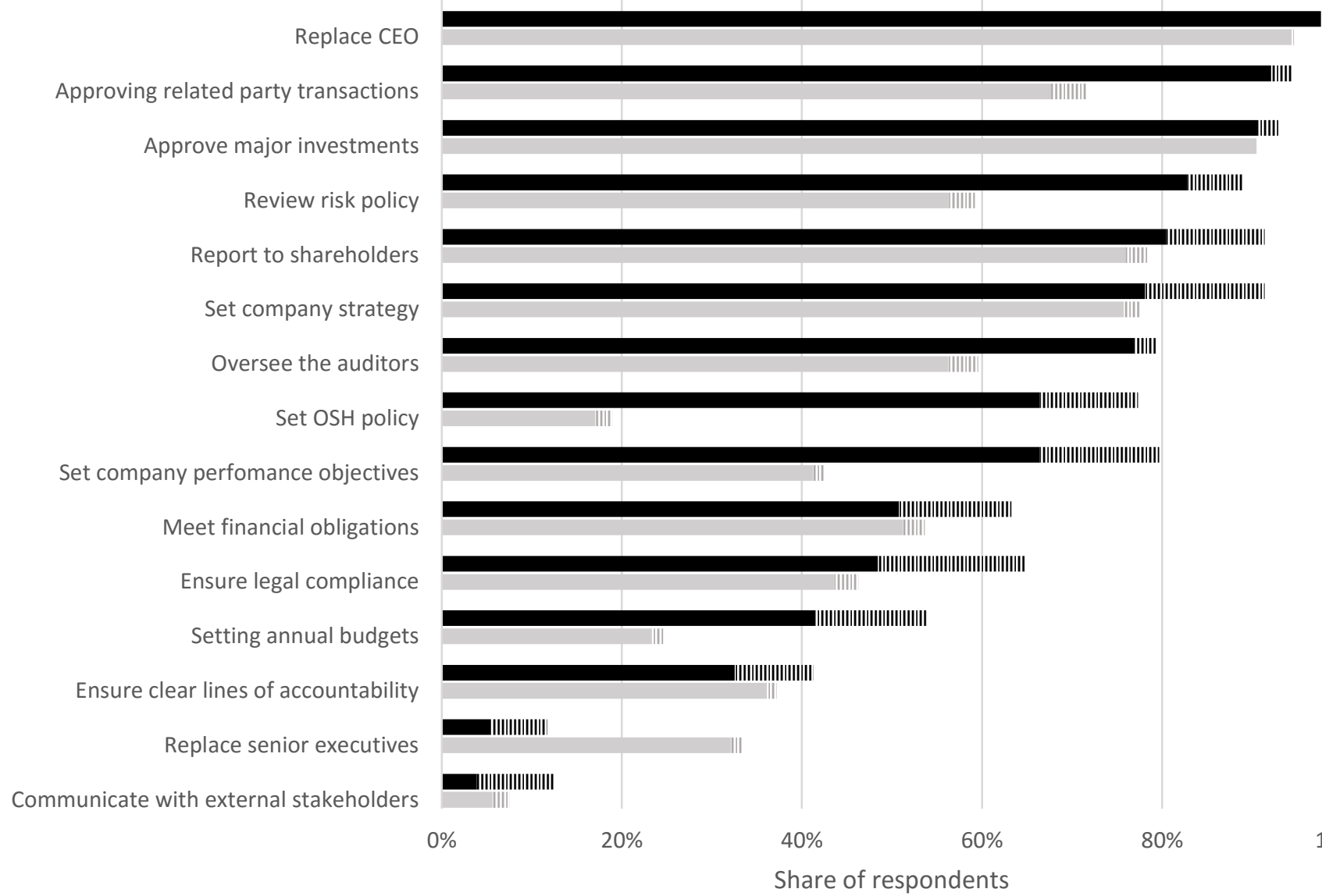

Directors: board only

Shareholders: board only
IIII Directors: board and management

IIII Shareholders: board and management

Both shareholders and directors have definite views on who should be performing all of these tasks. None of the directors answered 'don't know' to any of the questions and in only $1 \%$ of their answers did they check the 'no preference' option. Overall, shareholders answered 'don't know' to 4\% of the questions and in just $1 \%$ of their answers they indicated no preference. However, a number of the shareholders who answered this question also noted in the survey margin that it was not an area they felt qualified to comment on, or that it was not something they had previously considered. This may, in part, account for the statistically significant differences between the views of shareholders 
and those of directors. Chi-square tests (at a 5\% confidence level) indicate significant differences between the views of shareholders and directors regarding who should perform all but one of these tasks (Table 41, p. 292). The exception is replacing the CEO (chi-square $\mathrm{p}=0.556$ ): most shareholders and directors agree that is a task for the board.

Figure 15 shows there are some tasks that most directors agree should be performed by the board and there are other tasks that most directors consider should be performed by management. Seventy per cent or more of the directors surveyed consider that the board should perform the following tasks:

- when necessary replace the CEO,

- approve related party transactions,

- approve major capital expenditure,

- review and guide risk policy,

- report to shareholders.

Seventy per cent or more of directors surveyed agree that management should perform the following tasks:

- communicate with external stakeholder,

- replace senior executives.

All of these tasks fit within the boundaries of the definitions of governance and the role of the board outlined in Table 1 and Table 2. Figure 15 also shows a number of tasks where directors are divided as to who should perform them. Between $30 \%$ and $70 \%$ of directors believe that directors should perform the following:

- $\quad$ set company performance objectives,

- ensure that a company meets its financial obligations, 
- ensure that the company meets its legal obligations,

- set annual budgets,

- ensure that there are clear lines of responsibility throughout the organisation.

Taken as a group, these tasks have two features in common: all concern the day-to-day operation of the business, and all have comparatively short-term time frames. This has implications for directors' expectations of boards as it suggests that some directors believe that the board should have a more hands-on and short-term focus, while other directors appear to favour the board adopting a longer-term focus, perhaps with a greater emphasis on control and monitoring.

\subsubsection{Tasks the board should perform when a company is under financial stress}

How boards behave, and how directors and shareholders expect them to behave, when a company is under financial stress is important because it is under these circumstances that boards are under most scrutiny and their actions are likely to have the most significant impact. Comparing the normal and stressful scenarios also provides some insights into how boards may respond to environmental changes.

The shareholders and directors surveyed were presented with a range of tasks and were asked to indicate who they believed should be responsible for performing them when a company was trading under financial stress. The options were: the board, management, joint board and management responsibility, don't know, and no preference. Figure 16 shows the share of respondents who considered that either directors on their own, or directors in conjunction with management, should be responsible for performing these tasks. Table 43 (p.293) shows the complete results for all options. 


\section{Figure 16}

Views on board responsibilities when a company is under financial stress

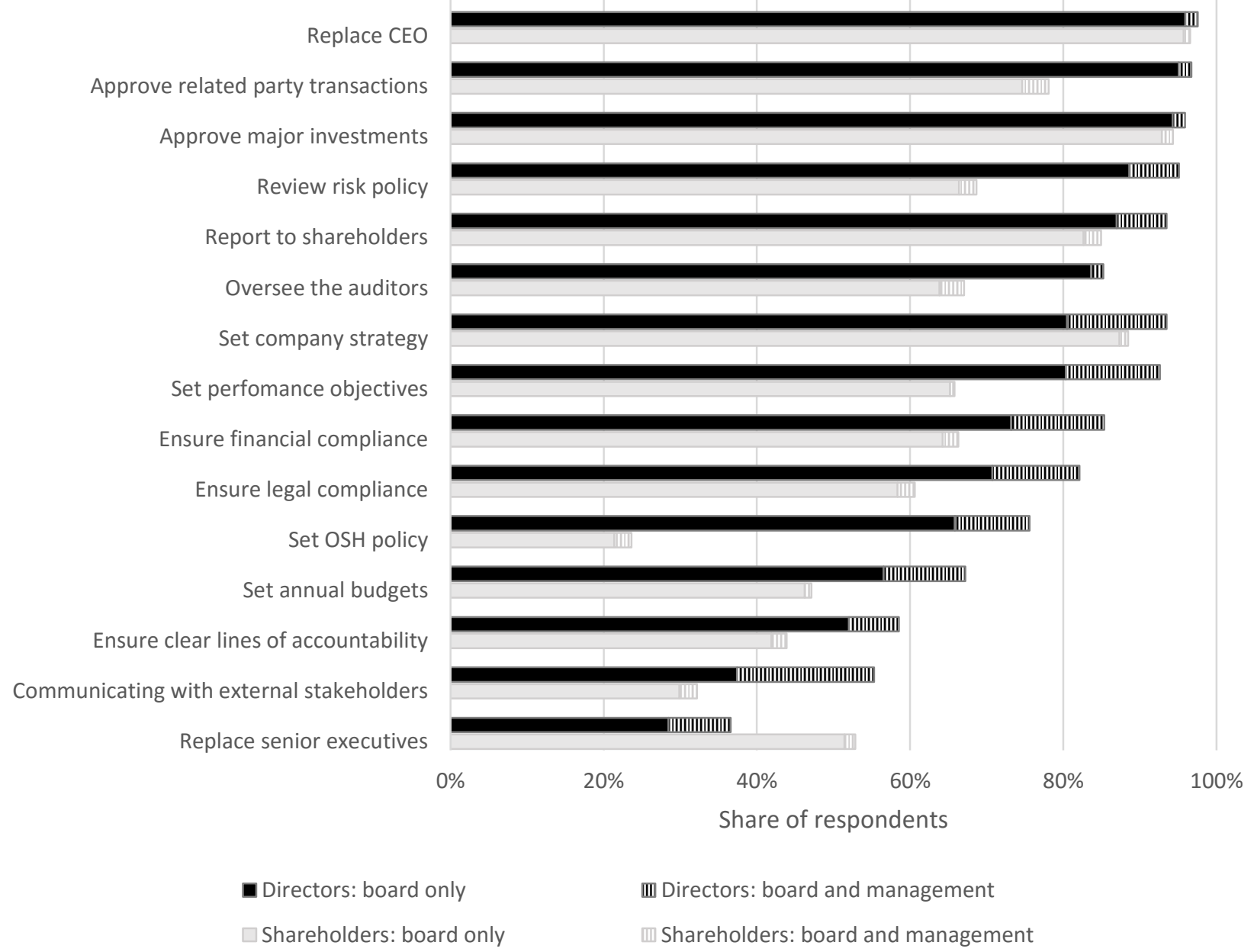

Once again a number of shareholders remarked in the margin of the survey that either they did not feel qualified to answer this question or that it was a topic that they had not previously considered. In addition, $6 \%$ of shareholders 'skipped' this question. Although there are statistically significant differences between the expectations of shareholders and directors for all but two of the tasks (replacing the CEO and approving major investments), it seems likely that many of the tasks outlined do not generally influence most shareholders' expectations of boards. 
Figure 16 also shows that when a company is under financial stress there are still differences of opinion among directors regarding many of the tasks the board should perform. The four tasks that directors were most divided over were:

- overseeing the work of auditors,

- approving related party transactions,

- $\quad$ setting OSH policy,

- ensuring clear lines of accountability throughout the organisation.

Overseeing the work of auditors and approving related party transactions are both activities that the NZX listing rules require boards to perform (NZX, 2013), so this finding was unexpected. Similarly there are significant consequences for directors should OSH policies be found wanting.

\subsubsection{Changes in stakeholder expectations that occur when a company is under financial stress}

Overall when a company is under financial stress directors expect boards to reduce the number of tasks that they delegate to management and increase the number of tasks they perform directly. Table 37 shows how directors' expectations change (Table 44, p.294 shows the detailed results). 
Directors' views on how board responsibilities change in a financial crisis

\begin{tabular}{lrrr} 
& Normal & Stressed & Change \\
\hline Communicating with external stakeholders & $13 \%$ & $55 \%$ & $43 \%$ \\
Communicating with the public & $29 \%$ & $60 \%$ & $31 \%$ \\
Where necessary replacing senior executives & $12 \%$ & $37 \%$ & $25 \%$ \\
Ensuring the company meets its financial obligations & $63 \%$ & $85 \%$ & $22 \%$ \\
Ensuring the company complies with its legal obligations & $65 \%$ & $82 \%$ & $17 \%$ \\
Ensuring clear lines of accountability throughout the & & & \\
organisation & $41 \%$ & $59 \%$ & $17 \%$ \\
Setting annual budgets & $54 \%$ & $67 \%$ & $13 \%$ \\
Setting company performance objectives & $80 \%$ & $93 \%$ & $13 \%$ \\
Reviewing and guiding risk policy & $89 \%$ & $95 \%$ & $6 \%$ \\
Overseeing the work of the auditors & $79 \%$ & $85 \%$ & $6 \%$ \\
Approving major investment expenditure & $93 \%$ & $96 \%$ & $3 \%$ \\
Approving related party transactions & $94 \%$ & $97 \%$ & $2 \%$ \\
Setting company strategy & $91 \%$ & $93 \%$ & $2 \%$ \\
Reporting to shareholders & $91 \%$ & $93 \%$ & $2 \%$ \\
Where necessary replace CEO & $98 \%$ & $98 \%$ & $0 \%$ \\
Setting occupational health and safety policy & $77 \%$ & $76 \%$ & $-2 \%$
\end{tabular}

Table 37 shows that an overall increase in the involvement of boards in these tasks is likely to occur when a company is under financial stress. Communicating with external stakeholders is the activity that shows the biggest change. It has been argued that when a company is under financial stress its external communications are far more important than under normal circumstances (Coombs, 2007), and this may account for the change. There may, however, be an alternative explanation. When a company is under financial stress directors' personal reputations are also most at risk, and given that reputation is considered by some to be the most valuable commodity that directors possess (Ong \& Wan, 2008), a desire to protect it may be the motivation behind this change.

The other significant increases in director involvement occur in replacing senior executives, ensuring a company meets its financial and legal obligations, ensuring accountability, and setting budgets and objectives. These changes suggest that in time of financial crisis some directors believe 
that they should become more involved in day-to-day management of the company and that they should focus more on short-term activities. Given that for a company in financial crisis the probability of having a long term is greatly reduced, this appears to be a rational reaction. Overall these changes support the views of Huse and others that the role of the board is contingent on the circumstance in which a company finds itself (Huse, 2005; Long, 2006).

\subsection{Board Shareholder Communication}

The ability of the board to communicate effectively with shareholders is considered by many to be

one of its key functions and is included in many corporate governance codes (OECD, 2004; General Motors, 2010). Boards must formally report on the status of their company twice a year and in the intervening periods they must report to shareholders on any events that are likely to have a material impact on the value of the enterprise (Securities Markets Act, 1998; Companies Act 1993; NZX, 2014). Effective communication has been shown to aid capital formation by providing investor confidence (Karp \& Axford, 2011). By improving access to capital, the quality of communication between a company and its stakeholders increases company value and for this reason is important to both shareholders and directors. Shareholders and directors were asked their opinion on the overall quality of communication between boards and shareholders. Figure 17 summarises their views. 


\section{Figure 17}

Views on quality of communication with shareholders

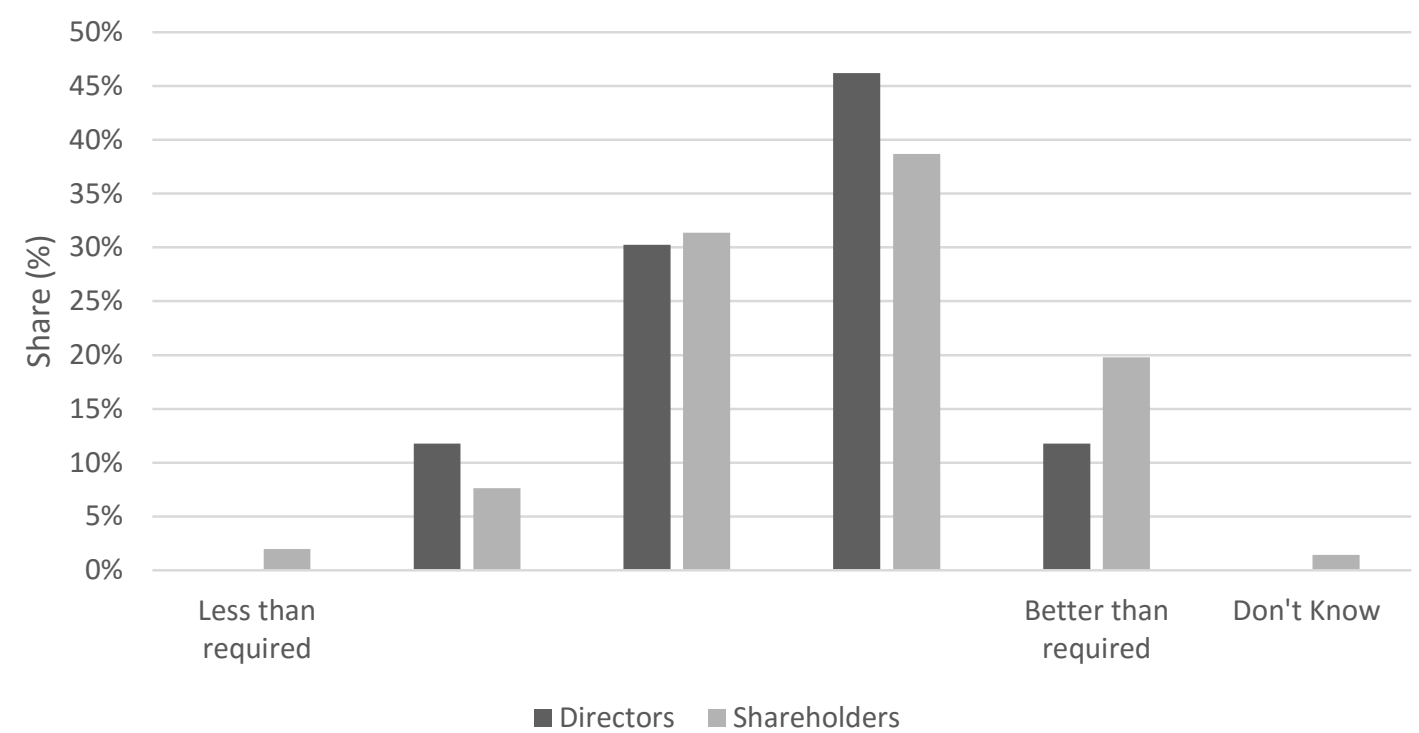

Figure 17 suggests that there is no significant difference of opinion between directors and shareholders regarding the overall quality of communications between boards and shareholders (tstatistic $=0.927)$

\subsection{Board Composition}

As discussed in section 2.5 and reinforced by the comments of the focus group participants $(5.2 .3,5.3 .3)$, the composition of the board is a key element in determining both director and shareholder expectations of boards. This section examines two elements of board composition: director independence and the role of women.

\subsubsection{Director independence}

Both directors and shareholders were asked what they considered was the appropriate number of independent directors on a board; Figure 18 summarises the responses. 


\section{Figure 18}

Views on the number of independent directors on a board

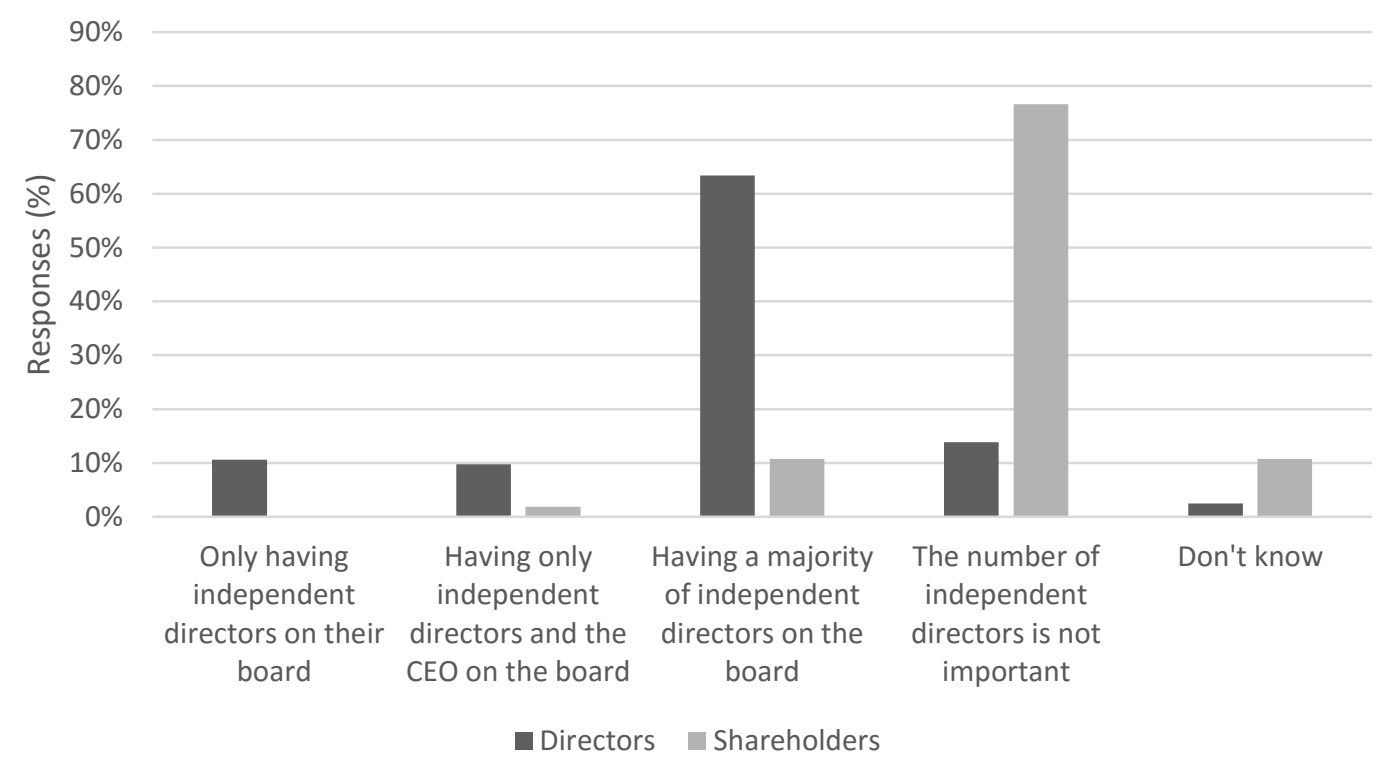

Figure 18 suggests that directors and shareholders hold significantly different opinions regarding the need for independent directors on NZX company boards (chi-square $\mathrm{p}<0.001$ ). Some $77 \%$ of shareholders believe that the number of independent directors on a board is not important, while just $14 \%$ of directors appear to share this view.

\subsubsection{Women on boards}

The level of participation of women on boards is currently a topical subject with both shareholders and directors (wob.org.nz, Fauzi \& Locke, 2012). The subject is regularly raised by shareholders at ASMs (6.3) and is also frequently raised in the popular press (Meier, 2014; Narimu, 2012). Survey participants were asked what level of female participation on the board would most benefit public companies. Figure 19 summarises the results. 


\section{Figure 19}

Views on the role of women directors

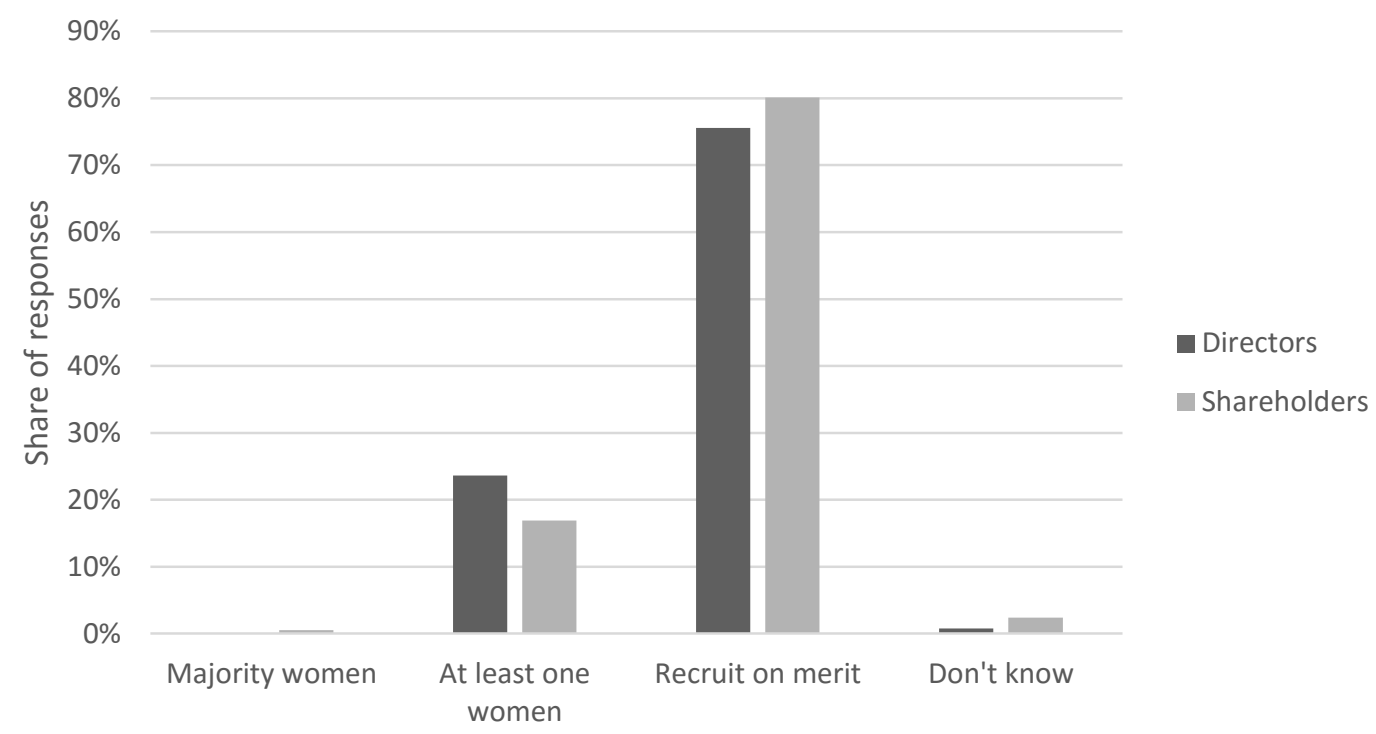

As Figure 19 shows, the majority of directors and shareholders believe that all board seats should be filled solely on merit. The differences in the views of directors and shareholders are not statistically significant (chi-square $\mathrm{p}=0.216$ ). A separate analysis of the data also shows that male and female shareholders share similar views on this issue, as a comparison of female and male shareholder responses showed no statistical significant difference in their responses (chi-square $p=0.395$ ).

In the popular press a number of pro-woman advocates and academics have been calling for quotas that ensure a minimum number of women on boards (Business Day, 2015). Directors were asked if they believed that a minimum quota of board seats should be allocated to women. Ninetyfour per cent of those who responded said no. This view appears to be quite strongly held, regardless of directors' views on the merits of women directors, as indicated by one of the respondents: 'I am a mentor for diversity within the IoD but still consider directors should be selected on "value to company" with a desire to be as diverse as the communities they represent.' 


\subsection{Summary}

The objective of the surveys was to obtain opinions from a range of directors and private investors on their expectations of boards. This objective was met with some 374 completed surveys being returned - a 36\% response rate. The data contained in these surveys has highlighted some of the elements that influence shareholder and director expectations of boards, and it has also provided insights into how directors and shareholders view each other, the homogeneity between these two groups, and the heterogeneity that exists within these groups, all of which contributes to an understanding of their expectations of boards.

The survey suggests that private investors tend to be experienced, long-term participants in the market. The shareholders who responded to the survey have been investing in NZX equities for 28.8 years, and consider themselves to be reasonably knowledgeable about the market. Most of these shareholders rely on the advice of brokers or other experts when making share purchases, which highlights the influence that institutional investors have over the market. On average they hold more than 10 stocks and have an investment horizon of more than one year. The large number of companies in which shareholders hold shares, coupled with the low average value of each holding (around \$5,300), suggests that shareholdings in individual companies are not a substantial portion of most shareholders' net worth, which may influence their approach to governance and their expectations of boards. Directors, on average, are very experienced, and of those who responded to the survey their average tenure as a director of NZX-listed companies was 11.4 years.

Overall, shareholders were happy with the performance of NZX company boards, although some shareholders commented that in their opinion there was a wide variance in the quality of governance across the NZX, which was possibly also reflected in the relatively large number of respondents (10\%) who answered 'don't know' to this question. Not all shareholders appear 
satisfied with the performance of individual directors. When asked whose interests shareholders believed that directors would put first during a financial crisis, $27 \%$ of respondents considered that directors would put their own interests first. In addition $94 \%$ of shareholders considered that directors were overpaid, possibly suggesting that shareholders do not consider most directors to be 'value for money'.

The survey suggests that directors generally believe that NZX companies are meeting shareholder expectations. In this respect NZX directors likely differ from their US and UK counterparts, who often feel under pressure from shareholders to deliver ever-increasing returns (Gamble \& Kelly, 2001). It can therefore be argued that NZ directors are under less compulsion to adopt shareholder value maximisation strategies. Both the shareholders and directors surveyed were divided on board responsibility; approximately half considered boards were responsible to shareholders, and most of the remainder were divided between responsibility to all stakeholders and responsibility to the company. Legally, boards are considered responsible to the company (Companies Act 1993), so clearly the majority of shareholders' and directors' expectations are at variance with the law.

Most of the directors and shareholders surveyed appear to have firm views regarding the tasks that boards should perform, with the two groups broadly in alignment. Most respondents agree that the board should perform tasks associated with monitoring and reporting and, when necessary, replace the CEO. Respondents were, however, divided on who should perform tasks with either an operational focus or a short-term focus. These tasks include setting annual budgets and setting company performance objectives. Should a company be in a financial crisis, some directors believe they should change their behaviour and increase their involvement with a number of tactical tasks, such as communicating with external stakeholders and the public and replacing senior executives when required. This suggests that some directors consider that the tasks a board should perform are contingent upon the environment in which a company operates. 
Respondents were canvassed on two aspects of board composition: their views on director gender and their views on independent directors. Over $75 \%$ of both directors and shareholders believe that directors should be appointed on merit. Views on independent directors were more divided, with $77 \%$ of shareholders considering that the number of independent directors is unimportant - a view shared by just $14 \%$ of directors.

A deeper analysis of the data collected in this survey failed to reveal any patterns or common characteristics which would allow either directors or shareholders to be segmented into unique groups. For example, directors who share a common view on the role of the board do not appear to share similar views on which tasks boards should perform. So overall the survey shows that both shareholders and directors hold a diverse range of views on most governance topics. 


\section{DISCUSSING THE FINDINGS OF THIS STUDY}

This chapter examines the findings of the research presented in chapters 4 to 7 in order to address the primary research question: what do New Zealand's shareholders and company directors expect from New Zealand's public company boards? It also addresses the two supplementary questions, which are: (1) how heterogeneous are the shareholders and directors in their expectations of NZ boards, and (2) as groups, how homogeneous are shareholders in their expectations of boards and how homogeneous are directors in theirs?

The chapter first considers the author's likely influence on the research. It then considers the research related to the environment in which corporate governance is practised, the aim being to identify some of the key environmental factors capable of influencing shareholders' and directors' expectations of boards; this will draw largely on the research regarding the NZ environment that is outlined in chapter 4 . The chapter then addresses those expectations, by drawing on the data collected in the research initiatives detailed in chapters 5, 6 and 7.

\subsection{The author's influence on the research}

The research has been approached from a relativist ontological perspective which assumes that the researcher is not independent of the environment. Therefore it is useful to discuss the author's likely impact on the collection of the data, the presentation and interpretation of the findings before proceeding to a detailed discussion of the findings.

The key personal factor that has potential to influence the research in my perspective is my 25 year experience as a company director. Having experienced many of the circumstances raised in the research, such as governing companies in financial difficulties, I could provide a greater insight into the issues and could make connections between data sets that would have otherwise have been the case. As will be discussed, my background also created limitations for the research and I have 
an inherent bias towards directors. For this reason I have remained mindful of my background throughout the research process.

The research into the New Zealand environment (4.0) drew on data from secondary sources and the process of collecting and presenting the data was mechanistic in nature. Because of the relatively unambiguous nature of these data I suspect my background did not significantly influence the conclusions drawn directly from them.

The focus group research has undoubtedly been influenced by my background. The members of the director focus group were some of New Zealand's most experienced public company chairmen and it is unlikely that they would participate in such an event had I not been able to use my personal network to attract them. My experience as a director, the topics I raised, and the language I used during the focus group along with my empathy for their views are all likely to have influenced the interview. My sense is that my background allowed me to very quickly establish rapport. The nature of the discussion was such that I was considered very much a peer and my perception is that this probably resulted in a more open an honest discussion than might have occurred had I not been a professional director. The shareholder focus group also benefited from my personal network in that I was able to attract shareholders from a wide range of backgrounds who might otherwise have been reluctant to attend such an event. Many of the questions I asked in order to prompt discussion were based on my experience interacting with shareholders while working as a Managing Director. Significantly most of these questions were not readily apparent from the governance literature - however they were of interest to shareholders. Although the interview was conducted on 'neutral ground', the focus group members were well aware that I was the managing director of a publicly-listed company and that on occasion their comments were prefixed with statements such as "not that you do this David but..." However, given the relaxed nature of the interview, the free flowing discussion, and the fact that focus group members frequently debated the 
questions amongst themselves with no reference to me, I do not believe that my presence inhibited or in any way restrained the focus group members in their comments.

The analysis of ASM minutes (6.0) was also influenced by my background. A number of companies were reluctant to release their minutes for analysis until they discovered my background at which point they agreed to release them. This substantially increased the amount of raw data that I was able to obtain and hence increase my confidence in the findings. While much of the analysis was qualitative and again largely mechanistic the analysis of shareholder questions was open to some interpretation as there was a subjective element involved in categorisation of shareholder questions and assigning specific questions to these categories. My background and experience at ASMs assisted me with this process.

The director and shareholder surveys were likely also influenced by my background. Using my network gave me access to a database of shareholder names and addresses that would otherwise have been difficult to obtain. My public reputation was considered when drafting the director survey. Because I was known to some of the directors surveyed, particular attention was placed on ensuring the surveys were anonymous and so no company specific data were collected. The content of both surveys was also influenced by my background. While the questions included in the survey were derived from the literature review and the focus group interviews, the language used and the slightly informal tone of the survey were both influenced by my experience working with directors and shareholders. This may have made the survey more accessible to the respondents and contributed to the relatively high response rates.

On balance I consider that my experience as a managing director has enhanced this research more so than it served to bias the results. While the opportunity to collect certain data was forgone, the key benefits were being my ability to access people and data that would not generally be 
available to researchers, as well as my personal experience providing insights into many of the issues discussed outweighed these limitations.

\subsection{NZ Public Company Boards and the Environment in Which They Operate}

The corporate governance literature makes it clear that governance models and practices vary from country to country, and it also highlights the areas where variations between countries are most likely to occur (Davies \& Schlitzer, 2008; Agarwal et al., 2007). However, the literature has neither systematically nor comprehensively assessed the New Zealand corporate governance environment. It was necessary to address this shortfall in order to identify the specific environmental factors that can have a material influence on NZ directors' and shareholders' expectations of NZ boards. This research has identified several environmental factors that have potential to influence directors' and shareholders' expectations of boards. These factors include: the underlying approach to corporate governance in New Zealand, the legal environment, and company, shareholder and director demographics. These factors are discussed in the following sections.

\subsubsection{The New Zealand approach to corporate governance}

NZ has adopted a variant of the Anglo-Saxon model of corporate governance (4.1). This research has identified some elements of the model that may potentially influence the expectations that NZ shareholders and directors have of NZ public company boards. These elements are:

- The roles of chairman and CEO are separated. It is neither a legal nor an NZX listing rule requirement to separate the roles of chairman and CEO. However, in NZ it is considered best practice, and so all current public companies on the NZSX have separated these 
functions (4.5.1). This influences the relative power of the board and management, which may, in turn, influence the expectations of directors in respect of tasks that they consider should be performed by the board and the tasks which should be performed by management.

- Shareholders are able to table resolutions at ASMs. While the ability to table resolutions at ASMs may contribute to creating the sense of ownership that some small shareholders express towards the companies they hold shares in (5.3), in practice shareholder resolutions are seldom tabled at ASMs and are rarely, if ever, adopted (6.2). This suggests that the perception of ownership, which entails power or control of an asset, may be more imagined than real.

- The majority of directors are independent. As is shown in Table 17 (p.133), approximately three-quarters of NZSX-listed companies have boards with a majority of independent directors. Independent directors are those who do not have strong financial ties to the companies they govern and so their motivations may well be different to those of inside directors, who have stronger financial ties. This will be discussed further in section 8.3.1.

- Light-handed regulatory approach. New Zealand lacks both the 'comply and explain' approach of the UK (2.4.1) and the prescriptive rules-based approach employed in the US (2.4.2), having instead adopted a light-handed middle ground. The implications of this on directors' and shareholders' expectations of boards will be discussed in detail in the following section.

\subsubsection{Legal environment}

While there are numerous laws that can potentially influence both director and shareholder expectations of boards, this research has focused primarily on the Companies Act 1993, NZ 
Securities legislation and the NZX listing rules. These laws and regulations were selected for consideration because they all include clauses that are specifically directed at company directors and so, in the author's opinion, have the most influence on board behaviour. Overall, the regulatory environment surrounding NZ governance appears to be light-handed relative to many other jurisdictions. By comparison, the US, through mechanisms such as the Sarbanes-Oxley (2002) and Dodd-Frank (2010) Acts, has adopted a highly prescriptive and regulatory-intense version of the Anglo-Saxon governance model. The UK, on the other hand, has adopted a governance model that is less regulatory-intense, yet relies more heavily on corporate governance codes and Cadbury's 'comply or explain' doctrine (Cadbury, 1992). New Zealand's corporate governance model is relatively light on both regulation and corporate governance codes, and this in turn may provide NZ boards with more latitude and freedom than their UK or US counterparts (4.1).

The legal environment also places a number of hurdles in front of any entity that considers making a hostile takeover of an NZX-listed company. Many of these hurdles are contained within the 1993 Takeovers Act. However, other factors, such as directors' appointments being staggered (which makes it difficult to replace all board members in timely manner), also impedes takeovers. The net result is that hostile takeovers of NZX companies are rare and so directors are unlikely to be concerned about them (4.3.3.). This suggests that they face less pressure than their UK or US counterparts to pursue short-term shareholder value maximisation strategies, as there is little threat of losing their positions due to perceived underperformance of their company and a subsequent hostile takeover.

Notwithstanding New Zealand's light-handed regulatory approach, a trend has been identified that shows this is slowly changing, as in recent years regulators have increased the penalties in much of the legislation targeted at directors and are making corporate governance more prescriptive and rules-based. For example, the Financial Markets Conduct Act (2013) and the proposed Health and Safety Reform Bill (Bridges, 2015) are both relatively prescriptive. There is 
also an increasing willingness by regulators to enforce these penalties, which include substantial fines and, in extreme circumstances, incarceration (4.1). This, therefore, is a trend that is likely to influence both directors' and shareholders' expectations of boards and director behaviour.

\subsubsection{NZ public companies}

Berle and Means (1932) observed that the relationship between directors and shareholders is influenced by the degree to which share ownership is dispersed and shareholder control is centralised. These parameters are not presently well understood for New Zealand public companies, so a sample of the 40 companies was analysed to determine the current situation (4.3.2). Of the companies reviewed the total number of shareholders ranged from 846 to 49,646, with an average of 10,$971 ; 10 \%$ of companies had fewer than 1000 shareholders and $38 \%$ had fewer than 5000 shareholders. Because many companies have few shareholders, their shares are infrequently traded and their stocks are considered to be relatively illiquid. This lack of liquidity is a factor that may influence block shareholders' expectations of boards. If a shareholder cannot easily exit a firm then they may consider themselves an owner, rather than an investor, and may therefore be more inclined to actively participate in the governance of the company.

Ownership concentration in New Zealand is generally high: in 38 of the 40 companies analysed just $2 \%$ of shareholders held $50 \%$ or more of the shares. While this is a high concentration of ownership, the statistic is not as significant as it may first appear, given that $2 \%$ of the average company's shareholding equates to some 219 shareholders. Therefore, $2 \%$ of shareholders in most companies still represents a sizable group from which to obtain a consensus should an individual shareholder wish to exert a high degree of control over the company. From a practical perspective, a shareholding of $20 \%$ or more is often considered sufficient to control a public company (Maume \& Walker, 2012). Using this definition of control, just $33 \%$ of the companies surveyed had a single 
controlling shareholder. This relative lack of direct shareholder control affords directors of most NZ companies a considerable degree of freedom, which undoubtedly influences both their behaviour and their expectations of boards - and it may also have a corresponding flow-on effect to shareholders' expectations.

These company ownership statistics also highlight the challenges in making assumptions that apply to the entire market, as it is likely that controlling shareholders and the directors of companies with controlling shareholders have different expectations to other directors and shareholders where the shareholdings are more dispersed. For example, shareholders may choose to become more engaged with the governance process than would have been the case if they had invested less in the firm. Furthermore, it is probable that all controlling shareholders, including company founders, government shareholders and institutional investors, may well have different goals and objectives from each other and may therefore not be homogeneous in their expectations of boards (Boone et al., 2011).

\subsubsection{Political and social influences: the appointment of women directors}

From time to time events and trends that are occurring in the broader commercial environment or in society at large spill over and influence the corporate governance of NZX-listed companies. Currently the most significant social influence is the widespread call for more women directors on public company boards (4.5.4). This research shows that, overall, boards have responded to this call by appointing increasing numbers of women to boards as independent directors (Table 20, p. 136).

Both directors and shareholders are in general agreement in their views regarding the appointment of women directors, as over $75 \%$ of both groups surveyed believe that directors should be appointed on merit (Figure 19, p. 205). Their requirements in this regard are being met, as a review of the professional backgrounds of male and female directors appointed in 2013 showed that both men and women had similar academic qualifications and similar overseas experience, were 
equally likely to have held either CEO or GM roles, and were equally likely to have a legal background (Table 26, p. 145). There are, however, two significant differences between male and female appointees that the review of newly appointed directors revealed, which suggest that male and female applicants for board positions are not always treated equally. Firstly, of the 16 women appointed to boards in 2013 only one was an inside director (Table 26, p. 145), suggesting that major shareholders and independent directors may have different views on the importance of female directors. Secondly, women who are appointed to boards are less likely to have a finance background than their male counterparts. Of the 36 directors appointed in 2013 with a finance background, only three were women. Given that $28 \%$ of CFO positions in New Zealand are held by women (Grant Thornton, 2012), it seems unlikely that there is a shortage of suitably qualified female candidates, so this finding appears at odds with the overall population. Nothing was identified from the data collected that would explain this anomaly.

\subsubsection{Shareholders}

The findings of this research suggest that shareholders are not a homogeneous group. They range from individuals with small personal shareholdings to large multinational organisations with multibillion dollar investments. Given this diversity in scale it is to be expected that their motivations and their expectations of boards will vary. To assist with understanding their underlying motivations and expectations of boards, shareholders have been classed in four segments: private investors, institutional investors, block shareholders and foreign investors.

\section{Private investors}

Numerically, private investors are the largest shareholder segment among New Zealand private investors. Approximately $16 \%$ of the NZ adult population invest directly in shares (Table 13, p. 118). The survey found that, among the respondents, the average shareholder had been investing in shares for 28.8 years (7.2). Although most of these shareholders consider themselves to 
be reasonably knowledgeable and confident in making investments, some $78 \%$ rely at least in part on the advice of brokers or other experts (Table 32, p. 184). This is an example of the influence that institutional investors who also act as share brokers can have in the market.

Based on this research the value of the average private investor's portfolio is estimated at approximately $\$ 100,000$ and consists of an investment in 19 companies (4.3.1), implying an average investment of about $\$ 5,300$ per company. This small average investment value and the large number of companies in which investors hold shares may partially explain why the analysis of company AGMs discussed in chapter 6 suggests that most shareholders do not appear to actively participate in the governance of the companies that they own shares in. Berle and Means (1932) identified a similar situation with US shareholders; they labelled the phenomenon 'rational apathy', while others have called it 'freeloading' (Rock, 1990).

Most private investors surveyed appear happy with the performance of NZX company boards (Figure 10, p. 188), and the analysis of ASM minutes did not suggest that shareholders in general held any major or systemic concerns regarding the performance or operation of NZX company boards. This general contentment, alongside rational shareholder apathy (Berle \& Means, 1932), may also contribute to the low turnout observed at ASMs. However, this general contentment does not lead to a uniformity of expectations of boards; as will be shown in section 8.3.7 a degree of heterogeneity exists within this group.

\section{Institutional investors}

Institutional investors play a complex and influential role in the operation of the New Zealand share market (4.3.2). A limitation of this research is that the chief executives of some major financial institutions that are significant investors in the NZX markets, who were contacted in the course of this research, declined to be interviewed. This reluctance was likely also reflected in the attitudes of the senior directors who, when interviewed for this research, were also unwilling to 
discuss the role of institutional investors in any detail (5.2). Nonetheless, by analysing institutional investors' shareholdings and drawing on other research it has been possible to form a clearer picture of their influence on both boards and shareholders, and this provides some insights into their expectations of governance. Institutional investors likely influence the governance process in a number of ways, including their roles as block shareholders, active traders of shares, and brokers. As a block shareholder, they generally have direct access to the chairman and other key board members. As brokers, they publish research on NZX companies that, according to the survey results, influence private shareholders (Table 32, p. 184). There is evidence to suggest that institutional investors also influence the behaviour of boards through direct dialogue with directors (Chiu \& Monin, 2003). The ability to influence both boards and shareholders, combined with their relationships with fellow institutions, places institutional investors in a unique position. A perception among many of the private shareholders and directors interviewed for this research is that institutions are focused on increasing short-term shareholder value (5.3.2). While this view is probably consistent with the mandates of many institutions, this research has found no evidence to directly support or refute the perception.

\section{Block shareholders}

For the most part, block shareholders can be categorised as either institutions, government, or company founders and their related parties, although there are situations where private individual shareholders with no ties to the company or its management have also amassed block shareholdings (4.4.5). The relative illiquidity of such blocks of shares, their high value, and the influence that voting these share parcels can have over the adoption of resolutions are incentives for block shareholders to actively participate in corporate governance matters. However, this incentive to become involved in corporate governance is possibly where the similarity between the different categories of block shareholders ends. While the precise nature and motivations of these institutions, government bodies or company founders is beyond the scope of this research, as 
discussed in section 4.4, it is likely that there are differences in the attributes of each of these investor categories. For example, each category may have different investment horizons, or they may vary in their ability to provide additional capital and in their appetite for risk. These differences may lead to differing expectations of boards.

Foreign investors

This research suggests that foreign investment in NZSX-listed companies is mainly by institutions who usually hold non-controlling blocks of shares (Table 14, p. 126). In general, foreign institutional shareholders tend to make investments in larger companies whose shares are actively traded - although there are exceptions, as there are smaller companies that are majority owned by offshore investors. This finding is consistent with Ferreira and Matos (2008), who observed similar practices by offshore institutions in other markets.

\subsubsection{Directors}

The following table summarises the key demographic data regarding directors that has been compiled in this research. 
Table 38

Directors of NZSX boards summarised (2013)

\begin{tabular}{lrrr} 
Year & Number & Share (\%) & Reference \\
\hline Seats held by independent directors & 417 & $62 \%$ & Table 18 \\
Seat held by non-executive inside directors & 175 & $26 \%$ & \\
Directors who hold CEO position & 70 & $10 \%$ & 4.4 .1 \\
Executive directors excluding CEO & 10 & $1 \%$ & 4.4 .1 \\
Total number of board seats & 672 & $100 \%$ & Table 22 \\
& & & \\
Directors who sit on one NZSX board only & 497 & $87 \%$ & Table 23 \\
Directors who sit on two or more NZSX boards & 71 & $13 \%$ & Table 23 \\
Total number of directors & 568 & $100 \%$ & Table 23 \\
& & & Table 21 \\
Seats held by directors based offshore & 137 & $20 \%$ & 4.5 .4 \\
Women directors & 87 & $13 \%$ & 4.4 .3 \\
Years directors held current role (average) & 6.0 & & 7.2 \\
Years as public company director (average) & 11.4 & &
\end{tabular}

\section{Executive directors}

Executive directors are company employees who sit on their companys' board. Table 38 shows that in 2013 , executives filled $11 \%$ of all board seats. This was a substantial (45\%) decline from 1995 , when $22 \%$ of board seats were filled by executives (Table 16, p. 131). Of the executives who held board seats in 2013 the majority were CEOs. However, overall CEOs only sat on $63 \%$ of the boards (4.5.1). In 2013 only $1.5 \%$ of all board seats were held by executives who were not CEOs. A close examination of the background of these executives reveals that most were either substantial shareholders in their own right or were affiliated with a substantial shareholder; thus this research suggests that CFOs and other second-tier executives cannot expect board roles by virtue of their position within the company. None of the CEOs held the position of chairman. Overall, this suggests that boards are becoming more independent of management. The analysis of the questions 
raised at the ASMs (6.3) did not show any suggestion that shareholders had any specific issues or concerns with respect to executive director board appointments or lack thereof.

\section{Independent directors}

Once again Table 38 highlights the significant role that independent directors play in the governance of public companies, in that they hold $62 \%$ of New Zealand public company board seats. The proportion of boards with a majority of independent directors grew from almost a half in 1995 to three-quarters in 2013 (Table 16, p. 131). There is no apparent legislative or environmental explanation to explain this trend. A similar trend has been observed in the US, again with little explanation (Gordon, 2007). One possible explanation for this increase is that it is simply a function of companies maturing and the reluctance of institutional investors to be involved in corporate governance. Over time company founders retire, lose influence and stand down from boards, while most institutional investors choose not to be appointed to boards (Ingley \& Van der Walt, 2004), so it is likely that the most eligible and available candidates left may be independent directors.

This trend of an increasing number of boards being dominated by independent directors may have implications for the expectations that directors and shareholders have of boards. Analysis of director appointments (6.2) suggests that the incumbent board members influence the appointment of new directors. This in turn suggests that the phenomenon of directors appointing their successors and boards becoming self-perpetuating may be occurring in New Zealand (Cadbury, 2002). Another consequence of this trend is that boards are weakening or breaking their direct ties with major shareholders and, in so doing, becoming more autonomous. This is a significant trend from both a director and a shareholder perspective as it raises many of the issues first identified in the US by Berle and Means (1932) where, as a result of such rational shareholder apathy, shareholders cede their influence over their investment. While Berle and Means were concerned about ceding power to influential and potentially exploitative managers, in the New Zealand case it would appear that power could be being ceded to increasingly independent boards. 
The increasing number of independent directors and the low number of executive directors on boards may influence boards' ability to perform certain tasks. For example, it is sometimes argued that boards with a majority of independent directors are more objective in their monitoring of company performance (Kosnik, 1987). Conversely, the NYX sees a potential risk when boards have just one executive. NYX's concern is that boards with one or no executive directors may lack the required in-depth knowledge of the company to adequately perform their tasks (NYX, 2010).

\subsection{Director and Shareholder Expectations of Boards}

In this section shareholders' and directors' expectations of boards are considered from the following aspects: board appointments, whom the board should serve, the role of the board, the tasks the boards should perform, and external board communications. The homogeneity and heterogeneity of both shareholders' and directors' expectations are also evaluated and the contingent and dynamic nature of their expectations is also discussed.

\subsubsection{Board appointments}

Precisely who is appointed to company boards is a topic of keen interest to both directors and shareholders (Chapter 5). However, both groups have very different expectations regarding these appointments, and these differences may be influenced by the disparate relationships the two stakeholder groups have with boards. The focus group interviews suggested that directors are more interested in how the skills and personalities of prospective directors could contribute to the operation of the board team (5.1.3), while shareholders appear to be more concerned with the public profile and the gender of prospective board members (5.2.3). This could be because less tangible aspects of directors' profiles are more difficult for shareholders to assess in the context of the tasks that they are required to perform. 
For shareholders, board appointments can, at times, be a contentious issue. This is best illustrated by the results of the analysis of the ASM minutes (Chapter 6); across the 50 meetings whose minutes were analysed a total of just four motions were tabled by shareholders and all of these motions related to shareholders nominating directors (6.2). Furthermore, as Figure 9 (p. 174) shows, $10 \%$ of the questions raised at ASMs related either directly to director appointments or to the lack of female representation on the boards. This suggest that private shareholders (who ask the vast majority of questions at ASMs) are not always completely happy with the candidates that directors nominate. Regardless, all of the directors nominated by the board were appointed and all of the directors nominated by shareholders failed to be appointed. In the cases where the results of the voting were recorded in the minutes, those directors nominated by the board were elected with a majority of at least $96 \%$ of the votes cast. However, it cannot be assumed that the high number of votes cast in favour of board-appointed directors implies a correspondingly high level of shareholder approval, as factors such as shareholder apathy, proxy voting by directors, and the impact of block shareholders can all influence this statistic.

The analysis of ASM minutes shows that directors nominated by the current board were always appointed; therefore directors have a significant influence over the board appointment process. Analysis of the backgrounds of recent board appointments can yield an insight into the attributes that directors value when making board nominations. Such an analysis was conducted and is detailed in section 4.5.7; in summary it concludes that the most common attributes found in recent director appointments are a background either in the finance profession or as CEOs, and that most new directors also have international experience and a postgraduate degree.

One limitation of the research was its inability to analyse either the social ties between directors or any of their behavioural traits. This is unfortunate, given that the focus group interviews with both directors and shareholders identified both of these factors as significant criteria in director appointments (5.2.3). The directors interviewed considered that strong personal networks and high- 
profile reputations were important and of value to a board, while shareholders interviewed had mixed views regarding the value of such networks and profiles (5.3.3.).

Directors and shareholders appear to hold differing opinions regarding the importance of director independence (Figure 18, p. 204). Some $63 \%$ of the directors surveyed believe that boards should have a majority of independent directors, and $10 \%$ believe that boards should comprise only independent directors and the CEO, while $77 \%$ of those shareholders surveyed believe that the number of independent directors on a board is not important. Given that the major justification for having independent directors on a board is to protect shareholders' interests (Orr et al., 2005; Koerniadi \& Tourani-Rad, 2012), and that there is sometimes a trade-off between director independence and overall company performance (Donaldson \& Davis, 1994; Hossain, et al.; Gordon, 2007), this is potentially a significant finding.

So while one of the few areas where a significant difference of opinion between shareholders and directors was identified, in practice this difference does not appear to cause any significant problems. For example, the analysis of questions raised at ASM minutes suggests that in general shareholders are ambivalent towards director status, as the issue of director independence was not raised as an objection to the appointment of any director per se.

\subsubsection{Whom should the board serve?}

Even though an answer to this question is not apparent from the literature (2.2), assumptions regarding whom the board should serve are important; indeed, they underpin the significant theories in governance literature. For example, both stakeholder theory and shareholder theory are based on different assumptions over whom the board should serve. Shareholder advocates such as Friedman (1962), and more recently Macey (2008), are firmly of the view that the purpose of the board is to 
serve the shareholders, while stakeholder advocates such as Cadbury (2002) hold the view that the board should serve the company, which in turn takes into account all stakeholder interests.

The results of the survey suggest that both directors and shareholders are divided in their views on this question, with approximately half of each group believing that boards should be responsible to shareholders and half believing the board is responsible to either all stakeholders or to the company itself (Figure 13, p. 193). A possible explanation for this split is suggested by the contingent nature of corporate governance, as the nature and distribution of shareholders may influence both directors' and shareholders' views on the board's responsibilities. For example, the shareholders and directors of a company with an active founder who is also the majority shareholder may well have a different view concerning who the board should serve, to the directors and shareholders of a company with no cornerstone shareholder. This contingent aspect to corporate governance will be discussed in more detail in section 8.3.7.

\subsubsection{The role of the board}

To determine the role of the board the directors and shareholders surveyed were asked to select from six possible roles (Figure 14, p. 194). Of the respondents, 54\% of directors and 59\% of shareholders considered that the role of the board is to set strategy and lead the company. The remainder of the shareholders and directors surveyed were divided among the remaining five roles. This diversity is reflected, in part, in the diversity of definitions of the responsibilities of the board outlined in Table 2 (p. 104). For example, 'setting strategy' and 'leading the company' are similar to the definitions proposed by Moltz (1985) and Cadbury (1992), and 'ensuring management keeps its promises to shareholders', another of the options, is advocated by Macey (2011).

Shareholders and directors were also queried on the specific tasks they expected a board to perform, and from this data a more nuanced picture emerges. Almost all directors and shareholders 
expect the board to perform the reactive tasks associated with monitoring and control, such as overseeing the work of auditors, replacing the CEO, and reviewing and guiding risk policy; and over $80 \%$ of directors believe that the board should set strategy. Where opinions are most divided is over the role the board should play in conducting more operationally oriented tasks, such as setting annual budgets, ensuring clear lines of accountability throughout the organisation, and replacing senior executives (Figure 15, p. 196).

This analysis suggests that there is some broad agreement among directors and shareholders on the overall role of the board, although different emphases are placed on the various aspects of the board role. Some directors appear to adopt a proactive 'hands on' approach, emphasising strategy development, while others appear to prefer a hands-off approach that favours monitoring and control. It is also apparent that the 'line' between governance and management is blurred. It is possible that these differences of opinion are influenced by the environmental conditions of the companies they govern and hence by the contingent nature of corporate governance. For example, the role that directors expect a board to perform may be influenced by factors such as the influence exerted by large shareholders, the abilities or otherwise of the management team, and the financial circumstances in which the organisation happens to find itself at the time.

\subsubsection{The tasks a board should perform}

The directors and shareholders surveyed were asked whether management or the board should perform certain tasks; a summary of their responses is presented in Figure 15 (p. 196). The data collected suggest that directors and shareholders are divided in their views over who should set company performance objectives and annual budgets, and who should be responsible for ensuring that company financial and legal obligations are met. 
The setting of goals and objectives is an important tool for achieving organisational control (Latham \& Yukl, 1975), so differing opinions over responsibility suggest that directors have differing views on the degree to which the board should actively direct the company and the degree to which it should act as a monitor of management's performance. Some definitions of governance imply that the board should actively direct the company (Cadbury, 1992; Ong \& Wan, 2008), while others play down these aspects and encourage boards to be more reactive and emphasise monitoring management (Shleifer \& Vishny, 1996; Monks, 2001; OECD, 2004; Macey, 2008). So it appears likely that the views of New Zealand shareholders and directors are equally diverse.

The results of the survey also highlight the degree to which directors are prepared to delegate legal and financial responsibilities to management. Forty-four per cent of directors are prepared to delegate to management responsibility for their company meeting its financial obligations. This is consistent with the earlier findings of Ingley \& Van der Walt (2004); they conducted their research before the GFC and the legislative changes that followed it (4.1), so it can be concluded that these events and the subsequent publicity have not substantially changed NZ public company directors' behaviour in this respect. Fifty-two per cent of directors believe that they should delegate to management the task of ensuring a company meets its legal obligations. Directors have both statutory and NZX obligations to perform certain duties themselves. Given the potential impact on directors personally of a company failing to meet some of its financial or legal obligations, this finding may suggest that either these directors do not appreciate their legal obligations or that they have a high degree of confidence in management's ability to perform these tasks.

An attempt was made to segment directors based on their views of governance. The objective was to identify clusters of directors who shared broadly similar views regarding the major issues that the survey addressed - i.e. the role of the board, the tasks that a board should perform, and to whom the board is responsible. An analysis of the survey data failed to identify any 
significant clusters. For example, the $54 \%$ of directors who believe that the role of the board is to set strategy and lead the company do not hold similar views regarding who should set annual budgets and performance targets, or to whom the board is responsible. This illustrates the diversity of views that exists within the directors surveyed - and the complex nature of this population.

\subsubsection{Boards' communication to shareholders}

One of the few obligations enshrined in law is the requirement of the board to communicate with shareholders through annual reports and annual shareholder meetings. Directors and shareholders were surveyed on their opinions regarding how well companies communicate with shareholders. Figure 17 (p. 203) shows that over $88 \%$ of the directors and shareholders who responded are happy with the overall quality of communication. This result is slightly at odds with data from the ASM analysis, which suggests that private shareholders find some of the data contained within the financial statements to be overly complex or difficult to interpret. Twenty per cent of the questions asked by shareholders at ASMs were related to reporting (Figure 9, p.174) and the answers to almost all of these questions were contained within the company financial statements, which suggests that financial statements are not meeting all shareholders' expectations.

\subsubsection{Director remuneration}

Director remuneration appears to be one of the areas where the gap between directors' and shareholders' expectations of boards is the greatest. As Figure 11 (p. 192) shows, most of the directors surveyed believe they are under-remunerated, but most shareholders surveyed disagree. This disagreement can sometimes manifest itself at company ASMs. Figure 9 (p.174) shows that $8 \%$ of the questions asked at the ASMs whose minutes were analysed related to director remuneration. 
A contributing factor to this gap may be the differing perceptions that directors and shareholders appear to hold regarding the workload of directors. Figure 15 (p.196) suggests overall that directors perform, or believe that they should perform, more governance tasks than shareholders assume they perform. That shareholders underestimate the workload of directors was also apparent in comments made by some shareholder focus group members - such as, 'these directors, they get their $\$ 50,000$ for attending a few meetings'. Another possible contributory factor is that directors may not believe they are being adequately compensated for the risk associated with the role, as discussed in section 4.1 - although there is a trend towards directors being held more accountable for their actions (Maume \& Walker, 2013). However, this factor was not tested in the research.

\subsubsection{Director and shareholder heterogeneity}

This section examines degrees of heterogeneity in shareholders' and directors' expectations of boards. Overall, the more aligned the expectations are, the more efficiently corporate governance is likely to function.

An indication of the degree of heterogeneity that exists within the director and shareholder populations can be determined by considering the degree of spread amongst the respondents' answers to the survey questions discussed in Chapter 7. Most of the data collected in the survey questions uses nominal data so in order to test the degree of diversity or spread within this data the Variation Ratio (Vr) was calculated (Weisberg, 1992 pp. 46-77). The Variation Ratio is defined as $V r=1-\left(\frac{f m o d e}{N}\right)$ where $f$ mode is the count of the most popular response and $N$ is the total responses. Variation ratios range between 0 and 100\%. A zero $\operatorname{Vr}$ denotes complete homogeneity (all respondents gave the same answer), whereas higher values of $V r$ indicate greater heterogeneity (Weisberg, 1992 pp. 46-77). Table 39 summarises the results. 
Table 39

Heterogeneity of directors' and shareholders' views

Variation Ratio $(V r)$

$\begin{array}{lrr} & \text { Directors } & \text { Shareholders } \\ \text { Board appointments } & 24 \% & 20 \% \\ \text { Role of women } & 37 \% & 23 \% \\ \text { Independent directors } & & \\ \text { Board goals } & 48 \% & 45 \% \\ \quad \text { To whom is the board responsible? } & 46 \% & 41 \% \\ \text { Role of the board } & & \\ \text { Board tasks } & 22 \% & 24 \% \\ \text { Setting company strategy } & 34 \% & 47 \% \\ \text { Setting company performance objectives } & 59 \% & 28 \% \\ \text { Setting annual budgets } & 9 \% & 10 \% \\ \text { Approving major investment expenditure } & 67 \% & 39 \% \\ \text { Ensuring clear lines of accountability throughout the organisation } & 2 \% & 6 \% \\ \text { Where necessary replace CEO } & 12 \% & 38 \% \\ \text { Where necessary replace senior executives } & 34 \% & 22 \% \\ \text { Setting occupational health and safety policy } & 52 \% & 53 \% \\ \text { Ensuring the company complies with its legal obligations } & 49 \% & 49 \% \\ \text { Ensuring the company meets its financial obligations } & 23 \% & 44 \% \\ \text { Overseeing the work of the auditors } & 17 \% & 44 \% \\ \text { Reviewing and guiding risk policy } & 20 \% & 24 \% \\ \text { Reporting to shareholders } & 13 \% & 12 \% \\ \text { Communicating with external stakeholders } & 8 \% & 32 \% \\ \text { Approving related party transactions } & \end{array}$

Some of the data is based on an ordinal scale; in these cases standard deviations have been calculated to show the degree of diversity among shareholders' and directors' view. This is shown in the following table: 


\section{Table 40}

Heterogeneity of directors' and shareholders' views continued

\begin{tabular}{lrrrr} 
& \multicolumn{2}{c}{ Directors } & \multicolumn{2}{c}{ Shareholders } \\
& mean & std dev & Mean & std dev \\
\hline How well do companies communicate with shareholders? & 3.597 & 0.876 & 3.693 & 0.996 \\
Level of director remuneration & 2.413 & 0.897 & 3.925 & 1.095
\end{tabular}

Tables 39 and 40 suggest that among the group of directors who responded to the survey a moderate degree of heterogeneity exists regarding most of these aspects of governance. Among the directors surveyed, the areas with least heterogeneity are: for approving major capital expenditure, approving related party transactions, and replacing the CEO when required. The survey showed that among shareholders the only factors with equally low heterogeneity are: approving major capital expenditure, and replacing the CEO when required. On all other aspects of corporate governance the opinions of the directors and shareholders surveyed appear to be divided.

Table 39 (p.231) also suggests that the greatest diversity in the views and expectations of directors concerns: setting annual budgets, ensuring companies meet their financial and legal obligations, and ensuring clear lines of accountability throughout the organisation. The extent to which these differences could impede the functioning of boards is likely to be determined by the degree of heterogeneity which exists within individual boards, but this has not been evaluated, given that (as stated in section 3.5.4) the decision was made not to ask directors about their company affiliations.

One plausible explanation for this high degree of heterogeneity is that directors' and shareholders' expectations of boards may in part be influenced by environmental factors and the contingent nature of corporate governance; this issue will be discussed in the following section. 


\subsubsection{The dynamic nature of board and shareholder expectations}

While the contingent and dynamic nature of corporate governance has been identified in the literature (Huse, 2005; Long, 2006), it is not an aspect of governance that commands much attention, as Gabrielsson and Huse (2004) have noted. However, in the course of this research both the dynamism and the contingent nature of governance were recurring themes that, as has been shown, were raised unprompted in the shareholder and director focus groups, in the questions asked by shareholders at ASMs, and in comments made in the director and shareholder surveys.

This research suggests that directors' expectations of boards are dynamic and can be contingent on environmental factors. Two such environmental factors have specifically been identified: the financial state of the company, and political and social pressure from outside of the company. Table 37 (p.201) suggests that in response to a financial crisis, directors assume more responsibility for tactical activities, that they would at other times delegate to management, and that, in response to social and political pressures, directors appear to be influencing the appointing of more female independent directors (4.5.4).

There are also suggestions that this dynamism and contingency may extend to other fundamental issues, such as whom the board should serve, and the nature of its purpose. A quote from the director focus group hints at this: 'Shareholders are important but sometimes they are not as important as customers.' (5.1) The research also hints that shareholders change their expectations of boards depending on circumstances. For example, shareholders at the focus group expressed the view that success is a function of management, but failure is the fault of governance (5.2.2).

\subsection{Summary}

The research has examined the expectations that New Zealand shareholders and directors have of New Zealand public company boards. The overarching theme to emerge from this examination is 
that the opinions of both shareholders and directors are divided over many of the key aspects of corporate governance. There appears to be no broad consensus on whom the board is responsible to (7.5), the role of the board (7.6), the tasks a board should perform (7.7), and board composition (7.9). When comparing the views of directors to those of shareholders it appears that both groups are divided in their views along broadly similar lines. However, there are some differences between the two groups, and these groups may either cause friction between them, as is the case with their views on director remuneration (8.3.6), or potentially impair company performance, as is the case with their views on independent directors (8.2.6). Overall, however, the research suggests shareholders are generally happy with board performance (Figure 10, p. 188) and that directors believe their companies are performing well and meeting shareholder expectations (Figure 12, p. 188).

The research also suggests that New Zealand directors' and shareholders' expectations of boards are influenced by the environment in which corporate governance is practised. The New Zealand corporate governance environment is characterised by a light-handed legal framework (4.1), few hostile takeovers of public companies, and little shareholder activism (Bhabra, 2007); all of these factors afford New Zealand directors a degree of freedom that is not necessarily shared by their overseas counterparts. In many NZSX companies institutional investors are the largest shareholder (Figure 3, p. 110); however, these investors also appear to have less influence on boards than institutional investors elsewhere (Chui \& Monin, 2003). Social issues may also influence director and shareholder expectations, and may account for the increasing participation of women on NZX-listed company boards (Figure 12, p. 190).

Variations and fluctuations that occur across the governance environment may contribute to the heterogeneity identified in both directors' and shareholders' expectations of boards. For example, while institutional investors are seldom directly involved in corporate governance (Chiu \& Monin, 2003), there are exceptions, and institutional investors have been appointed to boards 
(4.4.2). It is possible this creates differing expectations between directors. Evidence was also found that company-specific environmental factors can also influence shareholders' and directors' expectations of boards. Data collected from the shareholder and director surveys suggests that some of their expectations change when a company is trading under financial stress (Table 45, p. 295). In the following chapter the implications of these findings are examined. 


\section{SUMMARY AND CONTRIBUTIONS}

This research has contributed the extant body of corporate governance knowledge by contributing to an understanding of the characteristics of New Zealand shareholders and directors and the diversity that exists in their expectations of boards and governance. It has also highlighted the influence of the environment on aspects of corporate governance in New Zealand. In this chapter these findings are summarised and their implications are discussed. The findings have implications for future research, in terms of research design and for the application of common corporate governance theories. The findings also have implications for policy, specifically regarding investor confidence, corporate governance best practices and the comply or explain doctrine. The limitations of the research are also detailed in this chapter, as are some suggestions for future research.

\subsection{Key findings and their contribution to the extant literature}

The research informs the body of corporate governance knowledge by providing a more complete understanding of the characteristics and motivations of New Zealand shareholders and directors than has previously been discussed in the literature. It finds that within these groups there appears to be significant heterogeneity concerning many aspects of corporate governance. It also finds evidence which suggests that this heterogeneity may be influenced by certain environmental factors - and that, as these factors change, so, too, do directors' and shareholders' expectations and behaviours. This section will discuss these contributions. 


\subsubsection{Contribution to an understanding of the characteristics of New Zealand shareholders, directors and companies}

By drawing on data from multiple independent sources the research has developed a more comprehensive and up-to-date understanding of three of the key elements influencing corporate governance in New Zealand: shareholders, directors, and the companies they govern. Although private shareholders play an essential role in the overall governance process, to the author's knowledge this is the only research that has explored New Zealand private shareholders from either an attitudinal or a demographic perspective. Directors have previously been the subject of much research, and in recent years this has included demographic research (Boyle \& Ji, 2011) and some attitudinal research (Ingley \& Van der Walt, 2005). However, much has changed in the New Zealand corporate governance environment since Boyle and Ji and Ingley and Van der Walt's research studies were conducted including the global financial crisis and its subsequent fallout, the FMA has been established and the courts have started calling to account recalcitrant directors. This research updates much of this earlier work so that the impact of these and other recent events can be considered and long-term trends can be inferred.

One such trend, which arguably influences the effectiveness of New Zealand's public companies, is the apparent increase in the number of boards with a majority of independent directors. Equally importantly, this research also extends our understanding of directors by investigating previously unexplored characteristics including the human capital they contribute, their country of domicile, and 'busy' directors. The research shows that most directors have experience either in senior finance roles or as CEOs and that there is significant international influence with most New Zealand directors having international experience and a significant minority are domiciled overseas. The relationship between New Zealand public company shareholders and directors is another area that, to the author's knowledge, is researched for the first time in this thesis and the research highlights areas of potential conflict such as director remuneration. Not only does the research provide a more complete insight into the nature of New 
Zealand shareholders and directors but it also highlights some important long-term trends in these groups.

The degrees to which the control of companies is concentrated and overall shareholding is dispersed have long been acknowledged to influence corporate governance practices (Berle \& Means, 1932). The NZSX is a dynamic market in which companies periodically enter and depart and company ownership profiles change; therefore any assumptions made about control of companies and ownership dispersion must be regularly reviewed to ensure any research based upon them remains current. This research provides a more comprehensive and up-to date snapshot of New Zealand companies and their ownership than has hitherto existed. Most significantly, it provides new insights into the control of New Zealand companies and the influence of major shareholders. Its findings suggest that control and ownership of major companies has dispersed since the 1990s when La Porta et al. (1999) conducted their seminal work in this area. This research suggests that although ownership of NZSX-listed companies appears highly concentrated, with 2\% of shareholders owning $50 \%$ or more of the shares in most companies, control appears more widely dispersed. Using a $20 \%$ shareholding as a threshold for control, two-thirds of the companies analysed did not have a controlling shareholder. Given that a controlling shareholder can be a major influence over boards, this is a significant finding.

It has long been acknowledged that country-specific environmental factors influence the practice of corporate governance (Davies \& Schlitzer, 2008; Agarwal et al, 2007). However, the factors which influence the practice of corporate governance in New Zealand had not previously been identified or researched. This research makes a contribution to filling this gap by highlighting some environmental factors that appear to differentiate New Zealand governance practices. This includes elements of the legal environment, the relative influence of shareholders on boards, and the influence of independent directors, all of which have been shown to influence board behaviour particularly around their approach to risk (Koerniadi, Krishnamurti, \& Tourani-Rad, 2014). 


\subsubsection{Acknowledgement of the diversity that exists in shareholders' and directors' expectations of}

boards and of governance

The research suggests that most directors agree boards should perform some monitoring and reporting tasks. Beyond this somewhat limited scope there appears to be no broad consensus regarding other aspects of governance, including the tasks that a board should perform and the composition of the board. Shareholders, like directors, appear similarly divided in their opinions. This situation appears to reflect the current state of the corporate governance literature, which, in many respects, is also divided (Petrovic, 2008; Lipton \& Lorsch, 1992). Because of the heterogeneity within stakeholder groups, the research did not find evidence that their views support any particular theory, philosophical approach to governance, or key governance definition. In this respect the findings support the observations of Huse (1998), Aguilera et al. (2008), Heracleous (2001) and others, that directors frequently take a contingent approach to corporate governance. This research also suggests that, to the extent that shareholders participate in corporate governance, they take an equally pragmatic approach.

\subsubsection{Highlighting the influence of environment on corporate governance}

The research suggests that corporate governance practices can be contingent on the broader environment in which a company is operating and that as this environment changes, so, too, can directors' actions and expectations of boards. Both macro-environmental factors, such as economic conditions and social trends, which influence the entire market, as well as micro-economic factors such as share distribution, which influence individual companies, appear to influence director and shareholder expectations of boards. For example, the research found strong evidence to suggest that some directors' expectations of the tasks a board should perform change when a company is in financial stress - essentially these directors believe that they should become more 'hands-on' . The 
research also suggests that the trend for increasing numbers of women on boards is likely the result of external environmental factors such as interventions by external lobby groups. Other factors, such as the size and nature of large shareholders, may also influence board behaviour and hence both shareholders' and directors' expectations of boards. These findings support the framework proposed by Huse (2005), which incorporates external environmental factors alongside internal company-specific factors to explain board behaviour.

\subsection{Implications for Future Research}

The findings have implications for future research as they suggest enhancements that could be made to improve research design in future studies, and they also suggest that changes could be made to increase the validity of research incorporating some of the popular governance theories. These implications will be discussed in this section.

\subsubsection{Implications for research design}

There are many research initiatives that look to find a link between an aspect of corporate governance and overall company performance. A challenge with much of this research is that it fails to elicit repeatable results across multiple studies (Brickley \& Zimmerman, 2010). This lack of consistency and replicability has, in part, been attributed to limitations with the 'black box' style research methodology that is frequently applied to governance questions (Finkelstein \& Mooney, 2003; Gabrielsson \& Huse, 2004). The limitation of the black box approach is further exacerbated in the New Zealand context because multiple research studies are seldom conducted on the same topic, meaning that meta-analysis of multiple studies, which could potentially overcome some of these limitations (Wolf, 1986), is not generally possible. Although the limitations of black-box research have been acknowledged for more than a decade, much of the corporate governance 
research recently published using New Zealand data still relies heavily on this methodology, for example Boone et al. (2011), Fauzi \& Locke (2012), and Reddy et al. (2015). This is possibly because the influence of external environmental factors on governance within the New Zealand environment have not been fully appreciated. For example, this research suggests that the increasing number of women appointed to boards can be attributed to broader environmental factors rather than to the aspirations of directors and shareholders.

To help mitigate the limitations of the traditional methodology, this research adopted a methodology that enhanced the black-box model in two important ways. Firstly, it lifted the 'lid' on the black box by obtaining data directly from some of the principal proponents, and secondly it took cognizance of the broader economic environment in which corporate governance functions. While these enhancements added a degree of complexity to the research, the richness of the accrued data suggests that such an approach is worthy of consideration for future research.

\subsubsection{Reflections on popular corporate governance theories}

This section discusses how the insights gained in this research can assist with the application of the common corporate governance theories when applied in a New Zealand context. The theories discussed are agency theory, stewardship theory, stakeholder theory and shareholder theory.

Agency theory is the most frequently used empirical theory to explain corporate governance behaviours in the New Zealand context, for example Koerniadi \& Tourani-Rad (2012) and Hossain, Prevost \& Rao (2001). As discussed in section 2.2, agency theory assumes that a notional contract exists between directors and shareholders and that both groups are motivated by self-interest, bounded rationality and risk aversion (Jensen \& Meckling, 1976). Stewardship theory is based on the same underlying premise of a notional contract between shareholders and directors but it makes different assumptions regarding director and shareholder motivations (Davis, Schoorman \& 
Donaldson, 1977). The notional contracts between directors and shareholders are therefore an essential prerequisite for both of these theories so in situations where such explicit contracts don't exist then the theory should be applied with caution.

The heterogeneity that both directors and shareholders appear to exhibit suggests that, in many circumstances, the notional contracts that are central to agency theory and stewardship theory are unlikely to exist in many NZSX-listed companies. Evidence that supports this assertion is founded on the Companies Act requirement for directors to act in the best interests of the company (Companies Act 1993, p. 113). As has been shown in this research a company's best interests may not always align with those of shareholders. When company and shareholder interests diverge a directors legal obligations would over-ride any notional director - shareholder contracts. The research also suggests that both directors and shareholders allegiances are divided between those who believe that a board's primary obligation is to its shareholders and those who believe that the board's primary obligation is to either the company or all stakeholders (Figure 13 p.193). If a board believes that it is obligated to all stakeholders then a notional contract that places shareholders in a principle position could not exist. There is also evidence which suggests that not all shareholders appear to consider that they have entered into a notional contract with directors. For example there is evidence of rationale apathy amongst shareholders (6.4) and a suggestion from the focus group interviews that some shareholders do not believe that they have a responsibility or obligation to the company (5.3), both of these factors effectively preclude any notional contracts between shareholders and boards. Collectively these findings suggest that neither agency theory nor stewardship theory can be used to analyse New Zealand governance without first establishing that a perceived notional contract exists between directors and shareholders.

Turning now to shareholder theory and stakeholder theory, essentially these two theories describe different philosophical approaches to operating all aspects businesses including the 
functions performed by boards. Stakeholder theory advocates argue that companies exist not only for the benefit of shareholders but for the benefit of all parties who have a stake in the organisation (Jensen, 2001). Shareholder theory assumes that the purpose of governance is to serve shareholders (Friedman 1962 p.112). In many ways Shareholder theory is the reverse of stakeholder theory, so arguments that support Stakeholder theory can be arguments against Shareholder theory.

The research suggests that both company directors and shareholders are divided between stakeholder advocates and shareholder advocates. When asked directly, the shareholders and directors surveyed appeared to be evenly split between the two camps (Figure 13 p.193). Other evidence from this survey suggests that opinions may vary depending on the circumstances. For example, the survey respondents were asked if a company with excess cash would be more likely to increase dividends or invest in staff. Some $90 \%$ of directors and $77 \%$ of the shareholders surveyed indicated that they believed that a company would increase its dividends rather than invest in staff. Although this is a crude measure, it suggests that in this situation at least, most directors and shareholders expect companies adopt a shareholder centric model of governance. Conversely company law mandates that directors place the interests of the company itself at the fore (Companies Act 1993, p113) which implies that directors are legally obliged to consider a stakeholder focus. These conflicting influences suggest that the New Zealand environment is sufficiently complex and nuanced that neither theory can be universally applied across all NZX companies.

One conclusion reached from this research then is that New Zealand shareholders and directors motivations are so diverse that they do not always meet the prerequisites required of each of the four corporate governance theories discussed. This raises particular problems when attempts are made to use these theories to make assumptions regarding all New Zealand companies. It does not however, preclude the use of these theories when considering companies or groups of 
companies provided it can be established that the motivations of shareholders and directors are broadly aligned.

In many circumstances it may be possible to infer a sufficient understanding of director and shareholder motivations to allow one or more of these corporate governance theories to be applied. To illustrate this point Table 41 shows four stylised companies, each with a different ownership structure. By considering this factor alone it is possible to make assumptions regarding the motivations of shareholders and directors. Such assumptions may well be sufficient to identify those corporate governance theories whose prerequisites are met and therefore could be more confidently applied.

\title{
Table 41
}

Matching corporate governance theory to ownership structure

\begin{tabular}{l} 
Ownership \\
Structure \\
\hline $\begin{array}{l}\text { Private equity firm } \\
\text { owns a } 51 \% \text { stake }\end{array}$ \\
Long-standing MD \\
with a small stake \\
and no other \\
dominant shareholder \\
Government entity \\
with a majority stake \\
Large financial \\
institution with a \\
minority stake. No \\
other major investors
\end{tabular}

Implications
Directors and the shareholder will be aware of an implicit age
contract between them. The shareholder is likely to take a longer
term pragmatic approach to the business and is likely to be
actively involved in governance through the appointment of
inside directors.

Suggested Theory

The MD is unlikely to be motivated by short term financial gain and is likely to put the company first.

\author{
Agency \\ theory
}

Stewardship theory
Shareholders and directors are likely to follow the companies act and prioritise all stakeholders.
The financial institution is likely to be focused on short/medium term shareholder value and the independent directors, mindful of the institution's influence over their careers as directors are likely to follow the institutions example.

Stakeholder theory Shareholder theory

Of course the assumptions made regarding the behaviour of directors and shareholders may not apply to every company with these ownership structures - other factors, such as an impending takeover threat may sometimes over-ride these assumptions. The key points that the table further 
illustrates is that the corporate governance theories discussed cannot be applied carte blanche but if consideration is given to environmental factors then it is likely that a corporate governance theory can be identified that can realistically be applied.

The concept that corporate governance is context sensitive has been mooted by Aguilera et al (2008) and Huse (2005). However neither author has discussed the implication of this concept to the application of corporate governance theories. Ingley, Mueller and Cocks (2011) have suggested that the heterogeneity found within New Zealand directors groups suggests that a multi-theoretical approach may often be required in order to adequately capture the complexity of corporate governance and the board's role, this research supports this view and suggests how this might be applied in practice.

\subsection{Policy Implications}

The issues that the research informs from a policy perspective include investor confidence in capital markets, the underlying approach to regulation, and corporate governance best practices. The findings have potential implications for policy makers and educators associated with corporate governance. This a group which includes the NZX, the FMA, the NZIoD and the Shareholders' Association as well as government.

\subsubsection{Improving investor confidence in boards}

When investors have trust and confidence in public companies they will arguably be more inclined to invest in the stock market. Given that a vibrant and dynamic stock market leads to a stronger economy, there is a strong incentive to ensure that potential investors, small and large, have sufficient trust and confidence to actively invest in equities (Gourevitch \& Shinn, 2009). Boards, as 
a perceived bridge between shareholders and companies, can play a key role in building this trust and confidence.

This research suggests that although shareholder satisfaction with boards and their directors is reasonably high, some shareholders have concerns about directors and governance. Few shareholders appear to actively participate in the governance process and many do not consider directors to be 'value for money'. Equally concerning was the survey result suggesting that in time of financial crisis some shareholders consider that directors will put their own interests above those of the company or shareholders. The FMA, with its mandate to ensure public confidence in financial markets, is responsible for addressing these shareholder concerns. There is also a role for organisations such as the NZIoD, the NZX and the Shareholders' Association to increase their education programmes for directors.

\subsubsection{Maintaining a 'comply or explain' approach to regulation}

Overall, New Zealand directors appear to be a well-qualified and experienced group, as most appear to have extensive, relevant commercial experience prior to joining boards. That directors appear to adopt different views and approaches to most aspects of corporate governance strongly suggests that there is no perceived single 'right way' to approach corporate governance. This has significant implications for policy makers as it suggests that a highly prescriptive approach to rules and regulations may not always deliver the best possible outcomes from either a shareholders or a directors perspective. This is because a rules-based approach potentially limits the flexibility of boards. Cadbury (2002), reaching a similar conclusion when considering governance practices in the UK, recommended that governance regulation should be based on a 'comply or explain' doctrine wherever practicable, rather than a highly prescriptive rules-based approach. The NZX has largely adopted a comply or explain approach to regulation and the findings suggest that its 
implementation is essentially 'on-track' - although some rules, such as NZX rule 3.3.1c, which mandates that a minimum of two independent directors be appointed to each board, are arguably unnecessarily prescriptive and could be reviewed in light of these findings.

\subsubsection{Corporate governance best practices}

The findings also call into question the application of 'best practices' in the NZX environment. Splitting the role of CEO and chairman and including independent directors on boards are regarded as best practices in New Zealand, but linking them to company performance is tenuous at best, according to many researchers. Supporters of these practices have dismissed criticism by pointing to limitations in the research (Dalton et al, 2003). However, the diversity identified in this research supports an argument proffered (but not substantiated) by Heracleous (2001), that the reason best practices are not seen to improve either governance or company performance is because different types of organisations require different practices. This research therefore suggests that shareholders, directors and lobby groups would all benefit from acknowledging that best practice prescriptions are best treated as guidelines and that it is not necessarily in every company's best interests to blindingly implement all such recommendations.

\subsection{Limitations of the Study}

The key limitations of this research were a lack of access to institutional investors, limitations on the sample size of the public company research, an inability to associate companies with directors, a limit on the number of ASM minutes analysed and restrictions on the environmental factors investigated.

Direct access to institutional investors was not achieved. The CEOs of some of New Zealand's largest institutional investment firms were invited to participate in this research and all 
declined. This limitation was addressed, in part, by analysing institutional investor behaviour and by drawing on the limited available literature. Given the unique position that institutional investors hold in the market their participation would add a useful additional perspective to any future research conducted in this area. The data on company ownership distribution, control and other metrics were collected from 40 of the 112 NZSX companies. The sample was restricted to 40 companies due to time constraints. While this analysis is sufficient to support the conclusions drawn in this study, an analysis of all 112 companies may have yielded further insights.

An inability to associate surveyed directors with their companies also proved to be a lost opportunity with the research. Given company directors' well-known reluctance to discuss their affairs (Leblanc \& Schwartz, 2007), the postal surveys were made as anonymous as possible. As a result, insufficient data was obtained to determine the degree of heterogeneity that exists within individual company boards. Had such data been forthcoming it would have provided deeper insights into the relationship between the environment and company behaviour, and could also have shed light on a number of related issues, such as the impact of shared directors on director homogeneity. This also provides an opportunity for future research, for example, by linking the directors to a particular company it would be possible to examine the impact of factors such as market conditions and size of largest shareholder on director expectations.

A total of 65 sets of minutes were obtained from 30 companies. Company willingness to make these available and the time required to persuade companies who were initially reluctant to release their minutes limited the number of sets of minutes that could be collected. While there was sufficient data to obtain a general picture it is possible that more data would have led to a more detailed understanding of the relationship between directors and shareholders.

There is also a limitation regarding the environmental analysis that was conducted. The research has highlighted some environment factors that have influenced shareholder and director 
expectations of boards such as the influence of lobby groups on director selection. However, the research in this area was confined to a small number of environmental factors and it is probable that other factors that were not examined in this research could also influence shareholder and director expectations. Future research in this area would provide a more complete picture of shareholder and director expectations of boards.

\subsection{Directions for Further Research}

The research has provided insights into the expectations of two of the key stakeholder groups associated with corporate governance. Another significant stakeholder group with potential to influence corporate governance is executive management. The opinions that executive managers hold of New Zealand boards and corporate governance have not previously been comprehensively canvassed. A research project that investigated their opinions and expectations of boards and used a similar structure to that adopted in this research would add to the overall picture of corporate governance within New Zealand.

The topic of governance when a firm is in crisis - financial or otherwise - is not well researched, either internationally (Daily et al, 2003) or in New Zealand. Given the importance of governance to companies in times of crisis, this is an area that requires further research. This research has provided some evidence which suggests that when companies are in financial crisis, boards are expected to change their behaviour. It also identified a number of structural changes that are occurring with New Zealand boards, such as increasing numbers of independent directors, which have the potential to influence the way companies respond to crisis. Research in this area may yield important new insights.

Further research directly into shareholder and director expectations is still warranted, as a better understanding could potentially address some of the key issues restraining corporate 
governance research. For example a better understanding of the financial expectations that shareholders and directors have of their companies could alter the financial metrics that researchers use to evaluate company performance. A better understanding of the environmental factors which influence director and shareholder expectations of boards could lead to improved research design and a better understanding of the application of common corporate governance theories.

\subsection{Influence of the Research on the Researcher.}

Just as the researcher influences the research, so the research influences the researcher. In this section I briefly discuss the impact that this research has had on my personal views and expectations of corporate governance and beyond.

When I commenced this research I was aware that the field of corporate governance is filled with dogma. However, I believed that underneath this dogma there were some central truths (maybe I was a positivist at heart). My task in part, I had decided, was to unearth these truths. During the course of the research I was shocked to discover that experienced, intelligent directors (and researchers) frequently held radically different opinions on almost every fundamental aspect of corporate governance. Surely some people were right while others were wrong - where were my fundamental truths? By the end of the research I had concluded that I was initially wrong, and there are few, if any, central truths. The different views held by directors, I've concluded, are likely a pragmatic response to the environment in which they have, at one stage or another, found themselves. This revelation, has forced me to rethink my fundamental views, not only on corporate governance, but on business as a whole. Is the purpose of a company solely to make money for shareholders? Is the purpose of the board to ensure that management keeps its promises to shareholders? My answer to these and related questions, is now very different to when I commenced this research. Companies' objectives, I now believe, are more complex than I first thought, maximising returns to shareholders is not the single underlying objective, merely one objective amongst many other equals. 
My views of directors has also changed. The days of 'typical' boards acting solely as monitors and score keepers and looking after the interests of shareholders are probably long gone. Today board are acting increasingly independent of both shareholders and management. Driven by directors' egos and legislation that, for self-preservation reasons compels them to action, they have moved beyond being referees and scorekeepers and have become players in their own right. That many boards are dominated by independent directors, with little experience of the industry in which they are operating and with no significant financial investment in the companies they govern is one emerging feature that is forcing me to question my assumption that public companies are always the best vehicle to increase the economic well-being of those in our community.

\subsection{A Last Word}

Public company boards make important decisions. Their actions can influence the success or failure of public companies; they determine how the cash flows from these companies are distributed and, in so doing, influence the prosperity of many New Zealanders. Their collective success or failure influences the willingness of investors to invest in our capital markets. Therefore, who is appointed to boards, what objectives they set, which roles and tasks they perform and how they are viewed by shareholders are all important questions that, directly or indirectly, influence the prosperity of many in our society.

This research suggests that, in general, New Zealand public company directors appear to be well-qualified and experienced. However, there also appears to be little consensus among these directors regarding many of the key aspects of corporate governance. Directors across all NZ companies are likely to be divided in their opinions on issues such as to whom the board is responsible, what the objectives of the board are, and what tasks it should perform. That 
experienced directors would be divided on such fundamental questions may, at first glance, seem surprising. However, on closer examination it appears that directors are influenced by the environment in which they operate and their company circumstances, such that on occasion they may adjust their views on the most fundamental corporate governance tenets in order to match these contingencies. New Zealand's public company shareholders, for the most part, choose not be actively involved in the governance of the companies in which they own shares. However, when questioned on matters of governance their opinions appear divided along broadly similar lines to those of directors, so their views may also be influenced by environmental and company factors. Now that we have some sense of what is expected from New Zealand's public company boards the next challenge is to work to improve them. 


\section{REFERENCES}

Accident Compensation Commission (2014) Annual Report. Retrieved 22/3/15 from

http://www.acc.co.nz/PRD_EXT_CSMP/groups/external_communications/documents/repor ts_results/annual_report_2014.pdf

Adams, R. B., \&, D. (2009). Women in the boardroom and their impact on governance and performance. Journal of Financial Economics, 94(2): 291-309. doi:10.1016/j.jfineco.2008.10.007

Adams, R. B., Hermalin, B. E. M., \& Weisbach, M. S. (2010). The role of boards of directors in corporate governance: a conceptual framework and survey. Journal of Economic Literature 48(1): 58-107.

Agarwal, A., \& Knoeber, C. R. (1996). Firm performance and mechanisms to control agency problems between managers and shareholders. Journal of Financial and Quantitative Analysis, 31(3): 377-397.

Agarwal, R., Erel, I., Stulz, R. M., \& Williamson, R. (2007). Do US firms have the best corporate governance? A cross-country examination of the relation between corporate governance and shareholder wealth. National Bureau of Economic Research.

Aguilera, R. V. (2005). Corporate governance and director accountability: an institutional comparative perspective. British Journal of Management, 16(s1): S39-S53. doi:10.1111/j.1467-8551.2005.00446.x

Aguilera, R. V., Filatochev, I. \& Jackson, G. (2008). An organisational approach to comparative corporate governance: costs, contingencies and complementarities. Organisational Science, 19(3): 475-492. 
Aguilera, R. V., \& Jackson, G. (2003). The cross-national diversity of corporate governance: dimensions and determinants. Academy of Management Review, 28(3): 447-465.

Armstrong, C., Guay, W., Weber, J. (2010). The role of information and financial reporting in corporate governance and debt contracting. Working paper, University of Pennsylvania and Massachusetts Institute of Technology, March 14.

Asbury, J. (1995). Overview of focus group research. Qualitative health research, 5(4) 414-420 November 1995.

Australian Securities Exchange ASX Australian Share Ownership Study 2012, downloaded from http://www.asx.com.au/documents/resources/asx-sos-2012.pdf

Australian Securities Exchange Corporate Governance Council (2007). Corporate Governance Principles and Recommendations (2nd edition). ASX Corporate Governance Council, Sydney.

Bainbridge, S. M. (2008). Remarks on say on pay: An unjustified incursion on director authority. Law and Economics Research Paper Series, Research Paper 08-06, UCLA School of Law.

Beatty, P. C., \& Willis, G. B. (2007). Research synthesis: the practice of cognitive interviewing. Public Opinion Quarterly, 71(2): 287-311. doi:10.1093/poq/nfm006

Bennedsen, M. (2014). The decline of an iconic British brand. Insead Knowledge. Downloaded 28 July 2014 from http://knowledge.insead.edu/family-business/the-decline-of-an-iconicbritish-brand-3445

Berghe, den, L. A. A. V., \& Baelden, T. (2005). The complex relation between director independence and board effectiveness. Corporate Governance, 5(5): 58-83. doi:10.1108/14720700510630068 
Berle, A. B., \& Means, G. C. (1932). The Modern Corporation \& Private Property. Reprint (2010), Transaction Publishers, New Jersey.

Bhabra, G. S. (2007). Insider ownership and firm value in New Zealand. Journal of Multinational Financial Management, 17(2): 142-154. http://doi.org/10.1016/j.mulfin.2006.08.001

Bhagat, S., \& Black, B. (1998). Board independence and long-term performance. Columbia Law School, Centre for Law and Economics Studies, Working Paper 143.

Blake, A. (1999). Dynamic directors: aligning board structure for business success. Macmillan, Basingstoke.

Bond, G. (2012) Capital + Merchant Finance directors jailed The National Business Review. (n.d.). Retrieved January 2, 2016, from http://www.nbr.co.nz/article/capital-merchant-financedirectors-jailed-gb-127349

Boone, A. L., Casares Field, L., Karpoff, J. M., \& Raheja, C. G. (2007). The determinants of corporate board size and composition: an empirical analysis. Journal of Financial Economics, 85(1): 66-101. http://doi.org/10.1016/j.jfineco.2006.05.004

Boone, N., Colombage, S., \& Gunasekarage, A. (2011). Block shareholder identity and firm performance in New Zealand. Pacific Accounting Review, 23(2): 185-210. doi:10.1108/01140581111163999

Boyd, B. K. (1994). Board control and CEO compensation. Strategic Management Journal, 15(5): 335-344. http://doi.org/10.1002/smj.4250150502

Boyd, B. K. (1995). CEO duality and firm performance: a contingency model. Strategic Management Journal, 16(4): 301-312. 
Boyer, R. (2005). From shareholder value to CEO power: the paradox of the 1990s. Competition and Change, 9(1): 7-47. doi:10.1179/102452905X38623

Boyle, G., \& Ji, X. J. (2011). New Zealand corporate boards in transition: composition, activity and incentives between 1995 and 2010. Working Papers in Economics. Retrieved 1 July 2012 from http://www.nzfc.ac.nz/archives/2012/papers/updated/14.pdf

Bradbury, M., \& Zijl, T. (2006). Due process and the adoption of IFRS in New Zealand. Australian Accounting Review, 16(39): 86-94.

Branson, D. M. (2011). Initiatives to place women on corporate boards of directors - a global snapshot. Journal of Corporation Law, 37(4): 793.

Brickley, J. A., \& Zimmerman, J. L. (2010). Corporate governance myths: comments on Armstrong, Guay, and Weber. Journal of Accounting and Economics, 50(2-3): 235-245. doi:10.1016/j.jacceco.2010.10.002

Bridges, S. (2014). Health and Safety Reform Bill Government Bill 192-1. Retrieved 20/1/15 from http://www.legislation.govt.nz/bill/government/2014/0192/latest/DLM5976660.html

Briggs, P. (2012). Financial accounts and flow of funds. Reserve Bank of New Zealand Bulletin. (75)4: 26-35.

Brown, L. D., \& Caylor, M. L. (2004). Corporate governance study: the correlation between corporate governance and company performance. Corporate Governance Study, Institutional Shareholder Services.

Brudney, V. (1982). The independent director: heavenly city or Potemkin Village? Harvard Law Review, 95(3): 597-659. doi:10.2307/13405 
Burgess, Z., \& Tharenou, P. (2002). Women board directors: characteristics of the few. Journal of Business Ethics, 37(1): 39-49.

Burke, R. J. (2003). Women on corporate boards of directors: the timing is right. Women in Management Review, 18(7): 346-348. doi:10.1108/09649420310498966

Business Day (n.d.). Push to get more women on boards. Retrieved 17/2/15 from http://www.stuff.co.nz/business/industries/7091570/Push-to-get-more-women-on-boards

Cadbury, A. (1992). Report of the Committee on the Financial Aspects of Corporate Governance. Committee on the Financial Aspects of Corporate Governance / Gee \& Co. Ltd, London.

Cadbury, A. (2002). Corporate Governance and Chairmanship: a personal view. Oxford University Press, Oxford.

Cameron, L., (2007). Investor protection and the New Zealand stock market. New Zealand Treasury Policy Perspectives Paper 07/02.

Canavan, J., Jones, B., \& Potter, M. J. (2004). Board tenure: how long is too long? Directors and Boards (American edition), 28(2): 39-42.

Cardow, A., \& Wilson, W. R. (2015). In Lombard we trust: the value of independent celebrity directors. Retrieved from http://papers.ssrn.com/sol3/papers.cfm?abstract_id=2562565

Carter, D. A., D’Souza, F., Simkins, B. J., \& Simpson, W. G. (2010). The gender and ethnic diversity of US boards and board committees and firm financial performance: board diversity and financial performance. Corporate Governance: An International Review, 18(5): 396-414. doi:10.1111/j.1467-8683.2010.00809.x

Carter, D. A., Simkins, B. J., \& Simpson, W. G. (2003). Corporate governance, board diversity, and firm value. Financial Review, 38(1): 33-53. 
Cashman, G. D., Gillan, S. L., \& Jun, C. (2012). Going overboard? On busy directors and firm value. Journal of Banking \& Finance, 36(12): 3248-3259. http://doi.org/10.1016/j.jbankfin.2012.07.003

Catasús, B., \& Johed, G. (2007). Annual general meetings-rituals of closure or ideal speech situations? A dual analysis. Scandinavian Journal of Management, 23(2), 168-190.

Cavana, R., Delahaye, B., Sekaran, U. (2001). Applied Business Research: qualitative and quantitative methods. John Wiley \& Sons, Milton, Australia.

Cernat, L. (2014). The emerging European corporate governance model: Anglo-Saxon, Continental, or still the century of diversity? Journal of European Public Policy, 11(1): 147-166. doi:10.1080/1350176042000164343

Chahine, S., Filatotchev, I., \& Zahra, S. A. (2011). Building perceived quality of founder-involved IPO firms: founders' effects on board selection and stock market performance. Entrepreneurship Theory and Practice, 35(2): 319-335. http://doi.org/10.1111/j.15406520.2009.00361.x

Chen, K. W., \& Lee, C. (1995). Accounting measures of business performance and Tobin's q theory. Journal of Accounting, Auditing \& Finance, 10(3): 587-609.

Chhaochharia, V., \& Grinstein, Y. (2007). Corporate governance and firm value: the impact of the 2002 governance rules. Journal of Finance, 62(4): 1789-1825.

Chin, T., Vos, E., \& Quin, C. (2004). Levels of ownership structure, board composition and board size seem unimportant in New Zealand. Corporate Ownership \& Control, 2(1): 119-128.

Chiu, P., \& Monin, J. (2003). Effective corporate governance: from the perspective of New Zealand fund managers. Corporate Governance: an international review, 11(2): 123-131. 
Clarke, D. C. (2007). Three concepts of the independent director. Delaware Journal of Corporate Law, 32(1): 73-111.

Coates, J. C. (2007). The goals and promise of the Sarbanes-Oxley Act. Journal of Economic Perspectives, 21(1): 91-116.

Colmar Brunton (2013). Financial Knowledge and Behaviour Survey 2013. Prepared for the Commission for Financial Literacy and Retirement Income.

Companies Act, No. 105 (1993). Retrieved from

http://www.legislation.govt.nz/act/public/1993/0105/latest/DLM319570.html

Companies Office New Zealand Companies Register . Retrieved 22 November 2013 from http://www.business.govt.nz/companies/

Comper, T. (2001). Corporate governance: the shape of things to come. Ivey Business Journal, JulAug. 2001. Retrieved 28/5/2012 from

http://www.iveybusinessjournal.com/topics/strategy/corporate-governance-the-shape-ofgovernance-to-come.

Conyon, M., Judge, W. Q., \& Useem, M. (2011). Corporate governance and the 2008-09 financial crisis. Corporate Governance: an international review, 19(5): 399-404. doi:10.1111/j.14678683.2011.00879.x

Conyon, M. J., \& Peck, S. I. (1998). Board size and corporate performance: evidence from European countries. European Journal of Finance, 4(3): 291-304. doi:10.1080/135184798337317 
Coombs, W. T. (2007). Protecting organization reputations during a crisis: the development and application of situational crisis communication theory. Corporate Reputation Review, 10(3): 163-176. doi:10.1057/palgrave.crr.1550049

Core, J. E., Holthausen, R. W., \& Larcker, D. F. (1999). Corporate governance, chief executive officer compensation, and firm performance. Journal of Financial Economics, 51(3): 371406.

Crespí-Cladera, R., \& Pascual-Fuster, B. (2014). Does the independence of independent directors matter? Journal of Corporate Finance, 28(c): 116-134. doi:10.1016/j.jcorpfin.2013.12.009

Dahlquist, M., \& Robertsson, G. (2001). Direct foreign ownership, institutional investors, and firm characteristics. Journal of Financial Economics, 59(3): 413-440.

Daily, C. M., \& Dalton, D. R. (1994). Bankruptcy and corporate governance: the impact of board composition and structure. Academy of Management Journal, 37(6), 1603-1617. http://doi.org/10.2307/256801

Daily, C. M., Dalton, D. R., \& Canella, A. A. (2003). Corporate governance: decades of dialogue and data. Academy of Management Review, 28(3): 371-382.

Daines, R. M., Gow, I. D., \& Larcker, D. F. (2010). Rating the ratings: how good are commercial governance ratings? Journal of Financial Economics, 98(3): 439-461.

Dalton, D. R., Daily, C. M., Certo, S. T., \& Roengpitya, R. (2003). Meta-analyses of financial performance and equity: fusion or confusion? Academy of Management Journal, 46(1): 1326.

Dalton, D. R., Daily, C. M., Johnson, J. L., \& Ellstrand, A. E. (1999). Number of directors and financial performance: a meta-analysis. Academy of Management Journal, 42(6): 674-686. 
Davies, M., \& Schlitzer, B. (2008). The impracticality of an international 'one size fits all' corporate governance code of best practice. Managerial Auditing Journal, 23(6): 532-544. doi:10.1108/02686900810882093

Davis, J. H., Schoorman, F. D., \& Donaldson, L. (1997). Toward a stewardship theory of management. Academy of Management Review, 22(3): 20-47.

De Andres, P., Azofra, V., \& Lopez, F. (2005). Corporate boards in OECD countries: size, composition, functioning and effectiveness. Corporate Governance: An International Review, 13(2): 197-210.

Dobbin, F., \& Jung, J., (2010). Corporate board gender diversity and stock performance: the competence gap or institutional investor bias? North Carolina Law Review, 89: 809.

Dodd, E. M. (1932). For whom are corporate managers trustees? Harvard Law Review, 45(7): 1145. doi:10.2307/1331697

Dodge v. Ford Motor Co. (1919). Supreme Court of Michigan, 204 Mich. 459; 170 N.W. 668; 1919 Mich. LEXIS 720; 3 A.L.R. 413 April 9, 1918.

Donaldson, L. (1990). The ethereal hand: organizational economics and management theory. Academy of Management Review, 15(3): 369-381.

Donaldson, L., \& Davis, J. H. (1994). Boards and company performance - research challenges the conventional wisdom. Corporate Governance: An International Review, 2(3): 151-160.

Donaldson, T., \& Preston, L. E. (1995). The stakeholder theory of the corporation: concepts, evidence, and implications. Academy of Management Review, 20(1): 65-91.

Donker, H., \& Zahir, S. (2008). Towards an impartial and effective corporate governance rating system. Corporate Governance, 8(1): 83-93. 
Doumani, S., George, R., \& Kabir, R. (2006). Foreign and domestic ownership, business groups, and firm performance: evidence from a large emerging market. Strategic Management Journal, 27(7): 637-657. doi:10.1002/smj.535

Doyle, B., \& Cheong, A. (2011). Equity Strategy Goldman Sachs and Partners New Zealand Investment Research.

Easterby-Smith, M., Thorpe, R., Jackson, P., \& Lowe, A. (2008). Management research: Theory and practice. Sage Publications Ltd., London, UK, 101, 210

Eisenberg, T., Sundgren, S., \& Wells, M. T. (1998). Larger board size and decreasing firm value in small firms. Journal of Financial Economics, 48(1): 35-54.

Eisenhardt, K. M. (1989). Agency theory: an assessment and review. Academy of Management Review, 14(1): 57-74.

Elayan, F. A., Lau, J. S. C., \& Meyer, T. O. (2003). Executive incentive compensation schemes and their impact on corporate performance: evidence from New Zealand since compensation disclosure requirements became effective. Studies in Economics and Finance, 21(1): 54-92. http://doi.org/10.1108/eb028769

Fahlenbrach, R., Low, A., \& Stulz, R. M. (2010). Why do firms appoint CEOs as outside directors? Journal of Financial Economics, 97(1): 12-32. doi:10.1016/j.jfineco.2010.01.003

Fama, E.F., Jensen, M. C. (1983). Separation of ownership and control. Journal of Law and Economics, 26(2): 301-325.

Farrar, J. (2008). Corporate Governance: theories, principles and practice (3rd edition). Oxford University Press, Oxford. 
Fauzi, F., \& Locke, S. (2012). Board structure, ownership structure and firm performance: a study of New Zealand listed firms. Asian Academy of Management Journal of Accounting \& Finance, 8(2): 43-67.

Ferreira, M. A., \& Matos, P. (2008). The colors of investors' money: the role of institutional investors around the world. Journal of Financial Economics, 88(3): 499-533. http://doi.org/10.1016/j.jfineco.2007.07.003

Ferris, S. P., Jagannathan, M., \& Pritchard, A. C. (2003). Too busy to mind the business? Monitoring by directors with multiple board appointments. Journal of Finance, 58(3): $1087-1112$.

Ferris, S. P., Kim, K. A., Nishikawa, T., \& Unlu, E. (2011). Reaching for the stars: the appointment of celebrities to corporate boards. International Review of Economics, 58(4): 337-358. http://doi.org/10.1007/s12232-011-0139-4

Fich, E. M. (2005). Are some outside directors better than others? Evidence from director appointments by Fortune 1000 Firms. Journal of Business, 78(5): 1943-1972. doi:10.1086/431448

Fich, E. M., \& Shivdasani, A. (2006). Are busy boards effective monitors? Journal of Finance, 61(2): 689-724.

Field, L., Lowry, M., \& Mkrtchyan, A. (2013). Are busy boards detrimental? Journal of Financial Economics, 109(1): 63-82. http://doi.org/10.1016/j.jfineco.2013.02.004

Financial Markets Authority (n.d.). What we do. Retrieved 14 March 2014 from https://www.fma.govt.nz/about-us/what-we-do/ 
Financial Markets Authority (2014). Financial Markets Authority Annual Report 2014. Retrieved from http://www.fma.govt.nz/assets/Report-and-Papers/Corporate-Publications/FMAAnnual-Report-2014.pdf

Financial Reporting Council (2010). The UK corporate governance code. Financial Reporting Council, London. Retrieved from http://www.nonexecutivedirector.co.uk/images/files/UK\%20Corporate\%20Governance\%20 Code\%20September\%202012.pdf

Finkelstein, S., \& Mooney, A. C. (2003). Not the usual suspects: how to use board process to make boards better. Academy of Management Executive, 17(2): 101-113.

Forbes, D. P., \& Milliken, F. J. (1999). Cognition and corporate governance: understanding boards of directors as strategic decision-making groups. Academy of Management Review, 24(3): 489-505.

Forsyth Barr (2015). Market Equities Outlook, April 2015.

Fowler Jr., F. J. (2009). Survey Research Methods. Applied Social Research Methods Series, No. 1. Sage Publications.

Fox, M. A., Walker, G. R., \& Pekmezovic, A. (2012). Corporate governance research on New Zealand listed companies. Arizona Journal of International \& Comparative Law, 29(1): 147.

Freeman, R. E., \& Reed, D. L. (1983). Stockholders and stakeholders: a new perspective on corporate governance. California Management Review, 25(3): 88-106.

Friedman, M. (1962). Freedom and Capitalism. University of Chicago Press, Chicago. 
Gabrielsson, J., \& Huse, M. (2004). Context, behaviour, and evolution: challenges in research on boards and governance. International Studies of Management and Organization, 34(2): 1136.

Gamble, A., \& Kelly, G. (2001). Shareholder value and the stakeholder debate in the UK. Corporate Governance, 9(2): 110-117.

Garratt, B. (2004). Thin on Top: why corporate governance matters and how to measure and improve board performance (2nd edition). Nicholas Brealey Publishing, London.

Gaynor, B. (2011). Shallow pool of directors needs deepening. NZ Herald, 7/5/11. Retrieved $29 / 8 / 15$ from http://www.nzherald.co.nz/business/news/article.cfm?c id=3\&objectid=10723870

Gaynor, B., (2014) Who's on the board: a vital shareholder issue. NZ Herald, 29/11/14. Retrieved $30 / 11 / 14$ from http://www.nzherald.co.nz/business/news/article.cfm?c_id=3\&objectid=11366142

General Motors (2011). General Motors Company Board of Directors Corporate Governance Guidelines.

Georgeson (2011). Annual Corporate Governance Review 2011. Retrieved 29/6/12 from http://www.georgeson.com/usa/acgr.php.

German corporate governance code (2005). Retrieved from http://preview.dcgk.de/files/dcgk/usercontent/en/download/2013/konsultationsverfahren_20 13 02_05/German_Corporate_Governance_Code_May_15_2012.pdf

Gillan, S. L., \& Starks, L. T. (2000). Corporate governance proposals and shareholder activism: the role of institutional investors. Journal of Financial Economics, 57(2): 275-305. 
Gillman, M., \& Hogan, J. (1999). Extending corporate liability in New Zealand. International Journal of Social Economics, 26(4): 487-500.

Goldfinch, M. (2004). Do the NZX listing rules destroy value? University of Auckland Business Review, 6(1).

Gordon J. N. (2007). The rise of independent directors in the United States, 1950-2005: of shareholder value and stock market prices. Stanford Law Review, 59(6): 1465-1568.

Gourevitch, P. A., \& Shinn, J. (2009). Political Power and Corporate Control: the new global politics of corporate governance. Princeton University Press, Princeton.

Grant, D. (1997) Bulls, bears and elephants; a history of the New Zealand stock exchange. Victoria University Press

Grant, G. H. (2003). The evolution of corporate governance and its impact on modern corporate America. Management Decision, 41(9): 923-934.

Grant Thornton (2011) NZ bucks trend as proportion of women in senior management falls globally. (n.d.). Retrieved December 30, 2015, from http://www.grantthornton.co.nz/Press/2011-press-releases/nz-bucks-trend-as-proportion-ofwomen-in-senior-management-falls-globally.html

Greenbury, R. (1995). Director's remuneration report of a study group chaired by Sir Richard Greenbury. Retrieved 27/3/15 from: http://www.ecgi.org/codes/documents/greenbury.pdf

Gregory, H. J. (2008). Comparison of Corporate Governance Guidelines and Codes of Best

Practice. Weil, Gotshal and Manges, New York. Retrieved June 29, 2012, from http://www.weil.com/news/pubdetail.aspx?pub=9333 
Gregory-Smith, I. (2012). Chief Executive Pay and Remuneration Committee Independence*: Chief executive pay and remuneration committee independence. Oxford Bulletin of Economics and Statistics, 74(4), 510-531. http://doi.org/10.1111/j.1468-0084.2011.00660.x

Guest, P. M. (2009). The impact of board size on firm performance: evidence from the UK. European Journal of Finance, 15(4): 385-404.

Gupta, N. (2005). Partial privatization and firm performance. The Journal of Finance, 60(2), 9871015.

Heracleous, L. (2001). What is the impact of corporate governance on organisational performance? Corporate Governance: An International Review, 9(3): 165-173. http://doi.org/10.1111/1467-8683.00244

Herrigel, G. (2006). Paper prepared for Geoffrey Jones and Jonathan Zeitlin (eds), Handbook of Business History. Oxford University Press, Oxford. Retrieved from https://herrigel.sites.uchicago.edu/sites/herrigel.uchicago.edu/files/uploads/final_draft_cg_p aper.pdf

Higgs, D. (2003). Review of the effectiveness of non-executive directors. Department of Trade and Industry, London.

Hossain, M., Prevost, A. K., \& Rao, R. P. (2001). Corporate governance in New Zealand: the effect of the 1993 Companies Act on the relation between board composition and firm performance. Pacific-Basin Finance Journal, 9(2): 119-145.

Huang, C.-C., Watson, S., \& Chen, J. (2013). Putting 'why' before 'how': evaluating the rationales for partial privatisation of state-owned enterprises in New Zealand. Retrieved from http://papers.ssrn.com/sol3/papers.cfm?abstract_id=2228409 
Huse, M. (1998). Researching the dynamics of board shareholder relations. Long Range Planning, 31(2): 218-226.

Huse, M. (2005). Accountability and creating accountability: a framework for exploring behavioural perspectives of corporate governance. British Journal of Management, 16(s1): S65-S79. doi:10.1111/j.1467-8551.2005.00448.x

Huse, M., Hoskisson, R., Zattoni, A., \& Viganò, R. (2009). New perspectives on board research: changing the research agenda. Journal of Management \& Governance, 15(1): 5-28. doi:10.1007/s10997-009-9122-9

Ingley, C. B., Mueller, J., \& Cocks, G. (2011). The financial crisis, investor activists and corporate strategy: will this mean shareholders in the boardroom? Journal of Management \& Governance, 15(4), 557-587. doi:10.1007/s10997-010-9130-9

Ingley, C. B., \& Van der Walt, N. T. (2002). Board dynamics and the politics of appraisal. Corporate Governance: An International Review, 10(3): 163-174.

Ingley, C. B., \& Van der Walt, N. T. (2004). Corporate governance, institutional investors and conflicts of interest. Corporate Governance: An International Review, 12(4): 534-551.

Ingley, C. B., \& Van der Walt, N. T. (2005). Do board processes influence director and board performance? Statutory and performance implications. Corporate Governance: An International Review, 13(5): 632-653.

Institute of Chartered Accountants Worldwide. When is comply or explain the right approach? (n.d.). Retrieved 19/6/15 from http://www.icaew.com/ /media/corporate/files/technical/corporate\%20governance/dialogue \%20in\%20corporate\%20governance/icaew\%20t1\%20q3\%20web.ashx 
Institute of Directors in New Zealand. What is governance? (n.d.). Retrieved 14/5/12 from https://www.iod.org.nz/FirstBoardsFirstDirectors/FirstBoards/Whatisgovernance.aspx

Institute of Directors in New Zealand. (n.d.). Publications. Retrieved 26/3/14 from https://www.iod.org.nz/Publications.aspx

Jackson, S., Josi, A., \& Erhardt, N. (2003). Recent research on team and organizational diversity: SWOT analysis and implications. Journal of Management, 29(6): 801-830. doi:10.1016/S0149-2063(03)00080-1

Jarrell, G. A., Brickley, J. A., \& Netter, J. M. (1988). The market for corporate control: the empirical evidence since 1980. Journal of Economic Perspectives, 2(1): 49-68.

Jensen, M. C. (1983). The market for corporate control: the scientific evidence. Journal of Financial Economics, 11(1-4): 5-50.

Jensen, M. C. (2001). Value maximisation stakeholder theory and the corporate objective function. European Financial Management, 7(3): 297-317.

Jensen, M. C., \& Meckling, W. H. (1976). Theory of the firm: managerial behaviour, agency costs and ownership structure. Journal of Financial Economics, 3(4): 305-360.

Johnson, J. L., Daily, C. M., \& Ellstrand, A. E. (1996). Boards of directors: A review and research agenda. Journal of Management, 22(3), 409-438.

Johnson, R. B., \& Turner, L. A. (2003). Data collection strategies in mixed methods research. In A.Tashakkori, and C. Teddlie (Eds.), Handbook of mixed methods in social and behavioural research (pp. 297-319). Thousand Oaks, CA: Sage. 
Johnson, S. G., Schnatterly, K., \& Hill, A. D. (2013). Board composition beyond independence: social capital, human capital, and demographics. Journal of Management, 39(1): 232-262. http://doi.org/10.1177/0149206312463938

Kakabadse, A., Kakabadse, N. K., \& Barratt, R. (2006). Chairman and chief executive officer (CEO): that sacred and secret relationship. Journal of Management Development, 25(2): 134-150. doi:10.1108/02621710610645126

Kane, E. J. (2012). Missing elements in US financial reform: a Kübler-Ross interpretation of the inadequacy of the Dodd-Frank Act. Journal of Banking \& Finance, 36(3): 654-661. http://doi.org/10.1016/j.jbankfin.2011.05.020

Karp, J. F., \& Axford, I. (2011). Can the US import 'sunlight' from New Zealand? An assessment of New Zealand's model for corporate financial disclosure. Fulbright New Zealand, Wellington.

Kiel, G. C., \& Nicholson, G. J. (2005). Evaluating boards and directors. Corporate Governance: An International Review, 13(5): 613-631.

Kim, H., \& Lim, C. (2010). Diversity, outside directors and firm valuation: Korean evidence. Journal of Business Research, 63(3): 284-291. http://doi.org/10.1016/j.jbusres.2009.01.013

Kim, Y., \& Cannella, A. A. (2008). Toward a social capital theory of director selection. Corporate Governance: An International Review, 16(4): 282-293. doi:10.1111/j.1467

Koerniadi, H., Krishnamurti, C., \& Tourani-Rad, A. (2014). Corporate governance and risk-taking in New Zealand. Australian Journal of Management, 39(2): 227-245. doi:10.1177/0312896213478332 
Koerniadi, H., \& Tourani-Rad, A. (2012). Does board independence matter? Evidence from New Zealand. Australasian Accounting, Business and Finance Journal, 6(2): 3-18.

Kor, Y. Y., \& Sundaramurthy, C. (2008). Experience-based human capital and social capital of outside directors. Journal of Management, 35(4): 981-1006. doi:10.1177/0149206308321551

Kosnik, R. D. (1987). Greenmail: a study of board performance in corporate governance. Administrative Science Quarterly, 32(2): 163. http://doi.org/10.2307/2393124

Kuprionis, M. D. (2011). Understanding board evaluations: analysis of purpose and key elements. The Corporate Governance Advisor, 19(3): 8-12.

La Porta, R., Lopez-de-Silanes, F., \& Shleifer, A. (1999). Corporate ownership around the world. Journal of Finance, 54(2): 471-517.

La Porta, R., Lopez-de-Silanes, F., \& Shleifer, A. (2006). What works in securities laws? Journal of Finance, 61(1): 1-32.

Larcker, D., \& Tayan, B. (2015). Corporate Governance Matters: a closer look at organizational choices and their consequences. Pearson FT Press, New Jersey.

Latham G., \& Yukl, G., (1975). A review of research on the application of goal setting in organizations. Academy of Management Journal, 18(4): 824-845.

Lazonick, W., \& O’Sullivan, M. (2000). Maximizing shareholder value: a new ideology for corporate governance. Economy and Society, 29(1): 13-35. doi:10.1080/030851400360541

Leblanc, R. W. (2004). What's Wrong with Corporate Governance: a note. Corporate Governance: An International Review, 12(4), 436-441. 
Leblanc, R., \& Schwartz, M. S. (2007). The black box of board process: gaining access to a difficult subject. Corporate Governance: An International Review, 15(5): 843-851.

Linck, J. S., Netter, J. M., \& Yang, T. (2009). The effects and unintended consequences of the Sarbanes-Oxley Act on the supply and demand for directors. Review of Financial Studies, 22(8): 3287-3328. doi:10.1093/rfs/hhn084

Linsley, C., \& Linsley, C. (2008). Impact of the Sarbanes-Oxley Act upon management: a behavioural discussion. Managerial Auditing Journal, 23(4): 313-327. doi:10.1108/02686900810864282

Lipton, M., \& Lorsch, J. W. (1992). A modest proposal for improved corporate governance. Business Lawyer, 48(1): 59-77.

Long, T. (2006). This year's model: influences on board and director evaluation. Corporate Governance: An International Review, 14(6): 547-557.

Macey, J. R. (2008). Corporate Governance: promises kept, promises broken. Princeton University Press, Princeton.

Marshall, B. R., \& Anderson, H. D. (2009). Regulation and target takeover returns: is there a link? Pacific-Basin Finance Journal, 17(4): 395-412. doi:10.1016/j.pacfin.2008.10.002

Masulis, R. W., Wang, C., \& Xie, F. (2012). Globalizing the boardroom: the effects of foreign directors on corporate governance and firm performance. Journal of Accounting and Economics, 53(3): 527-554. http://doi.org/10.1016/j.jacceco.2011.12.003

Maume, P., \& Walker, G. (2012). Enforcing financial markets law in New Zealand. New Zealand Law Review, 263-300. 
Meier, C. (2014). Another call for gender quotas (n.d.). Retrieved 13/11/2014 from http://www.stuff.co.nz/business/9963956/NZX-has-duty-to-impose-gender-quotas-in-NZ$\underline{\text { boardrooms }}$

Ministry of Business Innovation and Enterprise (2014). The New Zealand Companies Office Home Page. Retrieved from http://www.business.govt.nz/companies/welcome-to-the-companiesoffice-online

Ministry of Women (2014). More women on boards. Retrieved 26/3/14 from http://mwa.govt.nz/more-women-boards

Mitchell, D., Fortmann, W., \& Weiss. J. (2013). ESG Board Matters Macquarie Equities Research 11 November 2013

Mohd-Sulaiman, A. N. (2013). 'But we had obtained professional/legal advice!' The disclosure conundrum and directors' dilemma. Journal of Financial Crime, 20(3): 312-323. doi:10.1108/JFC-03-2013-0015

Molz, R. (1985). The role of the board of directors: typologies of interaction. Journal of Business Strategy, 5(4): 86-93.

Monks, A. R., (2001). Redesigning corporate governance structures and systems for the twenty-first century. Governance, 9(3): 142-147.

Monks, R. A. G., \& Minow, N. (1995). Corporate Governance. Blackwell, Cambridge, MA.

Narimu, K. (2012). Why women should be bosses (n.d.). Retrieved 13/11/14 from http://www.stuff.co.nz/dominion-post/comment/7288023/Why-women-should-be-bosses

New York Stock Exchange NYSE Listing Manual. Retrieved 28/7/14 from http://nysemanual.nyse.com/LCM/Sections/ 
New Zealand Market Disciplinary Tribunal (2012). Annual Report 2012, from https://www.nzx.com/files/documents/regulators/DISP/80_NZMDT_2012_ANNUAL_REP ORT.pdf

New Zealand Market Disciplinary Tribunal (2013). Annual Report 2013, from https://www.nzx.com/files/documents/regulators/DISP/79_NZMDT_2013_ANNUAL_REP ORT.pdf

New Zealand Super Fund (April 2015). NZ Super Fund suspends Milford Asset Management. Retrieved 17/4/15 from https://www.nzsuperfund.co.nz/news-media/nz-super-fundsuspends-milford-asset-management

Nguyen, B. D., \& Nielsen, K. M. (2010). The value of independent directors: evidence from sudden deaths. Journal of Financial Economics, 98(3): 550-567. doi:10.1016/j.jfineco.2010.07.004

Nicholson, G. J., \& Kiel, G. C. (2007). Can directors impact performance? A case-based test of three theories of corporate governance. Corporate Governance: An International Review, 15(4): 585-608.

Nicholson, G. J., \& Newton, C. J. (2010). The role of the board of directors: perceptions of managerial elites. Journal of Management \& Organization, 16(2): 204-218.

Nielsen, S., \& Huse, M. (2010). The contribution of women on boards of directors: going beyond the surface. Corporate Governance: An International Review, 18(2), 136-148. doi:10.1111/j.1467-8683.2010.00784.x

Northcott, D., \& Smith, J. (2011). Managing performance at the top: a balanced scorecard for boards of directors. Journal of Accounting and Organizational Change, 7(1): 33-56.

Nuzzo, R. (2014). Statistical errors. Nature, 506(13): 150-152. 
NYSE, New York Stock Exchange (2010). Report of the New York Stock Exchange Commission on Corporate Governance. Retrieved May 26, 2012, from

http://www.nyse.com/pdfs/CCGReport.pdf

NZX Limited (2012). NZSX/NZDX Listing Rules, October 2012.

NZX Limited (2013). NZX Main board and Debt Market Listing Rules, October 2013.

NZX Limited (2013). NZX All index. Retrieved 19/6/13 from https://www.nzX.com/markets/NZSX/indices/ALL NZX Ltd.

O’Leary, Z (2010). The essential guide to doing your research project. Sage ISBN-10: 1446258971

Ong, C. H., \& Wan, D. (2008). Three conceptual models of board role performance. Corporate Governance, 8(3): 317-329. doi:10.1108/14720700810879196.

Organization for Economic Co-operation and Development (2004). OECD Principles of Corporate Governance. Retrieved from http://www.oecd.org/dataoecd/32/18/31557724.pdf

Orr, D., Emanuel, D., \& Wong, N. (2005). Board composition and the value of New Zealand companies. Pacific Accounting Review, 17(2): 103-121.

Petra, S. T., \& Loukatos, G. (2009). The Sarbanes-Oxley Act of 2002: a five-year retrospective. Corporate Governance, 9(2): 120-132. doi:10.1108/14720700910946578

Petrovic, J. (2008). Unlocking the role of a board director: a review of the literature. Management Decision, 46(9): 1373-1392.

Qiu, H., and Yao, S. (2009). Share merger reform, corporate governance and firm value in China. 22nd Australasian Finance and Banking Conference 2009. Available from http://ssrn.com/abstract=1275699 or http://dx.doi.org/10.2139/ssrn.1275699 
QV Monthly Residential Value Index (n.d.). Retrieved 27/3/14 from http://www.qv.co.nz/resources/monthly-residential-value-index

R v Graham (2012). CRI-2010-085-2538 [2012] NZHC 575. Retrieved from LexisNexis Academic Database. Also available from http://www.chrislee.co.nz/uploads/Lombard\%20R\%20v\%20Graham\%20Sentence\%201303 12.pdf $15 / 11 / 15$

Raziq, M. M., \& Perry, M. (2012). Foreign direct investment in New Zealand: does it justify negative assessment? Foreign direct investment in New Zealand. Regional Science Policy \& Practice, 4(2): 155-164. http://doi.org/10.1111/j.1757-7802.2012.01063.x

Reddy, K., Locke, S., \& Scrimgeour, F. (2010). The efficacy of principle-based corporate governance practices and firm financial performance: an empirical investigation. International Journal of Managerial Finance, 6(3): 190-219. doi:10.1108/17439131011056224

Regierungskommission Deutscher Corporate Governance Codex (n.d.). Retrieved 1/8/15 from http://www.dcgk.de/en/code//foreword.html

Reserve Bank C19 household financial assets (quarterly, \$m) (n.d.). Retrieved 22/3/14 from http://www.rbnz.govt.nz/statistics/tables/c19/

Rock, E. B. (1990). Logic and (Uncertain) Significance of Institutional Shareholder Activism, The. Geo. LJ, 79, 445 .

Romano, R. (2004). The Sarbanes-Oxley Act and the making of quack corporate governance. Retrieved 27/3/15 from http://papers.ssrn.com/sol3/Papers.cfm?abstract id=596101 
Rural News Group (2011). Overseas directors lacking? Rural News, 22 June 2011. Retrieved 29/8/15 from http://www.ruralnewsgroup.co.nz/rural-news/rural-agribusiness/overseasdirectors-lacking

Rutherford, H. (2012). Graham won't take conviction on chin. Business Day, 13/4/12. Retrieved 19/11/12 from http://www.stuff.co.nz/business/money/6734297/Graham-won-t-takeconviction-on-chin

Schapiro, M. (2010). Opening Statement at the SEC Open Meeting (Chairman Mary L. Schapiro; 25 August 2010). (n.d.) Retrieved 23/5/15 from http://www.sec.gov/news/speech/2010/spch082510mls.htm

Schwarz, N. (1999). Self-reports: how the questions shape the answers. American Psychologist, 54(2): 93-105.

Sealy, R., \& Vinnicombe, S. (2013). The Female FTSE board report 2013: false dawn of progress for women on boards? Retrieved from https://dspace.lib.cranfield.ac.uk/handle/1826/8005

Securities Commission of New Zealand (2004). Corporate Governance in New Zealand: principles and guidelines. Securities Commission of New Zealand, Wellington.

Securities and Exchange Commission: facts \& summary (n.d.). Retrieved 11/9/14 from http://www.history.com/topics/securities-and-exchange-commission

Shen, W. (2003). The dynamics of the CEO-board relationship: an evolutionary perspective. Academy of Management Review, 28(3): 466. doi:10.2307/30040733

Shivdasani, A., \& Yermack, D. (1999). CEO involvement in the selection of new board members: An empirical analysis. The Journal of Finance, 54(5), 1829-1853. 
Shleifer, A., \& Vishny, R. W. (1996). A survey of corporate governance. Journal of Finance, 52(2): $737-783$.

Singh, K. (2007). Quantitative social research methods. Sage

Singh, V., Terjesen, S., \& Vinnicombe, S. (2008). Newly appointed directors in the boardroom. European Management Journal, 26(1): 48-58. http://doi.org/10.1016/j.emj.2007.10.002

Smith, A. (1776). An Inquiry into the Nature and Causes of the Wealth of Nations. Project Gutenberg e-book \#3300, 2009.

Smith, J. H. (2003). The shareholders vs. stakeholders debate. Sloan Management Review, 44(4): $85-94$.

Solomon, J., \& Solomon, A. (2004). Corporate Governance and Accountability. John Wiley \& Sons, Chichester.

Sonnenfeld, J. (2004). Good governance and the misleading myths of bad metrics. Academy of Management Executive, 18(1): 108-113.

Statistics NZ (2013). 2013 Census. Retrieved from http://www.stats.govt.nz/Census/2013$\underline{\text { census.aspx }}$

Stemler, S. (2001). An overview of content analysis. Practical Assessment, Research \& Evaluation, 7(17), 137-146.

Sternberg, E. (1997). The defects of stakeholder theory. Corporate Governance: An International Review, 5(1): 3-10. 
Stevenson, W. B., \& Radin, R. F. (2009). Social capital and social influence on the board of directors. Journal of Management Studies, 46(1): 16-44. doi:10.1111/j.14676486.2008.00800.x

Stewart, T. (2012). Feltex class action swells by 800 (n.d.). Retrieved 27/2/13 from http://www.stuff.co.nz/business/industries/6394683/Feltex-class-action-swells-by-800

Strätling, R. (2003). General Meetings: a dispensable tool for corporate governance of listed companies?. Corporate Governance: An International Review, 11(1), 74-82.

Sundaramurthy, C., \& Lewis, M. (2003). Control and collaboration: paradoxes of governance. Academy of Management Review, 28(3): 397-415.

Tan, A. W., \& Keeper, T. (2008). Institutional investors and corporate governance: a New Zealand perspective. Retrieved 20/10/14 from http://researcharchive.vuw.ac.nz/handle/10063/2206

Terjesen, S., \& Singh, V. (2008). Female presence on corporate boards: a multi-country study of environmental context. Journal of Business Ethics, 83(1): 55-63. doi:10.1007/s10551-0079656-1

Thomas, R. S., \& Watson, S. (2013). Should New Zealand adopt say on pay? New Zealand Business Law Quarterly, 19(2): 111-137.

Thompson, R. B., \& Edelman, P. H. (2009). Corporate voting. Vanderbilt Law Review, 62(1): 127.

TIAA-CREF (2012). Policy Statement on Corporate Governance (6th edition). Retrieved from https://www.tiaa-cref.org/public/pdf/pubs/pdf/governance_policy.pdf

Todd, G. (1932). Some aspects of joint stock companies, 1844-1900. Economic History Review, 4(1): 46-71. 
Tolich M., \& Davidson C., (2011) An introduction to research methods: getting started. Pearson, New Zealand. ISBN: 978-1-4425-4736-0

Tosi, H. L., Werner, S., Katz, J.P., \& Gomez-Mejia, L. R. (2000). How much does performance matter? A meta-analysis of CEO pay studies. Journal of Management, 20(2): 301-339.

Tricker, R. I. (1984). Corporate Governance. Gower Publishing, Aldershot.

Turnbull, N. (1999). Internal Control: guidance for directors on the combined code. Institute of Chartered Accountants in England \& Wales, London.

Turnbull, S. (1997). Corporate governance: its scope, concerns and theories. Corporate Governance: An International Review, 5(4): 180-205.

Underhill, N. (2012). Feltex directors fail in bid to stop class action. NZ Herald, 23/11/12. Retrieved 29/7/14 from http://www.nzherald.co.nz/business/news/article.cfm?c_id=3\&objectid=10849565

United Nations (2006). Guidance on good practices in corporate governance disclosure. UN Publications, New York.

United States General Accounting Office, Program Evaluation and Methodology Division (1993). Developing and using questionnaires. USGAO, Washington DC.

Vafeas, N. (2003). Length of board tenure and outside director independence. Journal of Business Finance \& Accounting, 30(7-8): 1043-1064.

Van den Eynden, V., Corti, L., Woollard, M., Bishop, L., \& Horton, L. (2011). Managing and sharing data: best practice for researchers. Retrieved 15/10/14 from http://www.vliz.be/imisdocs/publications/230729.pdf. 
Van der Walt, N., \& Ingley, C. (2003). Board dynamics and the influence of professional background, gender and ethnic diversity of directors. Corporate Governance: An International Review, 11(3): 218-234

Van der Walt, N., Ingley, C., Shergill, G. S., \& Townsend, A. (2006). Board configuration: are diverse boards better boards?. Corporate Governance: The international journal of business in society, 6(2), 129-147.

Veasey, E. N., \& Di Guglielmo, C. T. (2005). What happened in Delaware corporate law and governance from 1992-2004? A retrospective on some key developments. University of Pennsylvania Law Review, 153(5): 1399-1512.

Vinten, G. (2001). Shareholder versus stakeholder - is there a governance dilemma? Corporate Governance: An International Review, 9(1): 36-47.

Von Rosen, R. (2007). Corporate governance in Germany. Journal of Financial Regulation and Compliance, 15(1): 30-41. doi:10.1108/13581980710726778

Wang, C. (2004). Variation (coefficient of). In M. Lewis-Beck, A. Bryman, \& T. Liao (eds), Encyclopaedia of Social Science Research Methods. SAGE Publications, Thousand Oaks, pp 1178-1179. doi: http://dx.doi.org/10.4135/9781412950589.n1069

Wang, M., \& Kelan, E. (2013). The gender quota and female leadership: Effects of the Norwegian gender quota on board chairs and CEOs. Journal of business ethics, 117(3), 449-466

Weir, C., \& Laing, D. (2000). The performance-governance relationship: the effects of Cadbury compliance on UK quoted companies. Journal of Management and Governance, 4(4): 265281. 
Weisberg, H. F. (1992). Measures of Spread. SAGE Publications, Thousand Oaks. doi: http://dx.doi.org.helicon.vuw.ac.nz/10.4135/9781412983617.n4

Westphal, J. D. (1999). Collaboration in the boardroom: behavioural and performance consequences of CEO-board social ties. Academy of Management Journal, 42(1): 7-24. http://doi.org/10.2307/256871

Westphal, J. D., \& Fredrickson, J. W. (2001). Who directs strategic change? Director experience, the selection of new CEOs, and change in corporate strategy. Strategic Management Journal, 22(12): 1113-1137. http://doi.org/10.1002/smj.205

Westphal, J. D., \& Zajac, E. J. (1995). Who shall govern? CEO/board power, demographic similarity, and new director selection. Administrative Science Quarterly, 40(1): 60. http://doi.org/10.2307/2393700

Whittaker, D. (2012). Are there enough qualified and experienced directors? Retrieved 2/5/14 from https://www.iod.org.nz/News/IoDnewsandarticles/Article/tabid/308/itemId/24/Are-thereenough-qualified-and-experienced-directo.aspx

Wilson, W. R., Rose, L. C., \& Pinfold, J. F. (2010). Examination of NZ finance company failures: the role of corporate governance. Finance and Corporate Governance Conference. Retrieved 20/12/13 from http://papers.ssrn.com/sol3/Delivery.cfm?abstractid=1536874

Wolf, F. M. (1986). Meta-analysis: quantitative methods for research synthesis. Sage Publications, Newbury Park.

Yang, J., Chi, J., \& Young, M. (2011). A review of corporate governance in China: CHINA CORPORATE GOVERNANCE. Asian-Pacific Economic Literature, 25(1), 15-28. http://doi.org/10.1111/j.1467-8411.2011.01283.x 
Yeh, Y.-H. (2005). Do controlling shareholders enhance corporate value? Corporate Governance: An International Review, 13(2): 313-325.

Yermack, D. (1996). Higher valuation of companies with a small board of directors. Journal of Financial Economics, 40(2): 185-212.

Zalewska, A. (2013). Challenges of corporate governance: twenty years after Cadbury, ten years after Sarbanes-Oxley. Journal of Empirical Finance, 27: 1-144. doi:10.1016/j.jempfin.2013.12.004

Zattoni, A., \& Cuomo, F. (2010). How independent, competent and incentivized should nonexecutive directors be? An empirical investigation of good governance codes. British Journal of Management, 21(1): 63-79. doi:10.1111/j.1467-8551.2009.00669.x

Zattoni, A., Douglas, T., \& Judge, W. (2013). Developing corporate governance theory through qualitative research. Corporate Governance: An International Review, 21(2): 119-122. http://doi.org/10.1111/corg.12016 


\section{APPENDIX A. AVERAGE TIME NZSX SHARES ARE HELD}

A summary of monthly share trading volumes on NZSX for July 2013 was obtained from NZX.

The average number of days shares were held was obtained by dividing the total shares on issue by average daily trading volumes. Figure 20 shows the average number of days the 20 most traded stocks were held and the average number of trades on each day. Given that $83 \%$ of shareholders surveyed planned to hold shares they purchase for more than a year (Table 33, p.185), this suggests that institutional investors are actively trading shares. The large volume of trades each day may also suggest algorithmic or computer-generated trading.

\section{Figure 20}

The 20 most actively traded shares, July 2013

\begin{tabular}{|c|c|c|c|c|}
\hline $\begin{array}{l}\text { Security } \\
\text { Code }\end{array}$ & Shares on issue & $\begin{array}{l}\text { Shares traded } \\
\text { in July } 2013\end{array}$ & $\begin{array}{l}\text { Average } \\
\text { days held }\end{array}$ & $\begin{array}{l}\text { Average } \\
\text { daily trades }\end{array}$ \\
\hline $1 \mathrm{TME}$ & $396,554,115$ & $1,028,743,650$ & 12 & 2,887 \\
\hline $2 \mathrm{ZEL}$ & $400,000,000$ & $1,003,414,940$ & 12 & 1,332 \\
\hline 3 AIA & $1,322,754,089$ & $2,483,186,156$ & 17 & 5,562 \\
\hline $4 \mathrm{SKT}$ & $389,139,785$ & $723,209,124$ & 17 & 3,070 \\
\hline 5 TEL & $1,822,303,137$ & $3,124,057,288$ & 18 & 7,376 \\
\hline 6 STU & $88,444,240$ & $146,719,848$ & 19 & 553 \\
\hline 7 SKC & $580,016,676$ & $776,377,470$ & 23 & 3,746 \\
\hline $8 \mathrm{KMD}$ & $200,215,894$ & $267,554,122$ & 23 & 567 \\
\hline $9 \mathrm{CNU}$ & $396,369,767$ & $525,299,874$ & 23 & 4,149 \\
\hline $10 \mathrm{FBU}$ & $687,854,788$ & $884,001,558$ & 24 & 6,102 \\
\hline $11 \mathrm{NZX}$ & $255,547,723$ & $292,142,708$ & 27 & 770 \\
\hline 12 WYN & $102,567,777$ & $115,563,514$ & 28 & 903 \\
\hline $13 \mathrm{MOA}$ & $30,096,549$ & $33,708,004$ & 28 & 520 \\
\hline $14 \mathrm{FPH}$ & $546,838,267$ & $590,283,078$ & 29 & 3,276 \\
\hline $15 \mathrm{HNZ}$ & $392,554,579$ & $404,362,332$ & 30 & 349 \\
\hline 16 NPX & $198,125,827$ & $197,893,080$ & 31 & 978 \\
\hline $17 \mathrm{MRP}$ & $1,396,972,447$ & $1,247,455,748$ & 35 & 4,395 \\
\hline $18 \mathrm{SKL}$ & $192,805,807$ & $167,647,788$ & 36 & 637 \\
\hline $19 \mathrm{ABA}$ & $20,410,760$ & $17,226,286$ & 37 & 203 \\
\hline 20 PPG & $40,000,000$ & $30,672,466$ & 40 & 134 \\
\hline
\end{tabular}




\section{APPENDIX B DIRECTOR \& SHAREHOLDER SURVEYS}

Postal surveys were conducted with a sample of 400 directors and 1083 shareholders to determine their opinions and expectations of New Zealand public company boards. This appendix contains a copy of both the director survey and the shareholder survey. 


\section{It's all about}

\section{Governance}

In your opinion in practice who is the board ultimately responsible to: Please tick one

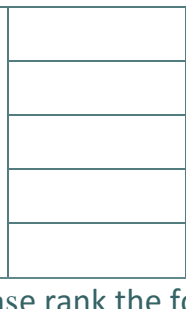

Shareholders

The company

All stakeholders including shareholders, staff and customers

Other (please specify)

Don't know

2 When considering the role of the board please rank the following six statements in order of importance

The most important should be ranked number 1 and the least important ranked number 6.

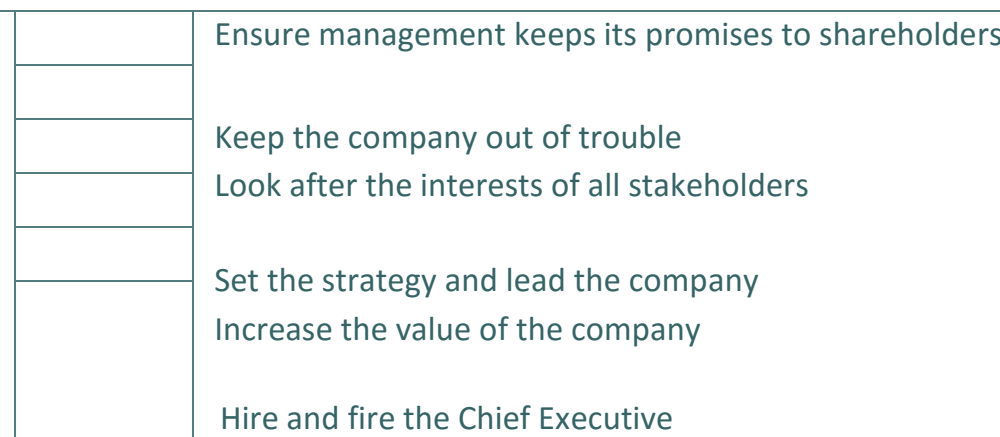

3 In the normal course of business when a company is trading profitably who should be responsible for the following tasks?

\begin{tabular}{|l|l|l|l|l}
\hline & Board & Management & No preference & Don't know
\end{tabular}

Setting company strategy

Setting company performance objectives

Setting annual budgets

Approving major investment expenditure

Ensuring clear lines of accountability throughout the organisation

When necessary replace CEO

When necessary replace senior executives

Setting Occupational Health and Safety Policy

Ensuring that the company complies with its legal obligations

Ensuring that the company meets its financial obligations

(e.g. meet banking covenants)

Overseeing the work of the Auditors

Reviewing and guiding risk policy

Reporting to shareholders

Communicating with the public

Communicating with other external stakeholders e.g. suppliers,

bankers

Approving related party transactions 
4 When a company is in a financial crisis who should be responsible for the following tasks?

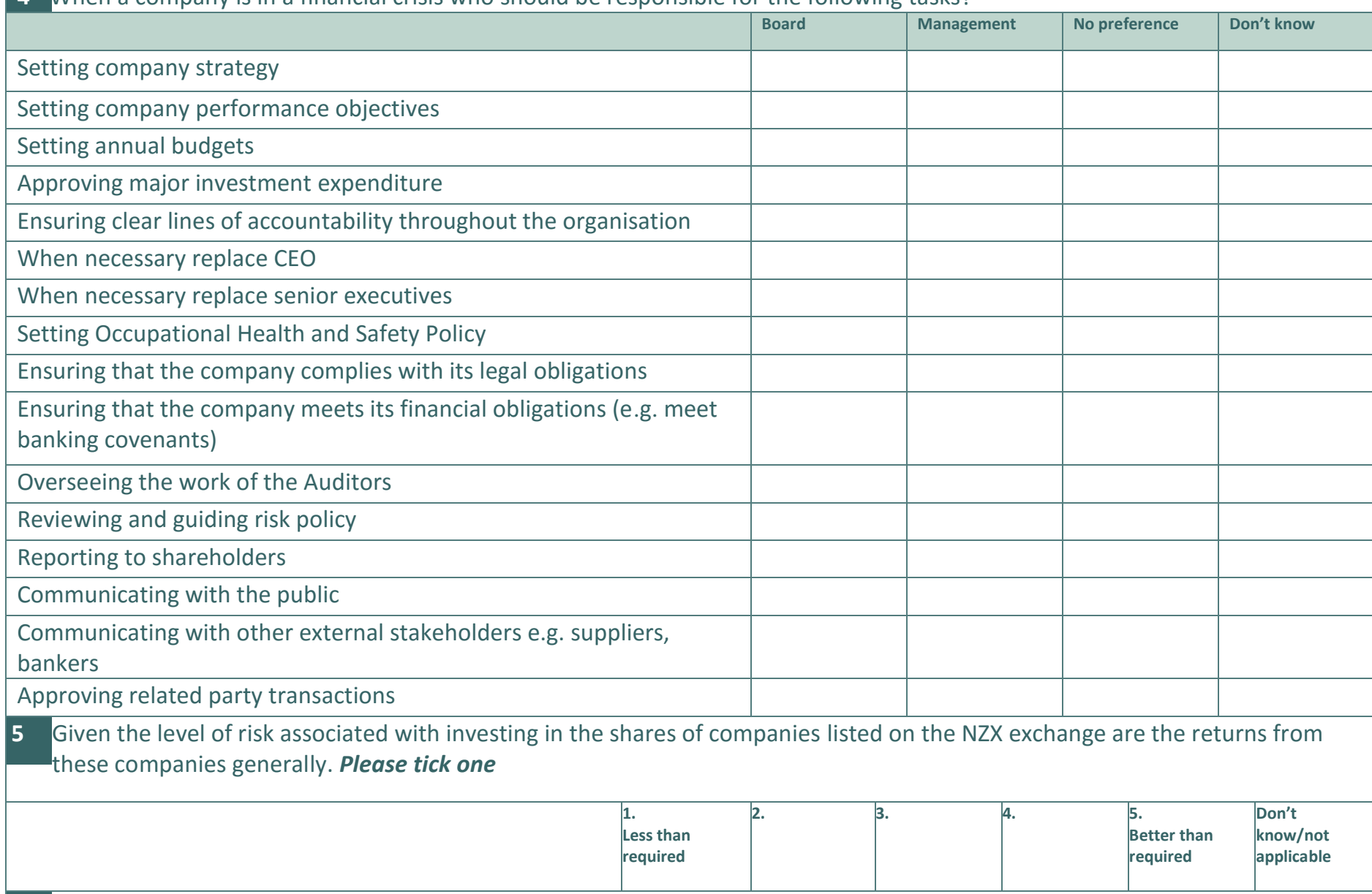

6 Do shareholders have realistic expectations of the returns they can expect from their investments in the shares of companies listed on the NZX exchange? Please tick one

\begin{tabular}{|l|l|l|l|l|}
\hline $\begin{array}{l}\text { Shareholders } \\
\text { expect less than is } \\
\text { realistic }\end{array}$ & 3. Realistic & 4. & $\begin{array}{l}5 . \\
\text { Shareholders } \\
\text { expect more } \\
\text { than is realistic }\end{array}$ \\
\hline
\end{tabular}

7 Do companies listed on the NZX exchange provide their shareholders with the right amount of financial information? Please tick one

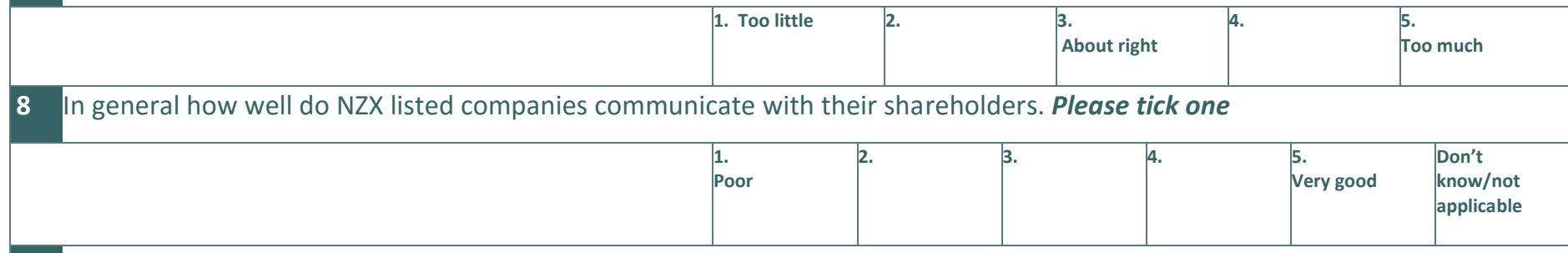

9 The role of the board in developing strategy is. Please tick one

\begin{tabular}{|l|l|} 
& $\begin{array}{l}\text { To develop the strategy on its own } \\
\text { To develop strategy in conjunction with management } \\
\text { To review and approve the strategy developed by management } \\
\text { Dependent on the company and the circumstances } \\
\text { Don't know }\end{array}$
\end{tabular}

10 Most companies listed on the NZX exchange would benefit from: Please tick one

\begin{tabular}{|l|l|}
\hline & $\begin{array}{l}\text { Only having independent directors on their board } \\
\text { Having only independent directors and the CEO on the board } \\
\text { Having a majority of independent directors on their board } \\
\text { The number of independent directors is not important } \\
\text { Don't know }\end{array}$
\end{tabular}




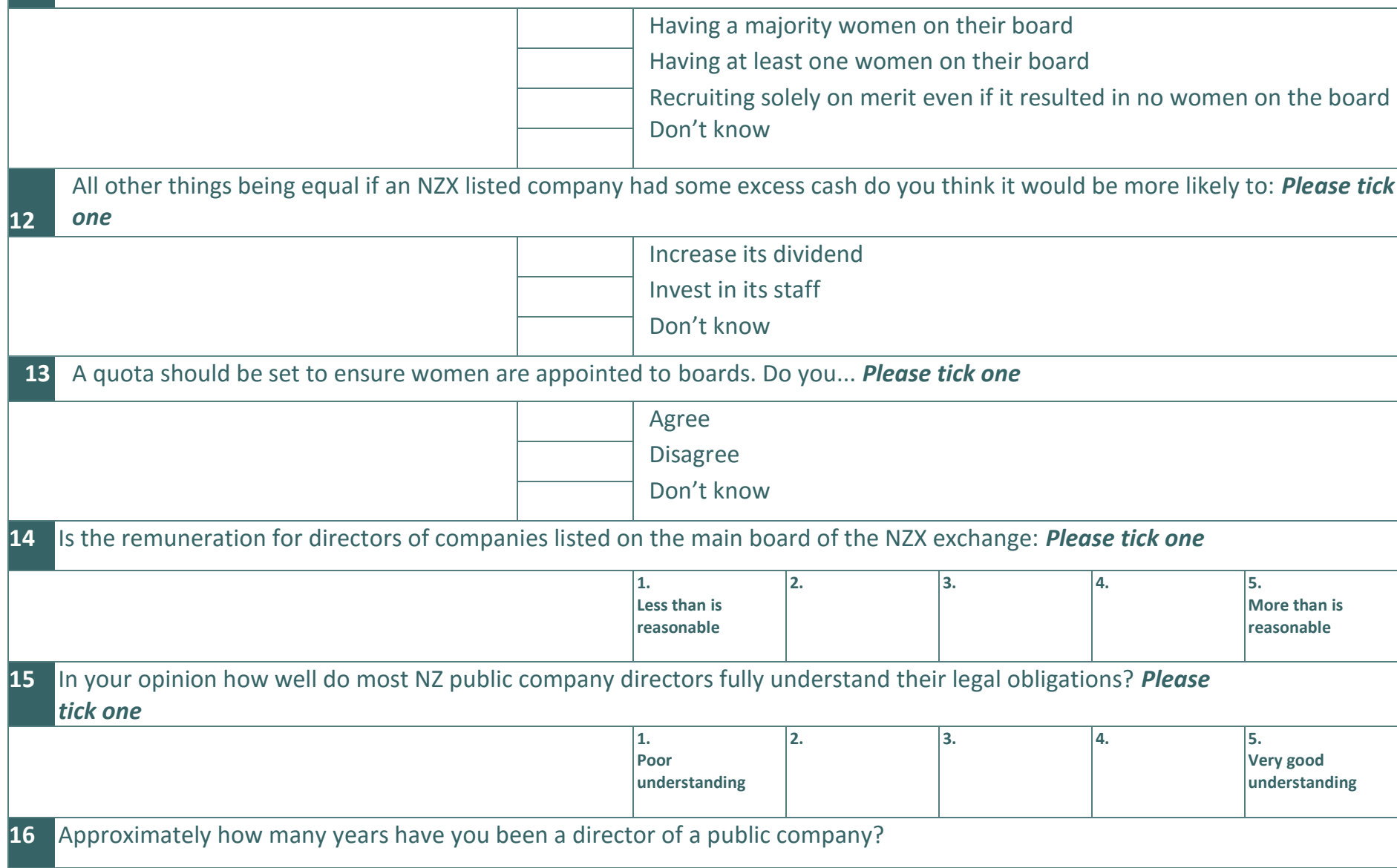

And that's it!

Thank you very much for taking the time to do this - its most appreciated. 


\section{It's all about}

\section{Governance}

1 Please rank the following four statements in order of importance.

The most important should be ranked number 1 and the least important ranked number 4.

\begin{tabular}{|l|l|}
\hline & $\begin{array}{l}\text { The board is responsible for running the company } \\
\text { The boards role is to oversee management and monitor the company } \\
\text { Board seats are a reward for executives who have had a distinguished } \\
\text { career } \\
\text { The board is an historical artefact with no real relevance to modern } \\
\text { business }\end{array}$ \\
\hline
\end{tabular}

2 In your opinion in practice who is the board ultimately responsible to: Please tick one

\begin{tabular}{|l|l|} 
& Shareholders \\
& The company \\
& All stakeholders \\
& Other (please specify) \\
& Don't know
\end{tabular}

3 In your opinion which of the following best describes the primary role of the board? Please tick one

\begin{tabular}{|l|l|}
\hline & $\begin{array}{l}\text { Ensure management keeps its promises to shareholders } \\
\text { Keep the company out of trouble } \\
\text { Look after the interests of all stakeholders } \\
\text { Set the strategy and lead the company } \\
\text { Increase the value of the company } \\
\text { Other (please specify) } \\
\text { Don't know }\end{array}$ \\
\cline { 1 - 2 }
\end{tabular}

4 In general do the boards of companies listed on the NZX exchange do a good job? Please tick one

\begin{tabular}{|l|l|l|l|l|l|}
\hline $\begin{array}{l}\text { Not very good } \\
\text { Non't }\end{array}$ & 3. & 4. & $\begin{array}{l}\text { S. } \\
\text { Very good } \\
\text { know/not } \\
\text { applicable }\end{array}$
\end{tabular}

5

In the normal course of business when a company is trading profitably who should be responsible for the following tasks?

\begin{tabular}{|l|l|l|l|l|}
\hline Setting company strategy & Board & Management & No preference & Don't know \\
\hline Setting company performance objectives & & & & \\
\hline Setting annual budgets & & & & \\
\hline Approving major investment expenditure & & & & \\
\hline Ensuring clear lines of accountability throughout the organisation & & & & \\
\hline When necessary replace CEO & & & & \\
\hline When necessary replace senior executives & & & & \\
\hline Setting Occupational Health and Safety Policy & & & & \\
\hline Ensuring that the company complies with its legal obligations & & & & \\
\hline Ensuring that the company meets its financial obligations & & & \\
\hline
\end{tabular}


Overseeing the work of the Auditors

Reviewing and guiding risk policy

Reporting to shareholders

Communicating with other external parties e.g. suppliers, bankers

Approving related party transactions

When a company is in a financial crisis who in your opinion should be responsible for the following tasks?

6

\begin{tabular}{|c|c|c|c|c|}
\hline & Board & Management & No preference & Don't know \\
\hline \multicolumn{5}{|l|}{ Setting company strategy } \\
\hline \multicolumn{5}{|l|}{ Setting company performance objectives } \\
\hline \multicolumn{5}{|l|}{ Setting annual budgets } \\
\hline \multicolumn{5}{|l|}{ Approving major investment expenditure } \\
\hline \multicolumn{5}{|l|}{ Ensuring clear lines of accountability throughout the organisation } \\
\hline \multicolumn{5}{|l|}{ When necessary replace CEO } \\
\hline \multicolumn{5}{|l|}{ When necessary replace senior executives } \\
\hline \multicolumn{5}{|l|}{ Setting Occupational Health and Safety Policy } \\
\hline \multicolumn{5}{|l|}{ Ensuring that the company complies with its legal obligations } \\
\hline \multicolumn{5}{|l|}{ Ensuring that the company meets its financial obligations } \\
\hline \multicolumn{5}{|l|}{ Overseeing the work of the Auditors } \\
\hline \multicolumn{5}{|l|}{ Reviewing and guiding risk policy } \\
\hline \multicolumn{5}{|l|}{ Reporting to shareholders } \\
\hline Communicating with other external parties e.g. suppliers, bankers & & & & \\
\hline Approving related party transactions & & & & \\
\hline
\end{tabular}

7 When a company is in financial crisis in your ipinion whose interests' do directors generally put first and second?

Please mark their first interest with the number 1 and their second interest with the number 2

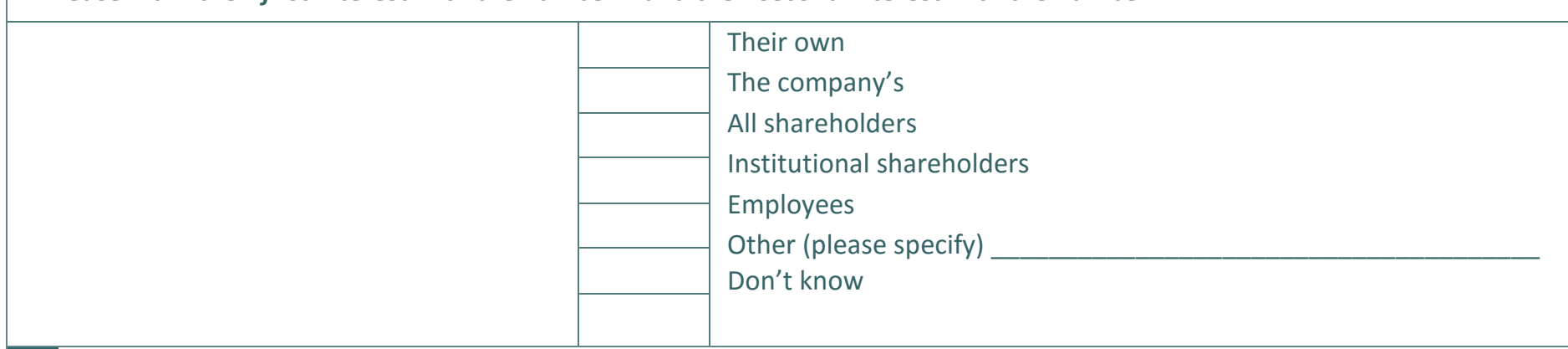

All other things being equal if an NZX listed company had some excess cash do you think it would be more likely to: Please tick one

\begin{tabular}{|l|l|}
\hline & $\begin{array}{l}\text { Increase its dividend } \\
\text { Invest in its staff } \\
\text { Don't know }\end{array}$
\end{tabular}

9 Given the level of risk associated with investing in the shares of companies listed on the NZX exchange are the returns generally Please tick one

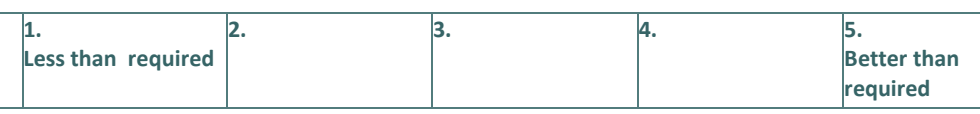

10 In general how would you rate the financial information provided to shareholders by NZX listed companies? Please tick one

\begin{tabular}{|l|l|l|l|l|l|}
\hline $\begin{array}{l}1 . \\
\text { Poor }\end{array}$ & 2. & 3. & $\begin{array}{l}5 . \\
\text { Very good }\end{array}$ & $\begin{array}{l}\text { Don't } \\
\text { know/not } \\
\text { applicable }\end{array}$ \\
\hline
\end{tabular}

11 In general how well do NZX listed companies communicate with their shareholders. Please tick one 


\begin{tabular}{|l|l|l|l|l|l|l|l|l|}
\hline Poor & 2. & 3. & $\begin{array}{l}5 . \\
\text { Very good }\end{array}$ & $\begin{array}{l}\text { Don't } \\
\text { know/not } \\
\text { applicable }\end{array}$ \\
\hline
\end{tabular}

12 An independent director is not associated with either management or a major shareholder. In your opinion would NZ's public companies most benefit from: Please tick one

13 Would most NZ's public companies would most benefit from: Please tick one

Only having independent directors on their board Having only independent directors and the CEO on the board Having a majority of independent directors on their board The number of independent directors is not important Don't know

\begin{tabular}{|l|l|l}
\hline & & Having a majority women on their board
\end{tabular}

Having at least one women on their board

Recruiting solely on merit even if it resulted in no women on the board Don't know

14 Is the remuneration for directors of companies listed on the NZX exchange: Please tick one

\begin{tabular}{|l|l|l|l|l|l|}
\hline & $\begin{array}{l}1 . \\
\text { Less than is } \\
\text { reasonable }\end{array}$ & 2. & $\begin{array}{l}3 . \\
\text { About right }\end{array}$ & $\begin{array}{l}4 . \\
\begin{array}{l}5 . \\
\text { More than is } \\
\text { reasonable }\end{array}\end{array}$ & $\begin{array}{l}\text { Don't } \\
\text { know/not } \\
\text { applicable }\end{array}$ \\
\hline
\end{tabular}

15 For approximately how many years have you invested in NZ company shares?

16 Approximately how many companies listed on the NZX do you hold shares in?

When you buy shares is usually your intention to. Please tick one

17

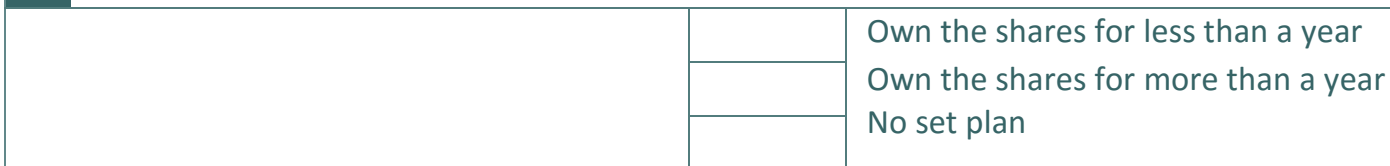

18 Which of the following best describes your approach to the share market. Please tick one

\begin{tabular}{|c|c|}
\hline & \multirow{5}{*}{$\begin{array}{l}\text { I don't take it too seriously - I invest occasionally and for fun } \\
\text { I'm not that experienced, I rely on brokers or other experts to select } \\
\text { almost all the shares I purchase } \\
\text { I am reasonably knowledgeable and experienced and I often rely on } \\
\text { advice from brokers or other experts before buying or selling shares } \\
\text { I know what I'm doing and I buy and sell shares regularly }\end{array}$} \\
\hline & \\
\hline & \\
\hline & \\
\hline & \\
\hline \multicolumn{2}{|c|}{ Are you a male or female? Please tick one } \\
\hline \multirow{2}{*}{ female } & male \\
\hline & \\
\hline
\end{tabular}

And that's it!

Thank you very much for taking the time to do this - its most appreciated. 


\section{APPENDIX C DIRECTORS' AND SHAREHOLDERS' EXPECTATIONS OF THE TASKS A BOARD SHOULD PERFORM COMPARED}

\section{Table 42}

Directors' and shareholder' expectations of the tasks a board should perform when a company is trading normally.

Director Expectations

Shareholder Expectations

\begin{tabular}{|c|c|c|c|c|c|c|c|c|c|c|c|c|c|}
\hline & \multicolumn{6}{|c|}{ Director Expectations } & \multicolumn{6}{|c|}{ Shareholder Expectations } & \multirow[b]{2}{*}{ P value } \\
\hline & Board & $\begin{array}{l}\text { Manag } \\
\text { ement }\end{array}$ & Both & $\begin{array}{r}\text { No } \\
\text { Pref }\end{array}$ & $\begin{array}{l}\text { Don't } \\
\text { Know }\end{array}$ & Total & Board & $\begin{array}{l}\text { Manag } \\
\text { ement }\end{array}$ & Both & $\begin{array}{l}\text { No } \\
\text { Pref }\end{array}$ & $\begin{array}{l}\text { Don't } \\
\text { Know }\end{array}$ & Total & \\
\hline Setting company strategy & 100 & 11 & 17 & 0 & 0 & 128 & 281 & 63 & 7 & 1 & 19 & 371 & $<0.000$ \\
\hline Setting company performance objectives & 85 & 26 & 17 & 0 & 0 & 128 & 153 & 196 & 5 & 1 & 16 & 371 & $<0.000$ \\
\hline Setting annual budgets & 53 & 58 & 16 & 0 & 0 & 128 & 86 & 266 & 5 & 1 & 12 & 370 & $<0.000$ \\
\hline $\begin{array}{l}\text { Approving major investment expenditure } \\
\text { Ensuring clear lines of accountability }\end{array}$ & 115 & 7 & 3 & 2 & 0 & 128 & 333 & 28 & 0 & 2 & 5 & 368 & 0.016 \\
\hline throughout the organisation & 41 & 74 & 11 & 0 & 0 & 128 & 134 & 227 & 4 & 1 & 5 & 371 & $<0.000$ \\
\hline $\begin{array}{l}\text { Where necessary replacing CEO } \\
\text { Where necessary replacing senior }\end{array}$ & 123 & 3 & 0 & 0 & 0 & 128 & 353 & 14 & 1 & 3 & 3 & 374 & 0.556 \\
\hline $\begin{array}{l}\text { executives } \\
\text { Setting occupational health and safety }\end{array}$ & 7 & 113 & 8 & 0 & 0 & 126 & 120 & 231 & 5 & 3 & 15 & 374 & $<0.000$ \\
\hline $\begin{array}{l}\text { policy } \\
\text { Ensuring the company complies with its }\end{array}$ & 85 & 29 & 14 & 0 & 0 & 128 & 64 & 294 & 7 & 2 & 8 & 375 & $<0.000$ \\
\hline $\begin{array}{l}\text { legal obligations } \\
\text { Ensuring the company meets its financial }\end{array}$ & 62 & 44 & 21 & 1 & 0 & 127 & 163 & 174 & 10 & 2 & 25 & 374 & $<0.000$ \\
\hline obligations & 65 & 45 & 16 & 2 & 0 & 128 & 190 & 140 & 9 & 3 & 29 & 371 & $<0.000$ \\
\hline Overseeing the work of the auditors & 97 & 24 & 3 & 2 & 0 & 128 & 206 & 129 & 12 & 9 & 10 & 366 & 0.001 \\
\hline Reviewing and guiding risk policy & 106 & 12 & 8 & 2 & 0 & 126 & 214 & 124 & 11 & 16 & 15 & 380 & $<0.000$ \\
\hline Reporting to shareholders & 103 & 9 & 14 & 2 & 0 & 127 & 281 & 38 & 9 & 3 & 39 & 370 & $<0.000$ \\
\hline $\begin{array}{l}\text { Communicating with external } \\
\text { stakeholders }\end{array}$ & 5 & 111 & 11 & 1 & 0 & 127 & 21 & 329 & 7 & 2 & 14 & 373 & $<0.002$ \\
\hline Approving related party transactions & 117 & 7 & 3 & 0 & 0 & 128 & 249 & 71 & 15 & 23 & 10 & 368 & $<0.000$ \\
\hline
\end{tabular}




\section{Table 43}

Directors' and shareholders' expectations of the tasks a board should perform when a company is under financial stress

Director Expectations

Shareholder Expectations

Setting company strategy

Setting company performance objectives

Setting annual budgets

Approving major investment expenditure

Ensuring clear lines of accountability

throughout the organisation

Where necessary replacing CEO

Where necessary replacing senior

executives

Setting occupational health and safety

policy

Ensuring the company complies with its

legal obligations

Ensuring the company meets its financial

obligations

Overseeing the work of the auditors

Reviewing and guiding risk policy

Reporting to shareholders

Communicating with external

stakeholders

Approving related party transactions

\begin{tabular}{|c|c|c|c|c|c|c|c|c|c|c|c|c|}
\hline Board & $\begin{array}{c}\text { Manag } \\
\text { ement }\end{array}$ & Both & $\begin{array}{l}\text { No } \\
\text { Pref }\end{array}$ & $\begin{array}{l}\text { Don't } \\
\text { Know }\end{array}$ & Total & Board & $\begin{array}{c}\text { Manag } \\
\text { ement }\end{array}$ & Both & $\begin{array}{l}\text { No } \\
\text { Pref }\end{array}$ & $\begin{array}{l}\text { Don't } \\
\text { Know }\end{array}$ & Total & $P$ value \\
\hline 99 & 7 & 16 & 1 & 0 & 123 & 311 & 23 & 4 & 1 & 17 & 356 & $<0.000$ \\
\hline 98 & 9 & 15 & 0 & 0 & 123 & 227 & 96 & 2 & 1 & 22 & 348 & $<0.000$ \\
\hline 69 & 40 & 13 & 0 & 0 & 123 & 160 & 164 & 3 & 2 & 17 & 346 & $<0.000$ \\
\hline 115 & 4 & 2 & 1 & 0 & 123 & 326 & 10 & 5 & 3 & 7 & 351 & 0.638 \\
\hline 64 & 50 & 8 & 1 & 0 & 123 & 147 & 176 & 7 & 1 & 20 & 351 & 0.002 \\
\hline 118 & 3 & 2 & 0 & 0 & 122 & 336 & 9 & 3 & 3 & 0 & 351 & 0.666 \\
\hline 35 & 77 & 10 & 1 & 0 & 123 & 181 & 144 & 5 & 3 & 19 & 352 & $<0.000$ \\
\hline 81 & 30 & 12 & 0 & 0 & 122 & 75 & 254 & 8 & 1 & 13 & 351 & $<0.000$ \\
\hline 87 & 20 & 14 & 2 & 0 & 123 & 206 & 117 & 8 & 2 & 20 & 353 & $<0.000$ \\
\hline 90 & 17 & 15 & 1 & 0 & 123 & 225 & 92 & 7 & 2 & 24 & 350 & $<0.000$ \\
\hline 102 & 17 & 2 & 1 & 0 & 123 & 219 & 91 & 11 & 11 & 11 & 343 & 0.001 \\
\hline 109 & 6 & 8 & 2 & 0 & 122 & 231 & 87 & 8 & 2 & 20 & 348 & $<0.000$ \\
\hline 107 & 6 & 8 & 2 & 0 & 122 & 291 & 20 & 8 & 1 & 32 & 352 & 0.001 \\
\hline 46 & 53 & 22 & 2 & 0 & 122 & 105 & 208 & 8 & 2 & 28 & 351 & $<0.000$ \\
\hline 116 & 4 & 2 & 0 & 0 & 123 & 259 & 47 & 12 & 24 & 5 & 347 & $<0.000$ \\
\hline
\end{tabular}




\section{APPENDIX D CHANGES TO BOARD ACTIVITY WHEN COMPANY IS UNDER FINANCIAL STRESS}

\section{Table 44}

Changes in director expectations based on financial state of corporation

Trading normally

Where necessary replacing senior executives

Reviewing and guiding risk policy

Communicating with external stakeholders

Ensuring the company meets its financial obligations

Ensuring the company complies with its legal obligations

Setting company performance objectives

Ensuring clear lines of accountability throughout the

organisation

Setting annual budgets

Where necessary replacing CEO

Reporting to shareholders

Setting company strategy

Overseeing the work of the auditors

Approving related party transactions

Approving major investment expenditure

Setting occupational health and safety policy
Trading under financial stress

\begin{tabular}{|c|c|c|c|c|c|c|c|c|c|c|}
\hline Board & $\begin{array}{r}\text { Manage } \\
\text { ment }\end{array}$ & Both & $\begin{array}{l}\text { No } \\
\text { Pref }\end{array}$ & $\begin{array}{r}\text { Sample } \\
\text { size }\end{array}$ & Board & $\begin{array}{r}\text { Manage } \\
\text { ment }\end{array}$ & Both & $\begin{array}{l}\text { No } \\
\text { Pref }\end{array}$ & $\begin{array}{r}\text { Sample } \\
\text { size }\end{array}$ & $\begin{array}{r}\text { P } \\
\text { Value }\end{array}$ \\
\hline 7 & 113 & 8 & 0 & 128 & 35 & 77 & 10 & 1 & 123 & $<0.001$ \\
\hline 106 & 12 & 8 & 2 & 128 & 109 & 6 & 8 & 0 & 123 & $<0.001$ \\
\hline 5 & 111 & 11 & 1 & 128 & 46 & 53 & 22 & 2 & 123 & $<0.001$ \\
\hline 65 & 45 & 16 & 2 & 128 & 90 & 17 & 15 & 1 & 123 & 0.001 \\
\hline 62 & 44 & 21 & 1 & 128 & 87 & 20 & 14 & 2 & 123 & 0.002 \\
\hline 85 & 26 & 17 & 0 & 128 & 98 & 9 & 15 & 0 & 122 & 0.010 \\
\hline 41 & 74 & 11 & 0 & 126 & 64 & 50 & 8 & 1 & 123 & 0.011 \\
\hline 53 & 59 & 16 & 0 & 128 & 69 & 40 & 13 & 0 & 122 & 0.052 \\
\hline 124 & 3 & 0 & 0 & 127 & 118 & 3 & 2 & 0 & 123 & 0.353 \\
\hline 103 & 9 & 14 & 2 & 128 & 107 & 6 & 8 & 2 & 123 & 0.529 \\
\hline 100 & 11 & 17 & 0 & 128 & 99 & 7 & 16 & 1 & 123 & 0.609 \\
\hline 97 & 24 & 3 & 2 & 126 & 102 & 17 & 2 & 1 & 122 & 0.617 \\
\hline 117 & 7 & 3 & 0 & 127 & 116 & 4 & 2 & 0 & 122 & 0.631 \\
\hline 115 & 7 & 3 & 2 & 127 & 115 & 4 & 2 & 1 & 122 & 0.741 \\
\hline 85 & 29 & 14 & 0 & 128 & 81 & 30 & 12 & 0 & 123 & 0.920 \\
\hline
\end{tabular}




\section{Table 45}

Changes in shareholder expectations based on financial state of corporation

Trading normally

Trading under financial stress

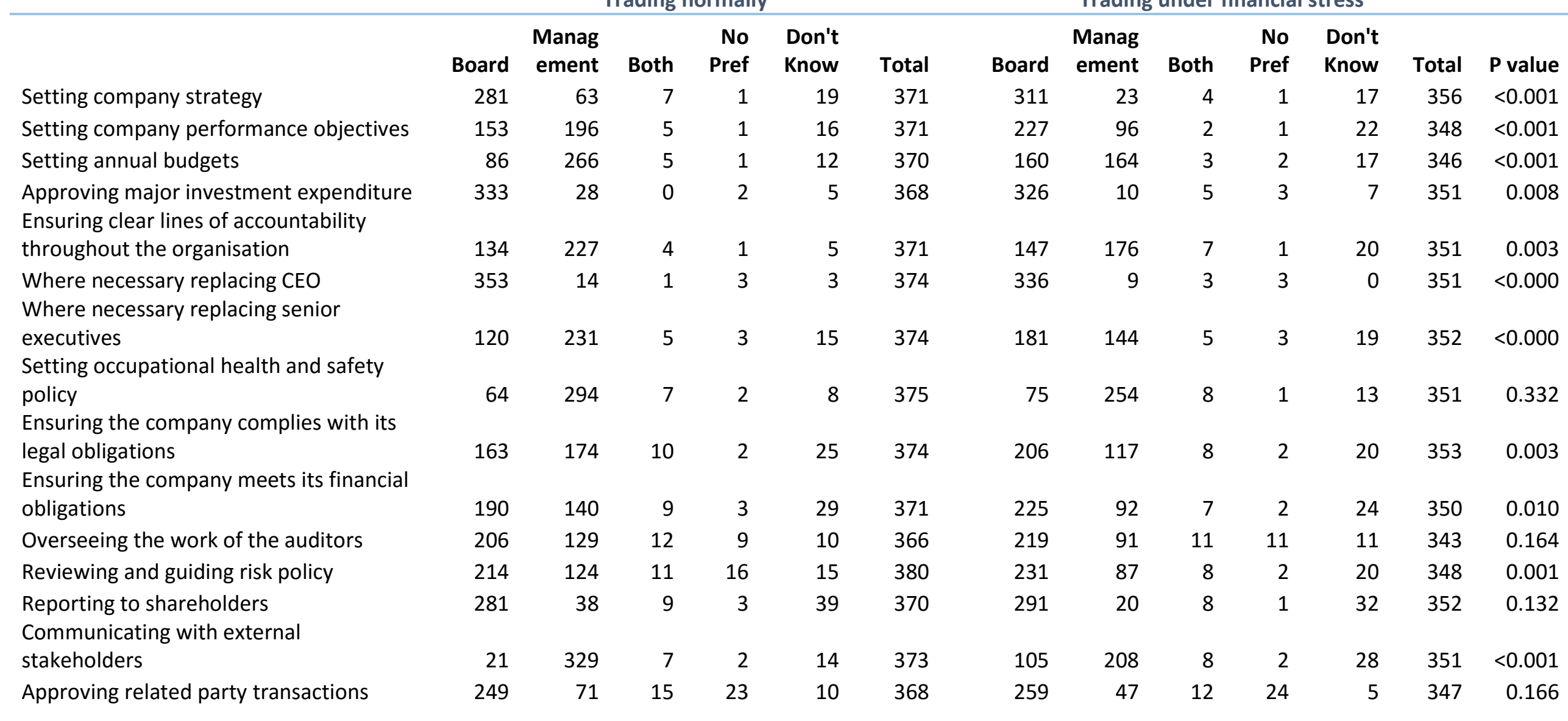

